Prepared in cooperation with the Nebraska Department of Roads

\title{
Peak-Flow Frequency Relations and Evaluation of the Peak-Flow Gaging Network in Nebraska
}

Water-Resources Investigations Report 99-4032 
U.S. Department of the Interior

U.S. Geological Survey

\section{Peak-Flow Frequency Relations and Evaluation of the Peak-Flow Gaging Network in Nebraska}

By Philip J. Soenksen, Lisa D. Miller, Jennifer B. Sharpe, and Jason R. Watton

Water-Resources Investigations Report 99-4032

Prepared in cooperation with the Nebraska Department of Roads 


\title{
U.S. DEPARTMENT OF THE INTERIOR
}

Bruce Babbitt, Secretary

\section{U.S. GEOLOGICAL SURVEY}

Charles G. Groat, Director

\begin{abstract}
Any use of trade, product, or firm names in this publication is for descriptive purposes only and does not imply endorsement by the U.S. Government.
\end{abstract}

Lincoln, Nebraska, 1999

For additional information write to:

District Chief

U.S. Geological Survey, WRD

406 Federal Building

100 Centennial Mall North

Lincoln, NE 68506

Copies of this report can be purchased from:

U.S. Geological Survey

Branch of Information Services

Box 25286

Denver, CO 80225 


\section{CONTENTS}

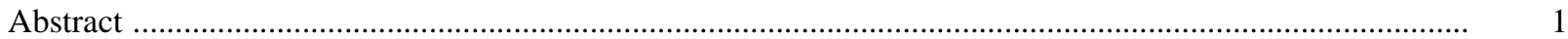

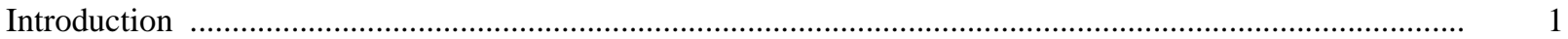

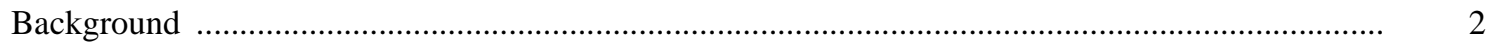

Purpose and Scope ………...................................................................................................

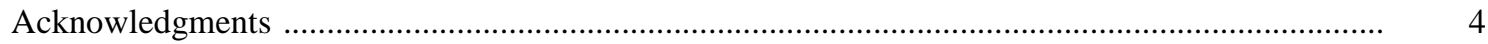

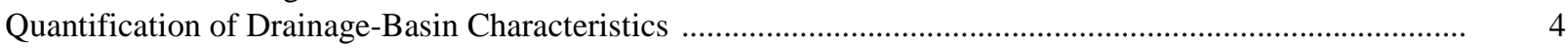

Morphometric Characteristics .................................................................................................

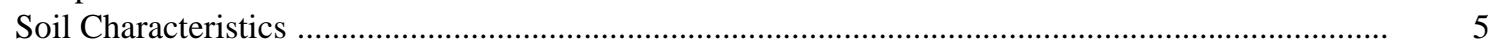

Precipitation Characteristics ................................................................................... 5

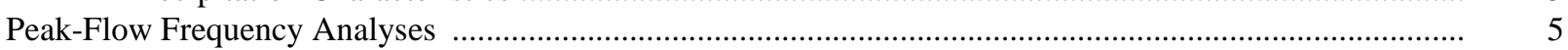

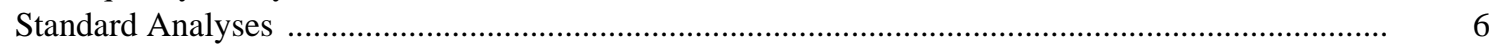

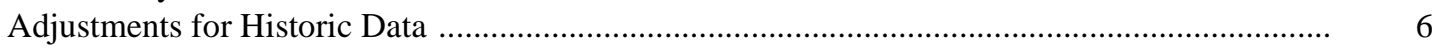

Adjustments for High and Low Outliers ............................................................................... 6

Generalized Skew Coefficients....................................................................................... 7

High-Permeability Regional Skew Equation .................................................................... 9

Northern and Western Regional Skew Equation ........................................................... $\quad 10$

Northeastern Regional Skew Equation ..................................................................... $\quad 10$

Southeastern Regional Skew Equation ....................................................................... 12

Low-Permeability Skew Map .................................................................................. 12

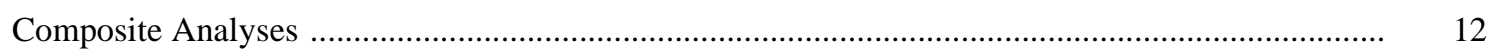

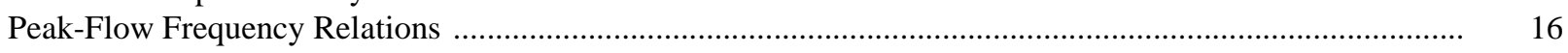

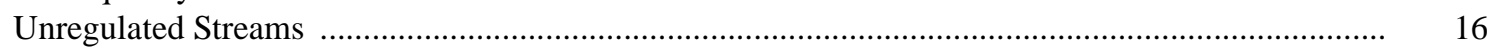

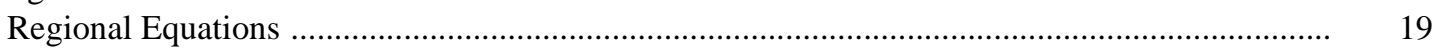

High Permeability Region ................................................................................. 21

Northern and Western Region ................................................................................. 23

Northeastern Region .......................................................................................... 24

Central and South-Central Region ............................................................................ 25

Eastern Region ........................................................................................ 26

Upper Republican River Region ............................................................................. 27

Big Blue River Region .......................................................................................... 28

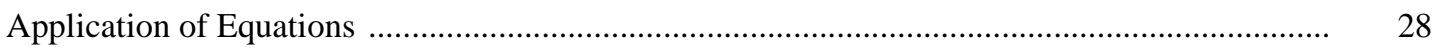

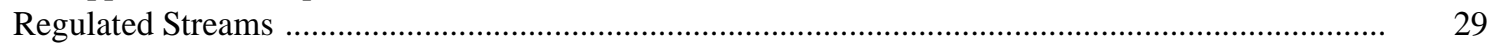

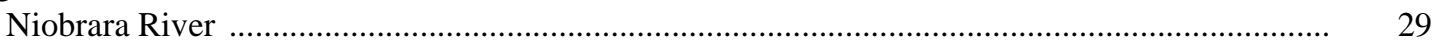

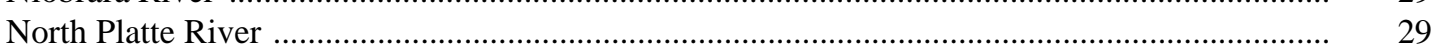

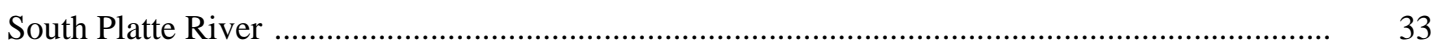

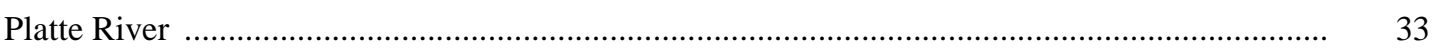

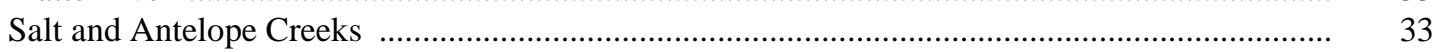

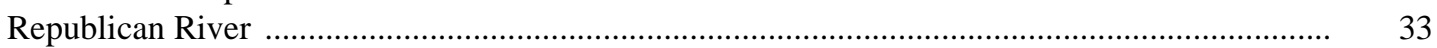

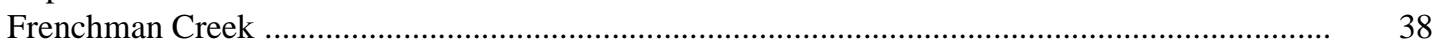

Red Willow Creek ........................................................................................................ 38

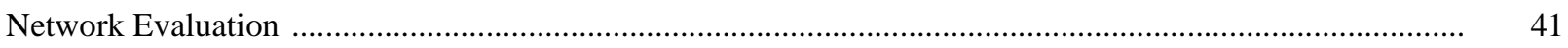

Station Selection .................................................................................................................

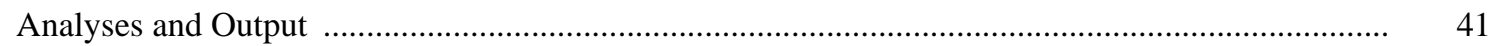

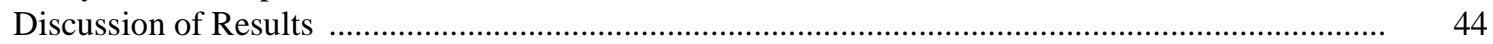

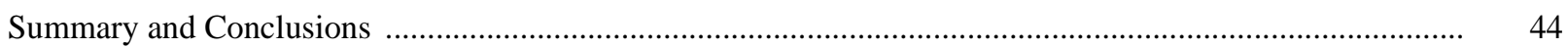

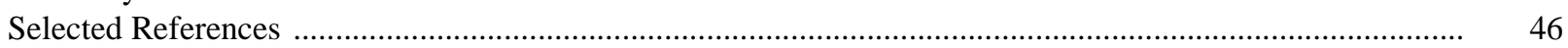




\section{CONTENTS--Continued}

Appendixes

A-Descriptions of Selected Drainage-Basin Characteristics Quantified Using Basinsoft,

ARC-INFO, and Related GIS Programs

Morphometric Characteristics

Modifications to Basinsoft

Areal-Size Quantifications

Linear-Size Quantifications

A-2

Shape Quantifications

A-2

Relief Quantifications

A-2

Relief Quantifications

A-2

Aspect Quantification

A-3

Stream-Network Quantifications

A-3

Relief-Stream Network Quantifications

Soil Characteristics

A-3

Precipitation Characteristics

A-4

B-Tables of Drainage-Basin Characteristics and Peak-Flow Frequency Data

B-1

C-Graphs of Composite Peak-Flow Frequency Curves for Selected Stations

C-1

\section{Figures}

1-3. Maps showing:

1. Selected streams and dams, and areas with sandhills in Nebraska and parts of adjacent states......

2. Location of streamflow-gaging stations in Nebraska and adjacent states used to develop generalized skew coefficient relations for log-Pearson Type III peak-flowfrequency analyses.

3. Regions of generalized skew-coefficient equations for Nebraska, and distribution of generalized skew-coefficients for basins with average permeability of the top 60 inches of soil (P60) of less than 4 inches per hour but including the entire Elkhorn River Basin

4. Graphs showing peak-flow frequency curves and daily discharge lag plots for three Nebraska streamflow-gaging stations

5. Graphs showing four examples of Nebraska streamflow-gaging stations requiring composite frequency curves because of apparent mixed populations of data that are not caused by basins with large proportions of noncontributing drainage area or by average permeability of the top 60 inches of more than 4 inches per hour

6-9. Maps showing:

6. Location of streamflow-gaging stations in Nebraska and selected stations in adjacent states with at least 10 years of unregulated peak-flow record

7. Location of streamflow-gaging stations in Nebraska and selected stations in adjacent states with at least 10 years of regulated peak-flow record

8. Hydrologic regions in Nebraska for unregulated peak-flow frequency equations

9. Location of flood-control dams in the Salt Creek drainage basin and of streamflow-gaging stations along the mainstem of Salt Creek

10-18. Graphs showing:

10. Peak-flow frequencies for the current regulated condition of the Niobrara River in Nebraska estimated from streamflow-gaging station data

11. Peak-flow frequencies for the current regulated condition of the North Platte River in Nebraska estimated from streamflow-gaging station data 


\section{CONTENTS--Continued}

12. Peak-flow frequencies for the current regulated condition of the South Platte River in Nebraska and part of Colorado estimated from streamflow-gaging station data ....

3. Peak-flow frequencies for the current regulated condition of the Platte River in Nebraska estimated from streamflow-gaging station data

14. Peak-flow frequencies for the current regulated conditions of Salt and Antelope Creeks in Lancaster, Cass, and Saunders Counties of Nebraska estimated from streamflow-gaging station data

15. Peak-flow frequencies for the current regulated condition of the Republican River in Nebraska and part of Kansas estimated from streamflow-gaging data

16. Peak-flow frequencies for the current regulated conditions of Frenchman and Red Willow Creeks in Nebraska estimated from streamflow-gaging station data....

17. Results of network analyses for 10- and 20-year planning horizons for High-PermeabilityStandard, High Permeability-Composite, Northern and Western, and Northeastern regional 100-year peak-flow-frequency equations....

18. Results of network analyses for 10- and 20-year planning horizons for Central and South-Central, Eastern, Upper Republican River, and Big Blue River regional 100-year peak-flow frequency equations.

A1-A3. Maps showing:

A1. Maximum expected precipitation for Nebraska and parts of adjacent state, for a duration of 24 hours and a recurrence interval of 2 years

A2. Thiessen polygons of mean annual precipitation for National Oceanic and Atmospheric Administration and National Weather Service rain gages in Nebraska and parts of adjacent states for the period 1961-90

A3. Average permeability of the 60 -inch soil profile for Nebraska and parts of adjacent states ........

C1-C4. Graphs showing:

C1. Composite peak-flow frequency curves for selected Nebraska and South Dakota streamflow-gaging stations in the White and Niobrara River Basins with average soil permeability of the top 60 inches of more than 4 inches per hour

C2. Composite peak-flow frequency curves for selected Nebraska streamflow-gaging stations in the North Platte and Platte River Basins with average soil permeability of the top 60 inchesof more than 4 inches per hour

C3. Composite peak-flow frequency curves for selected Nebraska streamflow-gaging stations in the Platte River Basin with average soil permeability of the top 60 inches of more than 4 inches per hour

C4. Composite peak-flow frequency curves for selected Nebraska streamflow-gaging stations in the Republican River Basin with average soil permeability of the top 60 inches of more than 4 inches per hour.

Tables

1. Generalized skew equations

2-8. Peak-flow equations for the:

2. High-Permeability Region.....

3. Northern and Western Region

4. Northeastern Region

5. Central and South-Central Region

6. Eastern Region 


\section{CONTENTS--Continued}

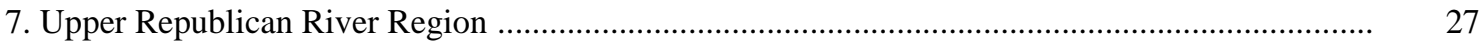

8. Big Blue River Region ...................................................................................................... 28

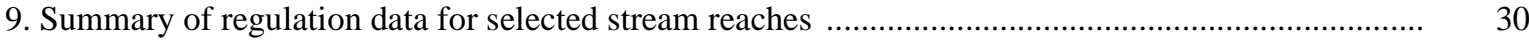

B1. Selected drainage-basin characteristics for streamflow-gaging stations in Nebraska and for selected out-of-state stations

B2. Peak-flow frequency data for streamflow-gaging stations in Nebraska and for selected out-of-state stations, and drainage areas for regulated streams

\begin{tabular}{rll}
\hline Multiply & By & To obtain \\
\hline inch (in.) & 2.54 & centimeter \\
inch (in.) & 25.4 & millimeter \\
foot $(\mathrm{ft})$ & 0.3048 & meter \\
mile $(\mathrm{mi})$ & 1.609 & kilometer \\
square kilometer & meter per mile \\
square mile $\left(\mathrm{mi}^{2}\right)$ & 2.590 & cubic meter per second \\
cubic foot per second $\left(\mathrm{ft}{ }^{3} / \mathrm{s}\right)$ & 0.3048 & meter per hour \\
\hline
\end{tabular}




\title{
Peak-Flow Frequency Relations and Evaluation of the Peak-Flow Gaging Network in Nebraska
}

\author{
By Philip J. Soenksen, Lisa D. Miller, Jennifer B. Sharpe, and Jason R. Watton
}

\section{ABSTRACT}

Estimates of peak-flow magnitude and frequency are required for the efficient design of structures that convey flood flows or occupy floodways, such as bridges, culverts, and roads. The U.S. Geological Survey, in cooperation with the Nebraska Department of Roads, conducted a study to update peak-flow frequency analyses for selected streamflow-gaging stations, develop a new set of peak-flow frequency relations for ungaged streams, and evaluate the peak-flow gaging-station network for Nebraska. Data from stations located in or within about 50 miles of Nebraska were analyzed using guidelines of the Interagency Advisory Committee on Water Data in Bulletin 17B. New generalized skew relations were developed for use in frequency analyses of unregulated streams. Thirty-three drainage-basin characteristics related to morphology, soils, and precipitation were quantified using a geographic information system, related computer programs, and digital spatial data.

For unregulated streams, eight sets of regional regression equations relating drainage-basin to peakflow characteristics were developed for seven regions of the state using a generalized least squares procedure. Two sets of regional peak-flow frequency equations were developed for basins with average soil permeability greater than 4 inches per hour, and six sets of equations were developed for specific geographic areas, usually based on drainage-basin boundaries. Standard errors of estimate for the 100-year frequency equations (1percent probability) ranged from 12.1 to 63.8 percent. For regulated reaches of nine streams, graphs of peak flow for standard frequencies and distance upstream of the mouth were estimated.
The regional networks of streamflow-gaging stations on unregulated streams were analyzed to evaluate how additional data might affect the average sampling errors of the newly developed peak-flow equations for the 100-year frequency occurrence. Results indicated that data from new stations, rather than more data from existing stations, probably would produce the greatest reduction in average sampling errors of the equations.

\section{INTRODUCTION}

Estimates of peak-flow magnitude and frequency are required for the efficient design of structures that convey flood flows, such as bridges and culverts, or of structures that occupy floodways, such as roads. In the fall of 1994, a 4-year cooperative study was begun by the Nebraska Department of Roads and the U.S. Geological Survey (USGS) to update the methods for making these estimates. Objectives of the study included (1) updating of the peak-flow frequency analyses for selected streamflow-gaging stations, (2) development of a new set of regional peak-flow frequency relations for ungaged streams, and (3) evaluation of the peakflow gaging-station network for Nebraska.

A number of new technologies had recently become available that made improvements in the peak-flow relations possible. New computer programs and procedures had been developed by the USGS for analyzing peak-flow frequency data for gaging stations. A geographic information system (GIS) and digital data could be used to compute drainage-basin characteristics that previously were undefined because they were too difficult or timeconsuming to compute manually. For relating drainage-basin characteristics to peak-flow charac- 
teristics, a generalized least squares (GLS) regression program was available that could adjust for differences in record length and flow variance, and for cross-correlations among gaging stations. A companion network-analysis program (NET) also was available that could use the output from the GLS program to evaluate how the addition of new data from existing or new peak-flow gaging stations might reduce the average sampling errors of any newly developed peak-flow frequency equations. These two programs were available together as GLSNET from Gary Tasker (USGS, written commun., 1995).

\section{Background}

Several methods of computing peak flows for selected frequencies of occurrence had been developed previously by the USGS and others for Nebraska. Furness (1955) presented a method for computing peak flows up to the 50-year frequency (recurrence interval or probability) for two regions in Nebraska. The equations were considered applicable to sites with at least $100 \mathrm{mi}^{2}$ of drainage area.

Beckman and Hutchison (1962) presented a method for computing peak flows up to the 100 -year recurrence interval for sites with less than $300 \mathrm{mi}^{2}$ of drainage area. There are 10 hydrologic areas within two regions for this method. Patterson (1966) and Matthai (1968) developed methods for sections of Nebraska as part of regional studies on the Missouri River Basin. All of the above are index-flood methods; they use a dimensionless frequency curve and a relation for predicting the mean-annual flood from hydrologic characteristics to estimate a frequency curve for any location in a region. Beckman (1976) used multiple-regression techniques to develop regional equations for peak flows up to the 100-year recurrence interval. Basin characteristics were used as the explanatory variables in the five sets of regional equations.

Cordes (1993) updated Beckman's (1976) equations based on additional data and the new floodflow frequency guidelines of Bulletin 17B (Interagency Advisory Committee on Water Data, 1982). He developed a generalized skew coefficient map (of base-10 logarithms of annual maximum peak flows) for Nebraska and included several new explanatory variables in the regional regression analyses of peakflow frequencies. However, no new hydrologic regions were developed, and no adjustments were made to the default frequency analyses for individual stations (Rollin Hotchkiss, University of NebraskaLincoln, oral commun., 1997). The mean-square errors (MSEs) for the updated equations, as reported by Cordes (1993, p. 70), apparently were based on natural logarithms (Rollin Hotchkiss, University of Nebraska-Lincoln, oral commun., 1998). The MSEs were converted to standard errors of estimate (SEEs), in natural logarithms, by taking the square root of the values; those values then were converted to SEEs, in percent, using tabled values from Tasker (1978, p. 87). A comparison of SEEs, in percent, for corresponding equations shows that SEEs are smaller, in all cases, for the Beckman (1976) equations than for the Cordes (1993) equations. Therefore, newly developed equations in this report are compared only to the Beckman (1976) equations.

Experience has shown that the Bulletin 17B default low-outlier tests are not well suited for detecting multiple low outliers and that the log-Pearson Type III (LP3) distribution recommended by Bulletin 17B is sensitive to high outliers. The treatment of outliers can have substantial effects on peak-flow analyses, including skew coefficients from which a generalized skew-coefficient map is developed.

As part of this study, annual peak-flow data for Nebraska were compiled, checked, and published by Boohar and Provaznik (1996). Provaznik also investigated L-moments and several frequency distributions as possible alternatives to the methods recommended in Bulletin 17B. Results of the L-moment investigation can be found in Provaznik (1997), and Provaznik and Hotchkiss (1998).

\section{Purpose and Scope}

The purposes of this report are to: (1) present updated peak-flow frequency analyses for selected streamflow-gaging stations in Nebraska; (2) present and describe the development of new methods to estimate peak flows for selected frequencies for ungaged streams in Nebraska; and (3) present an evaluation of the peak-flow gaging-station network in Nebraska. Peak-flow frequency analyses and the network analyses were done for streamflow-gaging stations in or within about 50 miles of Nebraska (fig. 1). 


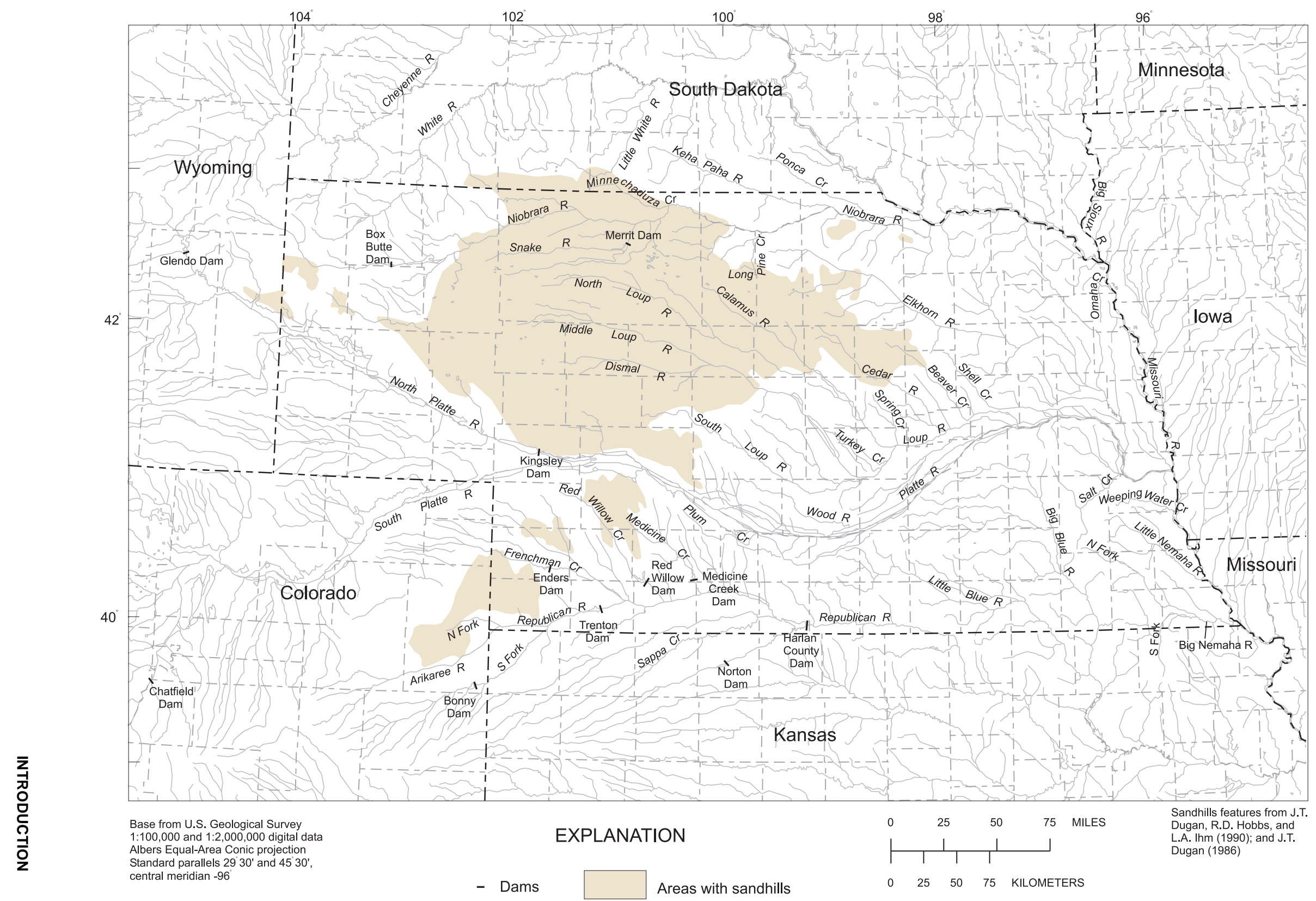

$\omega$

Figure 1. Selected streams and dams, and areas with sandhills in Nebraska and parts of adjacent states. 


\section{Acknowledgments}

The authors acknowledge Milo Cress of the Federal Highway Administration for his support in initiating this study, and the dedicated USGS student employees who spent many hours digitizing drainage-basin data layers and computing basin characteristics with GIS programs: Christopher P. Stanton, David L. Rus, Cody L. Knutson, John T. Shulters, and Mary Kay Provaznik.

\section{QUANTIFICATION OF DRAINAGE-BASIN CHARACTERISTICS}

Morphometric, soil, and precipitation drainagebasin characteristics were determined for streamflow-gaging stations having 10 or more years of record in Nebraska and for selected stations outside of Nebraska. Most of the out-of-state stations had 25 years of record and had basin centroids within 50 miles of Nebraska; however, some stations had as few as 18 years of record or were as far away as about 80 miles. GIS-related programs and procedures were used or modified to quantify drainage-basin characteristics from digital data layers of basin boundaries, elevations, streams, soil, and precipitation.

\section{Morphometric Characteristics}

Twenty-seven drainage-basin characteristics were quantified using a modified version of Basinsoft (Harvey and Eash, 1996), a computer program developed by the USGS (Majure and Soenksen, 1991; and Eash, 1994). These morphometric characteristics generally describe the form and structure of a drainage basin and its drainage network, including measurements of area, length, relief, aspect, and stream order (appendix A and table B1). Four sourcedata layers, representing the surface-water drainage divide (basin boundary), hydrography (stream network), hypsography (elevation contours), and a lattice elevation model of the drainage basin, were required to run Basinsoft.

Existing data layers of drainage-basin boundaries for gaging stations were obtained from the Nebraska Natural Resources Commission and the Iowa City, Iowa, office of the USGS. Boundaries for Nebraska basins had been delineated using 1:24,000-scale USGS topographic maps; those for Iowa basins had been delineated using 1:250,000-scale USGS topographic maps. The remaining basin boundaries for Nebraska and surrounding states were delineated on 1:250,000-scale USGS maps and digitized manually to produce GIS digital data layers. Because of the difficulty in delineating noncontributing drainage area $(N C D A)$ over the large sandhills areas of Nebraska (fig. 1), basin-characteristic measurements were made over the total drainage area (TDA) rather than over the contributing drainage area $(C D A)$. Some basin characteristics were computed from other characteristics rather than being measured directly. Characteristics that required $C D A$ in their computations were computed using published values of $C D A$.

Stream-network source-data layers were created by scanning mylar maps of 1:250,000-scale USGS hydrography data, which were converted to digital data layers using ARC/INFO version 7.0.4 (Environmental Systems Research Institute, 1996). Unfortunately, 1:250,000-scale hydrography data did not always extend to some small drainage-area basins. USGS 1:100,000 digital line graph (DLG) Quadrangle Series hydrography data were retrieved from the EROS Data Center of USGS, but these data were not used because of edge-matching problems.

Source-data layers of elevation contours and the lattice elevation model were created from 1:250,000-scale U.S. Defense Mapping Agency digital elevation model (DEM) data. GIS software was used to convert the DEM data into a lattice of point elevations and create elevation contours (Harvey and Eash, 1996). The elevation contour interval was selected to provide at least 10 contour lines per basin.

Manual topographic-map measurements of selected drainage-basin characteristics were made for 11 drainage basins in Iowa by Harvey and Eash (1996) to verify the accuracy of drainage-basin characteristics quantified using Basinsoft. Manual measurements and Basinsoft quantifications were made at identical scales. Comparison tests indicated that Basinsoft quantifications were not significantly different from manual measurements.

As an additional check of Basinsoft quantifications, manual topographic-map measurements of selected drainage-basin characteristics were made for five Nebraska drainage basins. Basinsoft quantifications did not appear to be significantly different than 
the corresponding manual measurements. Also, all TDAs determined using Basinsoft were compared with published values. Basinsoft was unable to compute basin characteristics for several stations; the reasons are not understood. These stations were not used in the development of peak-flow frequency relations for unregulated streams.

\section{Soil Characteristics}

Four drainage-basin characteristics (Dugan, 1984) that describe some aspect of the interaction of soil and water were computed from developed equations using ARC/INFO. Soil data for Nebraska and surrounding states were obtained from a digital data layer of the State Soil Geographic Data Base (STATSGO) (Natural Resources Conservation Service, 1994). The upper 60 inches of the soil profile were used to determine the majority of the soil characteristics, which include average permeability rate of the soil profiles (P60), average available water capacity of the soil profiles $(A W C)$, average permeability of the least permeable layers of the soil profile (PLP), and the average maximum soil slope (MSS) (appendix A and table B1). Manual calculations were made to verify soil characteristics for selected drainage-basins.

\section{Precipitation Characteristics}

Two drainage-basin characteristics describing expected precipitation were quantified using ARC/INFO. The 2-year (recurrence interval), 24-hour (duration) precipitation (TTP) 1-inch contours were digitized manually from Weather Bureau Technical Paper 40 (Hershfield, 1961) into a GIS digital data layer. Additionally, 0.1-inch interval contours were interpolated and digitized (fig. A1). Mean annual precipitation $(M A P)$ data compiled by the National Oceanic and Atmospheric Administration were retrieved for the period 196190 from the National Climatic Data Center Web site (URL http://www.ncdc.noaa.gov/ol/climate/online/ coop-precip.html). These data were used to create a data layer of points from which Thiessen polygons were created (fig. A2). TTP and MAP values then were determined by taking the area-weighted average of precipitation polygons coincident to the total drainage area of each basin (table B1). Manual calculations were performed to verify precipitation values for selected drainage basins.

\section{PEAK-FLOW FREQUENCY ANALYSES}

Relations between peak flows and frequency of occurrence (recurrence interval or probability of occurrence) for individual drainage basins are basic to the development of peak-flow frequency relations for larger areas. Bulletin 17B of the IACWD (Interagency Advisory Committee on Water Data, 1982) contains guidelines for the development of these basic relations using the logPearson Type III (LP3) frequency distribution. Three parameters - the mean, the standard deviation, and the skew coefficient of the logarithms of the annual maximum peak flows-are used to fit the station data to the LP3 distribution. These parameters can be thought of as the middle point, average slope, and bend or shape of a computed peak-flow frequency curve. Increasing the standard deviation or range of the peak-flow data increases the slope or steepness of the frequency curve, and decreasing the standard deviation flattens the slope of the curve. Positive skew coefficients cause the frequency curve to bend upward, negative skews cause the curve to bend downward, and zero skews produce a straight line.

For stations with unregulated (natural) streamflow, station skew coefficients of peak flows should be weighted with generalized skew coefficients for that area or for basins with similar characteristics. The assumption is that skews will be similar for stations that have similar basin characteristics or are in close proximity, and that the accuracy of the applied skew can be improved by incorporating the influence of other stations. The national map of generalized skew coefficients in Bulletin 17B provides default values for areas where local values have not been determined independently. For stations with regulated streamflow, only the station skew coefficients were used in peak-flow frequency analyses because the flow characteristics are based on imposed criteria, not on the characteristics of the drainage basins. Bulletin 17B also provides guidelines for making adjustments for historic data and low outliers. It also provides guidelines for developing composite 
peak-flow frequency relations for stations with peak flows that are produced by different runoff-producing mechanisms, such as rainfall and snowmelt.

\section{Standard Analyses}

Annual peak flows for USGS gaging stations with at least 10 years of record through 1993 and located in or within about 50 miles of Nebraska were retrieved from the USGS's national streamflow data base (Dempster, 1983). Peak-flow data were loaded into a Watershed Data Management (WDM) file (Flynn and others, 1995) and then checked and updated as necessary. Stations in the study area, but with streams that do not flow into Nebraska and with drainage areas that are mostly outside of the study area, were not used. The program PEAKFQ - an updated version of program J407 (Kirby, 1981) that utilizes WDM files - follows the guidelines of Bulletin 17B and was used for the peak-flow frequency analyses for all the gaging stations. The program outputs computed peak flows for standard exceedance probabilities (frequencies) in a tabular form and as a peak-flow frequency curve in graphical form.

Peak flows that were known to have been or could possibly have been affected to some degree by regulation-such as flood control, irrigation diversions, power generation, storage detention, or other factors-were separated from unregulated peaks before further analysis. Determinations generally were based on information from the peak-flow data base, water-data and flood-frequency reports, USGS files, topographic maps, and a statewide data base for dams, which contains location, year of completion, and amount of storage. A rough criterion was developed for estimating possible effects of regulation on peaks using a comparison of the average flow to the amount of storage in the basin. It was developed from data for stations with significant changes in storage during their periods of record by comparing changes in peak-flow frequency relations to the changes in storage for both earlier and later periods of record. The criterion was developed primarily for estimating whether the cumulative storage of numerous small dams might be affecting peaks at downstream stations. Because of the limited data upon which it was based, the criterion was used only as a guideline.

Two sets of standard peak-flow frequency analyses were computed for stations on unregulated streams. The first set of standard analyses was used to determine skew coefficients from the peak-flow data for each station. Using these station skews, several generalized skew relations then were developed. The second set of standard analyses was done using the individual station skews weighted with the newly developed generalized skews. For stations on regulated streams, one set of standard analyses was made based on station skews only. Adjustments were made to individual peak-flow frequency analyses, as appropriate, for historic data, and for high and low outliers as described in the following sections. Results of frequency analyses for peak-flow gaging stations are listed in table B2.

\section{Adjustments for Historic Data}

The number of annual peak flows, during which data were collected systematically at a gaging station (systematic record), is used in the computation of the LP3 parameters and in the determination of the plotting positions of the peak flows for the frequency curve. If one or more of the peak flows within the systematic record are known to be the largest in a period longer than the systematic record, the frequency analysis can be adjusted to this historic period. This provides a means to correct, at least partially, for the adverse effects that a very large peak flow might otherwise have on the computed peakflow frequency curve. Historic peak flows without an associated historic period cannot be added to the record being analyzed. Historic periods for peakflow data were determined primarily from the peakflow data base, but also from water-data and floodfrequency reports, USGS files, newspaper accounts of floods, and comparisons with records for other nearby stations.

\section{Adjustments for High and Low Outliers}

Extremely high or low annual peak flows that significantly depart from the trend of the rest of the data are outliers that can have a disproportionate effect on the LP3 parameters used to compute frequency curves. High outliers tend to increase both skew coefficients and standard deviations. Low outliers tend to decrease skew coefficients but increase the standard deviations. The outcome can be varied depending on the number of outliers and their values. Decreasing the skew bends the frequency curve downward and reduces expected high-end peak 
flows; increasing the standard deviation steepens the slope and increases expected high-end peak flows. Statistical tests done by the program PEAKFQ identify both high and low outliers, but adjustments cannot be made for high outliers unless historic data are available, as previously discussed. By default, any identified low outliers are eliminated (censored) by PEAKFQ and a conditional probability adjustment is made based on the assumption that the remaining values are representative of the entire period of record. Experience of the authors has shown that the statistical tests included in Bulletin 17B are not well suited for detecting multiple low outliers for many Nebraska stations. Therefore, adaptations of the existing procedure, other tests, and considerable judgment were used to identify and censor low outliers in those situations. If numerous enough, multiple low outliers can become a special case of mixed populations, as discussed later, requiring the development of composite frequency curves (see Composite Analyses).

The default PEAKFQ procedure for identifying low outliers was adapted to test other peak flows suspected of being low outliers based on a visual inspection of the default peak-flow frequency curve. The gage-base threshold can be set in PEAKFQ to isolate specific peak flows to be tested as low outliers. Peaks below the user-set gage base are not used in PEAKFQ computations, except for determining plotting positions, and a new lowoutlier threshold is computed from the remaining data. This allowed the first peak above the gage base to be tested as a low outlier against the remainder of the data. This was done in two ways: (1) by raising sequentially the gage-base threshold from the lowest flows, and (2) by setting the gagebase threshold based on breaks in the data. Data breaks were identified visually on plots of the default peak-flow frequency curves. The sequential test was used when at least one low outlier had already been identified, either by the original outlier test or by a break test. The gage-base threshold was set to the value of the largest identified low outlier and the analysis was recomputed. If a new outlier was identified, the process was repeated until no more low outliers were identified. This worked well if the low-end values were well spaced. If peak flows were grouped together below a data break, then the gage-base threshold was set to the second largest peak flow of the group, to isolate the largest peak flow below the data break, and the analysis was recomputed. Judgment was used in both of the low-outlier identification procedures when the criterion was within at least 90 percent of the peakflow value being tested.

Another low-outlier test used was to censor peak-flow values, either individually or in groups, and observe the effects on the high end of the peakflow frequency curve. This was done by setting the low-outlier criterion to the value of interest. For stations with multiple low outliers, this procedure was usually not very effective until most or all of the low outliers were censored. Considerable judgment was used with this procedure, but usually at least a 10-percent change in the 100-year frequency peak flow was required before the censored value or values were considered low outliers. For many stations, although the lower peak-flow values did not appear to be representative, there was no clearcut data break and the quantitative outlier tests were not definitive. In these cases, a visual evaluation of the fit, especially of the upper half of the peak-flow frequency curve, from which all of the peak-flow frequency values of interest were determined, was the final and overriding test of low outliers.

\section{Generalized Skew Coefficients}

Regional equations relating generalized skew coefficients (of base-10 logarithms $\left(\log _{10}\right)$ of annual maximum peak flows) to basin characteristics were developed for most of the state, and a statewide map of generalized skew coefficients for basins with relatively low soil permeability also was developed. These relations were based on frequency analyses from 224 gaging stations (fig. 2 and table B2) and the procedures given in Bulletin 17B (Interagency Advisory Committee on Water Data, 1982). The national skew coefficient map included in Bulletin 17B was developed originally for Bulletin 17 (U.S. Water Resources Council, 1976), and was based on a relatively small number of stations with minimal evaluation of low outliers, no adjustments for historic data, no identification or treatment of high outliers, and no 


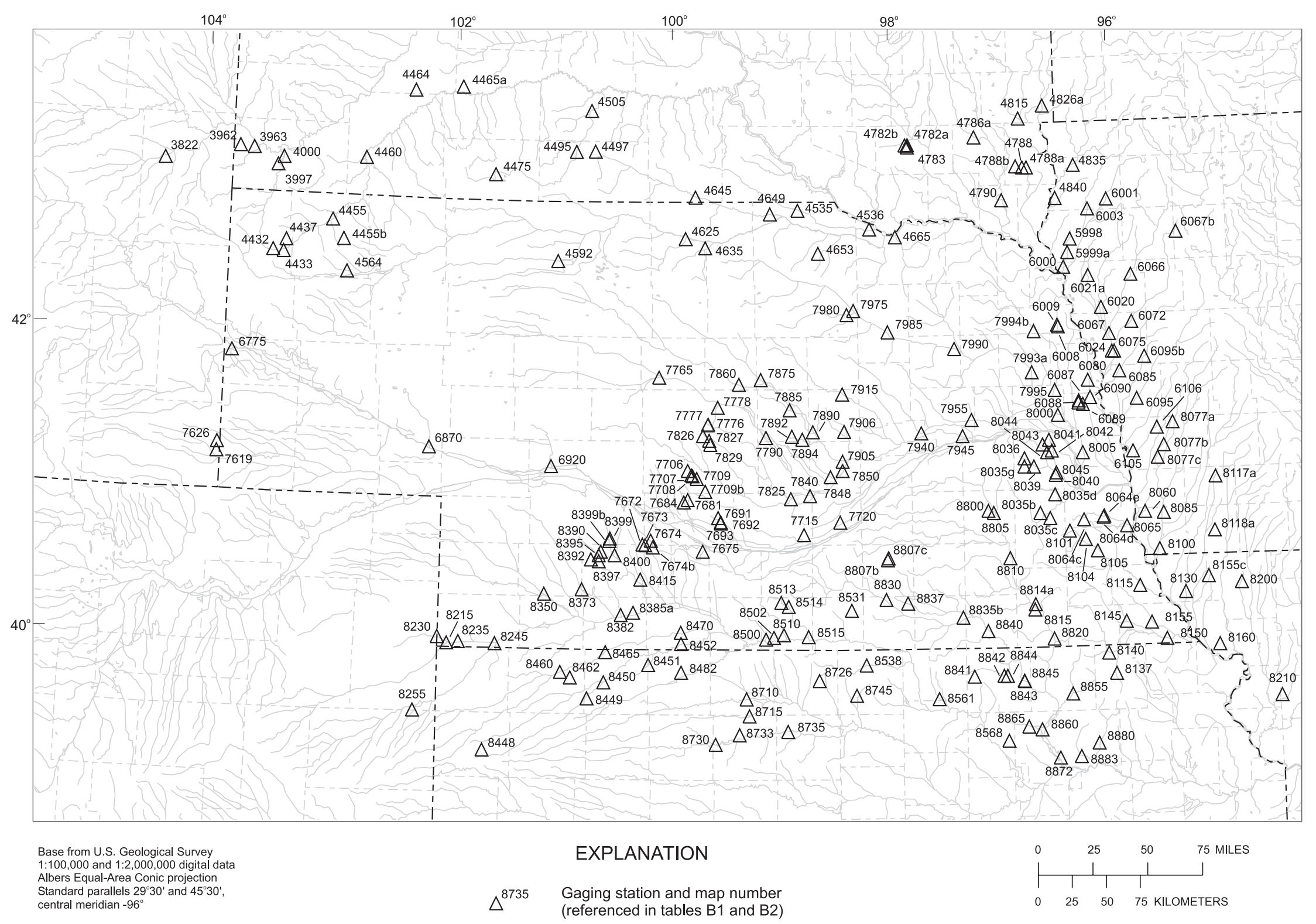

Figure 2. Location of streamflow-gaging stations in Nebraska and adjacent states used to develop generalized skew coefficient relations for log-Pearson Type III peakflow-frequency analyses. 
detailed evaluation of individual peak-flow frequency curves. In Nebraska, values shown by the national map were influenced by the high positive skews from a few stations with drainage areas mostly in the sandhills. Because the map is generalized, this influence went beyond the actual area of the sandhills.

Station skew coefficients were computed using PEAKFQ for stations in or within about 50 miles of Nebraska that, generally, had 25 years or more of unregulated peaks. Several stations with as few as 18 annual peaks were used where data were lacking. Adjustments for historic information and low outliers were made as previously described. Low outliers tend to make the station skew more negative and high outliers tend to make it more positive. Because procedures were applied to reduce the effects of low outliers in most cases, it also was considered necessary to limit the effects of high outliers, identified by PEAKFQ, to limit bias in any skew relations developed.

After other adjustments had been made to the peak-flow frequency analyses, stations with PEAKFQ high outliers were analyzed further to estimate how sensitive the station skew coefficients were to the high outliers. Using the historic adjustment procedure in PEAKFQ, high outliers for a station were assumed to be historic peaks and then the record length was doubled, tripled, and quadrupled arbitrarily. The new skew coefficients were noted and differences from the original values were computed. The skew was considered fairly stable if it did not change by more than $0.20,0.30$, or 0.40 , respectively, for sandhills stations, and by more than $0.10,0.15$, or 0.20 , respectively, for all other stations. Stations with skew changes greater than these were considered unstable because of the high outlier(s), and those stations were eliminated from further consideration in the skew relations.

Equations to predict skew coefficients were preferred to a skew map because equations eliminate the assumption that basins in close proximity have similar skew values. Rather, skews estimated using equations are based on measurable characteristics for each individual basin. It is more difficult to compute skews with equations compared to determining skews from maps because each of the explanatory variables in the equation must be measured or computed.

A skew equation first was developed for basins with average soil permeability $(P 60)$ greater than $2.5 \mathrm{in} / \mathrm{hr}$ (high-permeability regional skew equation); this eliminated the need to map the high positive skew areas of the sandhills as was done for the national map. A skew map then was developed for basins with $P 60$ less than $4 \mathrm{in} / \mathrm{hr}$, and for the entire Elkhorn River Basin (see fig. 1 for location of specific streams), which includes basins with $P 60$ greater than $4 \mathrm{in} / \mathrm{hr}$. This resulted in some overlap with the high-permeability equation. Regional equations, based mostly on geographic areas, also were developed; however, only those with mean-square errors (MSEs) less than those for the newly developed skew map were used, as recommended in Bulletin 17B. Because of the importance of $P 60$ in deciding which skew relation to use, a generalized map of P60_SS (appendix A) is presented (fig. A3). For actual measurements of $P 60$ for a drainage basin, values should be quantified using a GIS, as previously described. Using Statit statistical programs (Statware, Inc., 1990) standard multiple-regression techniques were used to develop skew estimation equations (table 1). Residuals were analyzed to define regions and to try and determine the best combination of explanatory variables. Equations were examined to ensure that they were hydrologically reasonable. The adjusted R-square, MSE, ratio of MSE to variance, and standard error of estimate (SEE) were computed from or taken from Statit output files for each equation (table 1). Regions and skew coefficients that have been defined geographically are shown in figure 3 .

\section{High-Permeability Regional Skew Equation}

The high-permeability regional skew equation is based on 38 stations with at least 25 years of record and with $P 60$ greater than $2.5 \mathrm{in} / \mathrm{hr}$, except those in the Elkhorn River Basin. The equation applies to high-permeability basins, not to a distinct geographic area. However, it is uncertain whether the equation is applicable to: right-bank tributaries of the Little White River and adjoining left-bank tributaries of the Niobrara River upstream of and including Minnechaduza Creek; and right-bank 
Table 1. Generalized skew equations

$\left[B S\right.$, basin slope, in feet per mile; $C R$, compactness ratio, dimensionless; GSkew, generalized skew coefficient of base-10 $\log _{\text {arithms }}\left(\log _{10}\right)$ of annual maximum peak flows, dimensionless; MSE, mean square error; $M S S$, average maximum soil slope, in percent; $P 60$, permeability of the 60-inch soil profile, in inches per hour; $P L P$, permeabilitiy of the least permeable layer, in inches per hour; SEE, standard error of estimate; $S R$, slope ratio of main-channel slope to basin slope, dimensionless; >, greater than]

Estimation equation

\begin{tabular}{ccc}
$\begin{array}{c}\text { Adjusted } \\
\text { R-square }\end{array}$ MSE & $\begin{array}{c}\text { Ratio of } \\
\text { MSE to } \\
\text { variance }\end{array} \quad$ SEE \\
\hline (based on $\log _{10}$ transforms of \\
peak-flow data)
\end{tabular}

High Permeability Skew Region

(38 stations with 25 or more years of record)

GSkew $=\frac{-1.261}{C R}+1.169\left(\log _{10} P 60\right)-0.112$
Northern and Western Skew Region

(31 stations with 20 or more years of record)

GSkew $=0.1716 P L P+\frac{1.216}{M S S}-\frac{0.6688}{C R}+0.109$
Northeastern Skew Region $\quad .84 \quad \begin{array}{llll}.033 & .16 & .182\end{array}$

(30 stations with 20 or more years of record)

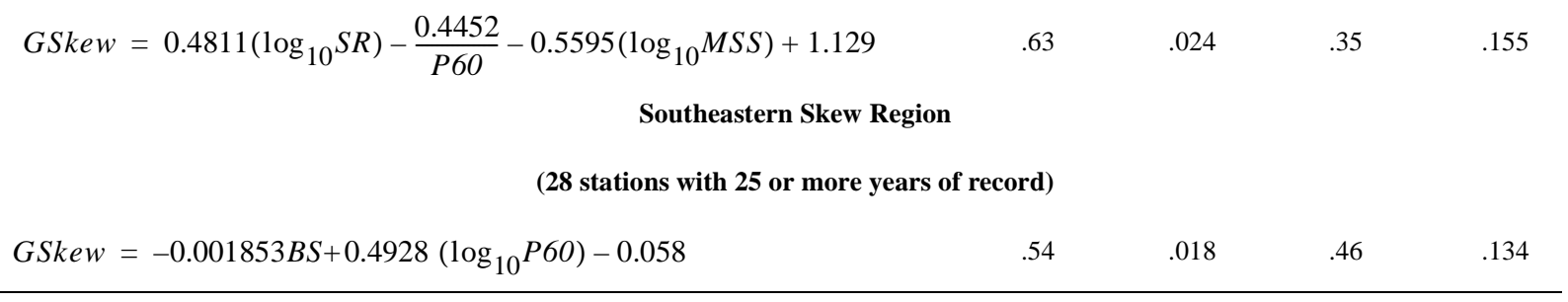

NOTE: $C R, S R$, and $B S$ are data-scale dependent.

tributaries of the Niobrara River that are adjacent to the Elkhorn River Basin (left and right banks are referenced to facing in the downstream direction). Stations from these areas were not used because of insufficient record length or problems in computing the basin characteristics. Three stations in the Little White River-Minnechaduza Creek divide area had negative skews, which were not consistent with the equation results of positive skews for stations with high permeabilities and low compactness ratios $(C R)$. Therefore, station skews were used in the peak-flow frequency analyses for this area instead of skews estimated from the equations.

\section{Northern and Western Regional Skew Equation}

The northern and western regional skew equation is based on 31 stations with at least 20 years of record, from southeastern
Wyoming, southern South Dakota, and northern and western Nebraska. Stations are in the following basins: right-bank Cheyenne River, upper White River, Little White River, Missouri River tributaries from the South Dakota-Nebraska state line to and including right-bank tributaries of the Big Sioux River, and the North and South Platte Rivers. This region (fig. 3) overlaps with the northeastern skew region and includes some stations used in the high-permeability regional skew equation.

\section{Northeastern Regional Skew Equation}

The northeastern regional skew equation is based on 30 stations with at least 20 years of record, from northeastern Nebraska, southeastern South Dakota, and northwestern Iowa. 


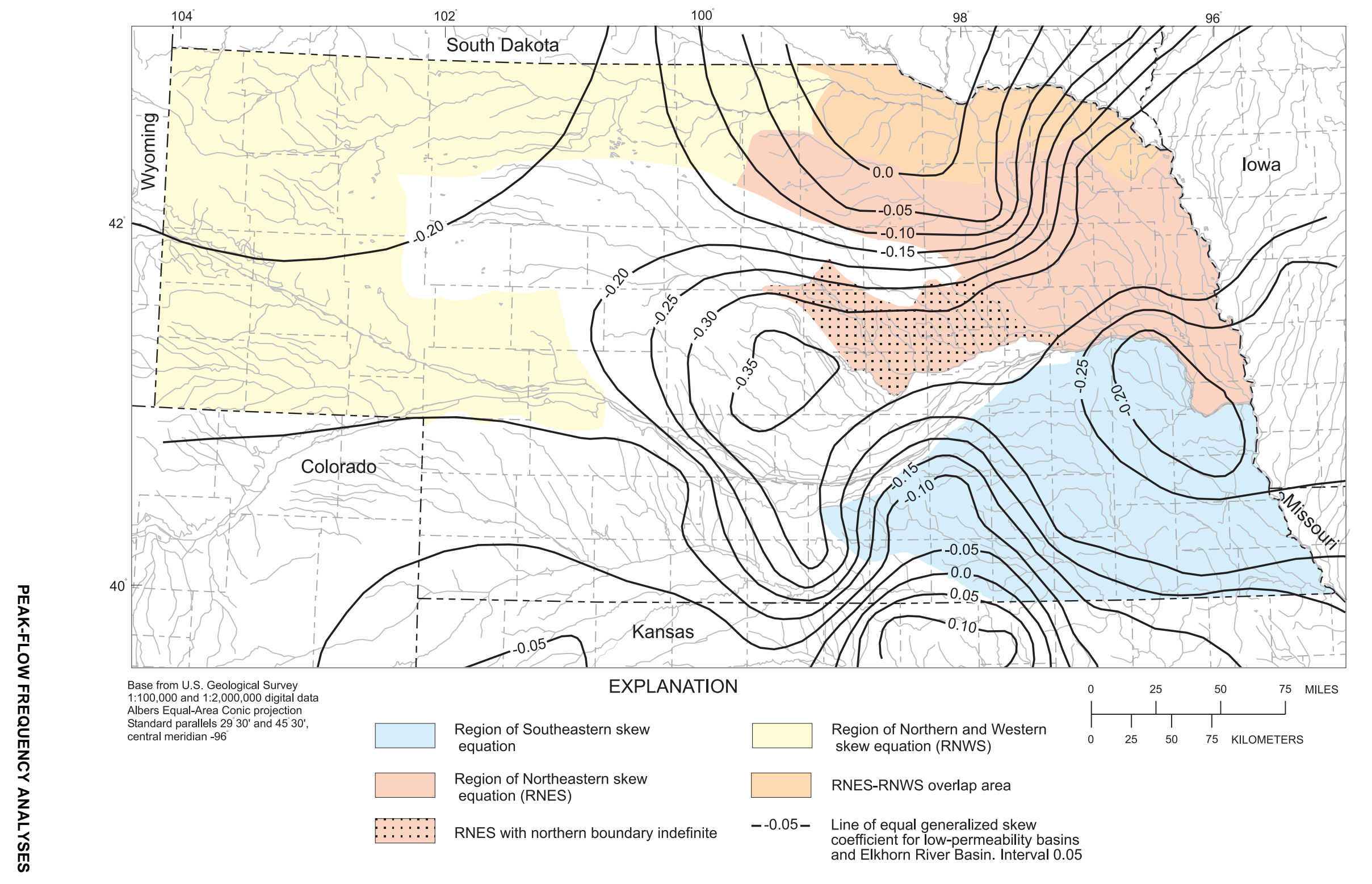

Figure 3. Regions of generalized skew-coefficient equations for Nebraska, and distribution of generalized skew-coefficients for basins with average permeability of the top 60 inches of soil $(P 60)$ of less than 4 inches per hour but including the entire Elkhorn River Basin. Coefficients are for log-Pearson Type III frequency analyses of unregulated annual peak flows. 
Stations are in the following basins: Ponca Creek, lower Niobrara River (adjacent to the Elkhorn River Basin), Missouri River tributaries from the Niobrara River to the Platte River, Middle Loup and Loup River tributaries downstream of and including Turkey Creek, Shell Creek, and the Elkhorn River. The region also is considered to include other leftbank Platte River tributaries downstream of the Loup River. This region (fig. 3) overlaps with the northern and western skew region and includes some stations used in the high-permeability regional skew equation.

\section{Southeastern Regional Skew Equation}

The southeastern regional skew equation is based on 28 Nebraska stations with at least 25 years of record, from the Salt and Weeping Water Creek Basins, the Little and Big Nemaha River Basins, and the Little and Big Blue River Basins. The region also is considered to include other right-bank tributaries of the Platte River downstream of Hydrologic Unit 10200103 (U.S. Geological Survey, 1976) (which extends several miles below the mouth of the Loup River) and of the Missouri River between the Platte River and the Nebraska-Kansas state line. The region is shown in figure 3.

\section{Low-Permeability Skew Map}

A low-permeability skew map of Nebraska (lines of equal generalized skew coefficient, fig. 3) was developed for basins with $P 60$ less than $4 \mathrm{in} / \mathrm{hr}$, and including the entire Elkhorn River Basin regardless of soil permeability. Skew values were plotted at the centroid of the drainage area for each station. The skew values were clustered geographically based on judgment with consideration given to such factors as basin similarity and apparent trends. An average skew value, weighted by the number of annual peak years for each station, was computed for each cluster. The weighted-average value then was assigned to every point in the cluster. Lines of equal skew coefficient initially were determined using a contouring program and were revised manually using judgement. Differences between the lines and the actual station skew values were determined and the MSE was computed by summing the squares of the differences and dividing by the total number of stations used. Several clustering schemes were used in an attempt to minimize the MSE while still keeping the lines general enough to represent broad trends. The map became more general as the number of clusters was reduced; a single cluster would result in an overall average skew for the state. The final map (fig. 3) is based on 189 stations and has an MSE of
0.052 and a SEE of 0.24. The skew map in

Bulletin 17B has a standard deviation (computed the same as the SEE reported here) of 0.55 , but this is not comparable because it is for the whole country. Cordes (1993, p. 59-60) reports that the standard deviation is 0.78 for the Nebraska part of the national map in Bulletin 17B. The skew map for Nebraska presented by Cordes, which includes the high-permeability sandhills areas, as was done for the national map, has a standard deviation of 0.59 .

\section{Composite Analyses}

Using a conditional probability method suggested by William Kirby (USGS) (Wilbert Thomas, Jr., USGS, written commun., 1995), an alternative set of frequency analyses were computed for selected high-permeability stations that apparently have two different populations of annual peak flows in the data. A pattern that showed different flow characteristics for the largest peaks seemed apparent from the initial peak-flow frequency curves for most of the high-permeability stations. Because sandhills terrain typically includes large areas of noncontributing drainage and high permeability, it was theorized that most of the lower-flow peaks consisted primarily of interflow and baseflow and that the higher-flow peaks had a significantly greater proportion of surface runoff than the lower-flow peaks.

Unit-value flow data were not readily available for using a flow-hydrograph separation technique to test the theory. Therefore, plots of peak flow versus the lower of the 1- or 2-day lag of daily flow were made for several stations to determine if the theory was at least plausible. Three such plots, along with their respective peak-flow frequency plots, are shown in figure 4 . The results are not definitive because daily value data are so generalized compared to unit value data (commonly 15 -minute intervals) and true recessions are not always apparent, especially if secondary peaks are masked within the daily values. Even so, there is a general tendency for the higher flows to have a greater proportionate drop-off in flow than do the lower flows. This supports the theory because flows with proportionately more surface runoff than interflow or baseflow would have steeper recessions for a given station. Based on the 

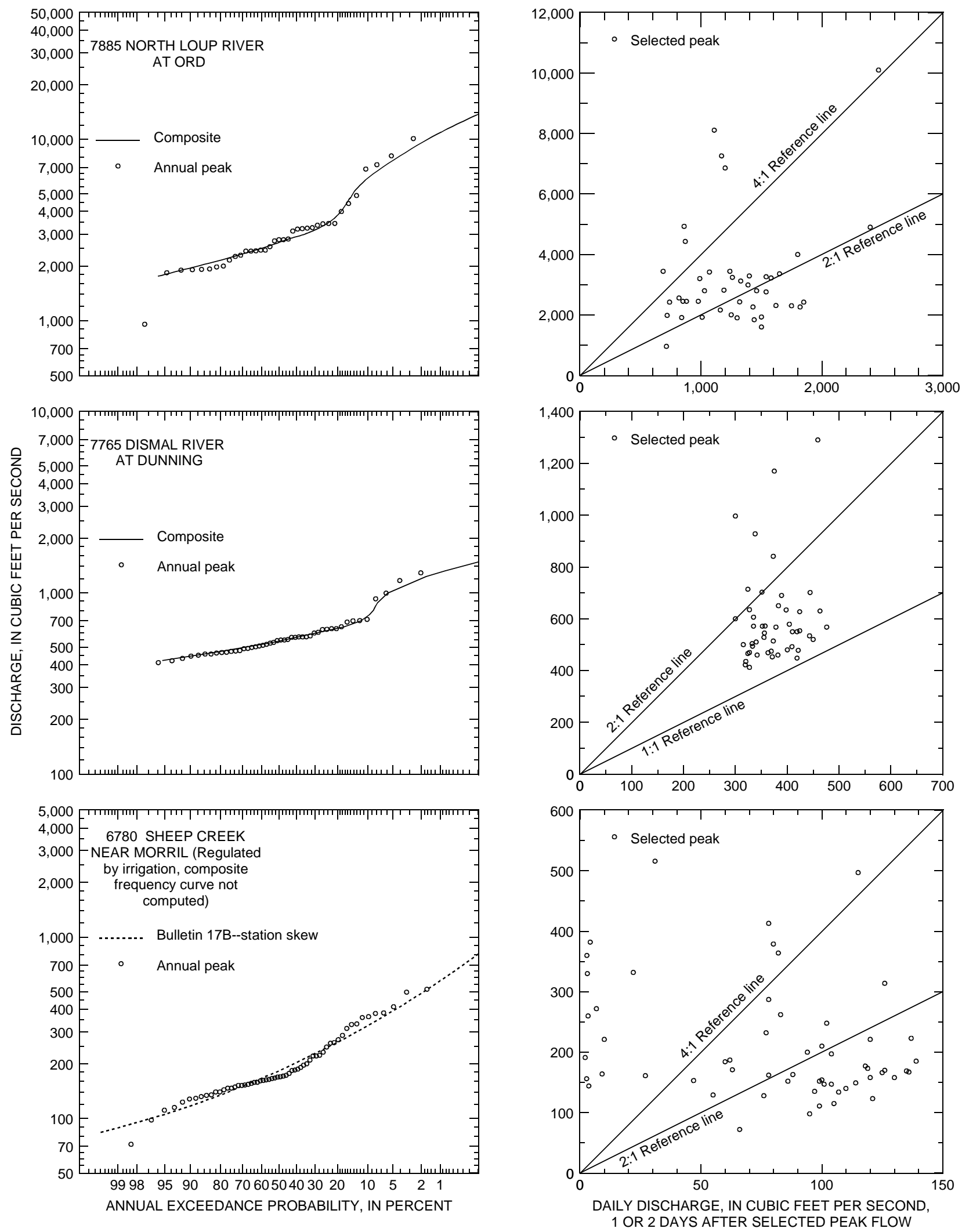

Figure 4. Peak-flow frequency curves and daily discharge lag plots for three Nebraska streamflow-gaging stations. 
observed patterns in the peak-flow frequency plots and the lag plots, it was decided to treat the peak flows above and below the breaks on the peak-flow frequency plots as two different populations, or regimes, of flow for an alternative set of frequency analyses.

Kirby's method of developing a composite peak-flow frequency curve for a station requires that there be enough annual peaks of each flow regime to compute separate frequency curves. PEAKFQ requires at least three peaks to make a computation. Peak-flow values for the selected stations were separated into higher- and lower-flow regimes and loaded into special WDM files. Because there were no generalized skew relations established for these situations, analyses were computed with PEAKFQ using station skews only. The use of zero skews or weighted skews might have been preferable in some situations to limit the effects of outliers on curves with already limited data. The results from the individual analyses were combined using conditional probabilities as shown in Kirby's equation modified from Thomas (Wilbert Thomas, Jr., USGS, written commun., 1995):

$$
P(F>x)=\begin{gathered}
{[P(F>x \backslash \mathrm{F} \in H) \times P(F \in H)]+} \\
{[P(F>x \backslash F \in L) \times P(F \in L)]}
\end{gathered}
$$

where: $P=$ probability that

$$
F=\text { annual maximum peak flow }
$$

$x=$ given value of peak flow

$\backslash$ = given that

$F \in H=$ annual maximum peak flow is a higher-regime flow

$F \in L=$ annual maximum peak flow is a lowerregime flow

Composite peak-flow frequency curves were plotted and peak flows for the standard exceedance probabilities were determined visually from the graphs. This was done for 22 high-permeability (P60 greater than $4 \mathrm{in} / \mathrm{hr}$ ) stations with unregulated flows (fig. 4 and figs. $\mathrm{C} 1$ to $\mathrm{C} 4$ ).

Other types of mixed populations in station data also were apparent, including stations with relatively low permeability and precipitation-especially in northwestern Nebraska-and stations on partially regulated streams. The thorough investigations required to split the data and to do the analyses of all of these other cases were beyond the scope of this study. Low-permeability stations with apparent mixed populations were dropped from the regional analyses of peak-flow frequency but are listed with appropriate notes in table B2. Preliminary composite analyses were done for several Platte River stations, including Platte River at Brady (7660) (fig. 5).

However, most stations on partially regulated streams were simply computed with station skews and, where mixed populations appeared to be most apparent, notes were included in the appropriate figures and tables.

In the more arid areas of Nebraska, annual maximum peak flows can be very small or even zero. The lower-regime flows are essentially low outliers from the remaining peak-flow data. When these lower flows comprise a large proportion of the data, they cannot all be censored because Bulletin 17B analyses require that at least half of the data be used. If they are numerous enough and their range in flow is great enough, the computed peak-flow frequency curves are too steep and the indicated high-end peak flows can be unreasonable. Chadron Creek tributary at Chadron Creek State Park near Chadron (4455a) and Antelope Creek tributary near Gordon (4578) are two examples of this situation (fig. 5). For the Chadron Creek tributary station, 12 of the 26 peaks were zero and no more peaks could be cut off in the standard Bulletin 17B analyses or the calculations would abort. For this station the data were simply split into zero and non-zero flows, analyzed separately and then recombined with the conditional probability adjustment.

For the Antelope Creek tributary station (4578), less than half of the non-zero flows appear to be true indicators of flood flow and splitting the data into zero and non-zero flows does not produce a reasonable fit of the largest flows. The fairly obvious break used to split the non-zero flow data for this station is not always as apparent for other stations and is difficult to justify without more investigation. Another solution might be to use a different type of analysis that uses all of the peak flows above a selected base flow in the computations (partial-duration series) rather than just the annual maximum peak flows (annual maximum series). Some, if not all, of the lower peak flows from dry years potentially could be replaced in the analyses with larger peak flows from wetter years. Unfortunately, all of the stations 

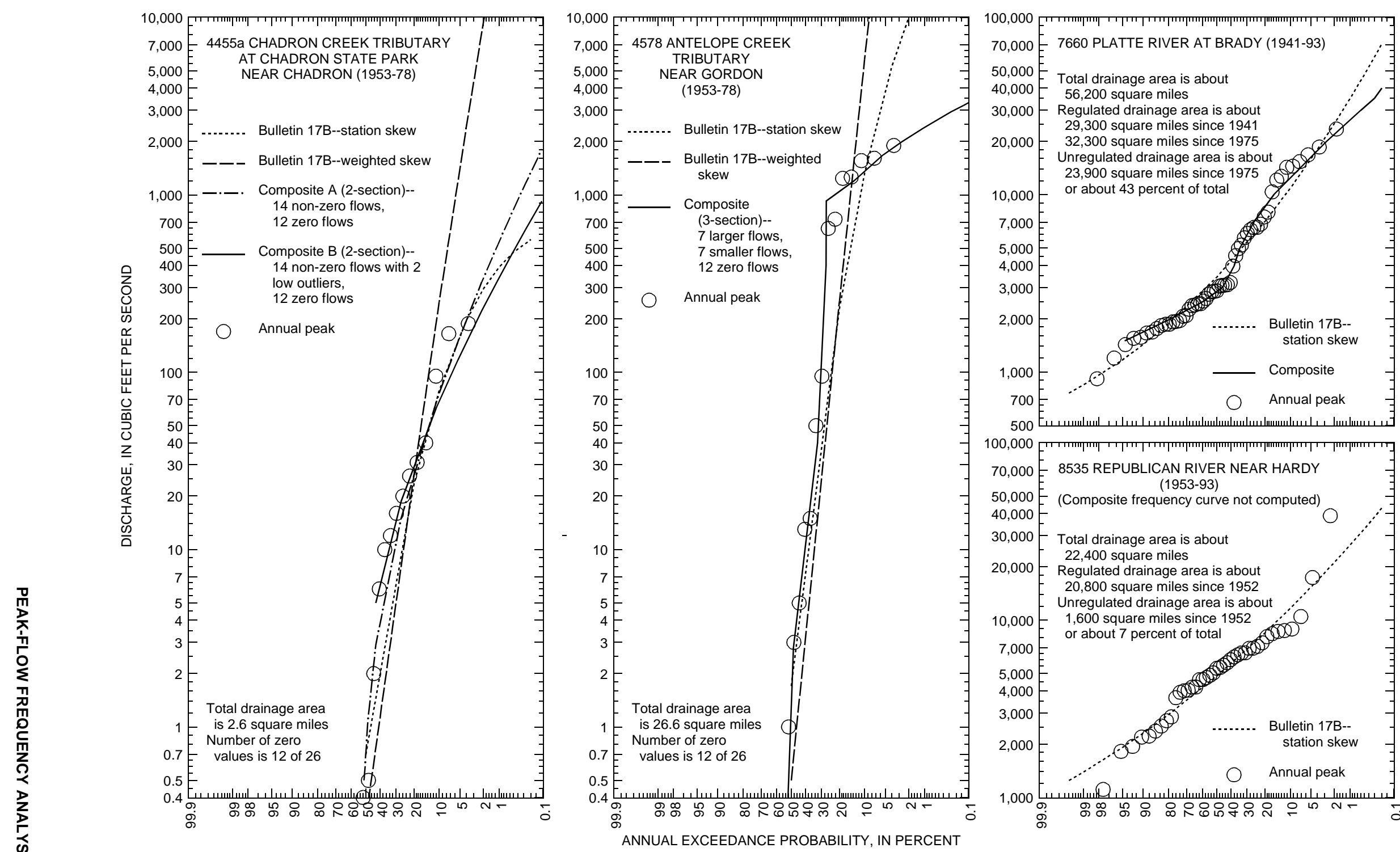

500

00,000

$70,000-8535$ REPUBLICAN RIVER NEAR HARDY

(1953-93)

(Composite frequency curve not computed)

30,000 - Total drainage area is about

22,400 square miles

20,000 F Regulated drainage area is about

20,800 square miles since 1952

$10,000=1,600$ square miles since 1952

$7,000=$ or about 7 percent of total

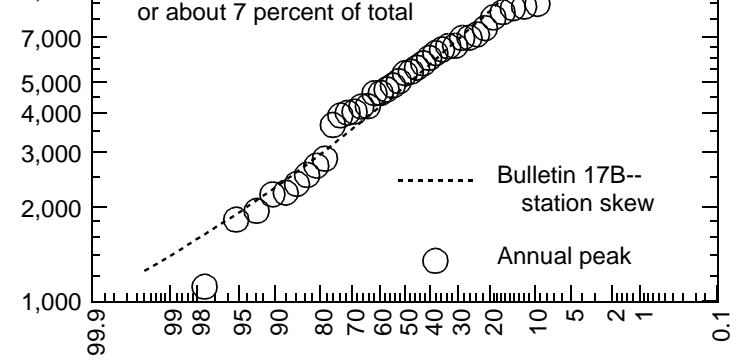

Figure 5. Four examples of Nebraska streamflow-gaging stations requiring composite frequency curves because of apparent mixed populations of data that are not caused by 
where this was observed were operated as peak-stage gages where only annual maximum peaks were reported. For both the Chadron Creek and Antelope Creek tributary stations, regional skews were used when analyzing the higher flows.

For regulated or partially regulated streams, the farther downstream from a control structure a station is located, the more likely it is that peaks will be produced from the unregulated drainage area between the structure and the station; even a small amount of drainage area can produce a large peak if a storm over the area is intense enough. The Republican River at Hardy (8535) is an example of a partially regulated station with an apparent mixed population (fig. 5). Based on a comparison with two other long-term stations between the Hardy station and the Harlan County Dam upstream, it is apparent that at least the two largest peaks at the Hardy station, which are distinctly different from the majority of the other peaks, were produced from the unregulated drainage area below the dam.

\section{PEAK-FLOW FREQUENCY RELATIONS}

Peak-flow frequency relations were developed for standard exceedance probabilities of 50, 20, 10, 4, $2,1,0.5$, and 0.2 percent, or frequencies of occurrence (recurrence intervals) of 2, 5, 10, 25, 50, 100, 200, and 500 years, respectively. For unregulated streams, eight sets of regression equations relating drainage-basin characteristics to annual peak flows for selected frequencies of occurrence were developed for seven regions of the state. Two sets of regional peak-flow frequency equations were developed for a high-permeability region that includes basins with $P 60$ greater than $4 \mathrm{in} / \mathrm{hr}$. Six sets of equations were developed for specific geographic areas, primarily on the basis of drainage-basin boundaries. One set of the high-permeability equations was developed using data from standard frequency analyses and the other was developed using data from composite frequency analyses. In general, the two sets of high-permeability equations were developed for basins with sandhills-type terrain. Statewide regression equations also were computed, but they are not presented because MSEs were larger than those for regional equations. Data from stations in Wyoming, South Dakota, Colorado, and Kansas were used along with data from stations in Nebraska in the development of unregulated peak-flow frequency relations (fig. 6).

Stations along streams with flows that are known to have been or possibly could have been affected to some degree by regulation (flood control, irrigation diversions, power generation, storage detention, or other factors) were excluded from regional analyses relating drainage-basin characteristics to peak-flow characteristics (fig. 7). Log-linear relations of peak-flow frequency and distance upstream from the mouth were developed for parts of nine streams.

\section{Unregulated Streams}

Using analyses for stations with at least 10 years of record, preliminary peak-flow frequency equations were developed and regions were defined using ordinary least squares (OLS) multiple-regression procedures. Final equations were developed using a generalized least squares (GLS) multipleregression procedure. OLS regression procedures were used to identify the most likely combinations of drainage-basin characteristics for the development of peak-flow frequency equations and to define regions.

OLS regression analyses were done using Statit statistical programs (Statware, Inc., 1990). Peak-flow data were transformed to base-10 logarithms $\left(\log _{10}\right)$. Several additional drainage-basin characteristics were computed using Statit from the existing characteristics before $\log _{10}$ and reciprocal transforms were computed. Correlation coefficients and plots of the data were used to screen out drainage-basin characteristics that were highly correlated with each other or were poorly distributed relative to the peak-flow data for statistical analyses. Multiple-regression programs ALLREG, GREGRES, and REGRES (Statware, Inc., 1990) were used to identify statistically significant combinations of explanatory variables (basin characteristics) for predicting peak flows for standard frequencies of occurrence. Initial selection of explanatory variables for OLS regression equations was based primarily on minimizing the Mallow's Cp statistic in ALLREG. Mallow's Cp was used to achieve a balance between minimizing bias, by including all relevant variables, and minimizing the variance of the estimator, by keeping the number of variables small (E.J. Gilroy, D.R. Helsel, and T.A. Cohen, USGS, written commun., 1991). 

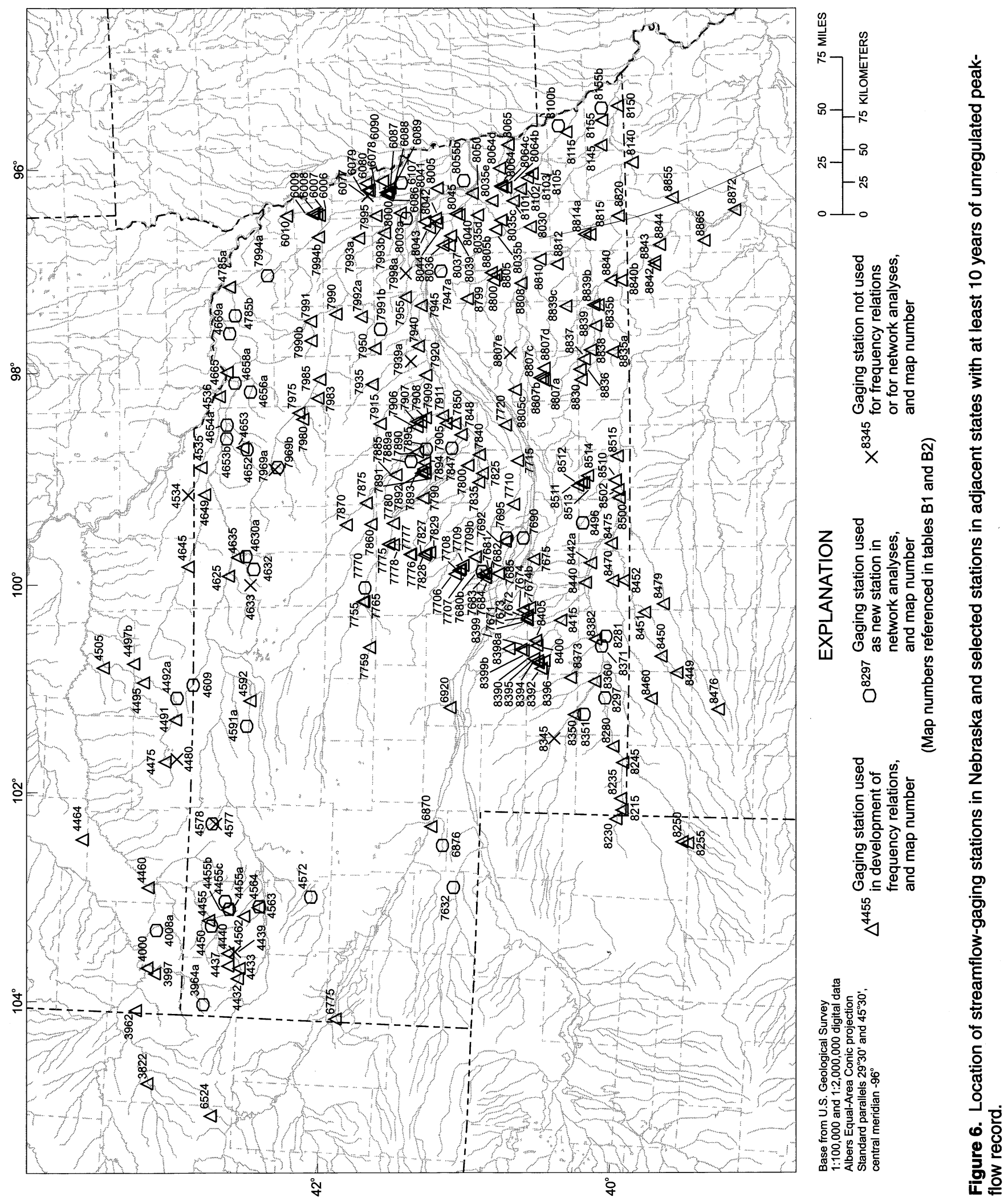


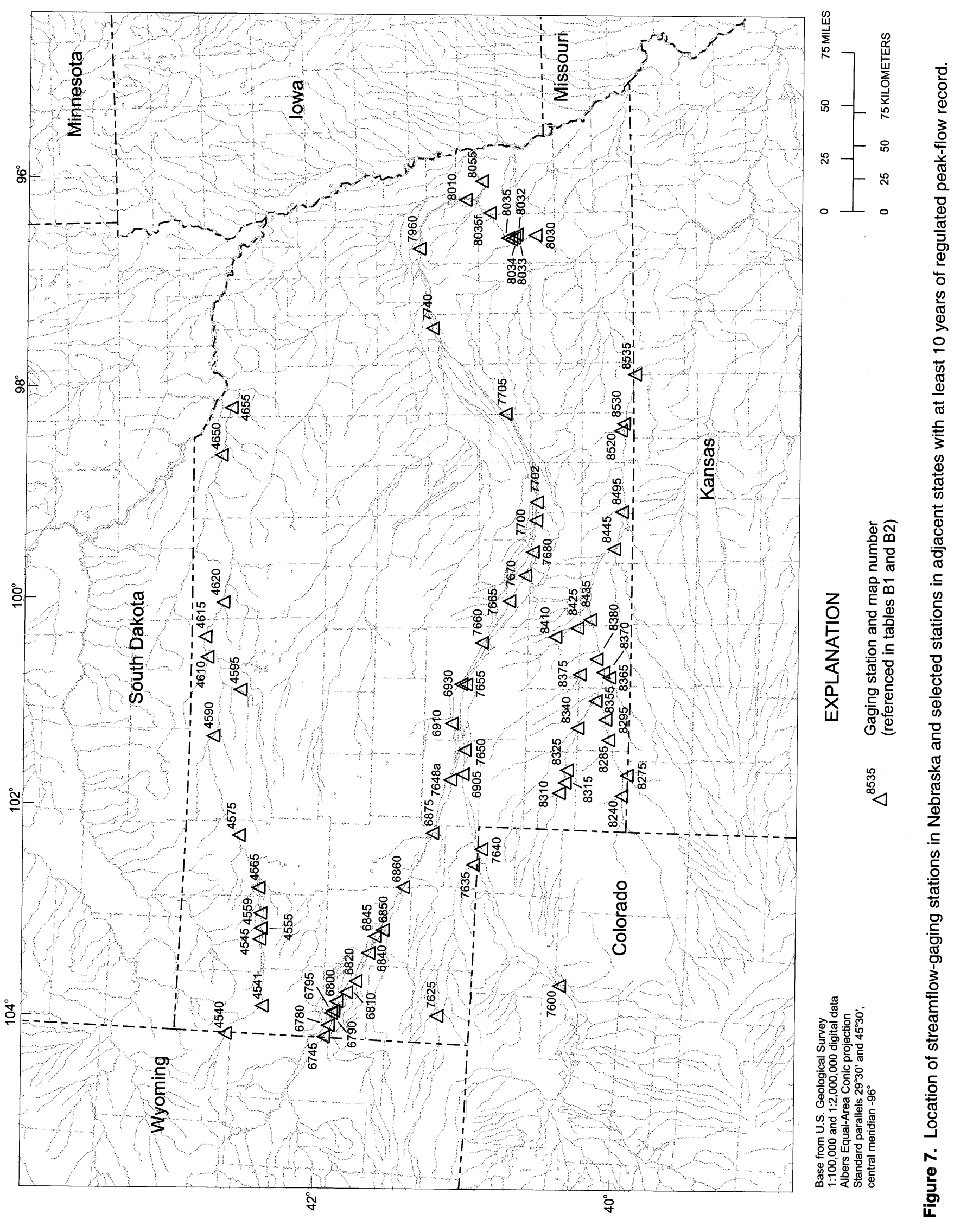


This also usually resulted in minimizing the MSE and in keeping the absolute value of the t-ratios greater than 2. The t-ratio was computed for each explanatory variable as the fitted coefficient divided by its standard error; it was used to test whether or not the coefficient (slope) of each explanatory variable was significantly different than zero.

\section{Regional Equations}

Residual values and plots from preliminary OLS regression analyses were used to delineate the six hydrologic regions (fig. 8) based on geography and outlier stations before final regression equations were developed using the GLS program in GLSNET (Gary Tasker, USGS, written commun., 1995). The GLS program adjusts for differences in record lengths, differences in peak-flow variances, and cross-correlations of concurrent peak-flows among stations used in the regression analysis (Tasker and Stedinger, 1989). Only $\log _{10}$ transforms of peak-flow and drainage-basin characteristic data were used for GLS regression analyses. This allowed for the simple transformation of the final equations to exponential form. Selection of drainage-basin characteristics as explanatory variables for GLS regression equations was based primarily on minimizing the GLS version of the prediction error sum of squares, or PRESS statistic, (Gilroy and Tasker, 1989; and E.J. Gilroy, D.R. Helsel, and T.A. Cohen, USGS, written commun., 1991) and, to a lesser extent, on minimizing the standard error of prediction (SEP).

The PRESS statistic is the sum of the squared prediction residuals. The prediction residuals are the differences between each observed value of the dependent variable and its predicted value that is determined from a regression equation computed with all data except that of the observed value for which the residual is being determined. The SEP was preferable to the standard error of estimate (SEE) for equation comparisons because the SEE is based only on the model error (error in the equation that will change only if the equation itself is changed, not by collecting more data) while the SEP also includes the sampling error (error in estimating the true equation parameters from limited data) (Gary Tasker, U.S. Geological Survey, written commun., 1995). The t-ratios for each of the explanatory variables also were examined; those with an absolute value of less than 2 were not used, in most cases. Also, explanatory variables that were not considered hydrologically valid were eliminated from the regression analyses on a case-bycase basis.

Short-record stations with less than 15 years of peak-flow record were not used, except for two regions in eastern and southeastern Nebraska. In general, use of short-record stations added considerable variability to peak-flow frequency relations; commonly, these stations had individual peak-flow frequency relations that did not fit the data well. Stations with an excessive number of low outliers that precluded development of reasonable peakflow frequency curves, most typically in northern and western Nebraska, also were not used (see previous discussion "Composite Analyses"). In addition, stations with total drainage areas (TDA) of less than $1 \mathrm{mi}^{2}$ generally were not used. For most regions where a slope characteristic was identified as significant, stations with drainage areas of less than $5 \mathrm{mi}^{2}$ were not used. The 1:250,000-scale DEM data used to quantify basin characteristics resulted in some characteristics that were regarded as too low and unreliable for use in the regression analyses - this was particularly evident for basins with small drainage areas and low relief.

For both OLS and GLS regression analyses, allowances were made in the basic selection process to try to keep drainage-basin characteristics consistent for the various peak-flow frequency equations within a region. This was not always possible, however, and some equations for the same region have different sets of characteristics as explanatory variables. Judgement must to be used in the application of these equations in these situations.

For each region, equations were developed for the 2-, 5-, 10-, 25-, 50-, 100-, 200-, and 500-year frequencies of occurrence (recurrence intervals), designated as $Q_{2}, Q_{5}, Q_{10}, Q_{25}, Q_{50}, Q_{100}, Q_{200}$, and $Q_{500}$ respectively. A table of equations for each region with summary statistics follows a discussion of each of the regions. There is overlap between several of the regions where more than one equation can be used to estimate peak flows. 


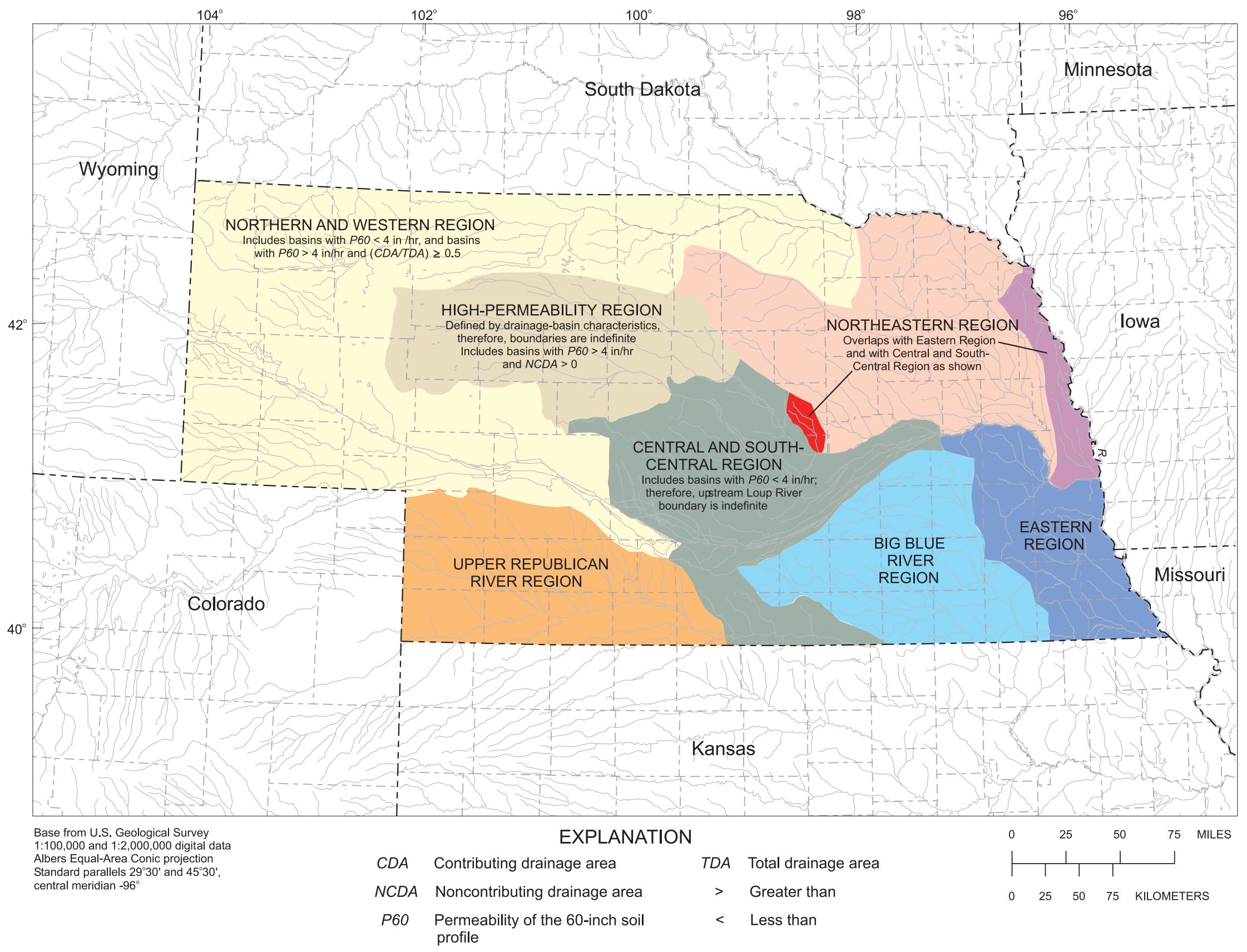

Figure 8. Hydrologic regions in Nebraska for unregulated peak-flow frequency equations. 
Tables of equations include: the average sampling error (ASE), average model error (AME), SEP, and SEE — all based on the $\log _{10}$ transforms of the data; SEE in percent of the untransformed data; and the average equivalent years of record (AEYR) for each equation. SEP was computed as the square root of the sum of ASE and AME. SEE was computed as the square root of AME (Gary Tasker, U.S. Geological Survey, written commun., 1995). For comparisons to equations developed by Beckman (1976), for which SEPs were not reported, SEEs in percent were computed from the SEEs in $\log _{10}$ units using tabled values from Tasker (1978, p. 87). The AEYR is an estimate of the number of years of at-site streamflow data that would be required to predict the streamflow characteristic with accuracy equivalent to that of the regression equation (Hardison, 1971, p. C232). The explanatory variables are listed in the equations in the order of decreasing t-ratios from the GLS output. This was done to illustrate the changing significance, if any, among the variables from one frequency of occurrence (recurrence interval) to another.

For unregulated stations, estimated peak flows were computed (table B2) from the applicable regional equations using basin-characteristic data (table B1). Code(s) designating the applicable set of regional equation(s) are also listed for each station.

\section{High Permeability Region}

This region generally includes drainage basins with sandhills terrain (figs. 1 and 8); it includes a large area of Nebraska, not all of it contiguous, and smaller areas in Colorado, South Dakota, and Wyoming. The region is nearly coincident with Beckman's Region 2 (1976, p. 10-11), which was defined geographically; in this report the region is defined by basin characteristics. Only basins with $P 60$ greater than $4 \mathrm{in} / \mathrm{hr}$ and with some noncontributing drainage area $(N C D A)$ were used to develop the equations. These criteria eliminated the lower Niobrara River Basin stations downstream of Long Pine Creek (fig. 1). Although these basins have values of $P 60$ greater than $4 \mathrm{in} / \mathrm{hr}$, they have little or no NCDA and the terrain is distinctly different from that of the nearby sandhills areas, as determined from visual inspection of topographic maps. Peak-flow frequency data from these basins also did not fit well with that from the sandhillstype basins. Consequently, the lower Niobrara
River Basin is included within one of the six geographically based regions.

Equations for the High-Permeability Region and standard-frequency analyses (HPS) (table 2) are based on data from 49 stations with at least 15 years of record and TDAs of 94.8 to $15,200 \mathrm{mi}^{2}$. The explanatory variables for the HPS equations were not entirely consistent for all frequencies. Contributing drainage area $(C D A)$ and mean annual precipitation $(M A P)$ were the two most significant variables in all equations. Basin slope $(B S)$ was significant at the smaller frequencies, and available water capacity $(A W C)$ and main-channel slope $(M C S)$ were significant at the middle and larger frequencies. Stations with TDAs less than $5 \mathrm{mi}^{2}$ were not considered because $B S$ and $M C S$ were in the equations (see previous discussion of Regional Equations).

Equations for the High-Permeability Region and composite-frequency analyses $(H P C)$ (table 2) were based on data from 23 stations with at least 20 years of record and TDAs of 172 to $4,490 \mathrm{mi}^{2}$. The number of stations used to develop the regression equations was limited because of the amount of time required to compute the compositefrequency curves. Also, not every high-permeability station had enough peaks in the higher-flow regime to which a separate peak-flow frequency curve could be fitted. The explanatory variables for the composite-analysis equations are very similar to those for the standard-analysis equations except for the addition of drainage frequency $(D F)$, which is significant for all frequencies.

SEEs for both sets of high-permeability equations are lower than are those corresponding to Beckman's Region 2 (1976, p. 60) equations. The SEEs for the standard equations generally are lower than are those for the composite equations; this could be because of the limited number of stations used to develop the composite equations. However, the peak-flow frequency curves that are the basis for the composite equations are considered to fit the peak-flow frequency data better at the high ends than do the standard peak-flow frequency curves. Judgment is required in determining which equations should be used in a particular instance. 
Table 2. Peak-flow equations for the High-Permeability Region

[AEYR, average equivalent years of record; AME, average model error; ASE, average sampling error; $A W C$, available water capacity of 60-inch soil profile, in inches per inch; $B S$, basin slope, in feet per mile; $C D A$, contributing drainage area, in square miles; $D F$, drainage frequency, in first-order streams per square mile; $M A P$, mean annual precipitation, in inches; $M C S$, main-channel slope, in feet per mile; $Q$, peak discharge, in cubic feet per second, for a given recurrence interval, in years; SEE, standard error of estimate; SEP, standard error of prediction]

\begin{tabular}{|c|c|c|c|c|c|c|}
\hline \multirow[b]{2}{*}{ Estimation equation } & ASE & AME & SEP & SEE & \multirow{2}{*}{$\begin{array}{l}\text { SEE } \\
\text { (per- } \\
\text { cent) }\end{array}$} & \multirow[b]{2}{*}{$\begin{array}{c}\text { AEYR } \\
\text { (years) }\end{array}$} \\
\hline & \multicolumn{4}{|c|}{$\begin{array}{l}\text { (based on variables in } \\
\log _{10} \text { units) }\end{array}$} & & \\
\hline \multicolumn{7}{|l|}{ Standard analysis } \\
\hline \multicolumn{7}{|c|}{ (49 stations with 25 or more years of record) } \\
\hline$Q_{2}=0.0662 C D A^{0.750}(M A P-15)^{0.548} B S^{0.933}$ & 0.003 & 0.030 & 0.183 & 0.174 & 41.8 & 3.6 \\
\hline$Q_{5}=0.408 C D A^{0.777}(M A P-15)^{0.525} B S^{0.653}$ & .004 & .030 & .182 & .172 & 41.2 & 7.0 \\
\hline$Q_{10}=8.76 C D A^{0.736}(M A P-15)^{0.527} B S^{0.539} A W C^{0.835}$ & .005 & .031 & .189 & .176 & 42.2 & 9.7 \\
\hline$Q_{25}=14.8 C D A^{0.773}(M A P-15)^{0.695} A W C^{1.17} M C S^{0.546} B S^{0.318}$ & .007 & .033 & .200 & .181 & 43.5 & 13.2 \\
\hline$Q_{50}=73.2 C D A^{0.779}(M A P-15)^{0.756} A W C^{1.35} M C S^{0.766}$ & .007 & .036 & .208 & .189 & 45.8 & 15.9 \\
\hline$Q_{100}=119 C D A^{0.777}(M A P-15)^{0.787} A W C^{1.56} M C S^{0.860}$ & .008 & .038 & .214 & .195 & 47.2 & 18.7 \\
\hline$Q_{200}=184 C D A^{0.774}(M A P-15)^{0.816} A W C^{1.74} M C S^{0.942}$ & .009 & .041 & .224 & .203 & 49.3 & 20.8 \\
\hline$Q_{500}=313 C D A^{0.769}(M A P-15)^{0.850} A W C^{1.94} M C S^{1.04}$ & .011 & .047 & .240 & .217 & 53.1 & 22.7 \\
\hline \multicolumn{7}{|l|}{ Composite analysis } \\
\hline \multicolumn{7}{|c|}{ ( 23 stations with 20 or more years of record) } \\
\hline$Q_{2}=0.127 C D A^{0.684} B S^{0.968}(M A P-15)^{0.715} D F^{0.456}$ & .006 & .022 & .167 & .149 & 35.4 & 3.3 \\
\hline$Q_{5}=1.09 C D A^{0.774}(M A P-15)^{0.590} B S^{0.576} D F^{0.454}$ & .008 & .031 & .196 & .175 & 42.0 & 5.2 \\
\hline$Q_{10}=21.8 C D A^{0.744}(M A P-15)^{0.626} B S^{0.602} D F^{0.399} A W C^{1.17}$ & .011 & .033 & .211 & .182 & 43.9 & 7.1 \\
\hline$Q_{25}=159 C D A^{0.805}(M A P-15)^{0.718} D F^{0.637} A W C^{1.40} M C S^{0.773}$ & .014 & .038 & .229 & .195 & 47.2 & 9.2 \\
\hline$Q_{50}=368 C D A^{0.817}(M A P-15)^{0.730} D F^{0.637} A W C^{1.76} M C S^{0.864}$ & .016 & .040 & .238 & .201 & 48.8 & 11.3 \\
\hline$Q_{100}=776 C D A^{0.828}(M A P-15)^{0.741} A W C^{2.07} D F^{0.641} M C S^{0.941}$ & .019 & .044 & .251 & .210 & 51.4 & 13.0 \\
\hline$Q_{200}=1,520 C D A^{0.838} A W C^{2.35}(M A P-15)^{0.752} D F^{0.645} M C S^{1.01}$ & .022 & .050 & .267 & .223 & 55.0 & 14.1 \\
\hline$Q_{500}=3,390 C D A^{0.851} A W C^{2.67}(M A P-15)^{0.767} D F^{0.654} M C S^{1.09}$ & .026 & .060 & .293 & .244 & 61.0 & 15.0 \\
\hline
\end{tabular}

APPLICABLE RANGES OF VARIABLES:

Standard-analysis equations-CDA 8.6-6,230; MAP 15.12-26.09; AWC 0.07-0.17; MCS 4.41-28.22; BS 41.0-286

Composite-analysis equations-CDA 8.6-1,310; BS 55.7-249; MAP 16.39-26.09; DF 0.05-0.60;

AWC $0.08-0.15 ; \quad M C S$ 5.6-19.4

NOTE: $B S, M C S$, and $D F$ are data-scale dependent. 


\section{Northern and Western Region}

This region was developed from stations in eastern Wyoming, southern South Dakota, and northern and western Nebraska and includes the Cheyenne, White, and Niobrara River Basins except as noted (figs. 1 and 8). The region is roughly coincident with Beckman's Region 1 (1976, p. 10-11), but excludes (1) the Niobrara River mainstem, (2) the Platte River Basin downstream of where the sandhills near the Platte River end along the left bank of the Platte and downstream of Plum Creek on the right bank, and (3 the Republican River Basin. There is some overlap with the High-Permeability Region, because stations with $P 60$ greater than $4 \mathrm{in} / \mathrm{hr}$ were used if the ratio of $C D A$ to $T D A$ was at least 50 percent.

Equations for the Northern and Western Region (table 3 ) are based on data from 34 stations with at least 15 years of record and TDAs of 0.6 to 2,160 $\mathrm{mi}^{2}$. CDA and MAP are significant explanatory variables at all frequencies. Relative relief $(R R)$ and average permeability of the least permeable layer $(P L P)$ are significant for the $Q_{2}$ through $Q_{50}$ equations, and $B S$ is a significant explanatory variable for the $Q_{100}$ through $Q_{500}$ equations. SEEs for all equations, except for $Q_{2}$, are lower than Beckman's Region 1 equations (1976, p. 60), especially at the larger frequencies.

Table 3. Peak-flow equations for the Northern and Western Region

[AEYR, average equivalent years of record; AME, average model error; ASE, average sampling error; $B S$, basin slope, in feet per mile; $C D A$, contributing drainage area, in square miles; $M A P$, mean annual precipitation, in inches; $P L P$, permeability of least permeable layer, in inches per hour; $Q$, peak discharge, in cubic feet per second, for a given recurrence interval, in years; $R R$, relative relief, in feet per mile; SEE, standard error of estimate; SEP, standard error of prediction]

\begin{tabular}{|c|c|c|c|c|c|c|}
\hline \multirow[b]{2}{*}{ Estimation equation } & ASE & AME & SEP & SEE & \multirow{2}{*}{$\begin{array}{l}\text { SEE } \\
\text { (per- } \\
\text { cent) }\end{array}$} & \multirow[b]{2}{*}{$\begin{array}{r}\text { AEYR } \\
\text { (years) }\end{array}$} \\
\hline & \multicolumn{4}{|c|}{$\begin{array}{c}\text { (based on variables in } \\
\log _{10} \text { units) }\end{array}$} & & \\
\hline \multicolumn{7}{|c|}{ (34 stations with 15 or more years of record) } \\
\hline$Q_{2}=0.176 C D A^{0.762} R R^{0.878}(M A P-12)^{0.929} P L P^{-0.357}$ & 0.032 & 0.180 & 0.460 & 0.424 & 126 & 1.7 \\
\hline$Q_{5}=0.686 C D A^{0.642} R R^{0.932}(M A P-12)^{1.05} P L P^{-0.360}$ & .014 & .061 & .275 & .247 & 61.8 & 6.0 \\
\hline$Q_{10}=1.69 C D A^{0.577}(M A P-12)^{1.08} R R^{0.892} P L P^{-0.337}$ & .014 & .049 & .251 & .222 & 54.5 & 9.5 \\
\hline$Q_{25}=5.06 C D A^{0.508}(M A P-12)^{1.07} R R^{0.802} P L P^{-0.302}$ & .016 & .050 & .257 & .224 & 55.2 & 12.4 \\
\hline$Q_{50}=10.7 C D A^{0.464}(M A P-12)^{1.06} R R^{0.731} P L P^{-0.272}$ & .018 & .056 & .271 & .236 & 58.5 & 13.5 \\
\hline$Q_{100}=35.2 C D A^{0.213} B S^{0.589}(M A P-12)^{0.643}$ & .018 & .064 & .288 & .254 & 63.8 & 14.0 \\
\hline$Q_{200}=37.4 C D A^{0.192} B S^{0.629}(M A P-12)^{0.711}$ & .020 & .067 & .295 & .259 & 65.3 & 15.3 \\
\hline$Q_{500}=41.6 C D A^{0.168} B S^{0.669}(M A P-12)^{0.786}$ & .023 & .075 & .313 & .274 & 70.0 & 16.1 \\
\hline
\end{tabular}

APPLICABLE RANGES OF VARIABLES: $\quad C D A \quad 0.61-2,160 ; \quad R R \quad 4.2-48.3 ; \quad M A P$ 14.19-24.69; $\quad P L P \quad 0.10-5.00 ; B S$ 52.5-462

NOTE: $B S$ and $R R$ are data-scale dependent. 


\section{Northeastern Region}

This region covers most of the northeastern part of Nebraska. It includes (1) the right bank Missouri River tributary basins downstream of the Niobrara River and upstream of the Platte River, (2) the left bank Platte River tributary basins downstream of the Loup River, and (3) the left bank Loup River tributary basins downstream of the North Loup River (figs. 1 and 8). It includes all of Beckman's Region 3 (1976, p. 1011) north of the Platte River plus some other areas farther west. Unlike Beckman's Region 3, but similar to the Northern and Western Region, there is some overlap of the Northeastern Region with the High-Permeability Region (P60 greater than $4 \mathrm{in} / \mathrm{hr}$ ), most notably the entire basins of the
Elkhorn and Cedar Rivers and Beaver Creek. The left bank Loup River tributary basins also overlap with the low-permeability Central and SouthCentral Region discussed next.

Equations for the Northeastern Region (table 4) are based on data from 40 stations with at least 15 years of record and TDAs of 1.5 to $6,950 \mathrm{mi}^{2} . T D A$, shape factor $(S F)$, and $D F$ are significant explanatory variables for all of the Northeastern Region equations. PLP is the second most significant variable for the $Q_{2}$ and $Q_{5}$ equations, but it becomes less significant at larger frequencies and is not significant for the $Q_{200}$ and $Q_{500}$ equations. SEEs for all equations are lower than Beckman's Region 3 equations (1976, p. 60).

Table 4. Peak-flow equations for the Northeastern Region

[AEYR, average equivalent years of record; AME, average model error; ASE, average sampling error; $D F$, drainage frequency, in first-order streams per square mile; $P L P$, permeabilitiy of the least permeable layer, in inches per hour; $Q$, peak discharge, in cubic feet per second, for a given recurrence interval, in years; SEE, standard error of estimate; SEP, standard error of prediction; SF, shape factor, dimensionless; TDA, total drainage area, in square miles]

\begin{tabular}{|c|c|c|c|c|c|c|}
\hline \multirow[b]{2}{*}{ Estimation equation } & ASE & AME & SEP & SEE & \multirow{2}{*}{$\begin{array}{l}\text { SEE } \\
\text { (per- } \\
\text { cent) }\end{array}$} & \multirow[b]{2}{*}{$\begin{array}{c}\text { AEYR } \\
\text { (years) }\end{array}$} \\
\hline & \multicolumn{4}{|c|}{$\begin{array}{l}\text { (based on variables } \\
\text { in } \log _{10} \text { units) }\end{array}$} & & \\
\hline \multicolumn{7}{|c|}{ (40 stations with 15 or more years of record) } \\
\hline$Q_{2}=132 T D A^{0.676} P L P^{-0.592} S F^{-0.335} D F^{0.295}$ & 0.007 & 0.037 & 0.209 & 0.191 & 46.2 & 4.4 \\
\hline$Q_{5}=395 T D A^{0.652} P L P^{-0.514} S F^{-0.421} D F^{0.323}$ & .006 & .023 & .170 & .153 & 36.3 & 8.6 \\
\hline$Q_{10}=715 T D A^{0.633} S F^{-0.469} P L P^{-0.443} D F^{0.338}$ & .006 & .022 & .167 & .147 & 34.9 & 11.9 \\
\hline$Q_{25}=1,360 T D A^{0.612} S F^{-0.518} D F^{0.356} P L P^{-0.352}$ & .007 & .023 & .173 & .151 & 35.8 & 15.2 \\
\hline$Q_{50}=2,070 T D A^{0.597} S F^{-0.548} D F^{0.370} P L P^{-0.286}$ & .008 & .025 & .182 & .157 & 37.5 & 16.9 \\
\hline$Q_{100}=3,000 T D A^{0.583} S F^{-0.573} D F^{0.384} P L P^{-0.223}$ & .010 & .028 & .192 & .166 & 39.6 & 17.9 \\
\hline$Q_{200}=5,240 T D A^{0.562} S F^{-0.667} D F^{0.452}$ & .009 & .031 & .201 & .176 & 42.3 & 19.0 \\
\hline$Q_{500}=7,030 T D A^{0.551} S F^{-0.655} D F^{0.440}$ & .011 & .034 & .213 & .185 & 44.7 & 20.1 \\
\hline
\end{tabular}

APPLICABLE RANGES OF VARIABLES: TDA $1.50-6,950 ; \quad P L P \quad 0.38-5.56 ; \quad S F \quad 0.49-56.4 ; \quad D F \quad 0.01-1.33$

NOTE: $D F$ is data-scale dependent. 


\section{Central and South-Central Region}

This region consists of low-permeability (P6O less than $4 \mathrm{in} / \mathrm{hr}$ ) basins, generally south and east of the central sandhills, that are tributaries within the middle Platte, Loup, and middle Republican River Basins (figs. 1 and 8). It includes (1) left bank Platte River tributary basins downstream of where the sandhills end along the left bank of the Platte River to just downstream of the Loup River but excluding the left-bank Loup River tributary basins downstream of Spring Creek (shortly below the confluences of the Middle and North Loup Rivers)—Beckman's Region 4 (1976, p. 10-11), and (2) Republican River tributary basins in Nebraska downstream of Harlan County Dam-part of Beckman's Region 1 (1976, p. 1011). The Central and South-Central Region is presumed to include right bank Platte River tributary basins, for which there are no stations, downstream of Plum Creek, to the Loup River. Spring Creek, a left-bank Loup River tributary, overlaps with the Northeastern Region.

Equations for the Central and South-Central Region (table 5) are based on data from 37 stations with at least 15 years of record and with TDAs of 1.5 to $711 \mathrm{mi}^{2}$. Explanatory variables are the same for all equations, and include $T D A, R R$, 2-year, 24-hour precipitation (TTP), and $S F$. For the $Q_{2}$ and $Q_{5}$ equations, TTP is the second most significant variable, but for equations $Q_{10}$ and larger, $R R$ is more significant. SEEs are lower than Beckman's Region 1 equations (1976, p. 60), and lower than Beckman's Region 4 equations (1976, p. 60) for equations $Q_{25}$ and larger.

Table 5. Peak-flow equations for the Central and South-Central Region

[AEYR, average equivalent years of record; AME, average model error; ASE, average sampling error; $Q$, peak discharge, in cubic feet per second, for a given recurrence interval, in years; $R R$, relative relief, in feet per mile; SEE, standard error of estimate; SEP, standard error of prediction; $S F$, shape factor, dimensionless; TDA, total drainage area, in square miles; TTP, 2-year, 24-hour precipitation, in inches]

\begin{tabular}{|c|c|c|c|c|c|c|}
\hline \multirow[b]{2}{*}{ Estimation equation } & ASE & AME & SEP & SEE & \multirow{2}{*}{$\begin{array}{l}\text { SEE } \\
\text { (per- } \\
\text { cent) }\end{array}$} & \multirow[b]{2}{*}{$\begin{array}{c}\text { AEYR } \\
\text { (years) }\end{array}$} \\
\hline & \multicolumn{4}{|c|}{$\begin{array}{l}\text { (based on variables } \\
\text { in } \log _{10} \text { units) }\end{array}$} & & \\
\hline \multicolumn{7}{|c|}{ (37 stations with 15 or more years of record) } \\
\hline$Q_{2}=54.8 T D A^{0.994}(T T P-2)^{4.24} S F^{-0.738} R R^{1.00}$ & 0.016 & 0.072 & 0.297 & 0.269 & 68.3 & 4.1 \\
\hline$Q_{5}=73.4 T D A^{0.942}(T T P-2)^{3.98} R R^{1.32} S F^{-0.647}$ & .011 & .038 & .222 & .196 & 47.4 & 8.2 \\
\hline$Q_{10}=80.8 T D A^{0.931} R R^{1.51}(T T P-2)^{3.92}(S F)^{-0.614}$ & .012 & .035 & .216 & .187 & 45.1 & 11.0 \\
\hline$Q_{25}=89.4 T D A^{0.923} R R^{1.71}(T T P-2)^{3.88} S F^{-0.587}$ & .014 & .039 & .230 & .198 & 47.9 & 13.0 \\
\hline$Q_{50}=96.4 T D A^{0.918} R R^{1.83}(T T P-2)^{3.84} S F^{-0.572}$ & .016 & .045 & .247 & .212 & 51.8 & 13.5 \\
\hline$Q_{100}=104 T D A^{0.914} R R^{1.93}(T T P-2)^{3.83} S F^{-0.560}$ & .019 & .052 & .263 & .228 & 56.4 & 13.6 \\
\hline$Q_{200}=111 T D A^{0.910} R R^{2.02}(T T P-2)^{3.81} S F^{-0.549}$ & .021 & .060 & .285 & .245 & 61.3 & 13.5 \\
\hline$Q_{500}=121 T D A^{0.906} R R^{2.12}(T T P-2)^{3.80} S F^{-0.538}$ & .025 & .072 & .310 & .268 & 68.0 & 13.2 \\
\hline
\end{tabular}

APPLICABLE RANGES OF VARIABLES: TDA $1.50-711 ; \quad T T P \quad 2.35-2.55 ; \quad S F \quad 0.89-13.0 ; \quad R R \quad 2.72-21.4$

NOTE: $R R$ is data-scale dependent. 


\section{Eastern Region}

This region consists of Missouri River tributary basins from and including Omaha Creek (several miles below the mouth of the Big Sioux River) to the Nebraska-Kansas state line, but only includes Platte River tributary basins downstream of Hydrologic Unit 10200103 (U.S. Geological Survey, 1976)(which extends several miles below the mouth of the Loup River) along the right bank and downstream of the Elkhorn River along the left bank (figs. 1 and 8). It is a sub-area of Beckman's Region 3 (1976, p. 10-11). The Eastern Region north of the Platte River overlaps with the Northeastern Region.
Equations for the Eastern Region (table 6) are based on data from 42 stations with at least 10 years of record and TDAs of 1.6 to $1,640 \mathrm{mi}^{2}$. The explanatory variables of $C D A, B S$ and, $P L P$ are consistent for all equations. SEEs are lower than Beckman's Region 3 equations (1976, p. 60), especially at the larger frequencies. Five stations with TDAs less than $5 \mathrm{mi}^{2}$ were used to develop the equations even though $B S$ was a significant explanatory variable; all values of $B S$ for the five stations were relatively large (greater than $100 \mathrm{ft} / \mathrm{mi}$ ) and appeared very reasonable compared to other stations in the region with larger TDAs.

Table 6. Peak-flow equations for the Eastern Region

[AEYR, average equivalent years of record; AME, average model error; ASE, average sampling error; $B S$, basin slope, in feet per mile; $C D A$, contributing drainage area, in square miles; $P L P$, permeability of the least permeable layer, in inches per hour; $Q$, peak discharge, in cubic feet per second, for a given recurrence interval, in years; SEE, standard error of estimate; SEP, standard error of prediction]

\begin{tabular}{|c|c|c|c|c|c|c|}
\hline \multirow[b]{2}{*}{ Estimation equation } & ASE & AME & SEP & SEE & \multirow{2}{*}{$\begin{array}{l}\text { SEE } \\
\text { (per- } \\
\text { cent) }\end{array}$} & \multirow[b]{2}{*}{$\begin{array}{c}\text { AEYR } \\
\text { (years) }\end{array}$} \\
\hline & \multicolumn{4}{|c|}{$\begin{array}{l}\text { (based on variables } \\
\text { in } \log _{10} \text { units) }\end{array}$} & & \\
\hline \multicolumn{7}{|c|}{ (42 stations with 10 or more years of record) } \\
\hline$Q_{2}=5.70 C D A^{0.558} B S^{0.655} P L P^{-0.470}$ & 0.006 & 0.036 & 0.206 & 0.191 & 46.1 & 4.4 \\
\hline$Q_{5}=21.1 C D A^{0.533} B S^{0.551} P L P^{-0.528}$ & .004 & .016 & .141 & .126 & 29.7 & 10.9 \\
\hline$Q_{10}=42.1 C D A^{0.519} B S^{0.495} P L P^{-0.537}$ & .004 & .012 & .125 & .107 & 25.1 & 18.0 \\
\hline$Q_{25}=90.2 C D A^{0.504} B S^{0.433} P L P^{-0.520}$ & .005 & .011 & .124 & .104 & 24.3 & 24.5 \\
\hline$Q_{50}=151 C D A^{0.494} B S^{0.390} P L P^{-0.498}$ & .005 & .012 & .131 & .109 & 25.4 & 26.6 \\
\hline$Q_{100}=242 C D A^{0.485} B S^{0.349} P L P^{-0.474}$ & .006 & .013 & .140 & .116 & 27.2 & 27.3 \\
\hline$Q_{200}=377 C D A^{0.476} B S^{0.310} P L P^{-0.450}$ & .007 & .015 & .150 & .124 & 29.3 & 27.2 \\
\hline$Q_{500}=650 C D A^{0.465} B S^{0.260} P L P^{-0.417}$ & .008 & .019 & .163 & .136 & 32.2 & 26.6 \\
\hline
\end{tabular}

APPLICABLE RANGES OF VARIABLES: $\quad C D A \quad 1.55-1,640 ; \quad B S \quad 12.8-315 ; \quad P L P \quad 0.13-0.60$

NOTE: $B S$ is data-scale dependent. 


\section{Upper Republican River Region}

This region was developed from stations in the Republican River Basin upstream of Harlan County Dam, and includes parts of southwestern Nebraska, northeastern Colorado, and northwestern Kansas (figs. 1 and 8). The South Fork of the Republican River (below Bonny Dam in Colorado) and the mainstem of the Republican River downstream of the South Fork are not included in this region because of regulation. Because the upper Republican River Region includes basins with $P 60$ greater than $4 \mathrm{in} / \mathrm{hr}$, it overlaps with the High-Permeability Region and contains parts of Beckman's Regions 1 and 2 (1976, p.10-11).
Equations for the Upper Republican River Region (table 7) are based on data from 33 stations with at least 15 years of record and TDAs of 6.8 to $7,740 \mathrm{mi}^{2}$. The explanatory variables $C D A, M C S$, and compactness ratio $(C R)$ are included in all of the equations, with $C R$ and $M C S$ varying in significance after $C D A$. SEEs are lower than Beckman's Region 1 and 2 equations (1976, p. 60), especially for Region 1. Stations with TDAs less than $5 \mathrm{mi}^{2}$ were not used to develop the equations because $M C S$ is a significant explanatory variable (see previous discussion of "Regional Equations").

Table 7. Peak-flow equations for the Upper Republican River Region

[AEYR, average equivalent years of record; AME, average model error; ASE, average sampling error; $C D A$, contributing drainage area, in square miles; $C R$, compactness ratio, dimensionless; $M C S$, main-channel slope, in feet per mile; $Q$, peak discharge, in cubic feet per second, for a given recurrence interval, in years; SEE, standard error of estimate; SEP, standard error of prediction]

\begin{tabular}{|c|c|c|c|c|c|c|}
\hline \multirow[b]{2}{*}{ Estimation equation } & ASE & AME & SEP & SEE & \multirow{2}{*}{$\begin{array}{l}\text { SEE } \\
\text { (per- } \\
\text { cent) }\end{array}$} & \multirow[b]{2}{*}{$\begin{array}{c}\text { AEYR } \\
\text { (years) }\end{array}$} \\
\hline & \multicolumn{4}{|c|}{$\begin{array}{l}\text { (based on variables } \\
\text { in } \log _{10} \text { units) }\end{array}$} & & \\
\hline \multicolumn{7}{|c|}{ (33 stations with 15 or more years of record) } \\
\hline$Q_{2}=1.97 C D A^{0.545} M C S^{1.19} C R^{-0.735}$ & 0.008 & 0.045 & 0.229 & 0.211 & 51.6 & 5.0 \\
\hline$Q_{5}=3.67 C D A^{0.570} C R^{-0.895} M C S^{1.32}$ & .008 & .037 & .210 & .192 & 46.3 & 8.1 \\
\hline$Q_{10}=4.93 C D A^{0.583} C R^{-0.937} M C S^{1.39}$ & .008 & .038 & .216 & .196 & 47.5 & 10.3 \\
\hline$Q_{25}=6.58 C D A^{0.597} M C S^{1.46} C R^{-0.946}$ & .010 & .044 & .233 & .211 & 51.5 & 12.3 \\
\hline$Q_{50}=7.84 C D A^{0.606} M C S^{1.50} C R^{-0.931}$ & .012 & .050 & .250 & .224 & 55.3 & 13.3 \\
\hline$Q_{100}=9.12 C D A^{0.613} M C S^{1.54} C R^{-0.905}$ & .014 & .057 & .266 & .239 & 59.6 & 13.9 \\
\hline$Q_{200}=10.4 C D A^{0.619} M C S^{1.57} C R^{-0.868}$ & .016 & .065 & .284 & .255 & 64.2 & 14.2 \\
\hline$Q_{500}=12.2 C D A^{0.626} M C S^{1.61} C R^{-0.809}$ & .018 & .076 & .307 & .276 & 70.5 & 14.5 \\
\hline
\end{tabular}

APPLICABLE RANGES OF VARIABLES: $\quad C D A \quad 6.78-4,450 ; \quad M C S \quad 7.1-46.3 ; \quad C R \quad 1.22-11.2$

NOTE: $M C S$ and $C R$ are data-scale dependent. 


\section{Big Blue River Region}

This region was developed from stations in the Big Blue River Basin, which includes parts of southeastern Nebraska and northeastern Kansas (figs. 1 and 8). It is the same as Beckman's Region 5 (1976, p. 10-11).

Equations for the Big Blue River Region (table 8) are based on data from 32 stations with at least 10 years of record and TDAs of 2.0 to $4,450 \mathrm{mi}^{2}$. The explanatory variables, $T D A$, average maximum soil slope $(M S S)$, and stream density $(S D)$ are significant for all equations. $S F$ is significant for all equations except $Q_{2}$, and TTP is significant only for $Q_{10}$ and smaller. Except for the $Q_{2}$ equation, SEEs are lower than Beckman's Region 5 equations (1976, p. 60), especially for equations $Q_{25}$ and larger.

\section{Application of Equations}

The applicability of each of the regional peak-flow frequency equations is limited to the range of values of the drainage-basin characteristics used to develop the equations. The minimum and maximum values of the characteristics used to develop the equations are listed in tables 2-8. For the best compatibility with the equations, drainage-basin characteristics should be determined using the same scale and type of data used in the development of the equations. The same method of quantification (GIS/Basinsoft) also should be used for the measurement of $M C S$ and $B S$. For equations that have different explanatory variables for the various frequencies, judgment must be used, because predicted peak flows may not always increase for successively larger frequencies. One approach might be to compute estimated peak-flow values from the equations for each recurrence interval and then plot the results on probability paper. A smoothed curve then could be drawn through the points, perhaps giving more influence to points with lower SEEs.

Table 8. Peak-flow equations for the Big Blue River Region

[AEYR, average equivalent years of record; AME, average model error; ASE, average sampling error; MSS, average maximum soil slope, in percent; $Q$, peak discharge, in cubic feet per second, for a given recurrence interval, in years; SEE, standard error of estimate; SEP, standard error of prediction; $S D$, stream density, in miles per square mile; $S F$, shape factor, dimensionless; TDA, total drainage area, in square miles; TTP, 2-year, 24-hour precipitation, in inches]

\begin{tabular}{|c|c|c|c|c|c|c|}
\hline \multirow[b]{2}{*}{ Estimation equation } & ASE & AME & SEP & SEE & \multirow{2}{*}{$\begin{array}{l}\text { SEE } \\
\text { (per- } \\
\text { cent) }\end{array}$} & \multirow[b]{2}{*}{$\begin{array}{c}\text { AEYR } \\
\text { (years) }\end{array}$} \\
\hline & \multicolumn{4}{|c|}{$\begin{array}{l}\text { (based on variables } \\
\text { in } \log _{10} \text { units) }\end{array}$} & & \\
\hline \multicolumn{7}{|c|}{ (32 stations with 10 or more years of record) } \\
\hline$Q_{2}=54.0 T D A^{0.627}(T T P-2)^{1.69} S D^{0.468} M S S^{0.425}$ & 0.007 & 0.027 & 0.185 & 0.164 & 39.1 & 4.9 \\
\hline$Q_{5}=160 T D A^{0.580} M S S^{0.492} S D^{0.533}(T T P-2)^{1.05} S F^{-0.220}$ & .004 & .006 & .103 & .079 & 18.4 & 19.6 \\
\hline$Q_{10}=267 T D A^{0.546} M S S^{0.534} S F^{-0.264} S D^{0.511}(T T P-2)^{0.790}$ & .004 & .002 & .075 & .044 & 10.2 & 49.7 \\
\hline$Q_{25}=463 T D A^{0.500} M S S^{0.618} S F^{-0.360} S D^{0.631}$ & .004 & .002 & .075 & .041 & 9.5 & 69.2 \\
\hline$Q_{50}=607 T D A^{0.491} M S S^{0.638} S F^{-0.372} S D^{0.617}$ & .005 & .002 & .081 & .045 & 10.3 & 71.2 \\
\hline$Q_{100}=764 T D A^{0.483} M S S^{0.656} S F^{-0.382} S D^{0.601}$ & .006 & .003 & .091 & .052 & 12.1 & 67.2 \\
\hline$Q_{200}=936 T D A^{0.477} M S S^{0.672} S F^{-0.389} S D^{0.584}$ & .006 & .004 & .101 & .061 & 14.1 & 61.8 \\
\hline$Q_{500}=1,190 T D A^{0.469} M S S^{0.692} S F^{-0.396} S D^{0.557}$ & .008 & .005 & .116 & .074 & 17.2 & 55.0 \\
\hline
\end{tabular}

APPLICABLE RANGES OF VARIABLES: TDA 2.03-4,450; TTP 2.62-3.35; SD 0.14-1.39; MSS $1.9-14.5$; SF $0.13-7.60$

NOTE: $S D$ is data-scale dependent. 


\section{Regulated Streams}

Peak-flow frequency analyses for stations on regulated streams in Nebraska with at least 10 years of regulated peak flows were done using program PEAKFQ based on Bulletin 17B guidelines and the log-Pearson Type III (LP3) distribution with skew coefficients derived only from each station's peakflow data. All available peak-flow records within the period of current regulated condition were used for these analyses; they are identified as "REG" under the type of analysis in table B2. For reaches of streams that include more than one station with at least 25 years of regulated record, approximate graphical relations of peak-flow frequency and distance upstream of the mouth also were developed. These relations are very generalized.

Graphical peak-flow frequency relations were developed for the Niobrara, North Platte, South Platte, Platte, and Republican Rivers, and for Salt, Antelope (not shown), Frenchman, and Red Willow Creeks (fig. 1). Peak-flow frequency values for 58 stations were plotted against distance, in miles, as measured upstream from the mouth along their respective streams. Only the 49 stations with at least 25 years of regulated record were used to develop approximate log-linear relations. The remaining stations, with less than 25 years of record, were used only for reference. The periods of the current regulated condition for each of these streams were identified and used to determine the period for which the peak-flow frequency analyses would be computed for each station (table 9). Each of the nine regulated streams is discussed separately in the following sections, and the locations of selected dams are shown on figures 1 and 9.

\section{Niobrara River}

The Niobrara River originates in Wyoming, flows through northern Nebraska, and drains as a right-bank tributary into the Missouri River in northeastern Nebraska. Major tributaries to the Niobrara include, in downstream order: Snake River, Minnechaduza Creek, and Keya Paha River. Values of $Q_{5}$ through $Q_{500}$ decrease measurably from the station at the Wyoming state line to the station at Agate and they increase from there to the station above Box Butte Reservoir (fig. 10) even for concurrent periods of record (data shown).
Patterson (1966, p. 410) noted that the peak flows at Agate are materially affected by diversions for irrigation; however, the ratios of irrigated acres to drainage area are nearly identical (8.0 to 10.4) for all three stations, with Agate actually having the smallest ratio (Boohar and others, 1992, p. 55-57). It is possible that the flow records for one or more of the stations is not representative of their longterm peak-flow characteristics, but the differences are so large that some additional explanation seems warranted. One possible explanation, or contributing factor, could be that the drainage basin narrows and the channel gradient decreases from the state line to Agate; this could result in significant attenuation of flows. Because of the uncertainty, no estimated relations between peak-flow frequency and distance from the mouth were developed for this reach of the Niobrara River.

Two major dams are located in the Niobrara River Basin-Box Butte on the mainstem and Merritt on the Snake River (table 9). Except for $Q_{2}$, Box Butte Dam causes large reductions in the peak flows downstream, especially as frequencies increase (fig. 10). The effects of the dam appear to diminish within about $70 \mathrm{mi}$ downstream of the dam. Merritt Dam appears to have little effect on the Niobrara River peak flows, especially considering its small reduction in peak flows for the Snake River itself (table B2).

\section{North Platte River}

The North Platte River originates in the mountains of northern Colorado and flows through the mountains and plains of Wyoming to its confluence with the South Platte River in western

Nebraska. There are four major dams on the North Platte River-Seminoe, Pathfinder, and Glendo, in Wyoming, and Kingsley in Nebraska (table 9). Glendo was the last of these dams built on the North Platte River, and it is the most downstream of the three Wyoming dams; therefore, its operational date of October 1957 was used as the beginning date of the current regulated condition of the North Platte River between Glendo and Kingsley Dams. The operational date of Kingsley Dam, February 1941, was used as the beginning date for stations downstream of Kingsley Dam because the large storage capacity of Lake McConaughy would be 
Table 9. Summary of regulation data for selected stream reaches

[Apr, April; Aug, August; Feb, February; Nov, November; Oct, October; Sept, September; POR, period of record]

\begin{tabular}{|c|c|c|c|}
\hline Stream name & Stream reach & $\begin{array}{l}\text { Period of } \\
\text { current } \\
\text { regulated } \\
\text { condition }\end{array}$ & Remarks $^{1}$ \\
\hline Niobrara & Wyoming state line to Box Butte Dam & Entire POR & Affected by irrigation during entire POR \\
\hline River & Box Butte Dam to Snake River & Oct $1945-$ & Box Butte Dam (1,460 mi², approximately; Oct 1945) \\
\hline (fig. 10) & Snake River to mouth & Feb 1964- & Merrit Dam (640 mi², approximately; Feb 1964) \\
\hline \multirow[t]{2}{*}{$\begin{array}{l}\text { North Platte } \\
\text { River } \\
\text { (fig. 11) }\end{array}$} & Wyoming state line to Kingsley Dam & Oct 1957- & $\begin{array}{l}\text { Affected by Seminoe (7,230 } \mathrm{mi}^{2} \text {, Apr 1939), Pathfinder } \\
\left(10,711 \mathrm{mi}^{2}, \text { Apr 1909), and Glendo }\left(15,545 \mathrm{mi}^{2} \text {, Oct 1957) }\right.\right. \\
\text { Dams in Wyoming }\end{array}$ \\
\hline & Kingsley Dam to mouth & Feb 1941- & Kingsley Dam (29,300 mi², approximately; Feb 1941) \\
\hline $\begin{array}{l}\text { South Platte } \\
\text { River } \\
\text { (fig. 12) }\end{array}$ & $\begin{array}{l}\text { South Platte River near Balzac, Colorado } \\
\text { to mouth }\end{array}$ & Entire POR & $\begin{array}{l}\text { Affected by transmountain and irrigation diversions, storage } \\
\text { reservoirs, power generation, and irrigation return flows } \\
\text { during entire POR; because of large amount of intervening } \\
\text { drainage area, Chatfield Dam }\left(3,018 \mathrm{mi}^{2}, \text { May 1975) assumed }\right. \\
\text { not to increase regulation significantly }\end{array}$ \\
\hline $\begin{array}{l}\text { Platte River } \\
\text { (fig. 13) }\end{array}$ & $\begin{array}{l}\text { Confluence of North and South Platte } \\
\text { Rivers to mouth }\end{array}$ & Feb 1941- & Effects of regulation much less below Loup River \\
\hline \multirow[t]{3}{*}{$\begin{array}{l}\text { Salt Creek } \\
\text { (fig. 14) }\end{array}$} & Hickman Branch to Cardwell Branch & $1965-$ & $\begin{array}{l}\text { Olive Creek Lake }\left(8.2 \mathrm{mi}^{2}, 1964\right), \text { Bluestem Lake }\left(16.6 \mathrm{mi}^{2} \text {, }\right. \\
\text { 1963), Wagon Train Lake }\left(15.6 \mathrm{mi}^{2}, 1963\right) \text {, and Stagecoach } \\
\text { Lake }\left(9.2 \mathrm{mi}^{2}, 1964\right) \text { Dams }\end{array}$ \\
\hline & Cardwell Branch to Oak Creek & $1966-$ & $\begin{array}{l}\text { Yankee Hill Lake }\left(8.4 \mathrm{mi}^{2}, 1965\right) \text {, Conestoga Lake }\left(15.1 \mathrm{mi}^{2} \text {, }\right. \\
\text { 1964), Pawnee Lake }\left(35.9 \mathrm{mi}^{2}, 1965\right) \text {, East and West Twin } \\
\text { Lakes }\left(11.0 \mathrm{mi}^{2}, 1965\right) \text {, and Holmes Lake }\left(5.4 \mathrm{mi}^{2}, 1962\right) \\
\text { Dams }\end{array}$ \\
\hline & Oak Creek to mouth & $1968-$ & Branched Oak Lake Dam $\left(88.7 \mathrm{mi}^{2}, 1967\right)$ \\
\hline $\begin{array}{l}\text { Antelope } \\
\text { Creek } \\
\text { (fig. 14) }\end{array}$ & Holmes Lake Dam to mouth & $1962-$ & Holmes Lake Dam $\left(5.4 \mathrm{mi}^{2}, 1962\right)$ \\
\hline $\begin{array}{l}\text { Republican } \\
\text { River }\end{array}$ & $\begin{array}{l}\text { South Fork Republican River to Trenton } \\
\text { Dam }\end{array}$ & July $1950-$ & Bonny Dam $\left(1,820 \mathrm{mi}^{2}\right.$, approximately; July 1950$)$ \\
\hline (fig. 15) & $\begin{array}{l}\text { Trenton Dam to Frenchman Creek } \\
\text { Frenchman Creek to Red Willow Creek } \\
\text { Red Willow Creek to Medicine Creek } \\
\text { Medicine Creek to Harlan County Dam } \\
\text { Harlan County Dam to Kansas state line }\end{array}$ & $\begin{array}{l}\text { May } 1953- \\
\text { May } 1953- \\
\text { Sept } 1961- \\
\text { Sept } 1961- \\
\text { Nov } 1952-\end{array}$ & $\begin{array}{l}\left.\text { Trenton Dam (8,620 mi }{ }^{2} \text { approximately; May } 1953\right) \\
\text { Enders Dam }\left(950 \mathrm{mi}^{2}, \text { approximately; Oct } 1950\right) \\
\text { Red Willow Dam }\left(730 \mathrm{mi}^{2}, \text { approximately; Sept } 1961\right) \\
\text { Medicine Creek Dam }\left(880 \mathrm{mi}^{2}, \text { approximately; Aug } 1949\right) \\
\text { Harlan County Dam (20,750 mi }{ }^{2} \text {, approximately; Nov 1952) }\end{array}$ \\
\hline Frenchman & Colorado state line to Enders Dam & Entire POR & Affected by irrigation during entire POR \\
\hline $\begin{array}{c}\text { Creek } \\
\text { (fig. 16) }\end{array}$ & Enders Dam to mouth & Oct $1950-$ & Enders Dam (950 $\mathrm{mi}^{2}$, approximately; Oct 1950$)$ \\
\hline $\begin{array}{l}\text { Red Willow } \\
\text { Creek } \\
\text { (fig. 16) }\end{array}$ & Above Red Willow Dam & Entire POR & $\begin{array}{l}\text { Peak flows do not appear to be affected substantially by } \\
\text { irrigation development although natural streamflow is affected } \\
\text { Red Willow Dam }\left(730 \mathrm{mi}^{2} \text {, approximately; Sept } 1961\right)\end{array}$ \\
\hline
\end{tabular}

\footnotetext{
${ }^{1}$ For dams, numbers in parentheses are drainage area and beginning date of operation.
} 


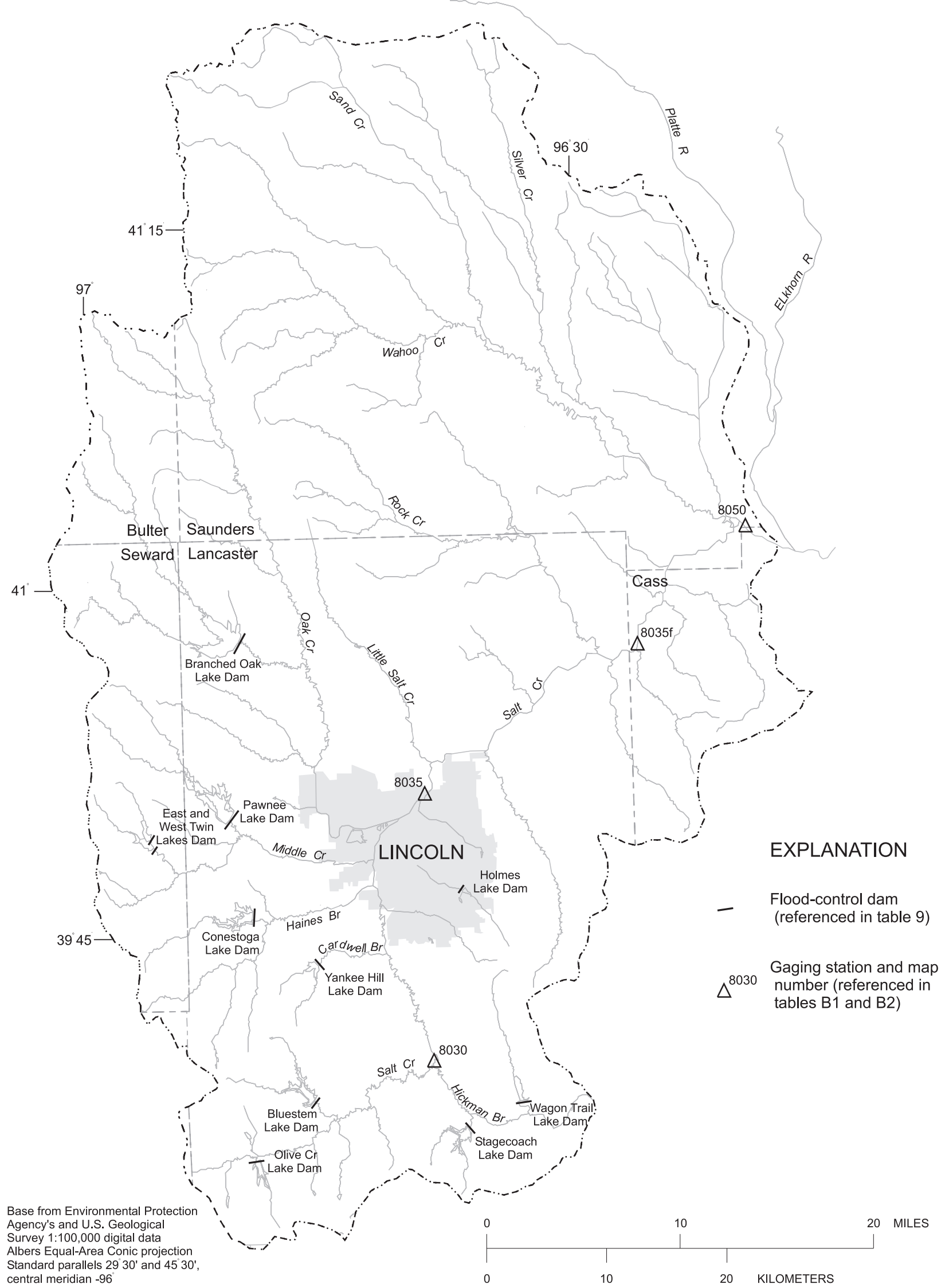

Figure 9. Location of flood-control dams in the Salt Creek drainage basin and of streamflow-gaging stations along the mainstem of Salt Creek. 


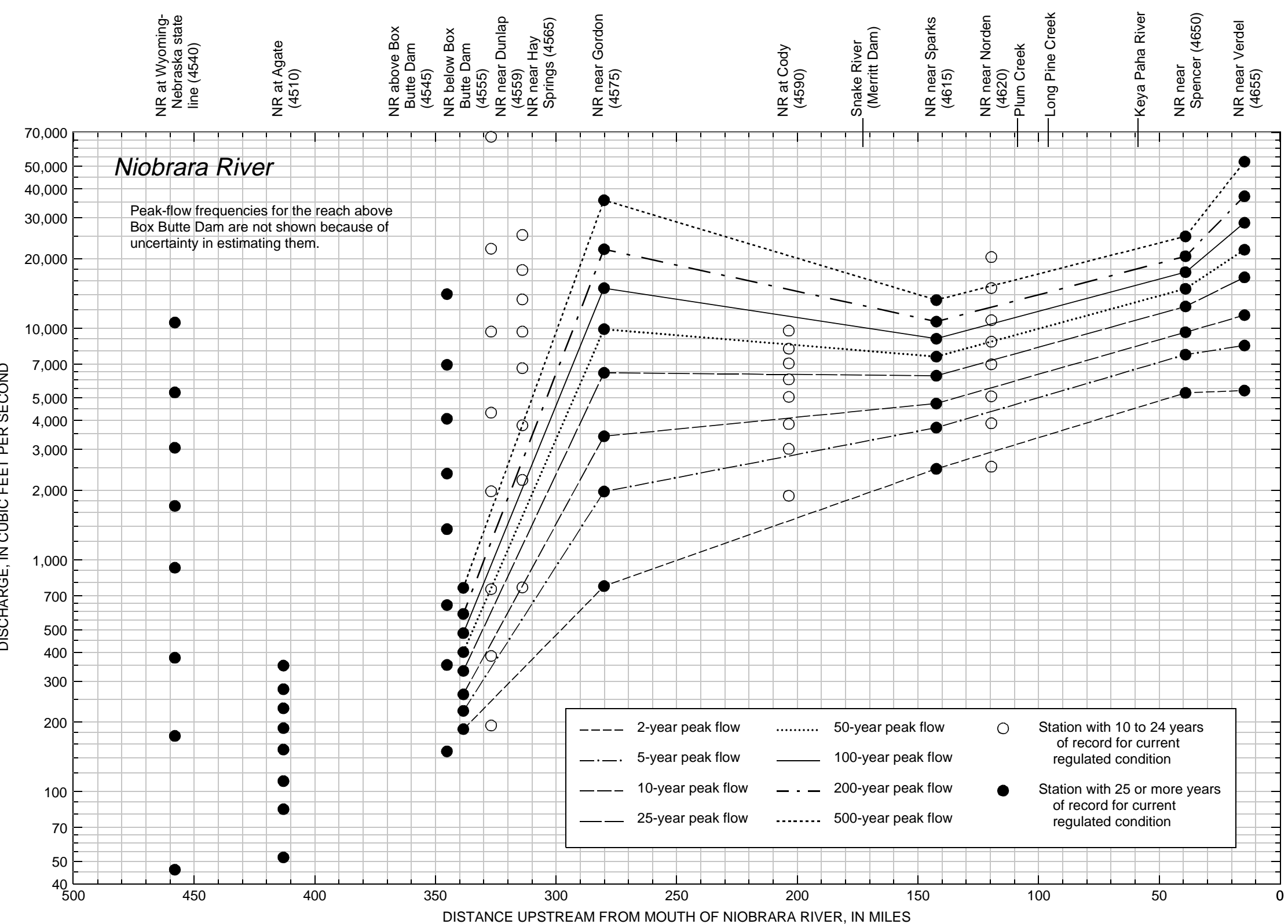

Figure 10. Peak-flow frequencies for the current regulated condition of the Niobrara River (NR) in Nebraska estimated from streamflow-gag ing station data (number following station name is map number referred in tables B1 and B2). 
expected to mask the effects of the operation of Glendo Dam that began in 1957. Peak-flow frequency relations for the North Platte River downstream of the Wyoming-Nebraska state line are fairly uniform, with a noticeable reduction in peak flows downstream of Kingsley Dam (fig. 11).

\section{South Platte River}

The South Platte River originates in the mountains of central Colorado and flows across the plains to its confluence with the North Platte River in western Nebraska. Regulation of the South Platte River began prior to collection of streamflow records. Reservoir storage created by dams in the South Platte River Basin is less than in the North Platte River Basin (Eschner and others, 1983, page A6). Chatfield, the largest dam in the South Platte River Basin, began operation in May 1975. Because Chatfield Dam is located near the upstream end of the basin and controls less than 13 percent of the drainage area upstream of Nebraska, it was assumed that its affect on peak flows in Nebraska was minimal. Therefore, the entire periods of record were used for South Platte River stations. Peak-flow frequency relations decrease in the downstream direction, generally with only small increases for several frequencies from South Platte River at Paxton (7650) to South Platte River at North Platte (7655) (fig. 12).

\section{Platte River}

The Platte River begins at the confluence of the North and South Platte Rivers in western Nebraska and drains into the Missouri River as a right-bank tributary in eastern Nebraska. In addition to the mainstem Platte River stations, peakflow frequency values were computed for Wood River near Alda (7720), Loup River at Columbus (7945), Elkhorn River at Waterloo (8005), and Salt Creek at Ashland (8050) to estimate each tributary's effect on Platte River peak flows. Wood River peak flows were relatively small, but the peak flows for the Loup River were larger than those estimated graphically for the Platte River just upstream of the mouth of the Loup River. Therefore, the peak-flow values for the Loup River are used for the Platte River mainstem at their junction; this results in a discontinuity in the plots at that point (fig. 13). The peak-flow frequency values for the Platte River above and below the Elkhorn River (also a discontinuity on fig. 13) were extrapolated from the values for the Platte River at North Bend (7960) based on respective estimated drainage areas. The effect of Salt Creek could not be determined reliably. Although Kingsley Dam appears to have little effect on the peak-flow frequency values of the Platte River below the Loup River, for consistency, none of the Platte River stations were analyzed for periods prior to the Kingsley Dam operational date of February 1941.

\section{Salt and Antelope Creeks}

Salt Creek originates in southeastern Nebraska and flows north and northeast through Lincoln before draining into the Platte River in northwestern Cass County (fig. 9). The upper basin is fan shaped with a number of tributaries converging with the main stream in or near Lincoln, including Antelope Creek (not shown), which flows northwest through the middle of Lincoln. After two large floods in the early 1950s, a series of flood-control dams were constructed on several streams around Lincoln (table 9). Peak-flow frequency analyses for periods since regulation began were computed for three stations on Salt Creek and for three stations on Antelope Creek (fig. 14). Olive Creek, Bluestem Lake, Wagon Train Lake, and Stagecoach Lake Dams are located upstream of Salt Creek at Roca (8030). Yankee Hill Lake, Conestoga Lake, Pawnee Lake, East and West Twin Lakes, Holmes Lake, and Branched Oak Lake Dams are located downstream of Roca and upstream of Salt Creek at Lincoln (8035). Holmes Lake Dam is located upstream of the three Antelope Creek stations (not shown). The peak-flow frequency relations for both Salt and Antelope Creeks increase in the downstream direction with the exception of $Q_{500}$ on the upper reach of Antelope Creek, which decreases slightly (fig. 14).

\section{Republican River}

The Republican River Basin is in parts of three states-Colorado, Nebraska, and Kansas. The Republican River begins at the confluence of the North Fork Republican and the Arikaree Rivers, both of which originate in Colorado. It then flows through southern Nebraska, and joins the Smoky 


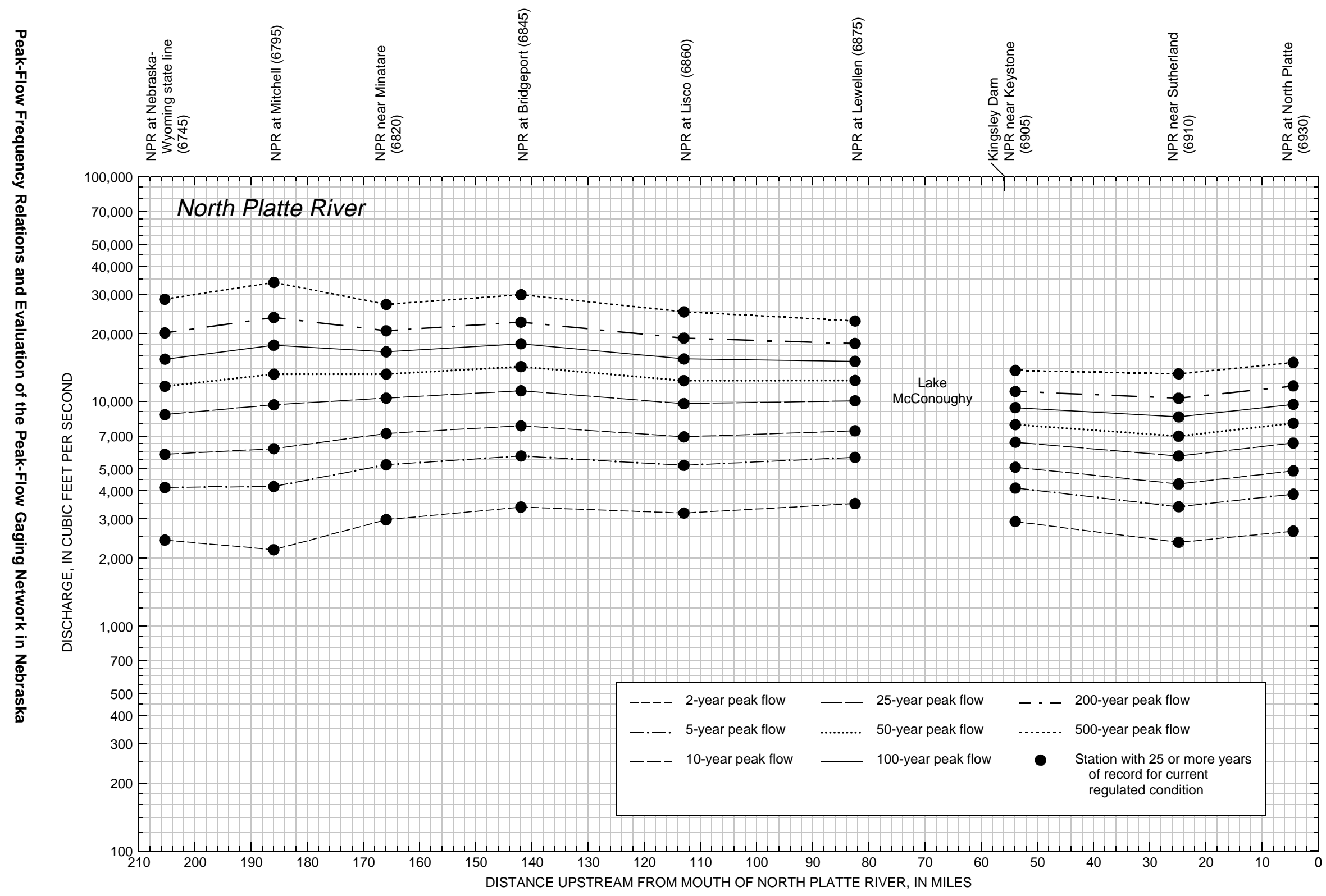

Figure 11. Peak-flow frequencies for the current regulated condition of the North Platte River (NPR) in Nebraska estimated from streamflow-gaging station data (number following station name is map number referred in tables B1 and B2). 


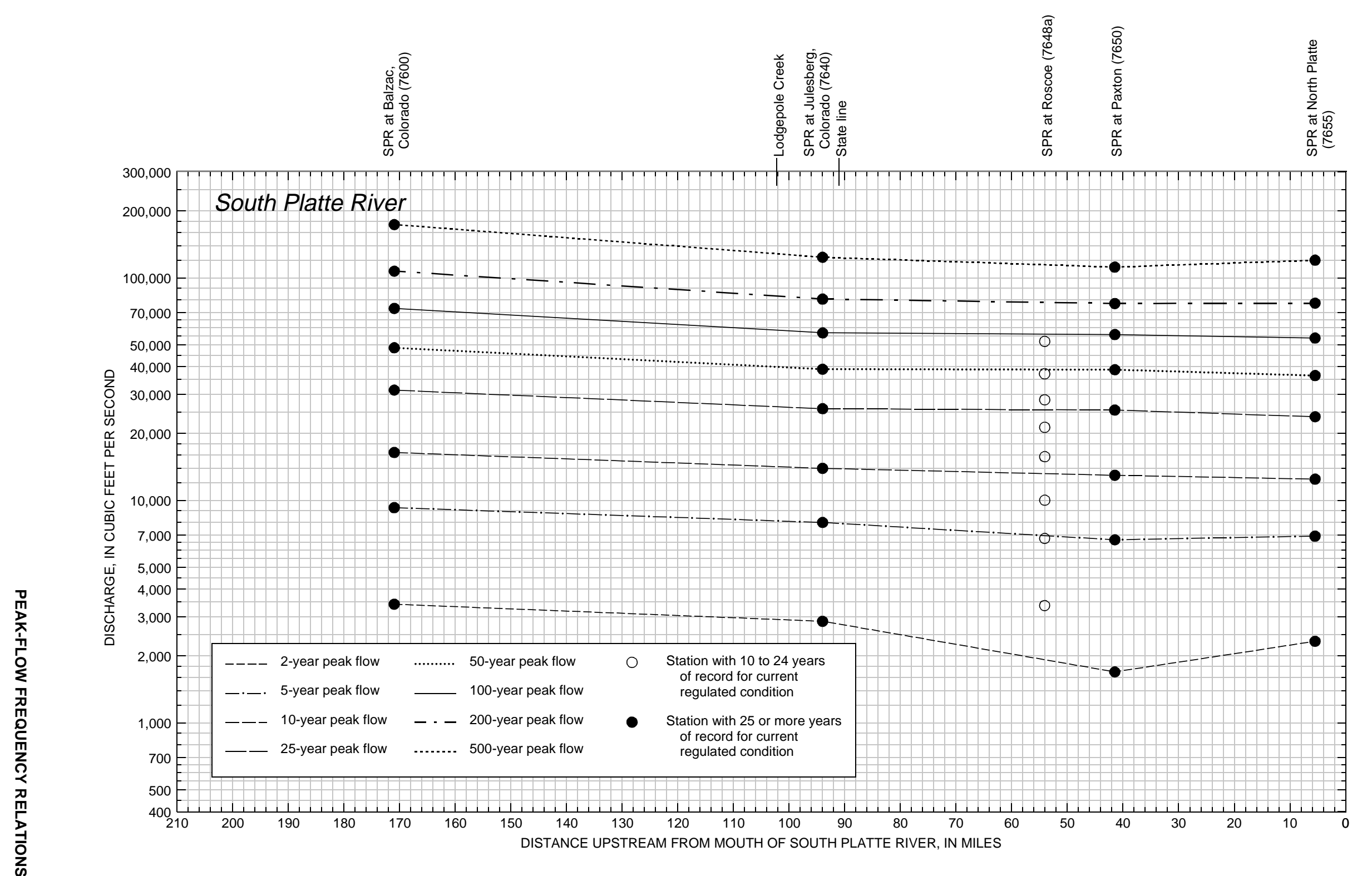

Figure 12. Peak-flow frequencies for the current regulated condition of the South Platte River (SPR) in Nebraska and part of Colorado estimated from streamflow-gaging station data (number following station name is map number referred in tables B1 and B2). 


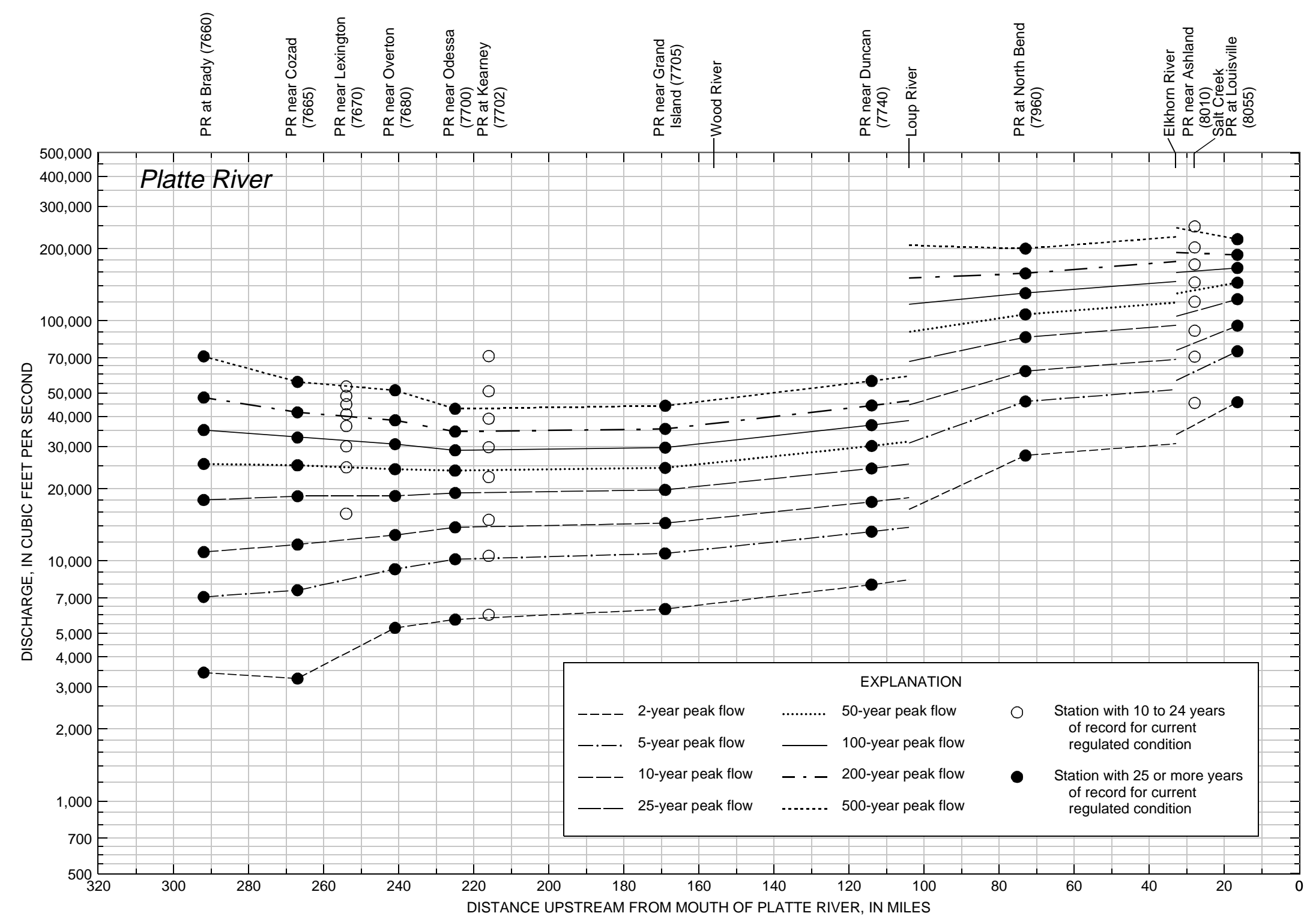

Figure 13. Peak-flow frequencies for the current regulated condition of the Platte River (PR) in Nebraska estimated from streamflow-gaging station data (number following station name is map number referred in tables B1 and B2). 


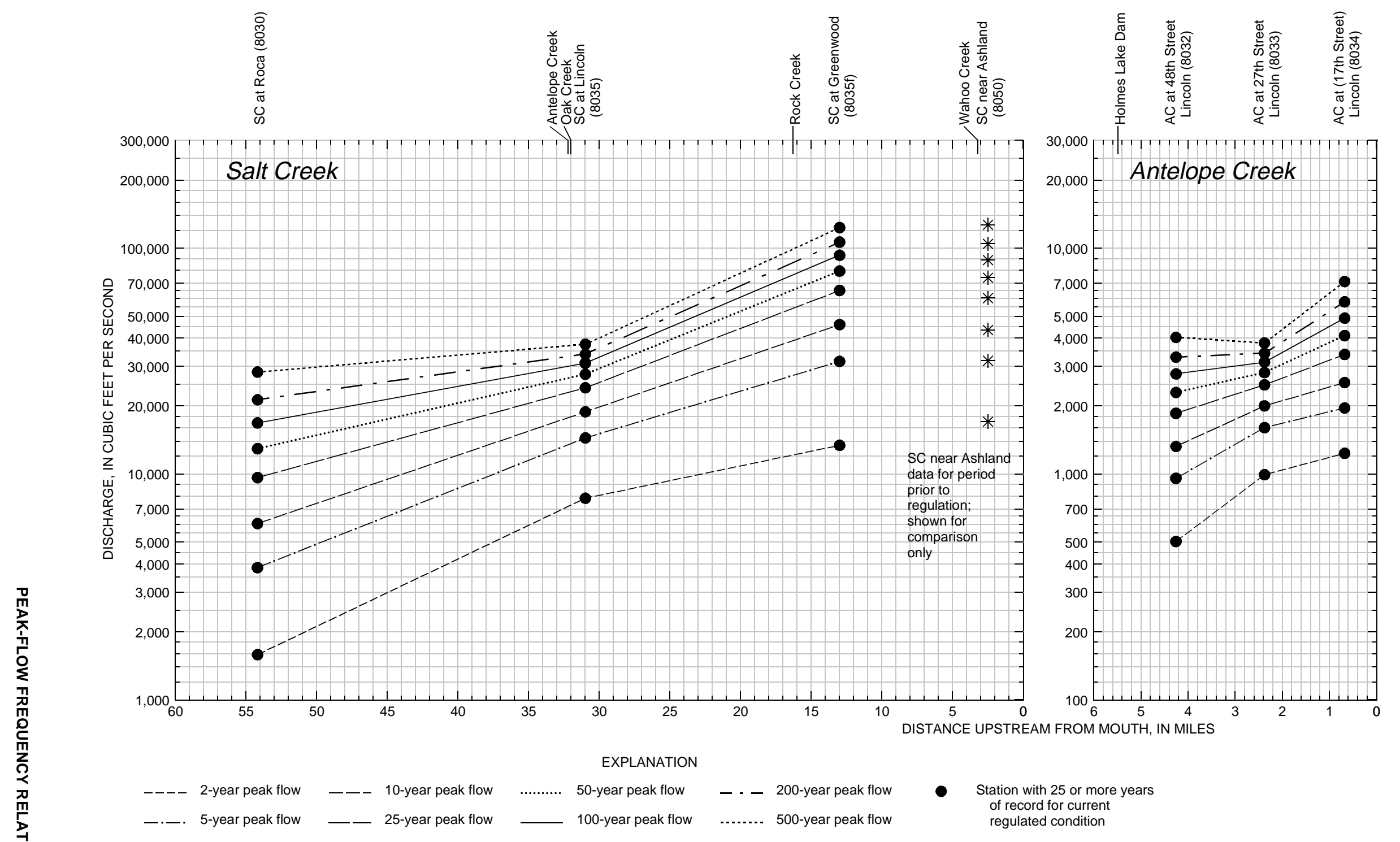

Figure 14. Peak-flow frequencies for the current regulated conditions of Salt (SC) and Antelope Creeks (AC) in Lancaster, Cass, and Saunders Counties of Nebraska estimated from streamflow-gaging station data (number following station name is map number referred in tables B1 and B2). 
Hill River to form the Kansas River in north-central Kansas. Two mainstem dams and five tributary dams have been constructed in the Republican River Basin upstream of the Nebraska-Kansas state line. The operational dates for Bonny, Trenton, Enders, Red Willow, Medicine Creek, and Harlan County Dams and their effects on the period of current regulated condition were determined (table 9). Norton Dam is not listed because Prairie Dog Creek, on which it is located, flows directly into Harlan County Lake below which the effects of Norton Dam are masked because of Harlan County Lake's relatively large storage capacity. Analyses for eight mainstem stations were used in estimating peak-flow frequency relations for the Republican River (fig. 15).

The operational date of July 1950 for Bonny Dam on the South Fork of the Republican River in northeastern Colorado was used as the beginning date of the current regulated condition for the South Fork below Bonny Dam and for the Republican River mainstem between the mouth of the South Fork and Trenton Dam farther downstream. Considering the amount of intervening drainage area, the effect of Bonny Dam on most peak flows into Nebraska is probably not very significant. However, it could have had a significant effect, had it existed, on the very large flood of 1935 because much of the flow for that flood originated in the upper part of the basin. See the maximum peak flows for South Fork Republican River near Idalia, Colorado (8250) and Republican River at Max (8280) in table B2.

The peak-flow frequency values for the Republican River above Trenton Dam were extrapolated from those for Republican River at Stratton (8285) based on respective drainage areas. Peak-flow values for the Republican River below Sappa Creek were based on the larger of those computed for Sappa Creek near Stamford (8475) and those for Republican River near Orleans (8445) extrapolated for the increased drainage area from Sappa Creek. The peakflow values for the Republican River above Harlan County Dam were extrapolated from the values below Sappa Creek, previously described, based on drainage areas.

Trenton and Harlan County Dams cause large reductions in Republican River peak flows, and Enders Dam on Frenchman Creek probably contributes to the decreases in $Q_{200}$ and $Q_{500}$ between the Republican River stations at Trenton (8295) and at
McCook (8370) (fig. 15). There are discontinuous increases in peak flows at the junction with Sappa Creek, especially at the larger frequencies. Elsewhere, peak-flow frequency relations increase in the downstream direction with the exception of $Q_{500}$ and $Q_{200}$ between the stations at Guiderock (8530a) and near Hardy (8535), where they decrease slightly.

\section{Frenchman Creek}

Frenchman Creek originates in northeastern Colorado and drains as a left-bank tributary into the Republican River in southwestern Nebraska. Irrigation has affected flows in Frenchman Creek since before streamflow gaging began and the entire periods of record were used to compute peak-flow frequency analyses for stations above Enders Dam, the only major dam on Frenchman Creek. The operational date of October 1950 for Enders Dam was used for the beginning date of analyses for stations downstream of the dam. In addition to the Frenchman Creek stations (fig. 16), peak-flow frequency values were computed for Stinking Water Creek near Palisade (8350) to estimate its effect on Frenchman Creek values.

Enders Dam causes reductions in peak flows for $Q_{10}$ through $Q_{500}$, with increasingly larger reductions for the larger frequencies (fig. 16). Peak flows increase in the downstream direction below the dam, except for $Q_{2}$ between the junction with Stinking Water Creek and Frenchman Creek at Culbertson (8355), which decreases slightly.

\section{Red Willow Creek}

Red Willow Creek originates in southwestern Nebraska and flows to the southeast before draining as a left-bank tributary into the Republican River. Red Willow Dam is the only major dam on the creek. Its operational date of September 1961 was used as the beginning date for peak-flow frequency analyses of the two stations located downstream of the dam (fig. 16). For comparison, the peak-flow frequency values for an unregulated station, Red Willow Creek above Hugh Butler Lake (8373) located upstream of the dam, also are included on figure 16. 


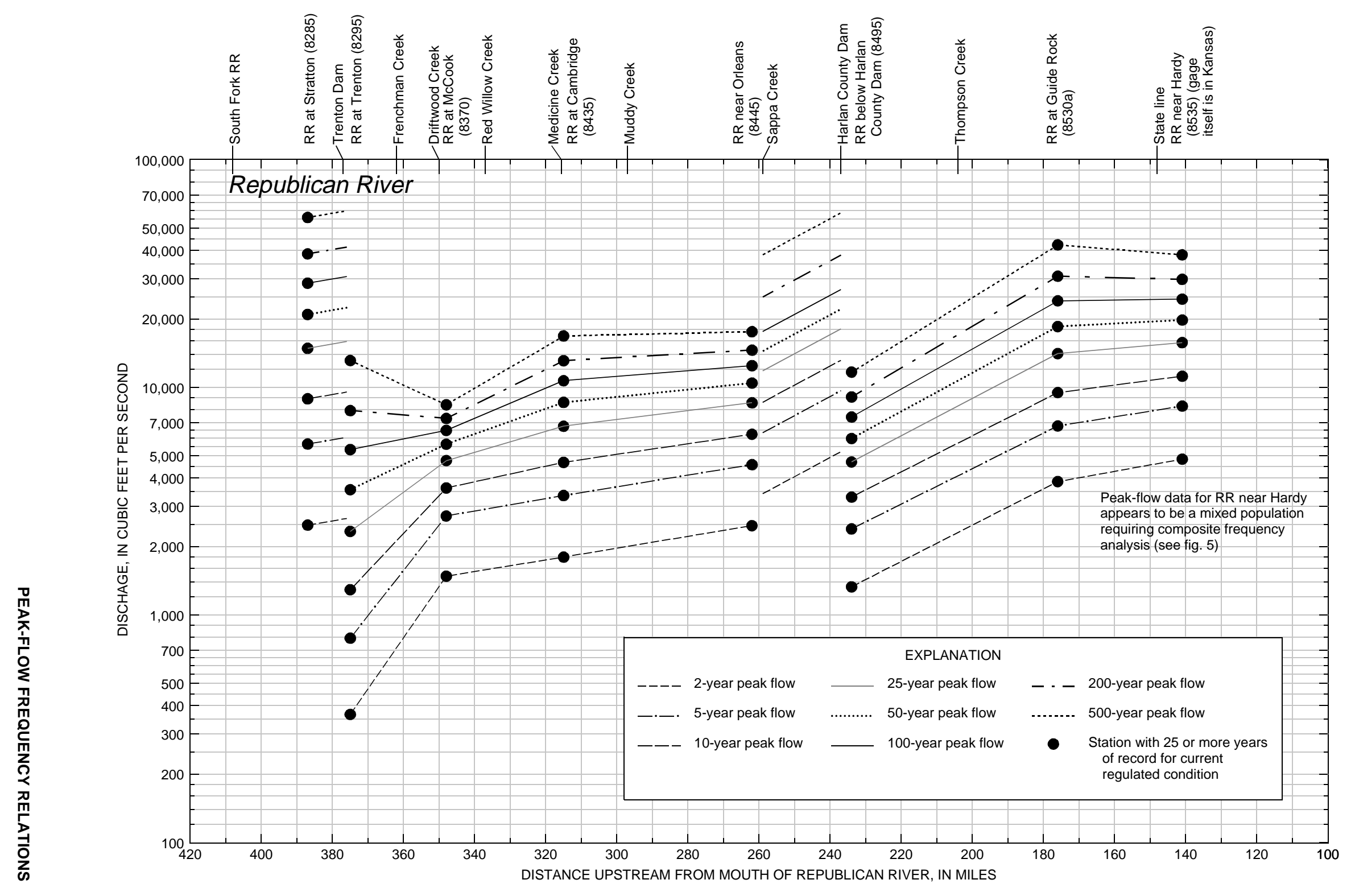

Figure 15. Peak-flow frequencies for the current regulated condition of the Republican River (RR) in Nebraska and part of Kansas estimated from streamflow-gaging data (number following station name is map number referred in tables B1 and B2). 


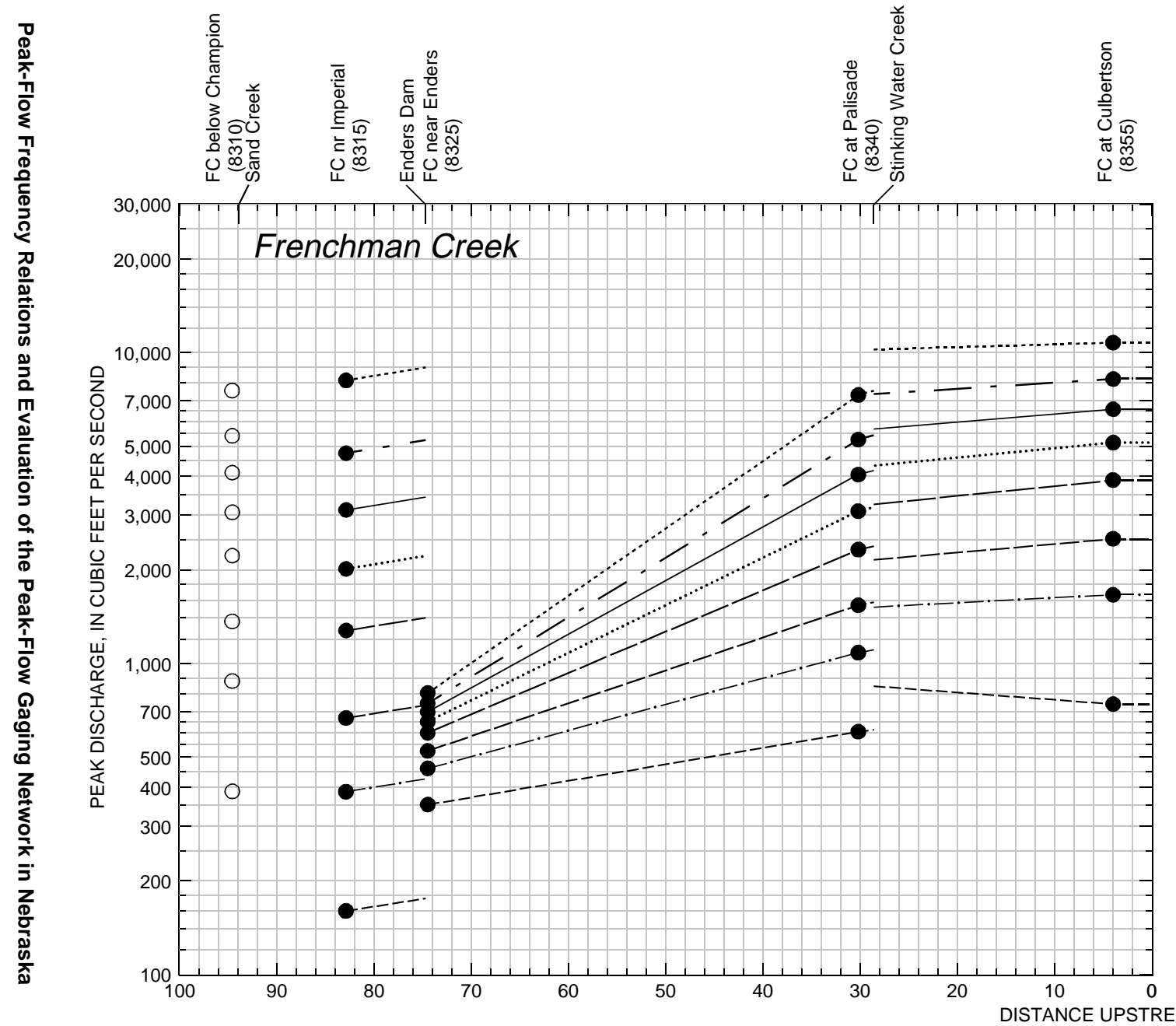

EXPLANATION

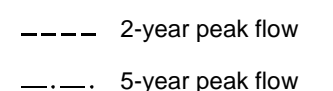
10-year peak flow 50-year peak flow

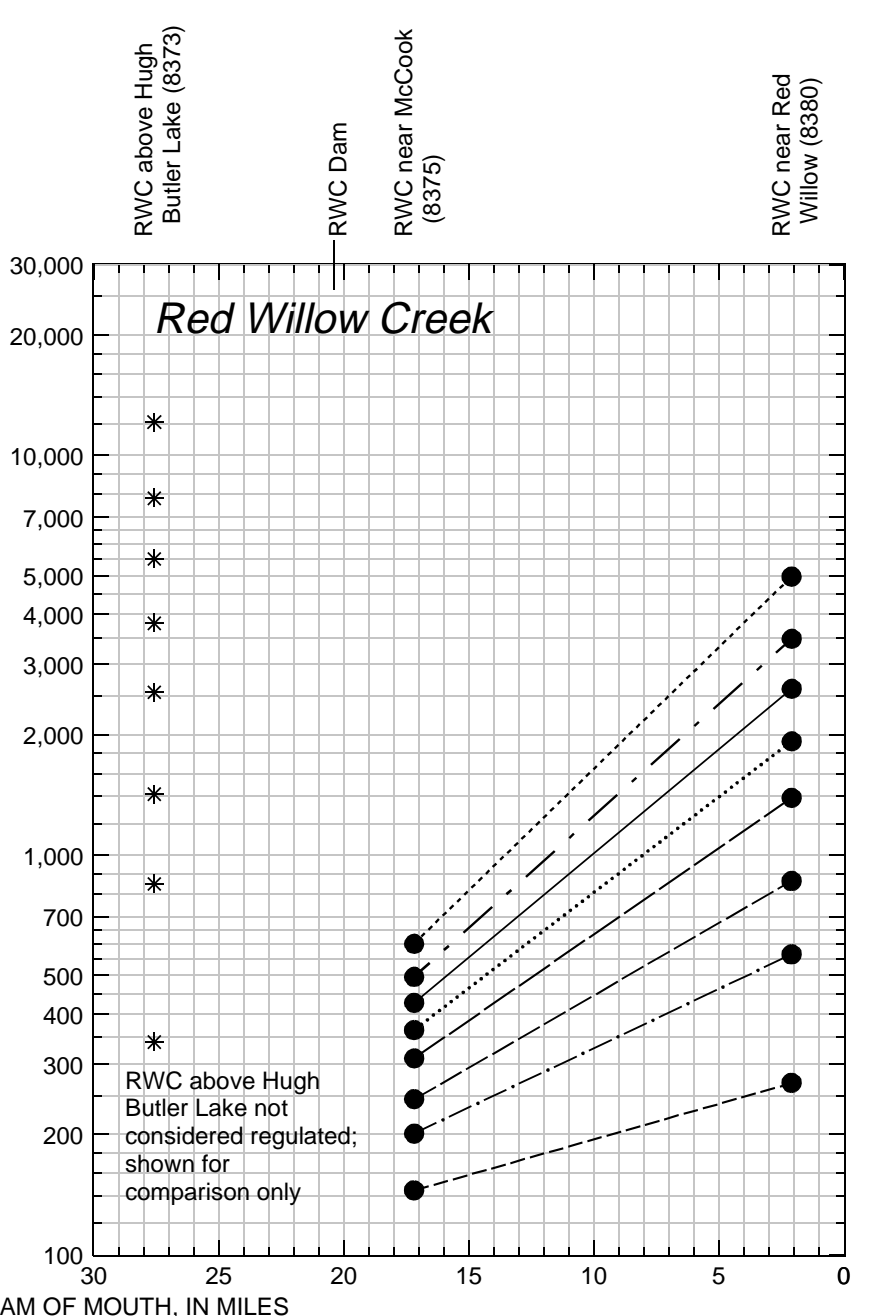

- . 200-year peak flow

o

- Station with 25 or more years of record for condition

Figure 16. Peak-flow frequencies for the current regulated conditions of Frenchman (FC) and Red Willow (RWC) Creeks in Nebraska estimated from streamflow-gaging station data (number following station name is map number referred in tables B1 and B2). 
Red Willow Dam causes large reductions in peak flows compared to the unregulated flows upstream. In the downstream direction below the dam, peak flows increase.

\section{NETWORK EVALUATION}

For each peak-flow frequency region, statistical analyses were done to estimate how additional years of peak-flow data might affect the average sampling errors (ASEs) of the newly developed 100-year frequency (recurrence interval) equations. Four different scenarios were evaluated-10- and 20 -year periods of additional data collection (planning horizons) with "equation" stations (those stations used in the development of the equations) and 10- and 20-year planning horizons with "equation" stations plus with new stations. Output for the various scenarios for each region can be compared to determine where the largest reduction in ASE of the newly developed peak-flow frequency equations could be gained for the least amount of new data collection, and hence for the least cost.

\section{Station Selection}

Three types of stations were identified and used for the network analyses of a particular regional equation: active, inactive, and new. Active stations were "equation" stations that were still being operated as of 1994. For analytical purposes, it was assumed that they would continue to be operated for the planning horizons with existing basenetwork funds. Inactive stations were "equation" stations that had been discontinued by 1994; it was assumed that they would be operated for the planning horizons but only with new discretionary funds. "New" stations could be completely new stations with no peak-flow record available or they could be stations with some record but not enough to have been used in the development of the equations. In either case, it was assumed they would be operated for the planning horizons but only with new discretionary funds.

The future operation of "new" stations would not only provide additional peak-flow data for updating the regional equations, but potentially could increase the range of the explanatory variables in the regional equation, thereby broadening the applicability of the equations. Before the effects of any "new" stations could be analyzed, their latitude and longitude needed to be known or determined along with values of the explanatory variables that had been used in the development of the equation being evaluated. With the exception of the Eastern and Big Blue River Regions, stations with 10 to 14 years of record were not used in the development of regional peak-flow frequency equations (tables 2-8). However, because basin characteristics already had been determined for most stations with 10 to 14 years of record, they were used as the "new" stations for the network analyses. The special nature of the composite equations prevented their evaluation by the network analysis program for any of the "new" station scenarios.

\section{Analyses and Output}

To do the network analyses, output from the GLS (regression) part of the GLSNET program that had been used to compute a particular peak-flow frequency equation was input to the NET program of GLSNET. The stations used in the development of the equation were flagged as either active or inactive. The NET program then was run for each of the planning horizons being considered (10 and 20 years). For the other two scenarios, data for any "new" stations within the region were input, and the program was run again for the two planning horizons.

For each scenario, the expected ASE of the equation was computed first by NET assuming that all available stations had been operated for the given planning horizon. Then the discretionary station that would cause the ASE to increase the least if it were not operated for the planning horizon was identified and removed from the data set, and the ASE was recomputed. This process was repeated internally within NET until only the active stations remained. For each scenario, the output from the NET analysis was used to produce a plot of the number of stations in relation to the ASE (figs. 17 and 18). The analyses that include "new" stations are unique for those sets of stations; a different set of "new" stations would produce different results. Therefore, those analyses should be considered only examples of, not accurate determinations of, how "new" stations would affect the ASEs. 


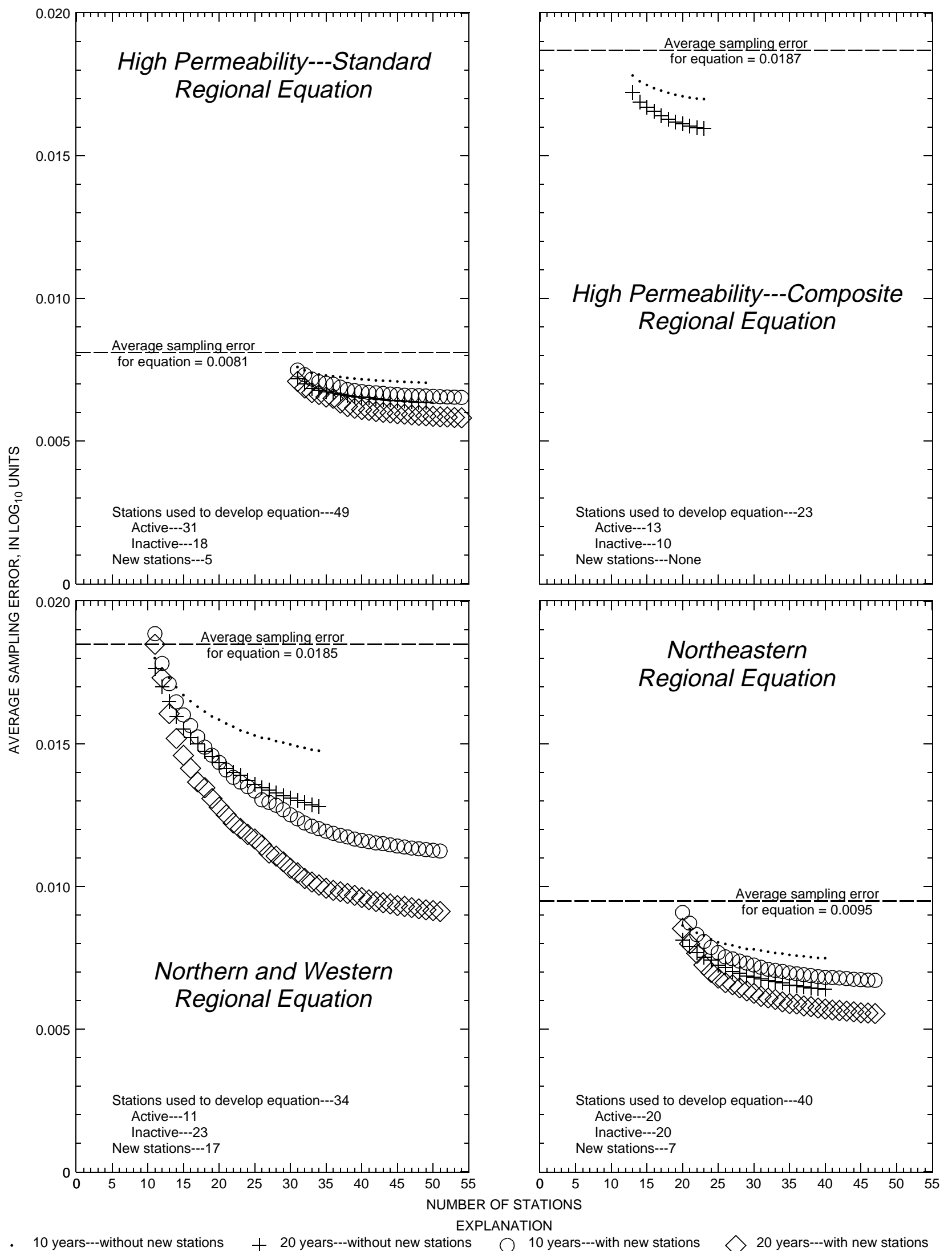

Figure 17. Results of network analyses for 10- and 20-year planning horizons for High-Permeability-Standard, High Permeability-Composite, Northern and Western, and Northeastern regional 100-year peak-flow-frequency equations. 


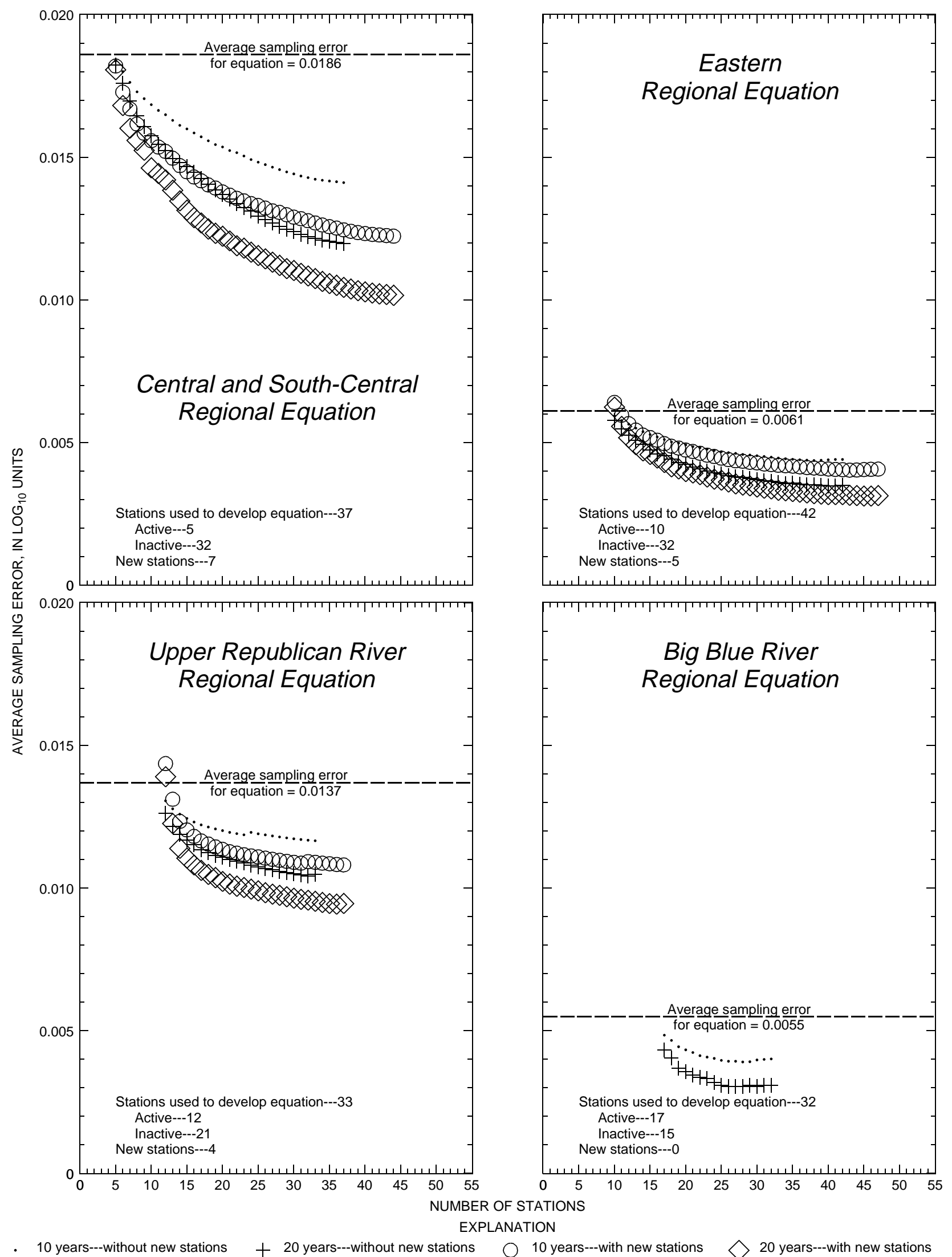

Figure 18. Results of network analyses for 10- and 20-year planning horizons for Central and South-Central, Eastern, Upper Republican River, and Big Blue River regional 100-year peak-flow-frequency equations. 


\section{Discussion of Results}

For each of the plots (figs. 17 and 18), the point associated with the smallest number of stations represents the ASE with only the active or base-network stations being operated for the various scenarios. The second point represents the ASE with one discretionary station being operated, the one that most reduces the ASE for that scenario. The effect of that station is actually the difference in ASE of the two points. The points associated with the largest number of stations for each plot represent the ASEs with all discretionary stations being operated for the various scenarios. For scenarios with "new" stations, the first stations included after the base-network stations were, in all cases, the "new" stations. The results illustrate that collecting data at "new" stations in a region probably would reduce the ASE for that region's peak-flow equations more than would collecting the same amount of data at stations that are inactive but that were used in the development of the regional equation.

Note that the ASEs for the active stations only are not the same for scenarios with and without "new" stations, even for the same planning horizon. In most cases, the ASEs actually are larger for the scenarios with "new" stations. This is because NET covers the entire range of basin characteristics, including those of the possible "new" stations, even before the assumed benefits of data from those "new" stations have been incorporated into the analysis. The updated equations would be applicable over a broader range of characteristics than the existing equations, but the ASE could be larger until data actually were available from those stations that had broadened the range of the characteristics.

Based on the plots, it appears that the Northern and Western, and Central and South-Central regional equations, which have the second and third largest ASEs, would benefit the most from additional discretionary peak-flow data, especially if collected at "new" stations. The High-Permeability-Standard, Eastern, and Big Blue River regional equations probably would benefit the least from additional discretionary peak-flow data. Although not directly apparent from the plots, "new" data that could be provided by additional composite analyses for existing stations probably would be of considerable benefit for the High-Permeability-Composite equa- tion, which had the largest ASE and the smallest number of stations of all the regional equations.

Based on the results, data from new stations, rather than more data from stations used to develop the regional peak-flow frequency equations, probably would most reduce the ASE of the equations.

\section{SUMMARY AND CONCLUSIONS}

Estimates of peak-flow magnitude and frequency are required for the efficient design of structures that convey flood flows, such as bridges and culverts, or of structures that occupy floodways, such as roads. In the fall of 1994, a cooperative study was begun by the Nebraska Department of Roads and the U.S. Geological Survey (USGS) to update peakflow frequency analyses for selected streamflowgaging stations, develop a new set of peak-flow frequency relations for ungaged streams, and evaluate the peak-flow gaging-station network for Nebraska. Using a geographic information system (GIS) and digital spatial data, drainage-basin characteristics - many of which were previously undefined for Nebraska - were quantified. Regional equations relating drainage-basin characteristics to peak-flow frequency characteristics were developed using a generalized least-squares (GLS) regression program. An evaluation of each of the regional gaging-station networks also was made to estimate how additional peak-flow data might reduce average sampling errors (ASEs) of future equations.

Twenty-seven morphometric characteristics were quantified using Basinsoft, a computer program developed by the USGS. Four soil characteristics were quantified using ARC/INFO. Two precipitation characteristics were quantified using ARC/INFO. Manual measurements and calculations were made to verify computer-quantified values for selected drainage basins.

Peak-flow frequency analyses were done for unregulated streamflow-gaging stations with at least 10 years of annual peak-flow record through 1993 and located in or within about 50 miles of Nebraska using the log-Pearson Type III (LP3) frequency distribution and the guidelines in Bulletin 17B of the Interagency Advisory Committee on Water Data. Two sets of standard analyses were made. The first set of standard analyses for unregulated streams was done using skew coefficients derived only from each station's peak-flow data. These station skews then 
were used to develop generalized skew relations. The second set of standard analyses was done using station skews weighted with generalized skews from the new skew relations. One set of standard analyses, using station skews only, was done for stations on regulated streams. Adjustments were made to peak-flow frequency analyses, as appropriate, for historic data and high and low outliers. Experience of the authors showed that the statistical tests for low outliers included in Bulletin 17B were not well suited for detecting multiple outliers. Therefore, adaptations of the existing procedure, other tests, and considerable judgment were used to identify and censor low outliers in these situations.

Regional equations relating generalized skew coefficients to basin characteristics were developed for most of the state, and a statewide map of generalized skew coefficients for basins with relatively low average permeability also was developed. Station skew coefficients were computed for stations in or within about 50 miles of Nebraska that, generally, had 25 years or more of unregulated peak flows. Several stations with as few as 18 peak flows were used where data were lacking. After other adjustments had been made, stations with identified high outliers were analyzed further to estimate how sensitive the station skew coefficients were to the high outliers. As a result, some stations were eliminated from further consideration in the development of skew relations.

An equation to estimate skew was developed first for basins with average permeability of the 60 -inch soil profile (P60) of more than 2.5 inches per hour. A skew map of the state then was developed for basins with $P 60$ less than 4 inches per hour, except for the Elkhorn River Basin where all basins were included. Regional equations, based on geographic areas, also were developed; those with mean-square errors (MSEs) less than those for the new skew map were adopted. The standard error of estimate (SEE) of the statewide skew map is 0.24. This compares to 0.78 for the Nebraska part of the National skew map and to 0.59 for the map developed by Cordes (1993), both of which include the high-permeability sandhills areas. SEEs for the skew equations ranged from 0.13 to 0.23 . The equations were developed using multiple-regression analyses; residuals from the analyses were used to define regions and to determine the best combination of explanatory variables that were reasonable hydrologically.

An alternative set of peak-flow frequency analyses were computed for selected stations using a conditional probability method suggested by William Kirby (USGS). Peak-flow frequency curves for most of the high-permeability stations appeared to indicate a pattern of different characteristics for the larger peak flows. Because of the relatively high permeabilities and large amounts of noncontributing drainage area in typical sandhills terrain, it was theorized that most of the smaller peak flows primarily were interflow and baseflow and that the larger peak-flows included a significantly greater proportion of surface runoff. Plots of peak flow compared to the 1- or 2-day lag of daily flow for several stations appeared to indicate that the theory was plausible.

Other types of mixed populations in peakflow data also were apparent, including partially regulated stations and low-permeability stations that were usually from the more arid parts of the state. Composite analyses were done for several of these stations; however, the thorough investigations required to justify and split the data, and actually do composite analyses for all of these other stations were beyond the scope of this study. Instead, peak-flow frequencies for partially regulated sites were computed using only station skews, and low-permeability stations were excluded from the regional analyses of peak-flow frequency.

Peak-flow frequency relations were developed for standard probabilities of 50, 20, 10, 4, 2, 1, 0.5 , and 0.2 percent or for frequencies of $2,5,10$, $25,50,100,200$, and 500 years, respectively. Streamflow-gaging stations with peak flows that are known to have been or that could have been affected to some degree by regulation (flood control, irrigation diversions, power generation, storage detention, or other factors) were excluded from regional peak-flow frequency analyses. Preliminary regional equations were developed and regions were defined using ordinary least squares (OLS) multiple-regression procedures. Final regression equations were developed using a GLS multiple-regression procedure. The GLS procedure adjusts for differences in record lengths, differ- 
ences in peak-flow variances, and cross-correlations of concurrent peak flows among stations used in the regression analysis.

For unregulated streams, eight sets of regression equations relating drainage-basin characteristics to peak flows for selected frequencies of occurrence were developed for seven regions of the state. Two sets of regional peak-flow frequency equations were developed for a high-permeability region that includes basins with $P 60$ greater than 4 inches per hour. Six sets of equations were developed for specific geographic areas, usually based on drainagebasin boundaries. Of the two sets of high-permeability equations, one set was developed using data from standard frequency analyses and the other was developed using data from composite frequency analyses. In general, these two sets of equations are for drainage basins with sandhills-type terrain. The six hydrologic regions based on geography were delineated using residual values and plots from preliminary regression analyses. There is overlap between several of the regions where more than one equation can be used to estimate peak flows.

Tables for each region include the equations, the SEE in $\log _{10}$ units and in percent, the average standard error of prediction (SEP) in $\log _{10}$ units, the average equivalent years of record for each equation, and the applicable range of the explanatory variables used to develop the equations. SEEs for the 100-year recurrence interval equations ranged from 12.1 to 63.8 percent.

For streamflow-gaging stations on regulated streams in Nebraska with at least 10 years of regulated peak flows, peak-flow frequency analyses were done using the LP3 distribution and the guidelines in Bulletin 17B of the Interagency Advisory Committee on Water Data. Skew coefficients used were those derived only from each station's peak-flow data. Peak-flow records within the period of the current regulated condition were used for the station analyses. For nine streams that included more than one station with at least 25 years of regulated record, graphs of peak-flow frequency and distance upstream of the mouth were estimated. Log-linear graphs were developed for the Niobrara, North Platte, South Platte, Platte, and Republican Rivers, and for Salt, Antelope, Frenchman, and Red Willow Creeks.

For the regional peak-flow frequency equations for unregulated streams, statistical analyses were done to estimate how additional years of peak-flow data might affect the ASEs of the equations for the 100 -year frequency of occurrence. For each regional equation, analyses were done for four different scenarios - 10 and 20 years of additional record from the stations used to develop the equation; and 10 and 20 years of additional record from new stations as well as from the stations used to develop the equation.

Various scenarios and regions can be compared to determine where the greatest overall benefits might be gained for the least amount of new data and hence for the least cost. For each scenario, plots of ASE and number of stations in the network were presented. Based on the results, data from new stations, rather than more data from stations used to develop the regional peak-flow frequency equations, probably would most reduce the ASE of the equations.

\section{SELECTED REFERENCES}

Beckman, E.W., 1976, Magnitude and frequency of floods in Nebraska: Water-Resources Investigations Report 76-109, 128 p.

Beckman, E.W., and Hutchison, N.E., 1962, Floods in Nebraska on small drainage areas, magnitude and frequency: Geological Survey Circular 458, $33 \mathrm{p}$.

Boohar, J.A., and Provaznik, M.K., 1996, Peak flows for the period of record for current and discontinued streamflow stations in Nebraska: U.S. Geological Survey Open-File Report 96-101, 518 p.

Boohar, J.A., Hoy, C.G., and Jelinek, F.J., 1995, Water resources data, Nebraska, water year 1994: U.S. Geological Survey Water-Data Report NE-94-1, 421 p.

Boohar, J.A., Hoy, C.G., and Steele, G.V., 1992, Water resources data, Nebraska, water year 1991: U.S. Geological Survey Water-Data Report NE-91-1, 354 p.

Cordes, K.E., 1993, Design discharges of culverts: Lincoln, Nebr., University of Nebraska, unpublished thesis, $106 \mathrm{p}$.

Dempster, G.R., Jr., 1983, WATSTORE User's Guide, instructions for streamflow/basin characteristics file-U.S. Geological Survey National Water Data Storage and Retrieval System (WATSTORE): U.S. Geological Survey, v. 4, chap. II, sec. A, 34 p. 
Dugan, J.T., 1984, Hydrologic characteristics of Nebraska soils: U.S. Geological Survey WaterSupply Paper 2222, 19 p. and 12 pls.

1986, Hydrologic characteristics of soils in parts of Arkansas, Colorado, Kansas, Missouri, Nebraska, New Mexico, Oklahoma, South Dakota, and Texas: U.S. Geological Survey Hydrologic Investigations Atlas HA-678, 1 sheet.

Dugan, J.T., Hobbs, R.D., and Ihm, L.A., 1990, Hydrologic characteristics of soils in the High Plains, northern Great Plains, and Central Texas Carbonates Regional Aquifer Systems: U.S. Geological Survey Hydrologic Investigations Atlas HA-714, 1 sheet.

Eash, D.A., 1994, A geographic information system procedure to quantify physical drainage-basin characteristics: Water Resources Bulletin, v. 30 , no. 1, p. $1-8$.

Environmental Systems Research Institute (ESRI), 1996, ARC/INFO user's guide, version 7.0.4: Redlands, Calif., Environmental Systems Research Institute.

Eschner, T.R., Hadley, R.F., and Crowley, K.D., 1983, Hydrologic and morphologic changes in channels of the Platte River Basin in Colorado, Wyoming, and Nebraska-a historical perspective: U.S. Geological Survey Professional Paper 1277-A, 39 p.

Flynn, K.M., Hummel, P.R., Lumb, A.M., and Kittle, J.L., Jr., 1995, User's manual for ANNIE, version 2, a computer program for interactive hydrologic data management: U.S. Geological Survey Water-Resources Investigations Report 95-4085, 211 p.

Furness, L.W., 1955, Floods in Nebraska, magnitude and frequency: Lincoln, Nebr., Nebraska Department of Roads and Irrigation, $103 \mathrm{p}$.

Gilroy, E.J., and Tasker, G.D., 1989, Multicollinearity and influential observations in hydrologic model selection, in Berk, Kenneth, and Malone, Linda, eds., Computing Science and Statistics-Proceedings of the $21 \mathrm{st}$ Symposium on the Interface: Alexandria, Va., American Statistical Association, p. 350-354.

Hardison, C.H., 1971, Prediction error of regression estimates of streamflow characteristics at ungaged sites: U.S. Geological Survey Professional Paper 750-C, p. C228-C236.
Harvey, C.A., and Eash, D.A., 1996, Description, instructions, and verification for Basinsoft, a computer program to quantify drainage-basin characteristics: U.S. Geological Survey WaterResources Investigations Report 95-4287, $25 \mathrm{p}$.

Hershfield, D.M., 1961, Rainfall frequency atlas of the United States: Washington, D.C., U.S. Department of Commerce, Weather Bureau Technical Paper No. 40, 115 p.

Interagency Advisory Committee on Water Data (IACWD), 1982, Guidelines for determining flood flow frequency: Hydrology Subcommittee Bulletin 17B, U.S. Department of the Interior, $28 \mathrm{p}$. and 14 appendices.

Kirby, W.H., 1981, Annual flood frequency analysis using U.S. Water Resources Council guidelines (program J407): U.S. Geological Survey Open-File Report 79-1336-I, WATSTORE User's Guide, v. 4, chap. I, sec. C, $56 \mathrm{p}$.

Majure, J.J., and Soenksen, P.J., 1991, Using a geographic information system to determine physical basin characteristics for use in floodfrequency equations, in Balthrop, B.H., and Terry, J.E., eds., U.S. Geological Survey National Computer Technology Meeting-Proceedings, Phoenix, Arizona, November 14-18, 1988: U.S. Geological Survey Water-Resources Investigations Report 90-4162, p. 31-40.

Matthai, H. F., 1968, Magnitude and frequency of floods in the United States, Part 6-B, Missouri River Basin below Sioux City, Iowa: U.S. Geological Survey Water-Supply Paper 1680, $471 \mathrm{p}$.

Natural Resources Conservation Service, 1994, State soil geographic (STATSGO) data base, data use information: U.S. Department of Agriculture, National Soil Survey Center, Miscellaneous Publication 1492, 110 p.

Patterson, J.L., 1966, Magnitude and frequency of floods in the United States, Part 6-A, Missouri River Basin above Sioux City, Iowa: U.S. Geological Survey Water-Supply Paper $1679,491 \mathrm{p}$.

Provaznik, M.K., 1997, Flood frequency for Nebraska using L-moments: Lincoln, Nebr., University of Nebraska, unpublished thesis, 58 p. and 16 appendices. 
Provaznik, M.K., and Hotchkiss, R.H., 1998, Analysis of gaging station flood-frequency estimates in Nebraska, using L-moment and region-of-influence methods: Washington, D.C., National Research Council, Transportation Research Board, Transportation Research Record no. 1647, p. 53-60.

Statware, Inc., 1990, Statit statistics reference manual release 2.3x: Corvallis, Oreg., Statware, Inc., chap. 6, 50 p., and chap 10, 42 p.

Tasker, G.D., 1978, Relation between standard errors in log units and standard errors in percent: U.S. Geological Survey, WRD Bulletin, JanMar-Apr-June 1978.

Tasker, G.D., and Stedinger, J.R., 1989, An operational GLS model for hydrologic regression: Amsterdam, Journal of Hydrology, Elsevier Science Publishers, v. 111, p. 361-375.

Ugland, R.C., Cochran, B.J., Hiner, M.M., and Steger, R.D., 1994, Water resources data, Colorado, water year 1993-volume 1-Missouri River Basin, Arkansas River Basin, and Rio Grande River Basin: U.S. Geological Survey Water-Data Report CO-93-1, 518 p.

U.S. Geological Survey, 1976, Hydrologic unit map1974-State of Nebraska: Reston, Va., U.S. Geological Survey, scale 1:500,000, 1 sheet.

U.S. Water Resources Council, 1976, Guidelines for determining flood flow frequency: Washington, D.C., Bulletin 17 of the Hydrology Committee, Water Resources Council. 
APPENDIX A-DESCRIPTIONS OF SELECTED DRAINAGE-BASINCHARACTERISTICS QUANTIFIED USING BASINSOFT, ARC-INFO, AND RELATED GIS PROGRAMS 


\section{Descriptions of Selected Drainage- Basin Characteristics Quantified Using Basinsoft, ARC-INFO, and Related GIS Programs}

\section{Morphometric Characteristics}

Morphometric characteristics were quantified using Basinsoft (modified from Harvey and Eash, 1996) and data layers representing the basin boundary (originally delineated on 1:24,000-scale maps for Nebraska stations and on 1:250,000-scale maps for stations outside of Nebraska), hydrography (stream network from 1:250,000-scale maps), hypsography (elevation contours created from 1:250,000scale digital elevation model), and lattice elevation model (created from 1:250,000-scale digital elevation model).

\section{Modifications to Basinsoft}

In Basinsoft, noncontributing drainage area $(N C D A)$ is intended to be delineated and measured like total drainage area $(T D A)$, and contributing drainage area $(C D A)$ is to be computed as $C D A=T D A-N C D A$. Because it was extremely difficult to delineate $N C D A$ in the large areas of sandhills, Basinsoft was modified to allow for manual input of $N C D A$ instead. Values of $N C D A$ were determined from published values of $N C D A$ or of $T D A$ and $C D A$. This modification did not affect $C D A$ computations, but did affect several other characteristics.

Basin slope ( $B S$ ), number of first-order streams (FOS), and total stream length $(T S L)$ are all intended to be measured only for the $C D A$ by excluding the delineated $N C D A(\mathrm{~s})$ from the measuring process. Because $N C D A(s)$ were not delineated, measurements for FOS and TSL were, therefore, made for the $T D A$. For $B S, T D A$ was substituted for $C D A$ in the internal computations and this characteristic, therefore, was representative of the $T D A$ and not just of the $C D A$. Slope ratio $(S R)$, computed from $B S$, also was affected by this modification.

However, because most stream segments from the 1:250,000-scale data were concentrated in the $C D A$, the values of $F O S$ and $T S L$ actually are fairly representative of the $C D A$ as well as the TDA. Therefore, characteristics that use $C D A$ and either FOS or TSL in their computations were not modified; these included drainage frequency $(D F)$, stream density $(S D)$, constant of channel maintenance $(C C M)$, and relative stream density $(R S D)$.

\section{Areal-Size Quantifications}

$\boldsymbol{T D A}$-Total drainage area, in square miles, includes all area within the drainage-basin boundary.

NCDA-Noncontributing drainage area, in square miles, includes all area within the drainage-basin boundary that does not contribute directly to surface runoff; from published value (or computed from published values of $T D A$ and $C D A$ ) manually input during Basinsoft computations.

$\boldsymbol{C D A}-$ Contributing drainage area, in square miles, includes all area within the drainage-basin boundary that contributes directly to surface runoff; computed as $C D A=T D A-N C D A$.

\section{Linear-Size Quantifications}

$\boldsymbol{B} \boldsymbol{L}-$ Basin length, in miles, measured along a line areally centered through the drainage-basin boundary data layer from basin outlet to the intersection of the main channel (extended) and the basin boundary.

$\boldsymbol{B P}-$ Basin perimeter, in miles, measured along entire drainage-basin boundary.

$\boldsymbol{B} \boldsymbol{W}$-Effective basin width, in miles, computed as $B W=C D A / B L$.

\section{Shape Quantifications}

$\boldsymbol{C R}-$ Compactness ratio, dimensionless, computed as $C R=B P / 2(\pi C D A)^{0.5}$.

$\boldsymbol{E} \boldsymbol{R}$-Elongation ratio, dimensionless, computed as $E R=\left[4 C D A / \pi(B L)^{2}\right]^{0.5}=1.13(1 / S F)^{0.5}$.

$\boldsymbol{R} \boldsymbol{B}$-Rotundity of basin, dimensionless, computed as $R B=\left[\pi(\mathrm{BL})^{2}\right] / 4 C D A=0.785 S F$.

$\boldsymbol{S F}$ - Shape factor, dimensionless, computed as $S F=B L / B W$.

\section{Relief Quantifications}

$\boldsymbol{B} \boldsymbol{R}-$ Basin relief, in feet, measured as the elevation difference in the lattice elevation model between the highest grid cell and the grid cell at the basin outlet.

$\boldsymbol{B} \boldsymbol{S}$-Average basin slope, in feet per mile, quantified using the "contour-band" method and computed as $B S=[$ (total length of all selected elevation contours within the $T D A$ )(contour interval)]/TDA.

$\boldsymbol{R} \boldsymbol{R}$-Relative relief, in feet per mile, computed as $R R=B R / B P$. 


\section{Aspect Quantification}

$\boldsymbol{B} \boldsymbol{A}-$ Basin azimuth, in degrees, measured as the compass direction (clockwise from north at 0 degrees) of a line from the intersection of the main channel (extended) and the basin boundary to the basin outlet.

\section{Stream-Network Quantifications}

FOS - Number of first-order streams, dimensionless, designated as the Strahler method within the TDA.

$\boldsymbol{B S O}$-Basin stream order, dimensionless, designated as the Strahler stream order of the main channel at the basin outlet.

$\boldsymbol{M C L}-$ Main-channel length, in miles, measured along the main channel from the basin outlet to the intersection of the main channel (extended) and the basin boundary.

$\boldsymbol{T S} \boldsymbol{L}$ - Total stream length, in miles, computed by summing the lengths of all stream segments within the TDA.

$\boldsymbol{D F}$ - Drainage frequency, in number of first-order streams per square mile, computed as $D F=F O S / C D A$. Although FOS was quantified for TDA, CDA was used in the computation of $D F$ because most stream segments are concentrated in the $C D A$-see "Modifications to Basinsoft".

MCSR - Main-channel sinuosity ratio, dimensionless, computed as $M C S R=M C L / B L$.

$\boldsymbol{S D}$-Stream density, in miles per square mile, computed as $S D=T S L / C D A$. Although $T S L$ was quantified for TDA, $C D A$ was used in the computation of $S D$ because most stream segments are concentrated in the $C D A$-see "Modifications to Basinsoft".

CCM - Constant of channel maintenance, in square miles per mile, computed as $C C M=C D A / T S L=1 / S D$. Although $T S L$ was quantified for TDA, CDA was used in the computation of $C C M$ because most stream segments are concentrated in the $C D A$-see "Modifications to Basinsoft."

$\boldsymbol{R S D}$-Relative stream density, dimensionless, computed as $R S D=(F O S)(C D A) /(T S L)^{2}=D F /(S D)^{2}$. Although $T S L$ was quantified for TDA, $C D A$ was used in the computation of $R S D$ because most stream segments are concentrated in the $C D A$-see "Modifications to Basinsoft".

\section{Relief-Stream Network Quantifications}

MCS-Main-channel slope index, in feet per mile, computed as $M C S=\left(E_{85}-E_{10}\right) /(0.75 M C L)$ where $E_{10}$ and $E_{85}$ are the respective elevations of points 10 and 85 percent of the distance along the main channel upstream from the basin outlet to the basin boundary.
MCSP -Main-channel slope proportion, dimensionless, computed as $M C S P=M C L /(M C S)^{0.5}$.

$\boldsymbol{R} \boldsymbol{N}$-Ruggedness number, in feet per mile, computed as $R N=(T S L)(B R) / C D A$

$\boldsymbol{S R}$-Slope ratio, dimensionless, computed as $S R=M C S / B S$.

\section{Soil Characteristics}

These were based on characteristics defined by Dugan (1984), quantified using ARC/INFO using equations A1 through A7 and data layers representing the basin boundary (originally delineated on 1:24,000-scale maps for Nebraska stations and on 1:250,000-scale maps for stations outside of Nebraska), and the State Soil Geographic Data Base (STATSGO) (Natural Resources Conservation Service, 1994).

P60 - Average permeability rate of 60-inch soil profile for drainage basin, in in/hr, computed from equations A1 through A3 next.

$$
P A v g H=(P M i n H+P M a x H) / 2
$$

where: $P A v g H=$ average permeability rate of soil horizon, in in $/ \mathrm{hr}$,

$P M i n H=$ minimum value for range in permeability of soil horizon, in in $/ \mathrm{hr}$, and

$P M a x H=$ maximum value for range in permeability of soil horizon, in in $/ \mathrm{hr}$.

$$
\text { P60_SS }=(\Sigma(H T \times P A v g H)) / 60
$$

where: P60_SS $=$ average permeability rate of 60-inch soil profile for soil series, in in $/ \mathrm{hr}$, (fig. A3) and

$H T=$ thickness of soil horizon, in inches.

$$
P 60=\Sigma\left(P 60 \_S S \times F A\right)
$$

where: $P 60=$ average permeability rate of 60 -inch soil profile for drainage basin, in in $/ \mathrm{hr}$, and

$F A=$ fractional area of drainage basin occupied by soil series. 
$A W C$-Average available water capacity of the 60 -inch soil profile for the drainage basin, in in/hr, computed using equations $\mathrm{A} 4$ and $\mathrm{A} 5$ next.

$$
\begin{aligned}
A W C \_S S & =(\Sigma(H T \times A W C H)) / 60 \\
A W C & =\Sigma\left(A W C \_S S \times F A\right)
\end{aligned}
$$

$\boldsymbol{P L P}$-Average of minimum permeabilities of the least permeable layers for drainage basin, in in/hr, computed using equation A6 next.

$$
P L P=\Sigma\left(P L P \_S S \times F A\right)
$$

where: $P L P_{-} S S=$ minimum permeability of the least permeable layer for soil series, in in/hr.

MSS - Average maximum soil slope for drainage basin, in percent, computed using equation A7 next.

$$
M S S=\Sigma\left(M S S \_S S \times F A\right)
$$

where: $M S S=$ average maximum soil slope for drainage basin, in percent, and

MSS_SS = maximum soil slope for soil series, in percent.

\section{Precipitation Characteristics}

These were quantified using ARC/INFO and data layers representing the basin boundary (originally delineated on 1:24,000-scale maps for Nebraska stations and on 1:250,000-scale maps for stations outside of Nebraska), the 2-year (recurrence interval), 24-hour (duration) precipitation contours (from Weather Bureau Technical Paper 40 (Hershfield, 1961)), and Theissen polygons of mean annual precipitation for the period 1961-90 (from the National Climatic Data Center Web site).

$\boldsymbol{T T P}$ - Two-year (recurrence interval), 24-hour (duration) precipitation, in inches, computed as the area-weighted average of precipitation polygons within the TDA (fig. A1).

$\boldsymbol{M A P}-$ Mean annual precipitation, in inches, computed as the area-weighted average of precipitation polygons within the $T D A$ (fig. A2).

\section{A-4 Peak-Flow Frequency Relations and Evaluation of the Peak-Flow Gaging Network in Nebraska}



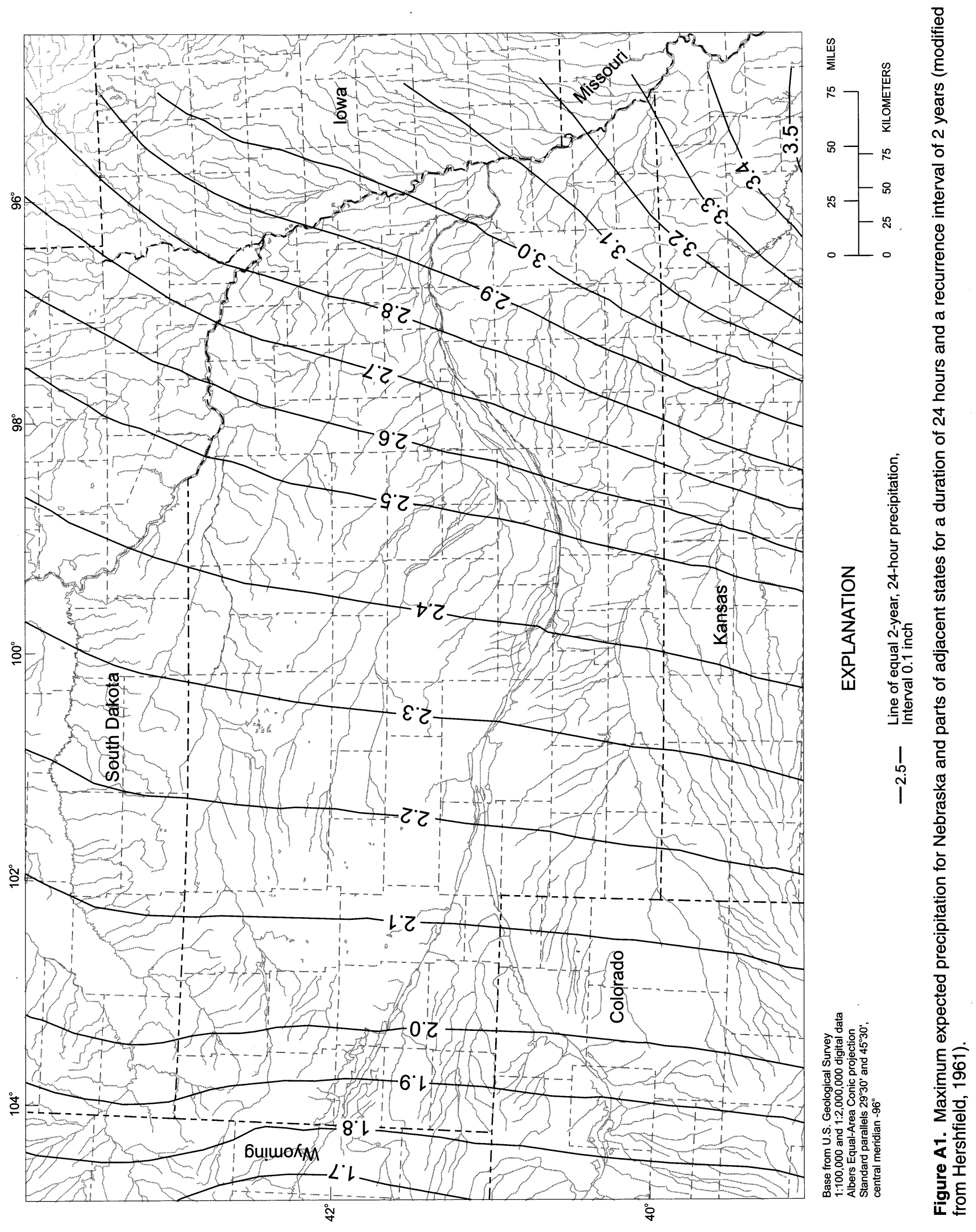


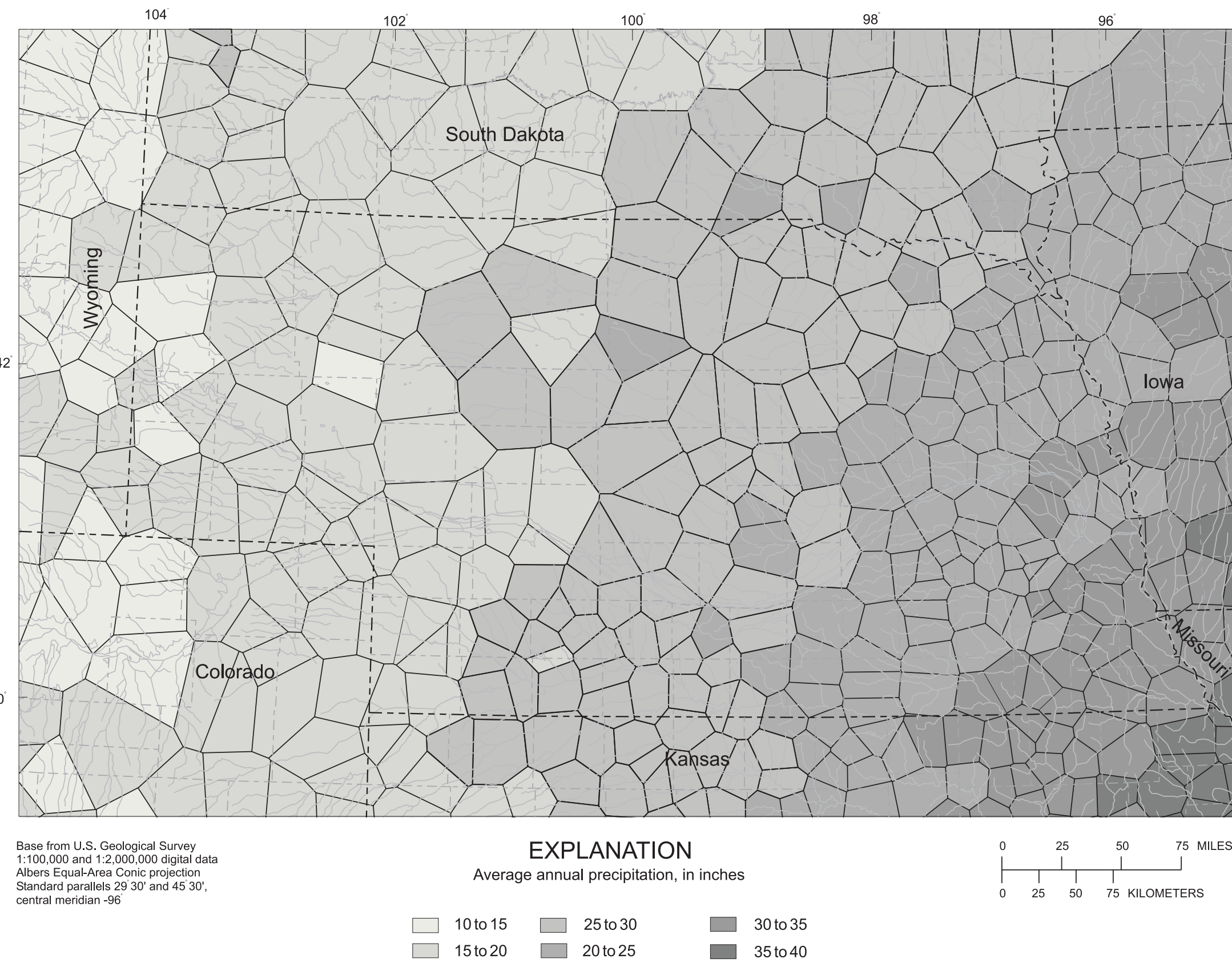

Figure A2. Thiessen polygons of mean annual precipitation for National Oceanic and Atmospheric Administration and National Weather Service rain gages in Nebraska and parts of adjacent states for the period 1961-90. 


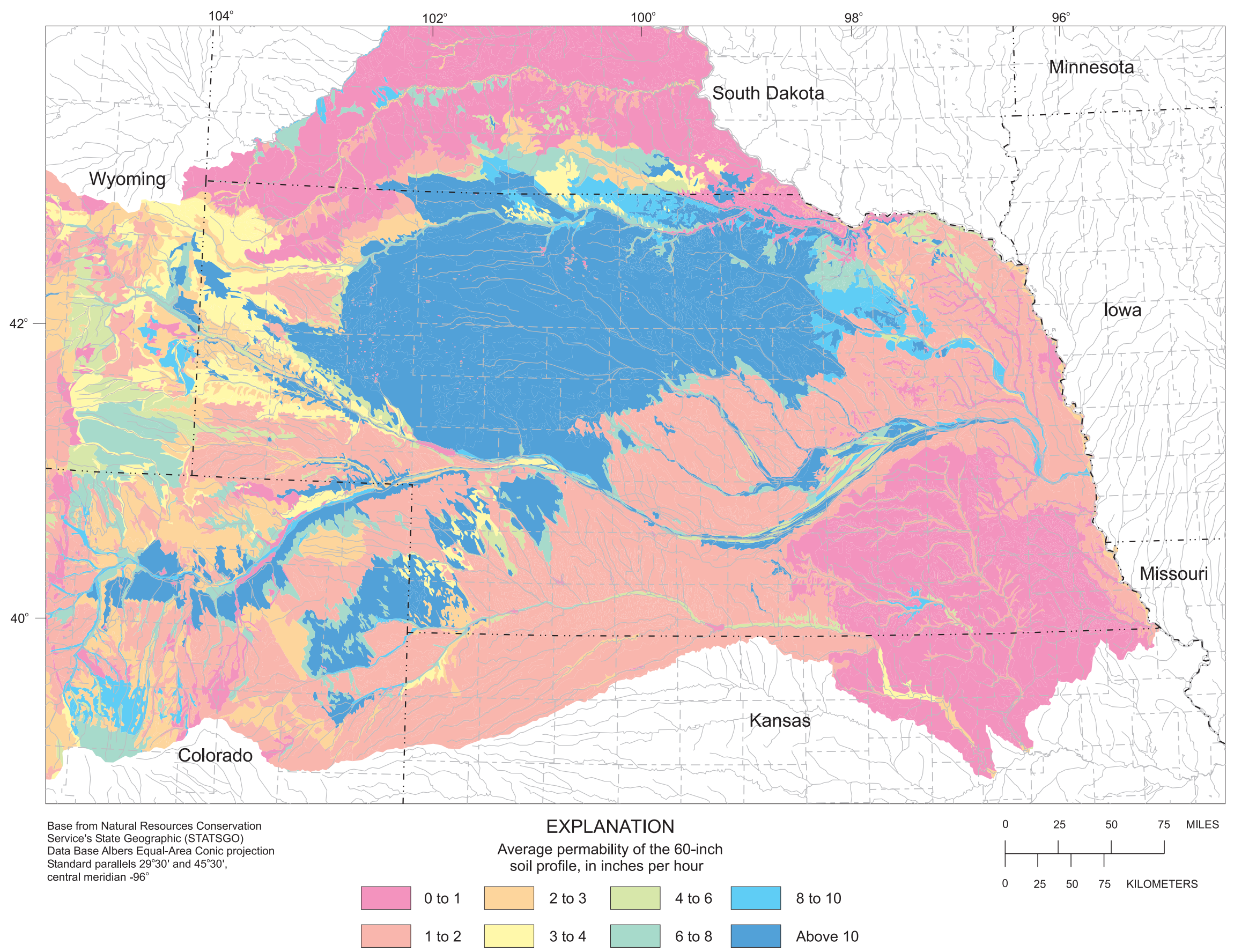

Figure A3. Average permeability of the 60 -inch soil profile for nebraska and parts of adjacent states. 
APPENDIX B-TABLES OF DRAINAGE-BASIN CHARACTERISTICS AND PEAK-FLOW FREQUENCY DATA 
Table B1. Selected drainage-basin characteristics for streamflow-gaging stations in Nebraska and for selected out-of-state stations

Drainage-basin characteristics (quantified from 1:250,000-scale data using geographic-information-system procedures, except as noted; see appendix A for descriptions); $A W C$, available water capacity of the 60-inch soil profile, in inches per inch; $B S$, basin slope, in feet per mile; $C D A$, contributing drainage area, in square miles, derived from published data; $C R$, compactness ratio, dimensionless;

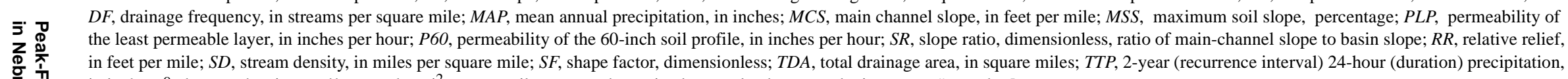
in inches; ${ }^{\circ}$, degrees; ', minutes; ', seconds; $\mathrm{mi}^{2}$, square miles; --, not determined; _, value known to be incorrect; \#, number]

\begin{tabular}{|c|c|c|c|c|c|c|c|c|c|c|c|c|c|}
\hline \multirow[b]{2}{*}{$\begin{array}{c}\text { Map } \\
\text { num- } \\
\text { ber }\end{array}$} & \multirow[b]{2}{*}{$\begin{array}{l}\text { Station } \\
\text { number }\end{array}$} & \multirow[b]{2}{*}{ Station name-remarks } & \multirow[b]{2}{*}{$\begin{array}{c}\text { Latitude } \\
\left({ }^{0}, "\right)\end{array}$} & \multirow[b]{2}{*}{$\begin{array}{c}\text { Longitude } \\
\left({ }^{(},{ }^{\prime \prime}\right)\end{array}$} & \multirow{2}{*}{$\begin{array}{c}\text { Published } \\
\text { total } \\
\text { drainage } \\
\text { area } \\
\left(\mathrm{mi}^{2}\right)\end{array}$} & \multicolumn{8}{|c|}{ Drainage-basin characteristics } \\
\hline & & & & & & $\begin{array}{l}\text { TDA } \\
\text { CDA }\end{array}$ & $\begin{array}{l}\text { SF } \\
\text { RR }\end{array}$ & $\begin{array}{c}\text { BS } \\
\text { MCS }\end{array}$ & $\begin{array}{l}\text { CR } \\
\text { SD }\end{array}$ & $\begin{array}{l}\text { TTP } \\
\text { MAP }\end{array}$ & $\begin{array}{l}\text { AWC } \\
\text { PLP }\end{array}$ & $\begin{array}{l}\text { DF } \\
\text { SR }\end{array}$ & $\begin{array}{l}\text { MSS } \\
\text { P60 }\end{array}$ \\
\hline 3822 & 06382200 & Pritchard Draw near Lance Creek, Wyoming & 431200 & 1044059 & 5.10 & $\begin{array}{l}5.42 \\
5.42\end{array}$ & $\begin{array}{l}1.64 \\
41.6\end{array}$ & $\begin{array}{l}126 \\
101\end{array}$ & $\begin{array}{l}1.17 \\
1.00\end{array}$ & $\begin{array}{r}1.75 \\
14.91\end{array}$ & $\begin{array}{l}0.07 \\
0.10\end{array}$ & $\begin{array}{l}0.369 \\
0.804\end{array}$ & $\begin{array}{c}27.4 \\
0.93\end{array}$ \\
\hline 3962 & 06396200 & Fiddle Creek near Edgemont, South Dakota & 431815 & 1035945 & 0.64 & $\begin{array}{l}0.61 \\
0.61\end{array}$ & $\begin{array}{l}1.14 \\
17.3\end{array}$ & $\begin{array}{l}73.8 \\
75.3\end{array}$ & $\begin{array}{l}1.50 \\
1.78\end{array}$ & $\begin{array}{r}1.85 \\
14.19\end{array}$ & $\begin{array}{l}0.08 \\
0.11\end{array}$ & $\begin{array}{l}1.64 \\
0.709\end{array}$ & $\begin{array}{c}17.7 \\
0.63\end{array}$ \\
\hline 3963 & 06396300 & Cottonwood Creek tributary near Edgemont, South Dakota & 431748 & 1035201 & 0.09 & $\begin{array}{l}0.18 \\
0.18\end{array}$ & $\begin{array}{l}1.10 \\
54.5\end{array}$ & $\begin{array}{r}171 \\
--\end{array}$ & $\begin{array}{l}1.07 \\
--\end{array}$ & $\begin{array}{r}1.95 \\
15.68\end{array}$ & $\begin{array}{l}0.08 \\
0.11\end{array}$ & $\begin{array}{l}5.47 \\
--\end{array}$ & $\begin{array}{c}17.7 \\
0.63\end{array}$ \\
\hline 3964a & 06396490 & Warbonnet Creek near Harrison, Nebraska & $42 \quad 5043$ & 1035441 & 24.5 & $\begin{array}{l}24.4 \\
24.4\end{array}$ & $\begin{array}{l}1.38 \\
13.3\end{array}$ & $\begin{array}{r}343 \\
--\end{array}$ & $\begin{array}{l}1.33 \\
0.596\end{array}$ & $\begin{array}{r}1.85 \\
16.84\end{array}$ & $\begin{array}{l}0.12 \\
0.61\end{array}$ & $\begin{array}{l}0.492 \\
--\end{array}$ & $\begin{array}{c}15.7 \\
2.23\end{array}$ \\
\hline 3997 & 06399700 & Pine Creek near Ardmore, South Dakota & $43 \quad 1113$ & 1033823 & 5.47 & $\begin{array}{l}5.28 \\
5.28\end{array}$ & 41.54 & $\begin{array}{l}106 \\
87.1\end{array}$ & $\begin{array}{l}1.17 \\
0.880\end{array}$ & $\begin{array}{r}1.95 \\
15.90\end{array}$ & $\begin{array}{l}0.08 \\
0.11\end{array}$ & $\begin{array}{l}0.379 \\
0.819\end{array}$ & $\begin{array}{c}17.7 \\
0.63\end{array}$ \\
\hline 4000 & 06400000 & Hat Creek near Edgemont, South Dakota & 431424 & 1033516 & 1,044 & $\begin{array}{l}967 \\
967\end{array}$ & $\begin{array}{l}2.01 \\
6.38\end{array}$ & $\begin{array}{c}167 \\
9.5\end{array}$ & $\begin{array}{l}1.73 \\
0.560\end{array}$ & $\begin{array}{r}1.90 \\
15.99\end{array}$ & $\begin{array}{l}0.08 \\
0.30\end{array}$ & $\begin{array}{l}0.288 \\
0.068\end{array}$ & $\begin{array}{c}20.2 \\
1.00\end{array}$ \\
\hline 4008a & 06400875 & Horsehead Creek at Oelrichs, South Dakota & 431117 & 1031334 & 187 & $\begin{array}{l}186 \\
186\end{array}$ & $\begin{array}{l}2.50 \\
9.58\end{array}$ & $\begin{array}{l}56.3 \\
11.2\end{array}$ & $\begin{array}{l}1.47 \\
1.19\end{array}$ & $\begin{array}{r}2.01 \\
16.55\end{array}$ & $\begin{array}{l}0.07 \\
0.09\end{array}$ & $-\overline{-}$ & $\begin{array}{c}20.2 \\
0.30\end{array}$ \\
\hline 4432 & 06443200 & White River tributary near Glen, Nebraska & 423711 & 1033909 & 7.97 & $\begin{array}{l}7.59 \\
7.59\end{array}$ & $\begin{array}{l}1.80 \\
38.7\end{array}$ & $\begin{array}{l}360 \\
98.2\end{array}$ & $\begin{array}{l}1.34 \\
0.534\end{array}$ & $\begin{array}{r}1.95 \\
16.84\end{array}$ & $\begin{array}{l}0.09 \\
1.08\end{array}$ & $\begin{array}{l}0.132 \\
0.273\end{array}$ & $\begin{array}{c}24.5 \\
3.58\end{array}$ \\
\hline 4433 & 06443300 & Deep Creek near Glen, Nebraska & 423636 & 1033321 & 10.87 & $\begin{array}{l}10.6 \\
10.6\end{array}$ & $\begin{array}{l}3.06 \\
48.3\end{array}$ & $\begin{array}{l}462 \\
117\end{array}$ & $\begin{array}{l}1.45 \\
0.543\end{array}$ & $\begin{array}{r}1.95 \\
14.21\end{array}$ & $\begin{array}{l}0.08 \\
0.95\end{array}$ & $\begin{array}{l}0.189 \\
0.252\end{array}$ & $\begin{array}{c}27.9 \\
3.40\end{array}$ \\
\hline 4437 & 06443700 & Soldiers Creek near Crawford, Nebraska & $4241 \quad 18$ & 1033208 & 52.6 & $\begin{array}{l}49.3 \\
49.3\end{array}$ & 23.5 & $\begin{array}{l}329 \\
66.5\end{array}$ & $\begin{array}{l}1.53 \\
0.539\end{array}$ & $\begin{array}{r}1.95 \\
16.84\end{array}$ & $\begin{array}{l}0.09 \\
1.07\end{array}$ & $\begin{array}{l}0.101 \\
0.202\end{array}$ & $\begin{array}{c}24.5 \\
3.58\end{array}$ \\
\hline 4440 & 06444000 & White River at Crawford, Nebraska & $42 \quad 4132$ & 1032503 & 313 & $\begin{array}{l}256 \\
256\end{array}$ & $\begin{array}{r}2.05 \\
14.1\end{array}$ & $\begin{array}{l}335 \\
43.5\end{array}$ & $\begin{array}{l}1.51 \\
0.730\end{array}$ & $\begin{array}{r}1.93 \\
15.97\end{array}$ & $\begin{array}{l}0.10 \\
1.04\end{array}$ & $\begin{array}{l}0.137 \\
0.130\end{array}$ & $\begin{array}{c}23.6 \\
3.44\end{array}$ \\
\hline 4450 & 06445000 & $\begin{array}{l}\text { White River below Cottonwood Creek near Whitney, } \\
\text { Nebraska }\end{array}$ & 424835 & $103 \quad 1005$ & 676 & $\begin{array}{l}635 \\
635\end{array}$ & $\begin{array}{c}2.24 \\
11.4\end{array}$ & $\begin{array}{l}294 \\
29.5\end{array}$ & $\begin{array}{l}1.56 \\
0.816\end{array}$ & $\begin{array}{r}1.96 \\
15.82\end{array}$ & $\begin{array}{l}0.10 \\
0.66\end{array}$ & $\begin{array}{l}0.140 \\
0.100\end{array}$ & $\begin{array}{c}21.6 \\
2.13\end{array}$ \\
\hline 4455 & 06445500 & White River near Chadron, Nebraska & 424959 & $103 \quad 0700$ & 750 & $\begin{array}{l}709 \\
709\end{array}$ & $\begin{array}{c}2.52 \\
10.8\end{array}$ & $\begin{array}{c}293 \\
28.2\end{array}$ & $\begin{array}{l}1.58 \\
0.820\end{array}$ & $\begin{array}{r}1.97 \\
15.78\end{array}$ & $\begin{array}{l}0.07 \\
0.63\end{array}$ & $\begin{array}{l}0.141 \\
0.096\end{array}$ & $\begin{array}{c}21.5 \\
2.02\end{array}$ \\
\hline $4455 \mathrm{a}$ & 06445530 & $\begin{array}{l}\text { Chadron Creek tributary at Chadron State Park near } \\
\text { Chadron, Nebraska }\end{array}$ & 424149 & 1030009 & 2.59 & $\begin{array}{l}2.75 \\
2.75\end{array}$ & $\begin{array}{l}5.18 \\
40.5\end{array}$ & $\begin{array}{c}212 \\
86.7\end{array}$ & $\begin{array}{l}1.56 \\
1.43\end{array}$ & $\begin{array}{r}2.05 \\
15.43\end{array}$ & $\begin{array}{l}0.10 \\
0.31\end{array}$ & $\begin{array}{l}0.363 \\
0.311\end{array}$ & $\begin{array}{c}46.3 \\
0.83\end{array}$ \\
\hline $4455 b$ & 06445560 & $\begin{array}{l}\text { Chadron Creek at Chadron State Park near Chadron, } \\
\text { Nebraska }\end{array}$ & $4242 \quad 27$ & 1030033 & 15.4 & $\begin{array}{l}14.3 \\
14.3\end{array}$ & $\begin{array}{l}1.58 \\
29.2\end{array}$ & $\begin{array}{c}239 \\
83.0\end{array}$ & $\begin{array}{l}1.28 \\
0.982\end{array}$ & $\begin{array}{r}2.05 \\
15.43\end{array}$ & $\begin{array}{l}0.10 \\
0.31\end{array}$ & $\begin{array}{l}0.280 \\
0.348\end{array}$ & $\begin{array}{c}46.2 \\
0.83\end{array}$ \\
\hline $4455 \mathrm{c}$ & 06445590 & Big Bordeaux Creek near Chadron, Nebraska & $4243 \quad 30$ & 1025544 & 9.42 & $\begin{array}{l}9.01 \\
9.01\end{array}$ & 30.3 & $\begin{array}{l}306 \\
63.7\end{array}$ & $\begin{array}{l}1.32 \\
1.06\end{array}$ & $\begin{array}{r}2.05 \\
15.43\end{array}$ & $\begin{array}{l}0.10 \\
0.31\end{array}$ & $\begin{array}{l}0.333 \\
1.17\end{array}$ & $\begin{array}{c}46.3 \\
0.83\end{array}$ \\
\hline 4460 & 06446000 & White River near Oglala, South Dakota & $43 \quad 1517$ & 1024928 & 2,200 & $\begin{array}{l}2,160 \\
2,160\end{array}$ & $\begin{array}{l}3.48 \\
6.98\end{array}$ & $\begin{array}{c}240 \\
12.2\end{array}$ & $\begin{array}{l}1.68 \\
0.82\end{array}$ & $\begin{array}{r}2.02 \\
16.35\end{array}$ & $\begin{array}{l}0.10 \\
0.39\end{array}$ & $\begin{array}{l}0.178 \\
0.051\end{array}$ & $\begin{array}{c}24.2 \\
1.19\end{array}$ \\
\hline
\end{tabular}


Table B1. Selected drainage-basin characteristics for streamflow-gaging stations in Nebraska and for selected out-of-state stations--Continued

\begin{tabular}{|c|c|c|c|c|c|c|c|c|c|c|c|c|c|}
\hline \multirow[b]{2}{*}{$\begin{array}{c}\text { Map } \\
\text { num- } \\
\text { ber }\end{array}$} & \multirow[b]{2}{*}{$\begin{array}{c}\text { Station } \\
\text { number }\end{array}$} & \multirow[b]{2}{*}{ Station name-remarks } & \multirow[b]{2}{*}{$\begin{array}{c}\text { Latitude } \\
\left({ }^{0}, \%\right)\end{array}$} & \multirow[b]{2}{*}{$\begin{array}{c}\text { Longitude } \\
\left(0,{ }^{\circ},{ }^{\prime}\right)\end{array}$} & \multirow{2}{*}{$\begin{array}{c}\text { Published } \\
\text { total } \\
\text { drainage } \\
\text { area } \\
\left(\mathrm{mi}^{2}\right)\end{array}$} & \multicolumn{8}{|c|}{ Drainage-basin characteristics } \\
\hline & & & & & & $\begin{array}{l}\text { TDA } \\
\text { CDA }\end{array}$ & $\begin{array}{l}\text { SF } \\
\text { RR }\end{array}$ & $\begin{array}{c}\text { BS } \\
\text { MCS }\end{array}$ & $\begin{array}{l}\text { CR } \\
\text { SD }\end{array}$ & $\begin{array}{l}\text { TTP } \\
\text { MAP }\end{array}$ & $\begin{array}{l}\text { AWC } \\
\text { PLP }\end{array}$ & $\begin{array}{l}\text { DF } \\
\text { SR }\end{array}$ & $\begin{array}{l}\text { MSS } \\
\text { P60 }\end{array}$ \\
\hline 4464 & 06446400 & Cain Creek tributary at Imlay, South Dakota & 434259 & 1022322 & 15.8 & $\begin{array}{l}16.5 \\
16.5\end{array}$ & $\begin{array}{c}3.65 \\
21.7\end{array}$ & $\begin{array}{l}53.5 \\
17.9\end{array}$ & $\begin{array}{l}1.28 \\
0.740\end{array}$ & $\begin{array}{r}2.05 \\
15.86\end{array}$ & $\begin{array}{l}0.08 \\
0.78\end{array}$ & $\begin{array}{l}0.303 \\
0.336\end{array}$ & $\begin{array}{c}28.3 \\
2.01\end{array}$ \\
\hline 4475 & 06447500 & Little White River near Martin, South Dakota & $43 \quad 1000$ & 1013746 & 310 & $\begin{array}{l}265 \\
230\end{array}$ & $\begin{array}{l}4.83 \\
6.02\end{array}$ & $\begin{array}{r}55.7 \\
5.6\end{array}$ & $\begin{array}{l}1.78 \\
0.677\end{array}$ & $\begin{array}{r}2.15 \\
17.08\end{array}$ & $\begin{array}{l}0.12 \\
1.72\end{array}$ & $\begin{array}{l}0.148 \\
0.100\end{array}$ & $\begin{array}{c}13.6 \\
4.27\end{array}$ \\
\hline 4480 & 06448000 & Lake Creek above refuge near Tuthill, South Dakota & 430507 & 1013603 & 58 & $\begin{array}{l}58 \\
23\end{array}$ & -- & -- & $\begin{array}{l}-- \\
--\end{array}$ & $\begin{array}{r}2.15 \\
17.17\end{array}$ & $\begin{array}{l}0.10 \\
3.87\end{array}$ & $\begin{array}{l}-- \\
--\end{array}$ & $\begin{array}{c}23.3 \\
8.79\end{array}$ \\
\hline 4491 & 06449100 & Little White River near Vetal, South Dakota & 430602 & $101 \quad 1349$ & 590 & $\begin{array}{l}556 \\
415\end{array}$ & $\begin{array}{l}6.13 \\
6.01\end{array}$ & $\begin{array}{r}55.7 \\
8.0\end{array}$ & $\begin{array}{l}2.03 \\
0.688\end{array}$ & $\begin{array}{r}2.15 \\
17.59\end{array}$ & $\begin{array}{l}0.10 \\
2.72\end{array}$ & $\begin{array}{l}0.159 \\
0.144\end{array}$ & $\begin{array}{c}16.8 \\
6.53\end{array}$ \\
\hline 4492a & 06449250 & Spring Creek near St. Francis, South Dakota & 430421 & 1010149 & 57 & $\begin{array}{l}94.8 \\
94.8\end{array}$ & $\begin{array}{l}4.59 \\
6.82\end{array}$ & $\begin{array}{l}86.4 \\
11.6\end{array}$ & $\begin{array}{l}2.23 \\
0.297\end{array}$ & $\begin{array}{r}2.22 \\
18.56\end{array}$ & $\begin{array}{l}0.08 \\
5.21\end{array}$ & $\begin{array}{l}0.032 \\
0.134\end{array}$ & $\begin{array}{l}21.5 \\
12.20\end{array}$ \\
\hline 4495 & 06449500 & Little White River near Rosebud, South Dakota & 431931 & 1005259 & 1,020 & $\begin{array}{l}999 \\
760\end{array}$ & $\begin{array}{l}7.99 \\
5.79\end{array}$ & $\begin{array}{l}114 \\
9.0\end{array}$ & $\begin{array}{l}2.41 \\
0.642\end{array}$ & $\begin{array}{r}2.19 \\
18.09\end{array}$ & $\begin{array}{l}0.10 \\
3.01\end{array}$ & $\begin{array}{l}0.130 \\
0.079\end{array}$ & $\begin{array}{l}18.0 \\
7.57\end{array}$ \\
\hline 4497 & 06449700 & Little Oak Creek near Mission, South Dakota & 431944 & 1004233 & 2.58 & $\begin{array}{l}2.42 \\
2.42\end{array}$ & $\begin{array}{r}0.66 \\
13.26\end{array}$ & $\begin{array}{r}54.3 \\
\underline{0.0} \\
\end{array}$ & $\begin{array}{l}1.12 \\
0.596\end{array}$ & $\begin{array}{r}2.25 \\
19.32\end{array}$ & $\begin{array}{l}0.10 \\
0.44\end{array}$ & $\begin{array}{l}0.414 \\
\underline{0.000}\end{array}$ & $\begin{array}{l}9.1 \\
2.67\end{array}$ \\
\hline 4497b & 06449750 & West Branch Horse Creek near Mission, South Dakota & 432335 & 1004232 & 6.31 & $\begin{array}{l}6.51 \\
6.51\end{array}$ & $\begin{array}{l}1.67 \\
19.2\end{array}$ & $\begin{array}{l}92.9 \\
59.8\end{array}$ & $\begin{array}{l}1.19 \\
1.10\end{array}$ & $\begin{array}{r}2.25 \\
18.96\end{array}$ & $\begin{array}{l}0.06 \\
0.14\end{array}$ & $\begin{array}{l}0.307 \\
0.644\end{array}$ & $\begin{array}{c}24.7 \\
0.63\end{array}$ \\
\hline 4505 & 06450500 & Little White River below White River, South Dakota & 433605 & 1004457 & 1,570 & $\begin{array}{l}1,520 \\
1,310\end{array}$ & $\begin{array}{l}6.66 \\
5.83\end{array}$ & $\begin{array}{c}141 \\
10.8\end{array}$ & $\begin{array}{l}2.31 \\
0.759\end{array}$ & $\begin{array}{r}2.21 \\
18.21\end{array}$ & $\begin{array}{l}0.09 \\
2.18\end{array}$ & $\begin{array}{l}0.200 \\
0.077\end{array}$ & $\begin{array}{c}18.8 \\
5.79\end{array}$ \\
\hline 4535 & 06453500 & Ponca Creek at Anoka, Nebraska & 425625 & 985030 & 505 & $\begin{array}{l}504 \\
504\end{array}$ & $\begin{array}{l}5.71 \\
5.21\end{array}$ & $\begin{array}{c}116 \\
8.7\end{array}$ & $\begin{array}{l}1.96 \\
0.608\end{array}$ & $\begin{array}{r}2.39 \\
24.69\end{array}$ & $\begin{array}{l}0.12 \\
0.70\end{array}$ & $\begin{array}{l}0.099 \\
0.075\end{array}$ & $\begin{array}{l}9.5 \\
3.89\end{array}$ \\
\hline 4536 & 06453600 & Ponca Creek at Verdel, Nebraska & 424839 & $98 \quad 1034$ & 812 & $\begin{array}{l}812 \\
812\end{array}$ & $\begin{array}{l}9.91 \\
4.80\end{array}$ & $\begin{array}{c}152 \\
8.8\end{array}$ & $\begin{array}{l}2.49 \\
0.624\end{array}$ & $\begin{array}{r}2.41 \\
23.96\end{array}$ & $\begin{array}{l}0.12 \\
0.81\end{array}$ & $\begin{array}{l}0.098 \\
0.058\end{array}$ & $\begin{array}{c}11.6 \\
3.42\end{array}$ \\
\hline 4562 & 06456200 & Pebble Creek near Esther, Nebraska & 423538 & 1030355 & 3.07 & $\begin{array}{l}3.74 \\
3.74\end{array}$ & $\begin{array}{c}3.38 \\
19.0\end{array}$ & $\begin{array}{l}52.5 \\
35.2\end{array}$ & $\begin{array}{l}1.61 \\
0.995\end{array}$ & $\begin{array}{r}2.05 \\
15.43\end{array}$ & $\begin{array}{l}0.14 \\
0.36\end{array}$ & $\begin{array}{l}0.534 \\
0.672\end{array}$ & $\begin{array}{c}13.9 \\
1.08\end{array}$ \\
\hline 4563 & 06456300 & Pebble Creek near Dunlap, Nebraska & 422947 & 1025835 & 23.5 & $\begin{array}{l}24.1 \\
24.1\end{array}$ & $\begin{array}{c}5.96 \\
16.7\end{array}$ & $\begin{array}{l}113 \\
37.2\end{array}$ & $\begin{array}{l}1.78 \\
1.16\end{array}$ & $\begin{array}{r}2.05 \\
16.66\end{array}$ & $\begin{array}{l}0.12 \\
0.37\end{array}$ & $\begin{array}{l}0.291 \\
0.331\end{array}$ & $\begin{array}{c}16.9 \\
1.13\end{array}$ \\
\hline 4564 & 06456400 & Cottonwood Creek near Dunlap, Nebraska & 422929 & 1025808 & 82.2 & $\begin{array}{l}82.2 \\
82.2\end{array}$ & $\begin{array}{c}2.93 \\
11.9\end{array}$ & $\begin{array}{l}117 \\
28.8\end{array}$ & $\begin{array}{l}1.35 \\
0.989\end{array}$ & $\begin{array}{r}2.05 \\
16.90\end{array}$ & $\begin{array}{l}0.11 \\
0.44\end{array}$ & $\begin{array}{l}0.195 \\
0.246\end{array}$ & $\begin{array}{c}20.2 \\
1.36\end{array}$ \\
\hline 4572 & 06457200 & Berea Creek near Alliance, Nebraska & 420823 & 1025131 & 32.3 & $\begin{array}{l}31.3 \\
31.3\end{array}$ & $\begin{array}{l}14.7 \\
7.58\end{array}$ & $\begin{array}{l}49.2 \\
17.0\end{array}$ & $\begin{array}{l}2.03 \\
1.37\end{array}$ & $\begin{array}{r}2.05 \\
16.83\end{array}$ & $\begin{array}{l}0.16 \\
0.39\end{array}$ & $\begin{array}{l}0.383 \\
0.346\end{array}$ & $\begin{array}{l}3.0 \\
1.17\end{array}$ \\
\hline 4578 & 06457800 & Antelope Creek tributary near Gordon, Nebraska & 424957 & 1021209 & 26.6 & $\begin{array}{l}25.1 \\
25.1\end{array}$ & $\begin{array}{c}4.76 \\
11.9\end{array}$ & $\begin{array}{r}124.8 \\
34.2\end{array}$ & $\begin{array}{l}1.54 \\
1.10\end{array}$ & $\begin{array}{r}2.13 \\
18.55\end{array}$ & $\begin{array}{l}0.14 \\
0.37\end{array}$ & $\begin{array}{l}0.239 \\
0.274\end{array}$ & $\begin{array}{c}10.5 \\
1.10\end{array}$ \\
\hline 4591a & 06459175 & Snake River at Doughboy, Nebraska & 423651 & $101 \quad 1638$ & 405 & $\begin{array}{l}391 \\
26.0\end{array}$ & $\begin{array}{c}80.0 \\
5.70\end{array}$ & $\begin{array}{c}240 \\
14.6\end{array}$ & $\begin{array}{c}10.6 \\
3.17\end{array}$ & $\begin{array}{r}2.15 \\
18.37\end{array}$ & $\begin{array}{l}0.08 \\
5.62\end{array}$ & $\begin{array}{l}0.231 \\
1.13\end{array}$ & $\begin{array}{l}26.5 \\
12.76\end{array}$ \\
\hline 4592 & 06459200 & Snake River above Merritt Reservoir, Nebraska & 423539 & $10102 \quad 20$ & 440 & $\begin{array}{l}426 \\
28.0\end{array}$ & $\begin{array}{l}120 \\
5.24\end{array}$ & $\begin{array}{l}249 \\
11.9\end{array}$ & $\begin{array}{c}12.2 \\
3.48\end{array}$ & $\begin{array}{r}2.16 \\
18.65\end{array}$ & $\begin{array}{l}0.08 \\
5.63\end{array}$ & $\begin{array}{l}0.179 \\
0.048\end{array}$ & $\begin{array}{l}26.6 \\
12.76\end{array}$ \\
\hline 4609 & 06460900 & Minnechaduza Creek near Kilgore, Nebraska & 425910 & 1005355 & 85 & $\begin{array}{l}76.5 \\
76.5\end{array}$ & $\begin{array}{l}1.46 \\
8.12\end{array}$ & $\begin{array}{c}103 \\
11.9\end{array}$ & $\begin{array}{l}2.07 \\
0.193\end{array}$ & $\begin{array}{r}2.25 \\
18.65\end{array}$ & $\begin{array}{l}0.08 \\
4.48\end{array}$ & $\begin{array}{l}0.026 \\
0.115\end{array}$ & $\begin{array}{l}17.2 \\
10.92\end{array}$ \\
\hline
\end{tabular}


$\stackrel{\text { m }}{\$} \quad$ Table B1. Selected drainage-basin characteristics for streamflow-gaging stations in Nebraska and for selected out-of-state stations--Continued

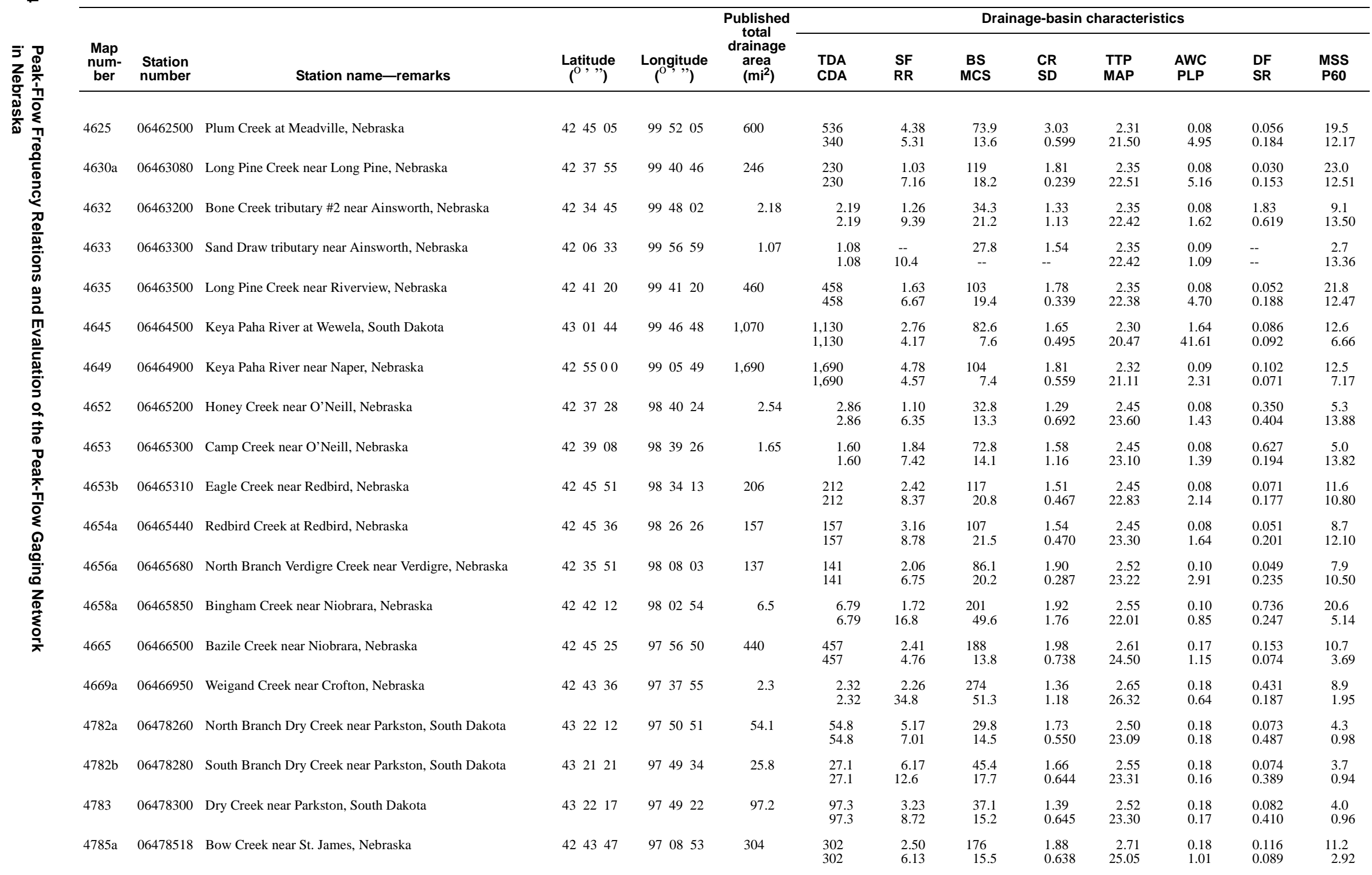


Table B1. Selected drainage-basin characteristics for streamflow-gaging stations in Nebraska and for selected out-of-state stations--Continued

\begin{tabular}{|c|c|c|c|c|c|c|c|c|c|c|c|c|c|}
\hline \multirow[b]{2}{*}{$\underset{\substack{\text { Map } \\
\text { ber }}}{\operatorname{Map}}$} & \multirow[b]{2}{*}{$\begin{array}{l}\text { Station } \\
\text { number }\end{array}$} & \multirow[b]{2}{*}{ Station name-remarks } & \multirow[b]{2}{*}{$\begin{array}{c}\text { Latitude } \\
\left({ }^{0}, ”\right)\end{array}$} & \multirow[b]{2}{*}{$\begin{array}{c}\text { Longitude } \\
\left({ }^{0},{ }^{\prime \prime}\right)\end{array}$} & \multirow{2}{*}{$\begin{array}{c}\text { Published } \\
\text { total } \\
\text { drainage } \\
\text { area } \\
\left(\mathrm{mi}^{2}\right) \\
\end{array}$} & \multicolumn{8}{|c|}{ Drainage-basin characteristics } \\
\hline & & & & & & $\begin{array}{l}\text { TDA } \\
\text { CDA }\end{array}$ & $\begin{array}{l}\text { SF } \\
\text { RR }\end{array}$ & $\begin{array}{l}\text { BS } \\
\text { MCS }\end{array}$ & $\begin{array}{l}\text { CR } \\
\text { SD }\end{array}$ & $\begin{array}{l}\text { TTP } \\
\text { MAP }\end{array}$ & $\begin{array}{l}\text { AWC } \\
\text { PLP }\end{array}$ & $\begin{array}{l}\text { DF } \\
\text { SR }\end{array}$ & $\begin{array}{l}\text { MSS } \\
\text { P60 }\end{array}$ \\
\hline $4785 b$ & 06478520 & West Bow Creek near Fordyce, Nebraska & 424130 & 972506 & 52.7 & $\begin{array}{l}53.0 \\
53.0\end{array}$ & $\begin{array}{c}2.92 \\
10.6\end{array}$ & $\begin{array}{c}146 \\
25.3\end{array}$ & $\begin{array}{l}1.75 \\
0.727\end{array}$ & $\begin{array}{r}2.65 \\
25.90\end{array}$ & $\begin{array}{l}0.19 \\
0.80\end{array}$ & $\begin{array}{l}0.170 \\
0.174\end{array}$ & $\begin{array}{l}9.3 \\
2.03\end{array}$ \\
\hline 4788 & 06478800 & Saddlerock Creek near Canton, South Dakota & 431219 & 964336 & 13.0 & $\begin{array}{l}12.3 \\
12.3\end{array}$ & $\begin{array}{l}2.29 \\
9.20\end{array}$ & $\begin{array}{l}48.9 \\
21.0\end{array}$ & $\begin{array}{l}1.26 \\
0.440\end{array}$ & $\begin{array}{r}2.75 \\
23.51\end{array}$ & $\begin{array}{l}0.18 \\
0.16\end{array}$ & $\begin{array}{l}0.081 \\
0.430\end{array}$ & $\begin{array}{l}3.4 \\
0.77\end{array}$ \\
\hline 4788b & 06478820 & Saddlerock Creek tributary near Beresford, South Dakota & $\begin{array}{lll}43 & 12 & 20\end{array}$ & 964550 & 2.22 & $\begin{array}{l}2.07 \\
2.07\end{array}$ & $\begin{array}{l}3.90 \\
22.1\end{array}$ & $\begin{array}{l}56.4 \\
31.6\end{array}$ & $\begin{array}{l}1.45 \\
1.47\end{array}$ & $\begin{array}{r}2.75 \\
23.51\end{array}$ & $\begin{array}{l}0.18 \\
0.17\end{array}$ & $\begin{array}{l}0.483 \\
0.561\end{array}$ & $\begin{array}{l}4.2 \\
0.79\end{array}$ \\
\hline $4788 \mathrm{c}$ & 06478840 & Saddlerock Creek near Beresford, South Dakota & 431255 & 964932 & 23.1 & $\begin{array}{l}24.7 \\
24.7\end{array}$ & $\begin{array}{l}4.98 \\
9.40\end{array}$ & $\begin{array}{l}47.4 \\
18.8\end{array}$ & $\begin{array}{l}1.56 \\
0.642\end{array}$ & $\begin{array}{r}2.75 \\
23.51\end{array}$ & $\begin{array}{l}0.18 \\
0.15\end{array}$ & $\begin{array}{l}0.081 \\
0.396\end{array}$ & $\begin{array}{l}3.1 \\
0.76\end{array}$ \\
\hline 6000 & 06600000 & Perry Creek at 38th Street, Sioux City, Iowa & 423208 & 962439 & 65.1 & $\begin{array}{l}64.7 \\
64.7\end{array}$ & $\begin{array}{l}4.82 \\
8.21\end{array}$ & $\begin{array}{c}187 \\
13.2\end{array}$ & $\begin{array}{l}1.54 \\
0.739\end{array}$ & $\begin{array}{r}2.85 \\
26.17\end{array}$ & $\begin{array}{l}0.21 \\
0.59\end{array}$ & $\begin{array}{l}0.155 \\
0.071\end{array}$ & $\begin{array}{l}9.7 \\
1.28\end{array}$ \\
\hline 6006 & 06600600 & South Omaha Creek tributary near Walthill, Nebraska & 420600 & 962959 & 2.64 & $\begin{array}{l}2.58 \\
2.58\end{array}$ & $\begin{array}{c}2.20 \\
25.2\end{array}$ & $\begin{array}{l}167 \\
51.1\end{array}$ & $\begin{array}{l}1.40 \\
0.964\end{array}$ & $\begin{array}{r}2.85 \\
27.57\end{array}$ & $\begin{array}{l}0.20 \\
0.43\end{array}$ & $\begin{array}{l}0.388 \\
0.305\end{array}$ & $\begin{array}{l}8.2 \\
1.20\end{array}$ \\
\hline 6007 & 06600700 & South Omaha Creek near Walthill, Nebraska & 420708 & 962924 & 15.1 & $\begin{array}{l}15.3 \\
15.3\end{array}$ & $\begin{array}{c}0.688 \\
12.5\end{array}$ & $\begin{array}{c}212 \\
23.1\end{array}$ & $\begin{array}{l}1.44 \\
0.749\end{array}$ & $\begin{array}{r}2.85 \\
27.57\end{array}$ & $\begin{array}{l}0.20 \\
0.46\end{array}$ & $\begin{array}{l}0.262 \\
0.109\end{array}$ & $\begin{array}{l}8.8 \\
1.19\end{array}$ \\
\hline 6008 & 06600800 & South Omaha Creek tributary $\# 2$ near Walthill, Nebraska & 420818 & 962836 & 1.65 & $\begin{array}{l}1.65 \\
1.65\end{array}$ & $\begin{array}{c}2.29 \\
26.2\end{array}$ & $\begin{array}{c}236 \\
56.3\end{array}$ & $\begin{array}{l}1.43 \\
1.42\end{array}$ & $\begin{array}{r}2.85 \\
27.57\end{array}$ & $\begin{array}{l}0.21 \\
0.60\end{array}$ & $\begin{array}{l}1.22 \\
0.238\end{array}$ & $\begin{array}{c}14.6 \\
1.30\end{array}$ \\
\hline 6009 & 06600900 & South Omaha Creek at Walthill, Nebraska & 420853 & 962858 & 51.2 & $\begin{array}{l}51.2 \\
51.2\end{array}$ & $\begin{array}{l}0.491 \\
5.92\end{array}$ & $\begin{array}{c}300 \\
18.0\end{array}$ & $\begin{array}{l}1.90 \\
0.629\end{array}$ & $\begin{array}{r}2.85 \\
27.72\end{array}$ & $\begin{array}{l}0.20 \\
0.50\end{array}$ & $\begin{array}{l}0.176 \\
0.060\end{array}$ & $\begin{array}{l}9.9 \\
1.20\end{array}$ \\
\hline 6010 & 06601000 & Omaha Creek at Homer, Nebraska & 421928 & 962942 & 168 & $\begin{array}{l}174 \\
174\end{array}$ & $\begin{array}{l}1.64 \\
5.65\end{array}$ & $\begin{array}{c}315 \\
11.3\end{array}$ & $\begin{array}{l}1.59 \\
0.647\end{array}$ & $\begin{array}{r}2.85 \\
27.58\end{array}$ & $\begin{array}{l}0.20 \\
0.53\end{array}$ & $\begin{array}{l}0.155 \\
0.036\end{array}$ & $\begin{array}{c}12.1 \\
1.21\end{array}$ \\
\hline 6067b & 06606790 & Maple Creek near Alta, Iowa & 424456 & 952216 & 15.5 & $\begin{array}{l}16.0 \\
16.0\end{array}$ & $\begin{array}{c}2.28 \\
10.9\end{array}$ & $\begin{array}{l}54.2 \\
21.3\end{array}$ & $\begin{array}{l}1.21 \\
0.385\end{array}$ & $\begin{array}{r}3.05 \\
29.10\end{array}$ & $\begin{array}{l}0.19 \\
0.56\end{array}$ & $\begin{array}{l}0.062 \\
0.392\end{array}$ & $\begin{array}{l}4.9 \\
1.61\end{array}$ \\
\hline 6078 & 06607800 & $\begin{array}{l}\text { South Branch Tekamah Creek tributary near Tekamah, } \\
\text { Nebraska }\end{array}$ & $4145 \quad 15$ & $96 \quad 17 \quad 10$ & 4.08 & $\begin{array}{l}3.91 \\
3.91\end{array}$ & $\begin{array}{l}0.889 \\
23.2\end{array}$ & $\begin{array}{l}193 \\
50.1\end{array}$ & $\begin{array}{l}1.31 \\
1.10\end{array}$ & $\begin{array}{r}2.95 \\
29.33\end{array}$ & $\begin{array}{l}0.20 \\
0.46\end{array}$ & $\begin{array}{l}0.767 \\
0.260\end{array}$ & $\begin{array}{c}13.9 \\
1.08\end{array}$ \\
\hline 6079 & 06607900 & South Branch Tekamah Creek near Tekamah, Nebraska & 414600 & 961659 & 9.73 & $\begin{array}{l}9.58 \\
9.58\end{array}$ & $\begin{array}{l}0.863 \\
4.21\end{array}$ & $\begin{array}{r}57.8 \\
7.7\end{array}$ & $\begin{array}{l}1.50 \\
0.717\end{array}$ & $\begin{array}{r}2.95 \\
29.33\end{array}$ & $\begin{array}{l}0.19 \\
0.41\end{array}$ & $\begin{array}{l}0.313 \\
0.134\end{array}$ & $\begin{array}{c}14.2 \\
0.96\end{array}$ \\
\hline 6080 & 06608000 & Tekamah Creek at Tekamah, Nebraska & 414630 & 961309 & 23.0 & $\begin{array}{l}22.9 \\
22.9\end{array}$ & $\begin{array}{ll}2.04 \\
12.4\end{array}$ & $\begin{array}{l}224 \\
24.7\end{array}$ & $\begin{array}{l}1.50 \\
0.800\end{array}$ & $\begin{array}{r}2.95 \\
29.33\end{array}$ & $\begin{array}{l}0.19 \\
0.39\end{array}$ & $\begin{array}{l}0.305 \\
0.110\end{array}$ & $\begin{array}{c}14.6 \\
0.91\end{array}$ \\
\hline 6085 & 06608500 & Soldier River at Pisgah, Iowa & 414951 & 955550 & 407 & $\begin{array}{l}410 \\
410\end{array}$ & $\begin{array}{l}5.09 \\
4.29\end{array}$ & $\begin{array}{rl}289 & 9 \\
9.0 & -1\end{array}$ & $\begin{array}{l}1.65 \\
0.336\end{array}$ & $\begin{array}{r}3.05 \\
29.64\end{array}$ & $\begin{array}{l}0.21 \\
0.59\end{array}$ & $\begin{array}{l}0.044 \\
0.031\end{array}$ & $\begin{array}{c}11.7 \\
1.28\end{array}$ \\
\hline 6086 & 06608600 & New York Creek near Spiker, Nebraska & 413800 & 962000 & 1.75 & $\begin{array}{l}1.85 \\
1.85\end{array}$ & $\begin{array}{c}3.28 \\
17.7\end{array}$ & $\begin{array}{l}137 \\
25.0\end{array}$ & $\begin{array}{l}1.42 \\
1.42\end{array}$ & $\begin{array}{r}2.95 \\
29.33\end{array}$ & $\begin{array}{l}0.20 \\
0.60\end{array}$ & $\begin{array}{l}0.541 \\
0.182\end{array}$ & $\begin{array}{c}11.6 \\
1.28\end{array}$ \\
\hline 6087 & 06608700 & New York Creek tributary near Spiker, Nebraska & 413823 & 961827 & 1.55 & $\begin{array}{l}1.55 \\
1.55\end{array}$ & $\begin{array}{c}3.49 \\
17.4\end{array}$ & $\begin{array}{l}156 \\
27.2\end{array}$ & $\begin{array}{l}1.28 \\
1.55\end{array}$ & $\begin{array}{r}2.95 \\
29.33\end{array}$ & $\begin{array}{l}0.21 \\
0.60\end{array}$ & $\begin{array}{l}1.29 \\
0.174\end{array}$ & $\begin{array}{c}13.0 \\
1.29\end{array}$ \\
\hline 6088 & 06608800 & New York Creek north of Spiker, Nebraska & 413731 & 961834 & 6.50 & $\begin{array}{l}6.66 \\
6.66\end{array}$ & $\begin{array}{r}2.41 \\
15.7\end{array}$ & $\begin{array}{l}159 \\
31.5\end{array}$ & $\begin{array}{l}1.26 \\
1.11\end{array}$ & $\begin{array}{r}2.95 \\
29.33\end{array}$ & $\begin{array}{l}0.21 \\
0.60\end{array}$ & $\begin{array}{l}0.450 \\
0.198\end{array}$ & $\begin{array}{c}13.2 \\
1.29\end{array}$ \\
\hline 6089 & 06608900 & New York Creek east of Spiker, Nebraska & 413652 & 961614 & 13.9 & $\begin{array}{l}14.2 \\
14.2\end{array}$ & $\begin{array}{c}2.45 \\
13.1\end{array}$ & $\begin{array}{c}162 \\
29.5\end{array}$ & $\begin{array}{l}1.37 \\
1.32\end{array}$ & $\begin{array}{r}2.95 \\
29.49\end{array}$ & $\begin{array}{l}0.21 \\
0.60\end{array}$ & $\begin{array}{l}0.634 \\
0.183\end{array}$ & $\begin{array}{c}13.5 \\
1.29\end{array}$ \\
\hline
\end{tabular}


Table B1. Selected drainage-basin characteristics for streamflow-gaging stations in Nebraska and for selected out-of-state stations--Continued

\begin{tabular}{|c|c|c|c|c|c|c|c|c|c|c|c|c|c|c|}
\hline \multirow{2}{*}{\multicolumn{2}{|c|}{ 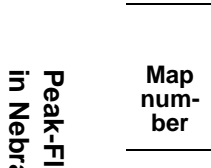 }} & \multirow[b]{2}{*}{$\begin{array}{l}\text { Station } \\
\text { number }\end{array}$} & \multirow[b]{2}{*}{ Station name-remarks } & \multirow[b]{2}{*}{$\begin{array}{c}\text { Latitude } \\
\left({ }^{0},{ }^{\prime}\right)\end{array}$} & \multirow[b]{2}{*}{$\underset{\left(0,{ }^{0}\right)}{\text { Longitude }}$} & \multirow{2}{*}{$\begin{array}{c}\text { Published } \\
\text { total } \\
\text { drainage } \\
\text { area } \\
\left(\mathrm{mi}^{2}\right)\end{array}$} & \multicolumn{8}{|c|}{ Drainage-basin characteristics } \\
\hline & & & & & & & $\begin{array}{l}\text { TDA } \\
\text { CDA }\end{array}$ & $\begin{array}{l}\text { SF } \\
\text { RR }\end{array}$ & $\begin{array}{l}\text { BS } \\
\text { MCS }\end{array}$ & $\begin{array}{l}\text { CR } \\
\text { SD }\end{array}$ & $\begin{array}{l}\text { TTP } \\
\text { MAP }\end{array}$ & $\begin{array}{l}\text { AWC } \\
\text { PLP }\end{array}$ & $\begin{array}{l}\text { DF } \\
\text { SR }\end{array}$ & $\begin{array}{l}\text { MSS } \\
\text { P60 }\end{array}$ \\
\hline จ $\frac{\pi}{\Phi}$ & 6090 & 06609000 & New York Creek at Herman, Nebraska & 413939 & 961209 & 25.4 & $\begin{array}{l}26.1 \\
26.1\end{array}$ & $\begin{array}{l}1.82 \\
11.2\end{array}$ & $\begin{array}{l}232 \\
24.9\end{array}$ & $\begin{array}{l}1.72 \\
1.31\end{array}$ & $\begin{array}{r}2.95 \\
29.67\end{array}$ & $\begin{array}{l}0.21 \\
0.60\end{array}$ & $\begin{array}{l}0.537 \\
0.107\end{array}$ & $\begin{array}{c}14.0 \\
1.30\end{array}$ \\
\hline Ф్ & 6106 & 06610600 & Mosquito Creek at Neola, Iowa & 412635 & 953641 & 131 & $\begin{array}{l}130 \\
130\end{array}$ & $\begin{array}{l}8.67 \\
5.44\end{array}$ & $\begin{array}{l}233 \\
7.8\end{array}$ & $\begin{array}{l}1.96 \\
0.333\end{array}$ & $\begin{array}{r}3.05 \\
32.05\end{array}$ & $\begin{array}{l}0.21 \\
0.59\end{array}$ & $\begin{array}{l}0.023 \\
0.033\end{array}$ & $\begin{array}{c}11.2 \\
1.29\end{array}$ \\
\hline 帝 & 6107 & 06610700 & Big Papillion Creek near Orum, Nebraska & 413244 & 961309 & 8.52 & $\begin{array}{l}8.52 \\
8.52\end{array}$ & $\begin{array}{l}3.05 \\
10.4\end{array}$ & $\begin{array}{l}140 \\
14.1\end{array}$ & $\begin{array}{l}1.53 \\
0.827\end{array}$ & $\begin{array}{r}2.95 \\
30.07\end{array}$ & $\begin{array}{l}0.20 \\
0.60\end{array}$ & $\begin{array}{l}0.352 \\
0.100\end{array}$ & $\begin{array}{l}9.6 \\
1.27\end{array}$ \\
\hline$\stackrel{2}{0}$ & 6524 & 06652400 & Watson Draw near Lost Springs, Wyoming & 424519 & 1045729 & 6.95 & $\begin{array}{l}6.41 \\
6.41\end{array}$ & $\begin{array}{c}2.39 \\
38.8\end{array}$ & $\begin{array}{l}143 \\
100\end{array}$ & $\begin{array}{l}1.15 \\
0.925\end{array}$ & $\begin{array}{r}1.65 \\
14.25\end{array}$ & $\begin{array}{l}0.12 \\
0.65\end{array}$ & $\begin{array}{l}0.312 \\
0.701\end{array}$ & $\begin{array}{c}19.2 \\
1.58\end{array}$ \\
\hline 今 & 6775 & 06677500 & Horse Creek near Lyman, Nebraska & 415621 & 1035912 & 1,570 & $\begin{array}{l}1,700 \\
1,530\end{array}$ & $\begin{array}{c}5.42 \\
18.1\end{array}$ & $\begin{array}{c}138 \\
27.4\end{array}$ & $\begin{array}{l}1.90 \\
0.500\end{array}$ & $\begin{array}{r}1.70 \\
15.12\end{array}$ & $\begin{array}{l}0.11 \\
1.51\end{array}$ & $\begin{array}{l}0.063 \\
0.198\end{array}$ & $\begin{array}{c}14.9 \\
4.18\end{array}$ \\
\hline$\underset{\S}{m}$ & 6870 & 06687000 & Blue Creek near Lewellen, Nebraska & 412007 & 1021021 & 1,190 & $\begin{array}{r}1,140 \\
106\end{array}$ & $\begin{array}{c}10.3 \\
4.05\end{array}$ & $\begin{array}{l}138 \\
11.8\end{array}$ & $\begin{array}{l}7.96 \\
0.502\end{array}$ & $\begin{array}{r}2.06 \\
16.39\end{array}$ & $\begin{array}{l}0.08 \\
5.26\end{array}$ & $\begin{array}{l}0.113 \\
0.086\end{array}$ & $\begin{array}{l}18.2 \\
11.79\end{array}$ \\
\hline 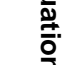 & 6876 & 06687600 & Ash Hollow near Oshkosh, Nebraska & $41 \quad 1505$ & 1022028 & 54.9 & $\begin{array}{l}45.7 \\
45.7\end{array}$ & $\begin{array}{l}1.84 \\
5.09\end{array}$ & $\begin{array}{l}32.8 \\
13.0\end{array}$ & $\begin{array}{l}1.37 \\
0.398\end{array}$ & $\begin{array}{r}2.05 \\
18.41\end{array}$ & $\begin{array}{l}0.19 \\
0.58\end{array}$ & $\begin{array}{l}0.087 \\
0.397\end{array}$ & $\begin{array}{l}2.4 \\
1.26\end{array}$ \\
\hline$\stackrel{0}{\stackrel{0}{F}}$ & 6920 & 06692000 & Birdwood Creek near Hershey, Nebraska & 411319 & 1010411 & 940 & $\begin{array}{c}963 . \\
78.0\end{array}$ & $\begin{array}{l}10.8 \\
4.81\end{array}$ & $\begin{array}{l}173 \\
12.6\end{array}$ & $\begin{array}{l}7.26 \\
0.864\end{array}$ & $\begin{array}{r}2.20 \\
18.93\end{array}$ & $\begin{array}{l}0.08 \\
5.75\end{array}$ & $\begin{array}{l}0.103 \\
0.073\end{array}$ & $\begin{array}{l}20.8 \\
12.77\end{array}$ \\
\hline $\mathbb{D}_{0}^{0}$ & 7626 & 06762600 & Lodgepole Creek tributary \#2 near Albin, Wyoming & 411910 & 1040449 & 5.69 & $\begin{array}{l}5.67 \\
5.67\end{array}$ &.-- & $\begin{array}{c}35.2 \\
--\end{array}$ & 1.22 & $\begin{array}{r}1.79 \\
18.00\end{array}$ & $\begin{array}{l}0.13 \\
0.53\end{array}$ & $\begin{array}{l}-- \\
--\end{array}$ & $\begin{array}{l}7.6 \\
4.67\end{array}$ \\
\hline $\begin{array}{l}\frac{\pi}{1} \\
\frac{\pi}{0}\end{array}$ & 7632 & 06763200 & Lodgepole Creek tributary near Sunol, Nebraska & $41 \quad 1000$ & 1024325 & 15.6 & $\begin{array}{l}18.1 \\
18.1\end{array}$ & $\begin{array}{c}2.40 \\
10.7\end{array}$ & $\begin{array}{l}47.9 \\
20.5\end{array}$ & $\begin{array}{l}1.67 \\
0.516\end{array}$ & $\begin{array}{r}2.05 \\
17.29\end{array}$ & $\begin{array}{l}0.14 \\
0.47\end{array}$ & $\begin{array}{l}0.166 \\
0.428\end{array}$ & $\begin{array}{l}8.5 \\
1.89\end{array}$ \\
\hline ڤి & 7671 & 06767100 & South Fork Plum Creek tributary near Farnam, Nebraska & 404206 & 1001521 & 9.81 & $\begin{array}{l}10.4 \\
10.4\end{array}$ & $\begin{array}{c}4.89 \\
10.2\end{array}$ & $\begin{array}{l}102 \\
16.9\end{array}$ & $\begin{array}{l}1.88 \\
1.11\end{array}$ & $\begin{array}{r}2.35 \\
20.99\end{array}$ & $\begin{array}{l}0.20 \\
0.60\end{array}$ & $\begin{array}{l}0.192 \\
0.165\end{array}$ & $\begin{array}{c}13.7 \\
1.30\end{array}$ \\
\hline 范 & 7672 & 06767200 & North Fork Plum Creek tributary near Farnam, Nebraska & $4042 \quad 18$ & 1001423 & 1.83 & $\begin{array}{l}1.83 \\
1.83\end{array}$ & $\begin{array}{l}4.35 \\
15.2\end{array}$ & $\begin{array}{l}64.4 \\
11.6\end{array}$ & $\begin{array}{l}1.45 \\
1.65\end{array}$ & $\begin{array}{r}2.35 \\
21.01\end{array}$ & $\begin{array}{l}0.20 \\
0.60\end{array}$ & $\begin{array}{l}0.547 \\
0.180\end{array}$ & $\begin{array}{c}13.7 \\
1.30\end{array}$ \\
\hline$\stackrel{\Phi}{\Sigma}$ & 7673 & 06767300 & Plum Creek tributary at Farnam, Nebraska & 404208 & 1001252 & 19.8 & $\begin{array}{l}19.3 \\
19.3\end{array}$ & $\begin{array}{l}4.24 \\
9.74\end{array}$ & $\begin{array}{l}87.7 \\
14.5\end{array}$ & $\begin{array}{l}1.73 \\
1.09\end{array}$ & $\begin{array}{r}2.35 \\
21.17\end{array}$ & $\begin{array}{l}0.20 \\
0.60\end{array}$ & $\begin{array}{l}0.259 \\
0.165\end{array}$ & $\begin{array}{c}13.8 \\
1.30\end{array}$ \\
\hline 긋 & 7674 & 06767400 & North Plum Creek near Farnam, Nebraska & 404354 & 1000956 & 38.3 & $\begin{array}{l}40.5 \\
40.5\end{array}$ & $\begin{array}{l}4.61 \\
6.20\end{array}$ & $\begin{array}{c}139 \\
13.1\end{array}$ & $\begin{array}{l}1.99 \\
0.694\end{array}$ & $\begin{array}{r}2.35 \\
21.57\end{array}$ & $\begin{array}{l}0.20 \\
0.60\end{array}$ & $\begin{array}{l}0.148 \\
0.094\end{array}$ & $\begin{array}{c}15.4 \\
1.30\end{array}$ \\
\hline & $7674 \mathrm{~b}$ & 06767410 & Plum Creek near Farnam, Nebraska & $4041 \quad 13$ & 1000841 & 80.4 & $\begin{array}{l}80.6 \\
80.6\end{array}$ & $\begin{array}{l}3.63 \\
5.93\end{array}$ & $\begin{array}{c}126 \\
12.6\end{array}$ & $\begin{array}{l}1.70 \\
0.792\end{array}$ & $\begin{array}{r}2.35 \\
21.50\end{array}$ & $\begin{array}{l}0.20 \\
0.60\end{array}$ & $\begin{array}{l}0.161 \\
0.100\end{array}$ & $\begin{array}{c}14.2 \\
1.30\end{array}$ \\
\hline & 7675 & 06767500 & Plum Creek near Smithfield, Nebraska & 403939 & 994159 & 229 & $\begin{array}{l}215 \\
215\end{array}$ & $\begin{array}{l}9.75 \\
4.47\end{array}$ & $\begin{array}{r}93.2 \\
6.4\end{array}$ & $\begin{array}{l}2.53 \\
0.841\end{array}$ & $\begin{array}{r}2.37 \\
21.82\end{array}$ & $\begin{array}{l}0.20 \\
0.60\end{array}$ & $\begin{array}{l}0.200 \\
0.069\end{array}$ & $\begin{array}{c}11.9 \\
1.32\end{array}$ \\
\hline & $7680 \mathrm{~b}$ & 06768050 & Buffalo Creek tributary \#1 near Buffalo, Nebraska & 410044 & 994848 & 2.08 & $\begin{array}{l}2.09 \\
2.09\end{array}$ & $\begin{array}{l}1.07 \\
8.69\end{array}$ & $\begin{array}{l}35.7 \\
62.2\end{array}$ & $\begin{array}{l}1.55 \\
1.77\end{array}$ & $\begin{array}{r}2.35 \\
23.54\end{array}$ & $\begin{array}{l}0.20 \\
0.60\end{array}$ & $\begin{array}{l}1.44 \\
1.74\end{array}$ & $\begin{array}{c}21.2 \\
1.30\end{array}$ \\
\hline & 7681 & 06768100 & East Buffalo Creek near Buffalo, Nebraska & 410017 & 995014 & 5.21 & $\begin{array}{l}5.22 \\
5.22\end{array}$ & $\begin{array}{c}5.86 \\
14.1\end{array}$ & $\begin{array}{c}140 \\
23.5\end{array}$ & $\begin{array}{l}1.84 \\
1.50\end{array}$ & $\begin{array}{r}2.35 \\
23.54\end{array}$ & $\begin{array}{l}0.20 \\
0.60\end{array}$ & $\begin{array}{l}0.959 \\
0.168\end{array}$ & $\begin{array}{c}16.2 \\
1.30\end{array}$ \\
\hline & 7682 & 06768200 & Buffalo Creek at Buffalo, Nebraska & 405920 & 994951 & 33.5 & $\begin{array}{l}32.7 \\
32.7\end{array}$ & $\begin{array}{l}2.31 \\
8.67\end{array}$ & $\begin{array}{c}124 \\
16.4\end{array}$ & $\begin{array}{l}1.87 \\
1.34\end{array}$ & $\begin{array}{r}2.35 \\
23.54\end{array}$ & $\begin{array}{l}0.20 \\
0.58\end{array}$ & $\begin{array}{l}0.674 \\
0.132\end{array}$ & $\begin{array}{c}19.3 \\
1.28\end{array}$ \\
\hline
\end{tabular}


Table B1. Selected drainage-basin characteristics for streamflow-gaging stations in Nebraska and for selected out-of-state stations--Continued

\begin{tabular}{|c|c|c|c|c|c|c|c|c|c|c|c|c|c|}
\hline \multirow[b]{2}{*}{$\underset{\text { num- }}{\text { Map }}$} & \multirow[b]{2}{*}{$\begin{array}{c}\text { Station } \\
\text { number }\end{array}$} & \multirow[b]{2}{*}{ Station name-remarks } & \multirow[b]{2}{*}{$\begin{array}{c}\text { Latitude } \\
\left({ }^{0}, \%\right)\end{array}$} & \multirow[b]{2}{*}{$\begin{array}{c}\text { Longitude } \\
\left(0,{ }^{\circ},{ }^{\prime}\right)\end{array}$} & \multirow{2}{*}{$\begin{array}{c}\text { Published } \\
\text { total } \\
\text { drainage } \\
\text { area } \\
\left(\mathrm{mi}^{2}\right)\end{array}$} & \multicolumn{8}{|c|}{ Drainage-basin characteristics } \\
\hline & & & & & & $\begin{array}{l}\text { TDA } \\
\text { CDA }\end{array}$ & $\begin{array}{l}\text { SF } \\
\text { RR }\end{array}$ & $\begin{array}{c}\text { BS } \\
\text { MCS }\end{array}$ & $\begin{array}{l}\text { CR } \\
\text { SD }\end{array}$ & $\begin{array}{l}\text { TTP } \\
\text { MAP }\end{array}$ & $\begin{array}{l}\text { AWC } \\
\text { PLP }\end{array}$ & $\begin{array}{l}\text { DF } \\
\text { SR }\end{array}$ & $\begin{array}{l}\text { MSS } \\
\text { P60 }\end{array}$ \\
\hline 7684 & 06768400 & West Buffalo Creek near Buffalo, Nebraska & 405921 & $9952 \quad 21$ & 17.1 & $\begin{array}{l}17.0 \\
17.0\end{array}$ & $\begin{array}{c}5.08 \\
12.1\end{array}$ & $\begin{array}{l}150 \\
24.7\end{array}$ & $\begin{array}{l}1.93 \\
1.58\end{array}$ & $\begin{array}{r}2.35 \\
23.50\end{array}$ & $\begin{array}{l}0.20 \\
0.59\end{array}$ & $\begin{array}{l}0.881 \\
0.165\end{array}$ & $\begin{array}{c}25.5 \\
1.29\end{array}$ \\
\hline 7685 & 06768500 & Buffalo Creek near Darr, Nebraska & 405405 & 995005 & 63 & $\begin{array}{l}64.8 \\
64.8\end{array}$ & $\begin{array}{l}4.47 \\
8.03\end{array}$ & $\begin{array}{c}121 \\
17.4\end{array}$ & $\begin{array}{l}1.90 \\
1.44\end{array}$ & $\begin{array}{r}2.35 \\
23.54\end{array}$ & $\begin{array}{l}0.20 \\
0.59\end{array}$ & $\begin{array}{l}0.617 \\
0.145\end{array}$ & $\begin{array}{c}21.7 \\
1.30\end{array}$ \\
\hline 7690 & 06769000 & Buffalo Creek near Overton, Nebraska & 404400 & 993020 & 175 & $\begin{array}{l}190 \\
190\end{array}$ & $\begin{array}{l}9.88 \\
5.96\end{array}$ & $\begin{array}{l}106 \\
8.6\end{array}$ & $\begin{array}{l}2.13 \\
1.18\end{array}$ & $\begin{array}{r}2.39 \\
23.05\end{array}$ & $\begin{array}{l}0.20 \\
0.62\end{array}$ & $\begin{array}{l}0.305 \\
0.082\end{array}$ & $\begin{array}{c}15.8 \\
1.48\end{array}$ \\
\hline 7692 & 06769200 & Elm Creek near Sumner, Nebraska & 405124 & $9932 \quad 21$ & 14.94 & $\begin{array}{l}14.9 \\
14.9\end{array}$ & $\begin{array}{l}2.97 \\
4.82\end{array}$ & $\begin{array}{l}34.2 \\
18.7\end{array}$ & $\begin{array}{l}1.59 \\
0.649\end{array}$ & $\begin{array}{r}2.45 \\
21.99\end{array}$ & $\begin{array}{l}0.20 \\
0.60\end{array}$ & $\begin{array}{l}0.268 \\
0.547\end{array}$ & $\begin{array}{c}16.5 \\
1.30\end{array}$ \\
\hline 7693 & 06769300 & Elm Creek tributary \#2 near Overton, Nebraska & 405102 & $9932 \quad 21$ & 5.62 & $\begin{array}{l}5.65 \\
5.65\end{array}$ & $-\overline{4} .18$ & $\begin{array}{c}34.4 \\
--\end{array}$ & $\begin{array}{l}1.59 \\
--\end{array}$ & $\begin{array}{r}2.45 \\
21.99\end{array}$ & $\begin{array}{l}0.20 \\
0.60\end{array}$ & $\begin{array}{l}-- \\
--\end{array}$ & $\begin{array}{c}20.2 \\
1.30\end{array}$ \\
\hline 7695 & 06769500 & Elm Creek near Overton, Nebraska & 405040 & 993020 & 31.0 & $\begin{array}{l}33.0 \\
33.0\end{array}$ & $\begin{array}{l}2.31 \\
3.84\end{array}$ & $\begin{array}{l}37.6 \\
16.3\end{array}$ & $\begin{array}{l}1.60 \\
0.528\end{array}$ & $\begin{array}{r}2.45 \\
21.99\end{array}$ & $\begin{array}{l}0.20 \\
0.60\end{array}$ & $\begin{array}{l}0.182 \\
0.433\end{array}$ & $\begin{array}{c}17.2 \\
1.30\end{array}$ \\
\hline 7706 & 06770600 & Wood River tributary near Lodi, Nebraska & 411157 & 995021 & 2.02 & $\begin{array}{l}2.05 \\
2.05\end{array}$ & $\begin{array}{c}2.77 \\
18.1\end{array}$ & $\begin{array}{l}77.4 \\
28.9\end{array}$ & $\begin{array}{l}1.50 \\
1.97\end{array}$ & $\begin{array}{r}2.35 \\
23.54\end{array}$ & $\begin{array}{l}0.20 \\
0.60\end{array}$ & $\begin{array}{l}1.46 \\
0.374\end{array}$ & $\begin{array}{c}23.3 \\
1.34\end{array}$ \\
\hline 7707 & 06770700 & Wood River near Lodi, Nebraska & $41 \quad 1014$ & $9948 \quad 17$ & 12.9 & $\begin{array}{l}11.0 \\
11.0\end{array}$ & $\begin{array}{c}2.66 \\
10.8\end{array}$ & $\begin{array}{c}102 \\
21.4\end{array}$ & $\begin{array}{l}2.38 \\
1.86\end{array}$ & $\begin{array}{r}2.35 \\
23.54\end{array}$ & $\begin{array}{l}0.20 \\
0.60\end{array}$ & $\begin{array}{l}0.816 \\
0.211\end{array}$ & $\begin{array}{l}21.7 \\
1.36\end{array}$ \\
\hline 7708 & 06770800 & Wood River near Oconto, Nebraska & 410946 & 994737 & 26.4 & $\begin{array}{l}24.6 \\
24.6\end{array}$ & $\begin{array}{l}1.42 \\
8.84\end{array}$ & $\begin{array}{l}48.2 \\
20.3\end{array}$ & $\begin{array}{l}1.94 \\
1.78\end{array}$ & $\begin{array}{r}2.35 \\
23.54\end{array}$ & $\begin{array}{l}0.20 \\
0.60\end{array}$ & $\begin{array}{l}0.814 \\
0.422\end{array}$ & $\begin{array}{c}21.0 \\
1.35\end{array}$ \\
\hline 7709 & 06770900 & Wood River at Oconto, Nebraska & 410849 & 994526 & 44.8 & $\begin{array}{l}42.8 \\
42.8\end{array}$ & $\begin{array}{l}1.51 \\
8.01\end{array}$ & $\begin{array}{l}136 \\
18.7\end{array}$ & $\begin{array}{l}1.82 \\
1.67\end{array}$ & $\begin{array}{r}2.35 \\
23.54\end{array}$ & $\begin{array}{l}0.20 \\
0.60\end{array}$ & $\begin{array}{l}0.771 \\
0.137\end{array}$ & $\begin{array}{c}21.4 \\
1.35\end{array}$ \\
\hline $7709 \mathrm{~b}$ & 06770910 & Wood River near Lomax, Nebraska & $\begin{array}{lll}4103 & 39\end{array}$ & 994050 & 79.6 & $\begin{array}{l}76.3 \\
74.6\end{array}$ & $\begin{array}{l}2.74 \\
7.31\end{array}$ & $\begin{array}{l}116 \\
10.8\end{array}$ & $\begin{array}{l}1.88 \\
2.16\end{array}$ & $\begin{array}{r}2.36 \\
23.54\end{array}$ & $\begin{array}{l}0.20 \\
0.60\end{array}$ & $\begin{array}{l}0.978 \\
0.093\end{array}$ & $\begin{array}{c}20.3 \\
1.36\end{array}$ \\
\hline 7710 & 06771000 & Wood River near Riverdale, Nebraska & 404756 & $99 \quad 1147$ & 379 & $\begin{array}{l}369 \\
369\end{array}$ & $\begin{array}{l}6.08 \\
4.20\end{array}$ & $\begin{array}{r}94.5 \\
7.0\end{array}$ & $\begin{array}{l}2.44 \\
0.992\end{array}$ & $\begin{array}{r}2.43 \\
22.76\end{array}$ & $\begin{array}{l}0.20 \\
0.60\end{array}$ & $\begin{array}{l}0.339 \\
0.075\end{array}$ & $\begin{array}{c}16.9 \\
1.35\end{array}$ \\
\hline 7715 & 06771500 & Wood River near Gibbon, Nebraska & 404617 & 984751 & 572 & $\begin{array}{l}526 \\
526\end{array}$ & $\begin{array}{c}12.4 \\
3.68\end{array}$ & $\begin{array}{r}79.4 \\
6.0\end{array}$ & $\begin{array}{l}2.83 \\
0.950\end{array}$ & $\begin{array}{r}2.44 \\
23.36\end{array}$ & $\begin{array}{l}0.20 \\
0.59\end{array}$ & $\begin{array}{l}0.281 \\
0.075\end{array}$ & $\begin{array}{c}14.4 \\
1.36\end{array}$ \\
\hline 7720 & 06772000 & Wood River near Alda, Nebraska & $4051 \quad 10$ & $98 \quad 2819$ & 599 & $\begin{array}{l}600 \\
600\end{array}$ & $\begin{array}{c}13.0 \\
3.64\end{array}$ & $\begin{array}{r}72.3 \\
5.8\end{array}$ & $\begin{array}{l}3.12 \\
0.965\end{array}$ & $\begin{array}{r}2.45 \\
23.54\end{array}$ & $\begin{array}{l}0.20 \\
0.59\end{array}$ & $\begin{array}{l}0.265 \\
0.080\end{array}$ & $\begin{array}{c}13.3 \\
1.42\end{array}$ \\
\hline 7755 & 06775500 & Middle Loup River at Dunning, Nebraska & 414949 & 1000559 & 1,830 & $\begin{array}{c}1,840 \\
\quad 79.0\end{array}$ & $\begin{array}{l}122 \\
3.98\end{array}$ & $\begin{array}{l}173 \\
12.0\end{array}$ & $\begin{array}{l}13.1 \\
3.21\end{array}$ & $\begin{array}{r}2.20 \\
19.75\end{array}$ & $\begin{array}{l}0.08 \\
5.64\end{array}$ & $\begin{array}{l}0.278 \\
0.069\end{array}$ & $\begin{array}{l}21.3 \\
12.72\end{array}$ \\
\hline 7759 & 06775900 & Dismal River near Thedford, Nebraska & 414645 & 1003129 & 966 & $\begin{array}{l}966 \\
30.0\end{array}$ & $\begin{array}{l}82.6 \\
4.06\end{array}$ & $\begin{array}{l}286 \\
13.5\end{array}$ & $\begin{array}{c}17.8 \\
3.37\end{array}$ & $\begin{array}{r}2.18 \\
18.54\end{array}$ & $\begin{array}{l}0.08 \\
5.72\end{array}$ & $\begin{array}{l}0.300 \\
0.047\end{array}$ & $\begin{array}{l}26.8 \\
12.80\end{array}$ \\
\hline 7765 & 06776500 & Dismal River at Dunning, Nebraska & 414923 & 1000605 & 2,040 & $\begin{array}{c}2,040 \\
45.0\end{array}$ & $\begin{array}{c}115 \\
3.49\end{array}$ & $\begin{array}{l}242 \\
11.2\end{array}$ & $\begin{array}{c}19.1 \\
3.49\end{array}$ & $\begin{array}{r}2.22 \\
19.84\end{array}$ & $\begin{array}{l}0.08 \\
5.80\end{array}$ & $\begin{array}{l}0.267 \\
0.046\end{array}$ & $\begin{array}{l}25.2 \\
12.85\end{array}$ \\
\hline 7770 & 06777000 & Middle Loup River near Milburn, Nebraska & 414902 & $9958 \quad 15$ & 3,690 & $\begin{array}{r}3,960 \\
360\end{array}$ & $\begin{array}{c}34.0 \\
3.20\end{array}$ & $\begin{array}{l}220 \\
11.6\end{array}$ & $\begin{array}{l}7.83 \\
1.17\end{array}$ & $\begin{array}{r}2.21 \\
19.84\end{array}$ & $\begin{array}{l}0.08 \\
5.73\end{array}$ & $\begin{array}{l}0.100 \\
0.053\end{array}$ & $\begin{array}{l}23.3 \\
12.79\end{array}$ \\
\hline 7775 & 06777500 & Middle Loup River at Walworth, Nebraska & 413920 & 993359 & 4,340 & $\begin{array}{r}4,320 \\
433\end{array}$ & $\begin{array}{c}38.8 \\
3.09\end{array}$ & $\begin{array}{l}211 \\
10.8\end{array}$ & $\begin{array}{l}8.19 \\
1.40\end{array}$ & $\begin{array}{r}2.23 \\
20.18\end{array}$ & $\begin{array}{l}0.08 \\
5.59\end{array}$ & $\begin{array}{l}0.196 \\
0.051\end{array}$ & $\begin{array}{l}23.1 \\
12.49\end{array}$ \\
\hline
\end{tabular}


Table B1. Selected drainage-basin characteristics for streamflow-gaging stations in Nebraska and for selected out-of-state stations--Continued

\begin{tabular}{|c|c|c|c|c|c|c|c|c|c|c|c|c|c|c|}
\hline \multirow{2}{*}{\multicolumn{2}{|c|}{ 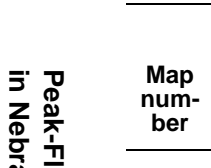 }} & \multirow[b]{2}{*}{$\begin{array}{l}\text { Station } \\
\text { number }\end{array}$} & \multirow[b]{2}{*}{ Station name-remarks } & \multirow[b]{2}{*}{$\begin{array}{c}\text { Latitude } \\
\left({ }^{0},{ }^{\prime}\right)\end{array}$} & \multirow[b]{2}{*}{$\begin{array}{c}\text { Longitude } \\
\left({ }^{0},{ }^{\prime}\right)\end{array}$} & \multirow{2}{*}{$\begin{array}{l}\text { Published } \\
\text { total } \\
\text { drainage } \\
\text { area } \\
\left(\mathrm{mi}^{2}\right)\end{array}$} & \multicolumn{8}{|c|}{ Drainage-basin characteristics } \\
\hline & & & & & & & $\begin{array}{l}\text { TDA } \\
\text { CDA }\end{array}$ & $\begin{array}{l}\text { SF } \\
\text { RR }\end{array}$ & $\begin{array}{l}\text { BS } \\
\text { MCS }\end{array}$ & $\begin{array}{l}\text { CR } \\
\text { SD }\end{array}$ & $\begin{array}{l}\text { TTP } \\
\text { MAP }\end{array}$ & $\begin{array}{l}\text { AWC } \\
\text { PLP }\end{array}$ & $\begin{array}{l}\text { DF } \\
\text { SR }\end{array}$ & $\begin{array}{l}\text { MSS } \\
\text { P60 }\end{array}$ \\
\hline ब & 7776 & 06777600 & Lillian Creek tributary near Broken Bow, Nebraska & 413012 & 993929 & 2.02 & $\begin{array}{l}2.01 \\
2.01\end{array}$ & $\begin{array}{l}1.36 \\
6.21\end{array}$ & $\begin{array}{r}11.7 \\
7.3\end{array}$ & $\begin{array}{l}1.44 \\
2.40\end{array}$ & $\begin{array}{r}2.35 \\
22.57\end{array}$ & $\begin{array}{l}0.20 \\
0.60\end{array}$ & $\begin{array}{l}1.99 \\
0.624\end{array}$ & $\begin{array}{c}26.8 \\
1.30\end{array}$ \\
\hline 을 & 7777 & 06777700 & Lillian Creek near Broken Bow, Nebraska & 413035 & 993926 & 4.77 & $\begin{array}{l}4.71 \\
4.71\end{array}$ & $\begin{array}{l}1.85 \\
17.4\end{array}$ & $\begin{array}{c}134 \\
28.1\end{array}$ & $\begin{array}{l}1.62 \\
1.22\end{array}$ & $\begin{array}{r}2.35 \\
22.63\end{array}$ & $\begin{array}{l}0.20 \\
0.60\end{array}$ & $\begin{array}{l}1.06 \\
0.210\end{array}$ & $\begin{array}{c}26.4 \\
1.30\end{array}$ \\
\hline 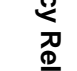 & 7778 & 06777800 & Lillian Creek tributary near Walworth, Nebraska & 413732 & $9934 \quad 12$ & 2.04 & $\begin{array}{l}2.05 \\
2.05\end{array}$ & $\begin{array}{c}3.58 \\
18.4\end{array}$ & $\begin{array}{c}185 \\
53.3\end{array}$ & $\begin{array}{l}1.68 \\
1.36\end{array}$ & $\begin{array}{r}2.45 \\
23.54\end{array}$ & $\begin{array}{l}0.20 \\
0.60\end{array}$ & $\begin{array}{l}0.488 \\
0.288\end{array}$ & $\begin{array}{c}23.6 \\
1.34\end{array}$ \\
\hline$\stackrel{\overline{0}}{\overline{0}}$ & 7780 & 06778000 & Middle Loup River at Sargent, Nebraska & 413735 & $99 \quad 22 \quad 15$ & 4,480 & $\begin{array}{r}4,490 \\
475\end{array}$ & $\begin{array}{c}41.2 \\
3.02\end{array}$ & $\begin{array}{l}208 \\
10.4\end{array}$ & $\begin{array}{l}8.28 \\
1.57\end{array}$ & $\begin{array}{r}2.23 \\
20.30\end{array}$ & $\begin{array}{l}0.09 \\
5.43\end{array}$ & $\begin{array}{l}0.284 \\
0.050\end{array}$ & $\begin{array}{l}22.8 \\
12.15\end{array}$ \\
\hline $\begin{array}{l}\infty \\
\stackrel{\infty}{3}\end{array}$ & 7790 & 06779000 & Middle Loup River at Arcadia, Nebraska & 412519 & 990809 & 5,040 & $\begin{array}{r}5,020 \\
820\end{array}$ & $\begin{array}{c}29.5 \\
3.10\end{array}$ & $\begin{array}{c}191 \\
9.3\end{array}$ & $\begin{array}{l}6.63 \\
1.30\end{array}$ & $\begin{array}{r}2.25 \\
20.67\end{array}$ & $\begin{array}{l}0.09 \\
5.19\end{array}$ & $\begin{array}{l}0.310 \\
0.049\end{array}$ & $\begin{array}{l}22.5 \\
11.62\end{array}$ \\
\hline$\underset{\Phi}{\mathbf{m}}$ & 7800 & 06780000 & Middle Loup River at Rockville, Nebraska & 410638 & $98 \quad 50 \quad 19$ & 5,310 & $\begin{array}{l}5,310 \\
1,090\end{array}$ & $\begin{array}{c}24.1 \\
3.02\end{array}$ & $\begin{array}{l}191 \\
9.1\end{array}$ & $\begin{array}{l}6.45 \\
1.30\end{array}$ & $\begin{array}{r}2.26 \\
20.88\end{array}$ & $\begin{array}{l}0.10 \\
4.99\end{array}$ & $\begin{array}{l}0.340 \\
0.048\end{array}$ & $\begin{array}{l}22.4 \\
11.18\end{array}$ \\
\hline 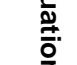 & 7825 & 06782500 & South Loup River at Ravenna, Nebraska & 410041 & 985444 & 1,570 & $\begin{array}{r}1,540 \\
842\end{array}$ & $\begin{array}{c}17.0 \\
3.09\end{array}$ & $\begin{array}{l}170 \\
6.0\end{array}$ & $\begin{array}{l}4.41 \\
1.34\end{array}$ & $\begin{array}{r}2.37 \\
22.61\end{array}$ & $\begin{array}{l}0.16 \\
2.31\end{array}$ & $\begin{array}{l}0.445 \\
0.035\end{array}$ & $\begin{array}{c}18.4 \\
5.40\end{array}$ \\
\hline$\stackrel{0}{\stackrel{0}{*}}$ & 7826 & 06782600 & $\begin{array}{l}\text { South Branch Mud Creek tributary near Broken Bow, } \\
\text { Nebraska }\end{array}$ & 412556 & 994208 & 0.40 & $\begin{array}{l}0.41 \\
0.41\end{array}$ & $\begin{array}{l}4.45 \\
18.3\end{array}$ & $\begin{array}{l}21.9 \\
23.6\end{array}$ & $\begin{array}{l}1.59 \\
3.64\end{array}$ & $\begin{array}{r}2.35 \\
22.50\end{array}$ & $\begin{array}{l}0.18 \\
1.57\end{array}$ & $\begin{array}{l}2.46 \\
1.08\end{array}$ & $\begin{array}{l}6.2 \\
3.75\end{array}$ \\
\hline $\mathbb{D}_{0}^{\infty}$ & 7827 & 06782700 & South Branch Mud Creek at Broken Bow, Nebraska & 412407 & 993851 & 9.87 & $\begin{array}{c}94.8 \\
9.87\end{array}$ & $\begin{array}{l}8.88 \\
8.25\end{array}$ & $\begin{array}{l}97.4 \\
23.5\end{array}$ & $\begin{array}{l}5.64 \\
5.13\end{array}$ & $\begin{array}{r}2.35 \\
23.04\end{array}$ & $\begin{array}{l}0.17 \\
1.95\end{array}$ & $\begin{array}{l}2.63 \\
0.241\end{array}$ & $\begin{array}{c}11.7 \\
4.43\end{array}$ \\
\hline $\begin{array}{l}\frac{\bar{\lambda}}{\hat{\lambda}} \\
\frac{\pi}{0}\end{array}$ & 7828 & 06782800 & North Branch Mud Creek at Broken Bow, Nebraska & 412435 & 993944 & 15.5 & $\begin{array}{l}15.8 \\
10.8\end{array}$ & $\begin{array}{c}2.77 \\
12.3\end{array}$ & $\begin{array}{c}109 \\
41.0\end{array}$ & $\begin{array}{l}2.24 \\
1.06\end{array}$ & $\begin{array}{r}2.35 \\
22.58\end{array}$ & $\begin{array}{l}0.20 \\
0.76\end{array}$ & $\begin{array}{l}0.370 \\
0.378\end{array}$ & $\begin{array}{c}10.4 \\
1.81\end{array}$ \\
\hline 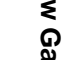 & 7829 & 06782900 & Mud Creek tributary near Broken Bow, Nebraska & 412231 & $9938 \quad 16$ & 5.90 & $\begin{array}{l}5.93 \\
5.93\end{array}$ & 2.29 & $\begin{array}{c}155 \\
66.0\end{array}$ & $\begin{array}{l}1.63 \\
1.11\end{array}$ & $\begin{array}{r}2.43 \\
22.57\end{array}$ & $\begin{array}{l}0.20 \\
0.76\end{array}$ & $\begin{array}{l}0.506 \\
0.427\end{array}$ & $\begin{array}{c}25.6 \\
1.66\end{array}$ \\
\hline 瓷 & 7835 & 06783500 & Mud Creek near Sweetwater, Nebraska & $4102 \quad 14$ & 985934 & 707 & $\begin{array}{l}711 \\
655\end{array}$ & $\begin{array}{l}4.69 \\
4.82\end{array}$ & $\begin{array}{c}146 \\
7.8\end{array}$ & $\begin{array}{l}2.28 \\
1.31\end{array}$ & $\begin{array}{r}2.43 \\
23.71\end{array}$ & $\begin{array}{l}0.20 \\
0.79\end{array}$ & $\begin{array}{l}0.508 \\
0.054\end{array}$ & $\begin{array}{c}18.6 \\
1.81\end{array}$ \\
\hline$\stackrel{\$}{\$}$ & 7840 & 06784000 & South Loup River at St. Michael, Nebraska & 410153 & 984424 & 2,320 & $\begin{array}{l}2,320 \\
1,590\end{array}$ & $\begin{array}{l}8.33 \\
2.98\end{array}$ & $\begin{array}{c}172 \\
5.9\end{array}$ & $\begin{array}{l}3.52 \\
1.31\end{array}$ & $\begin{array}{r}2.40 \\
23.04\end{array}$ & $\begin{array}{l}0.17 \\
1.83\end{array}$ & $\begin{array}{l}0.463 \\
0.035\end{array}$ & $\begin{array}{c}18.3 \\
4.28\end{array}$ \\
\hline$\stackrel{\bar{\lambda}}{x}$ & 7847 & 06784700 & Turkey Creek near Farwell, Nebraska & $41 \quad 13 \quad 14$ & 984045 & 27.2 & $\begin{array}{l}27.3 \\
27.3\end{array}$ & $\begin{array}{l}5.68 \\
7.12\end{array}$ & $\begin{array}{c}122 \\
15.8\end{array}$ & $\begin{array}{l}1.93 \\
1.68\end{array}$ & $\begin{array}{r}2.53 \\
24.66\end{array}$ & $\begin{array}{l}0.20 \\
0.61\end{array}$ & $\begin{array}{l}1.03 \\
0.130\end{array}$ & $\begin{array}{c}13.4 \\
1.33\end{array}$ \\
\hline & 7848 & 06784800 & Turkey Creek near Dannebrog, Nebraska & 410923 & 983321 & 66.2 & $\begin{array}{l}65.7 \\
65.7\end{array}$ & $\begin{array}{l}5.96 \\
6.18\end{array}$ & $\begin{array}{l}85.1 \\
12.4\end{array}$ & $\begin{array}{l}1.89 \\
1.68\end{array}$ & $\begin{array}{r}2.54 \\
24.36\end{array}$ & $\begin{array}{l}0.20 \\
0.61\end{array}$ & $\begin{array}{l}0.928 \\
0.145\end{array}$ & $\begin{array}{c}12.6 \\
1.32\end{array}$ \\
\hline & 7850 & 06785000 & Middle Loup River at St. Paul, Nebraska & $41 \quad 1154$ & 982650 & 8,090 & $\begin{array}{l}8,080 \\
3,130\end{array}$ & $\begin{array}{l}8.58 \\
2.75\end{array}$ & $\begin{array}{c}187 \\
6.3\end{array}$ & $\begin{array}{l}4.13 \\
1.28\end{array}$ & $\begin{array}{r}2.32 \\
21.74\end{array}$ & $\begin{array}{l}0.12 \\
3.87\end{array}$ & $\begin{array}{l}0.405 \\
0.034\end{array}$ & $\begin{array}{c}20.6 \\
8.74\end{array}$ \\
\hline & 7860 & 06786000 & North Loup River at Taylor, Nebraska & 414636 & 992245 & 2,350 & $\begin{array}{r}2,350 \\
186\end{array}$ & $\begin{array}{l}91.6 \\
3.66\end{array}$ & $\begin{array}{c}125 \\
9.1\end{array}$ & $\begin{array}{l}9.82 \\
2.07\end{array}$ & $\begin{array}{r}2.29 \\
21.70\end{array}$ & $\begin{array}{l}0.08 \\
5.59\end{array}$ & $\begin{array}{l}0.237 \\
0.073\end{array}$ & $\begin{array}{l}23.4 \\
12.62\end{array}$ \\
\hline & 7870 & 06787000 & Calamus River near Harrop, Nebraska & 415648 & $\begin{array}{lll}99 & 23 & 09\end{array}$ & 693 & $\begin{array}{l}693 \\
70.0\end{array}$ & $\begin{array}{c}47.6 \\
3.22\end{array}$ & $\begin{array}{r}88.6 \\
9.3\end{array}$ & $\begin{array}{l}7.72 \\
1.50\end{array}$ & $\begin{array}{r}2.36 \\
24.14\end{array}$ & $\begin{array}{l}0.08 \\
5.68\end{array}$ & $\begin{array}{l}0.114 \\
0.104\end{array}$ & $\begin{array}{l}25.5 \\
12.81\end{array}$ \\
\hline & 7875 & 06787500 & Calamus River near Burwell, Nebraska & 414834 & $99 \quad 1055$ & 994 & $\begin{array}{l}994 \\
100\end{array}$ & $\begin{array}{c}46.2 \\
2.90\end{array}$ & $\begin{array}{r}98.9 \\
7.9\end{array}$ & $\begin{array}{l}8.13 \\
1.45\end{array}$ & $\begin{array}{r}2.39 \\
23.80\end{array}$ & $\begin{array}{l}0.08 \\
5.71\end{array}$ & $\begin{array}{l}0.120 \\
0.080\end{array}$ & $\begin{array}{l}25.1 \\
12.81\end{array}$ \\
\hline
\end{tabular}


Table B1. Selected drainage-basin characteristics for streamflow-gaging stations in Nebraska and for selected out-of-state stations--Continued

\begin{tabular}{|c|c|c|c|c|c|c|c|c|c|c|c|c|c|}
\hline \multirow[b]{2}{*}{$\underset{\text { num- }}{\text { Map }}$} & \multirow[b]{2}{*}{$\begin{array}{c}\text { Station } \\
\text { number }\end{array}$} & \multirow[b]{2}{*}{ Station name-remarks } & \multirow[b]{2}{*}{$\begin{array}{c}\text { Latitude } \\
\left({ }^{\circ}, "\right)\end{array}$} & \multirow[b]{2}{*}{$\begin{array}{c}\text { Longitude } \\
\left(0,{ }^{\circ},{ }^{\prime}\right)\end{array}$} & \multirow{2}{*}{$\begin{array}{c}\text { Published } \\
\text { total } \\
\text { drainage } \\
\text { area } \\
\left(\mathrm{mi}^{2}\right)\end{array}$} & \multicolumn{8}{|c|}{ Drainage-basin characteristics } \\
\hline & & & & & & $\begin{array}{l}\text { TDA } \\
\text { CDA }\end{array}$ & $\begin{array}{l}\text { SF } \\
\text { RR }\end{array}$ & $\begin{array}{l}\text { BS } \\
\text { MCS }\end{array}$ & $\begin{array}{l}\text { CR } \\
\text { SD }\end{array}$ & $\begin{array}{l}\text { TTP } \\
\text { MAP }\end{array}$ & $\begin{array}{l}\text { AWC } \\
\text { PLP }\end{array}$ & $\begin{array}{l}\text { DF } \\
\text { SR }\end{array}$ & $\begin{array}{l}\text { MSS } \\
\text { P60 }\end{array}$ \\
\hline 7885 & 06788500 & North Loup River at Ord, Nebraska & 413626 & 985516 & 3,760 & $\begin{array}{r}3,760 \\
700\end{array}$ & $\begin{array}{l}42.6 \\
3.36\end{array}$ & $\begin{array}{l}122 \\
8.0\end{array}$ & $\begin{array}{l}6.28 \\
1.41\end{array}$ & $\begin{array}{r}2.33 \\
22.38\end{array}$ & $\begin{array}{l}0.09 \\
5.19\end{array}$ & $\begin{array}{l}0.320 \\
0.066\end{array}$ & $\begin{array}{l}23.0 \\
11.74\end{array}$ \\
\hline $7889 \mathrm{a}$ & 06788988 & Mira Creek near North Loup, Nebraska & 413009 & $9847 \quad 47$ & 65.8 & $\begin{array}{l}65.8 \\
65.8\end{array}$ & $\begin{array}{l}1.21 \\
9.10\end{array}$ & $\begin{array}{c}121 \\
9.2\end{array}$ & $\begin{array}{l}1.61 \\
1.17\end{array}$ & $\begin{array}{r}2.45 \\
24.12\end{array}$ & $\begin{array}{l}0.20 \\
0.60\end{array}$ & $\begin{array}{l}0.517 \\
0.076\end{array}$ & $\begin{array}{l}11.6 \\
1.37\end{array}$ \\
\hline 7890 & 06789000 & North Loup River at Scotia, Nebraska & 412730 & 984239 & 4,100 & $\begin{array}{r}3,970 \\
910\end{array}$ & $\begin{array}{c}39.0 \\
3.39\end{array}$ & $\begin{array}{r}131 \\
8.2\end{array}$ & $\begin{array}{l}5.80 \\
1.36\end{array}$ & $\begin{array}{r}2.34 \\
22.47\end{array}$ & $\begin{array}{l}0.10 \\
4.96\end{array}$ & $\begin{array}{l}0.336 \\
0.062\end{array}$ & $\begin{array}{l}22.5 \\
11.23\end{array}$ \\
\hline 7891 & 06789100 & Davis Creek tributary near North Loup, Nebraska & 412421 & 985407 & 2.29 & $\begin{array}{l}2.31 \\
2.31\end{array}$ & $\begin{array}{c}1.02 \\
19.8\end{array}$ & $\begin{array}{c}112 \\
24.3\end{array}$ & $\begin{array}{l}1.32 \\
1.11\end{array}$ & $\begin{array}{r}2.45 \\
24.72\end{array}$ & $\begin{array}{l}0.20 \\
0.60\end{array}$ & $\begin{array}{l}0.865 \\
0.216\end{array}$ & $\begin{array}{c}26.8 \\
1.30\end{array}$ \\
\hline 7892 & 06789200 & Davis Creek tributary \#2 near North Loup, Nebraska & 412545 & 985415 & 6.79 & $\begin{array}{l}6.79 \\
6.79\end{array}$ & $\begin{array}{l}1.93 \\
15.2\end{array}$ & $\begin{array}{l}113 \\
23.5\end{array}$ & $\begin{array}{l}1.38 \\
1.40\end{array}$ & $\begin{array}{r}2.45 \\
24.72\end{array}$ & $\begin{array}{l}0.20 \\
0.60\end{array}$ & $\begin{array}{l}0.737 \\
0.209\end{array}$ & $\begin{array}{c}22.9 \\
1.32\end{array}$ \\
\hline 7893 & 06789300 & Davis Creek near North Loup, Nebraska & 412444 & 985200 & 21.1 & $\begin{array}{l}21.1 \\
21.1\end{array}$ & $\begin{array}{l}1.81 \\
9.84\end{array}$ & $\begin{array}{c}135 \\
18.9\end{array}$ & $\begin{array}{l}1.43 \\
1.35\end{array}$ & $\begin{array}{r}2.45 \\
24.72\end{array}$ & $\begin{array}{l}0.20 \\
0.60\end{array}$ & $\begin{array}{l}0.616 \\
0.140\end{array}$ & $\begin{array}{c}23.6 \\
1.32\end{array}$ \\
\hline 7894 & 06789400 & Davis Creek southwest of North Loup, Nebraska & 412432 & 984832 & 31.2 & $\begin{array}{l}31.3 \\
31.3\end{array}$ & $\begin{array}{l}2.03 \\
9.58\end{array}$ & $\begin{array}{c}161 \\
19.4\end{array}$ & $\begin{array}{l}1.54 \\
1.25\end{array}$ & $\begin{array}{r}2.45 \\
24.64\end{array}$ & $\begin{array}{l}0.20 \\
0.60\end{array}$ & $\begin{array}{l}0.543 \\
0.120\end{array}$ & $\begin{array}{c}22.5 \\
1.32\end{array}$ \\
\hline 7895 & 06789500 & Davis Creek near Cotesfield, Nebraska & 412350 & 984100 & 94.0 & $\begin{array}{l}81.5 \\
81.5\end{array}$ & $\begin{array}{l}2.77 \\
2.31\end{array}$ & $\begin{array}{r}30.0 \\
5.3\end{array}$ & $\begin{array}{l}1.73 \\
1.13\end{array}$ & $\begin{array}{r}2.48 \\
24.50\end{array}$ & $\begin{array}{l}0.20 \\
0.60\end{array}$ & $\begin{array}{l}0.419 \\
0.176\end{array}$ & $\begin{array}{c}23.2 \\
1.32\end{array}$ \\
\hline 7905 & 06790500 & North Loup River near St. Paul, Nebraska & $41 \quad 1534$ & 982650 & 4,290 & $\begin{array}{l}4,300 \\
1,240\end{array}$ & $\begin{array}{c}23.7 \\
3.33\end{array}$ & $\begin{array}{r}139 \\
7.5\end{array}$ & $\begin{array}{l}5.37 \\
1.32\end{array}$ & $\begin{array}{r}2.35 \\
22.63\end{array}$ & $\begin{array}{l}0.10 \\
4.65\end{array}$ & $\begin{array}{l}0.369 \\
0.054\end{array}$ & $\begin{array}{l}21.9 \\
10.54\end{array}$ \\
\hline 7906 & 06790600 & East Branch Spring Creek tributary near Wolbach, Nebraska & 412728 & $98 \quad 2544$ & 1.52 & $\begin{array}{l}1.50 \\
1.50\end{array}$ & $\begin{array}{c}4.56 \\
13.5\end{array}$ & $\begin{array}{l}84.4 \\
21.5\end{array}$ & $\begin{array}{l}1.73 \\
1.76\end{array}$ & $\begin{array}{r}2.55 \\
25.61\end{array}$ & $\begin{array}{l}0.20 \\
0.60\end{array}$ & $\begin{array}{l}1.33 \\
0.255\end{array}$ & $\begin{array}{c}16.2 \\
1.30\end{array}$ \\
\hline 7907 & 06790700 & West Branch Spring Creek at Brayton, Nebraska & 412727 & 982838 & 19.5 & $\begin{array}{l}19.5 \\
19.5\end{array}$ & $\begin{array}{l}4.56 \\
9.75\end{array}$ & $\begin{array}{c}138 \\
17.9\end{array}$ & $\begin{array}{l}1.72 \\
1.38\end{array}$ & $\begin{array}{r}2.55 \\
25.61\end{array}$ & $\begin{array}{l}0.20 \\
0.61\end{array}$ & $\begin{array}{l}0.770 \\
0.130\end{array}$ & $\begin{array}{c}11.5 \\
1.35\end{array}$ \\
\hline 7908 & 06790800 & West Branch Spring Creek near Wolbach, Nebraska & 412600 & 982604 & 36.9 & $\begin{array}{l}36.9 \\
36.9\end{array}$ & $\begin{array}{l}3.87 \\
8.08\end{array}$ & $\begin{array}{l}121 \\
17.1\end{array}$ & $\begin{array}{l}1.62 \\
1.42\end{array}$ & $\begin{array}{r}2.55 \\
25.61\end{array}$ & $\begin{array}{l}0.20 \\
0.61\end{array}$ & $\begin{array}{l}0.758 \\
0.142\end{array}$ & $\begin{array}{c}12.1 \\
1.34\end{array}$ \\
\hline 7909 & 06790900 & Mary's Creek at Wolbach, Nebraska & 412400 & 982339 & 7.63 & $\begin{array}{l}7.57 \\
7.57\end{array}$ & $\underset{14.5}{2.27}$ & $\begin{array}{c}165 \\
22.4\end{array}$ & $\begin{array}{l}1.53 \\
1.40\end{array}$ & $\begin{array}{r}2.55 \\
25.61\end{array}$ & $\begin{array}{l}0.20 \\
0.60\end{array}$ & $\begin{array}{l}0.793 \\
0.136\end{array}$ & $\begin{array}{c}15.9 \\
1.30\end{array}$ \\
\hline 7911 & 06791100 & Spring Creek near Cushing, Nebraska & $41 \quad 1708$ & $98 \quad 2242$ & 184 & $\begin{array}{l}188 \\
188\end{array}$ & $\begin{array}{l}5.06 \\
5.99\end{array}$ & $\begin{array}{c}165 \\
9.6\end{array}$ & $\begin{array}{l}1.74 \\
1.16\end{array}$ & $\begin{array}{r}2.55 \\
25.37\end{array}$ & $\begin{array}{l}0.18 \\
1.62\end{array}$ & $\begin{array}{l}0.464 \\
0.058\end{array}$ & $\begin{array}{c}11.9 \\
3.60\end{array}$ \\
\hline 7915 & 06791500 & Cedar River near Spalding, Nebraska & 414241 & 982648 & 762 & $\begin{array}{c}752 \\
50.0\end{array}$ & $\begin{array}{c}56.4 \\
3.06\end{array}$ & $\begin{array}{r}91.2 \\
7.2\end{array}$ & $\begin{array}{l}8.20 \\
3.20\end{array}$ & $\begin{array}{r}2.48 \\
23.43\end{array}$ & $\begin{array}{l}0.08 \\
5.57\end{array}$ & $\begin{array}{l}0.600 \\
0.079\end{array}$ & $\begin{array}{l}17.6 \\
12.48\end{array}$ \\
\hline 7920 & 06792000 & Cedar River near Fullerton, Nebraska & 412345 & $98 \quad 00 \quad 14$ & 1,220 & $\begin{array}{r}1,220 \\
480\end{array}$ & $\begin{array}{c}13.6 \\
3.09\end{array}$ & $\begin{array}{c}111 \\
6.3\end{array}$ & $\begin{array}{l}3.77 \\
1.09\end{array}$ & $\begin{array}{r}2.52 \\
24.51\end{array}$ & $\begin{array}{l}0.12 \\
3.94\end{array}$ & $\begin{array}{l}0.310 \\
0.056\end{array}$ & $\begin{array}{c}15.0 \\
8.92\end{array}$ \\
\hline 7935 & 06793500 & Beaver Creek at Loretto, Nebraska & 414550 & 980450 & 311 & $\begin{array}{l}372 \\
209\end{array}$ & $\begin{array}{l}3.91 \\
3.05\end{array}$ & $\begin{array}{r}61.6 \\
6.4\end{array}$ & $\begin{array}{l}2.88 \\
0.280\end{array}$ & $\begin{array}{r}2.54 \\
24.71\end{array}$ & $\begin{array}{l}0.09 \\
4.74\end{array}$ & $\begin{array}{l}0.033 \\
0.103\end{array}$ & $\begin{array}{l}11.9 \\
11.21\end{array}$ \\
\hline $7939 \mathrm{a}$ & 06793995 & Skeedee Creek tributary near Genoa, Nebraska & 412946 & 975223 & 0.59 & $\begin{array}{l}0.59 \\
0.59\end{array}$ & $\begin{array}{c}3.10 \\
13.6\end{array}$ & $\begin{array}{l}43.3 \\
26.2\end{array}$ & $\begin{array}{l}1.52 \\
2.29\end{array}$ & $\begin{array}{r}2.65 \\
27.83\end{array}$ & $\begin{array}{l}0.18 \\
0.27\end{array}$ & $\begin{array}{l}1.71 \\
0.604\end{array}$ & $\begin{array}{l}3.9 \\
0.80\end{array}$ \\
\hline 7940 & 06794000 & Beaver Creek at Genoa, Nebraska & 412631 & $9744 \quad 10$ & 677 & $\begin{array}{l}677 \\
429\end{array}$ & $\begin{array}{l}7.32 \\
3.11\end{array}$ & $\begin{array}{l}108 \\
5.6\end{array}$ & $\begin{array}{l}2.95 \\
0.808\end{array}$ & $\begin{array}{r}2.59 \\
26.09\end{array}$ & $\begin{array}{l}0.14 \\
2.98\end{array}$ & $\begin{array}{l}0.207 \\
0.051\end{array}$ & $\begin{array}{c}10.4 \\
7.03\end{array}$ \\
\hline
\end{tabular}


Table B1. Selected drainage-basin characteristics for streamflow-gaging stations in Nebraska and for selected out-of-state stations--Continued

\begin{tabular}{|c|c|c|c|c|c|c|c|c|c|c|c|c|c|}
\hline $\begin{array}{c}\text { Map } \\
\text { num- } \\
\text { ber }\end{array}$ & $\begin{array}{l}\text { Station } \\
\text { number }\end{array}$ & Station name-remarks & $\begin{array}{c}\text { Latitude } \\
(0, \%)\end{array}$ & $\begin{array}{c}\text { Longitude } \\
(0, ")\end{array}$ & $\begin{array}{c}\text { Published } \\
\text { total } \\
\text { drainage } \\
\text { area } \\
\left(\mathrm{mi}^{2}\right)\end{array}$ & $\begin{array}{l}\text { TDA } \\
\text { CDA }\end{array}$ & $\begin{array}{l}\mathrm{SF} \\
\mathrm{RR}\end{array}$ & $\begin{array}{l}\text { BS } \\
\text { MCS }\end{array}$ & $\begin{array}{l}\text { CR } \\
\text { SD }\end{array}$ & $\begin{array}{l}\text { TTP } \\
\text { MAP }\end{array}$ & $\begin{array}{l}\text { AWC } \\
\text { PLP }\end{array}$ & $\begin{array}{l}\mathrm{DF} \\
\mathrm{SR}\end{array}$ & $\begin{array}{l}\text { MSS } \\
\text { P60 }\end{array}$ \\
\hline 7945 & 06794500 & Loup River at Columbus, Nebraska & 412505 & 972145 & 15,200 & $\begin{array}{r}15,200 \\
6,230\end{array}$ & $\begin{array}{l}4.12 \\
2.82\end{array}$ & $\begin{array}{l}177 \\
\quad 7.4\end{array}$ & $\begin{array}{l}3.55 \\
1.18\end{array}$ & $\begin{array}{r}2.37 \\
22.68\end{array}$ & $\begin{array}{l}0.12 \\
3.93\end{array}$ & $\begin{array}{l}0.348 \\
0.042\end{array}$ & $\begin{array}{c}19.4 \\
8.94\end{array}$ \\
\hline 7947a & 06794710 & Bone Creek near David City, Nebraska & 411641 & 970251 & 8.75 & $\begin{array}{l}8.75 \\
8.75\end{array}$ & $\begin{array}{l}1.18 \\
12.7\end{array}$ & $\begin{array}{l}149 \\
31.1\end{array}$ & $\begin{array}{l}1.33 \\
0.919\end{array}$ & $\begin{array}{r}2.85 \\
29.83\end{array}$ & $\begin{array}{l}0.19 \\
0.23\end{array}$ & $\begin{array}{l}0.229 \\
0.208\end{array}$ & $\begin{array}{l}7.4 \\
1.02\end{array}$ \\
\hline 7950 & 06795000 & Shell Creek at Newman Grove, Nebraska & 414430 & 974500 & 122 & $\begin{array}{l}121 \\
121\end{array}$ & $\begin{array}{l}2.84 \\
6.26\end{array}$ & $\begin{array}{c}153 \\
13.3\end{array}$ & $\begin{array}{l}1.60 \\
0.862\end{array}$ & $\begin{array}{r}2.65 \\
27.27\end{array}$ & $\begin{array}{l}0.20 \\
0.55\end{array}$ & $\begin{array}{l}0.322 \\
0.087\end{array}$ & $\begin{array}{l}8.6 \\
1.29\end{array}$ \\
\hline 7955 & 06795500 & Shell Creek near Columbus, Nebraska & 413132 & 971654 & 294 & $\begin{array}{l}294 \\
294\end{array}$ & $\begin{array}{l}10.4 \\
4.49\end{array}$ & $\begin{array}{l}150 \\
6.5\end{array}$ & $\begin{array}{l}2.28 \\
0.913\end{array}$ & $\begin{array}{r}2.69 \\
27.36\end{array}$ & $\begin{array}{l}0.20 \\
0.53\end{array}$ & $\begin{array}{l}0.316 \\
0.043\end{array}$ & $\begin{array}{l}7.7 \\
1.26\end{array}$ \\
\hline 7969b & 06796978 & Holt Creek near Emmet, Nebraska & 422519 & 985146 & -- & $\begin{array}{l}289 \\
289\end{array}$ & $\begin{array}{l}4.75 \\
3.86\end{array}$ & $\begin{array}{l}76.0 \\
11.6\end{array}$ & $\begin{array}{l}2.65 \\
0.195\end{array}$ & $\begin{array}{r}2.42 \\
23.41\end{array}$ & $\begin{array}{l}0.08 \\
5.37\end{array}$ & $\begin{array}{l}0.010 \\
0.153\end{array}$ & $\begin{array}{l}18.0 \\
12.60\end{array}$ \\
\hline 7975 & 06797500 & Elkhorn River at Ewing, Nebraska & 421603 & 982010 & 1,400 & $\begin{array}{r}1,420 \\
740\end{array}$ & $\begin{array}{l}6.25 \\
3.19\end{array}$ & $\begin{array}{r}53.6 \\
5.5\end{array}$ & $\begin{array}{l}2.73 \\
0.481\end{array}$ & $\begin{array}{r}2.44 \\
23.28\end{array}$ & $\begin{array}{l}0.08 \\
5.00\end{array}$ & $\begin{array}{l}0.042 \\
0.103\end{array}$ & $\begin{array}{l}11.1 \\
12.44\end{array}$ \\
\hline 7980 & 06798000 & South Fork Elkhorn River at Ewing, Nebraska & 421429 & 982353 & 314 & $\begin{array}{l}292 \\
204\end{array}$ & $\begin{array}{l}6.48 \\
4.51\end{array}$ & $\begin{array}{r}51.8 \\
8.6\end{array}$ & $\begin{array}{l}2.731 \\
0.397\end{array}$ & $\begin{array}{r}2.46 \\
22.49\end{array}$ & $\begin{array}{l}0.07 \\
5.14\end{array}$ & $\begin{array}{l}0.034 \\
0.166\end{array}$ & $\begin{array}{l}8.4 \\
12.55\end{array}$ \\
\hline 7983 & 06798300 & Clearwater Creek near Clearwater, Nebraska & 420820 & 98129 & 210 & $\begin{array}{l}182 \\
150\end{array}$ & $\begin{array}{l}2.46 \\
3.60\end{array}$ & $\begin{array}{r}41.0 \\
8.3\end{array}$ & $\begin{array}{l}1.89 \\
0.381\end{array}$ & $\begin{array}{r}2.55 \\
24.19\end{array}$ & $\begin{array}{l}0.09 \\
4.58\end{array}$ & $\begin{array}{l}0.080 \\
0.203\end{array}$ & $\begin{array}{c}7.6 \\
11.33\end{array}$ \\
\hline 7985 & 06798500 & Elkhorn River at Neligh, Nebraska & 420719 & 980140 & 2200 & $\begin{array}{l}2290 \\
1200\end{array}$ & $\begin{array}{l}6.06 \\
3.03\end{array}$ & $\begin{array}{r}54.9 \\
5.8\end{array}$ & $\begin{array}{l}2.63 \\
0.521\end{array}$ & $\begin{array}{r}2.47 \\
23.27\end{array}$ & $\begin{array}{l}0.08 \\
4.87\end{array}$ & $\begin{array}{l}0.058 \\
0.106\end{array}$ & $\begin{array}{c}9.9 \\
12.10\end{array}$ \\
\hline 7990 & 06799000 & Elkhorn River at Norfolk, Nebraska & 420014 & 972530 & 2,790 & $\begin{array}{l}2,860 \\
1,790\end{array}$ & $\begin{array}{l}7.13 \\
2.75\end{array}$ & $\begin{array}{r}70.8 \\
5.2\end{array}$ & $\begin{array}{l}2.87 \\
0.508\end{array}$ & $\begin{array}{r}2.50 \\
23.73\end{array}$ & $\begin{array}{l}0.10 \\
4.26\end{array}$ & $\begin{array}{l}0.075 \\
0.074\end{array}$ & $\begin{array}{c}9.5 \\
10.61\end{array}$ \\
\hline 7990b & 06799080 & $\begin{array}{l}\text { Willow Creek near Foster, Nebraska-considerable non- } \\
\text { contributing drainage area apparent on 1:24,000-scale } \\
\text { topographic maps }\end{array}$ & 421037 & 974001 & 137 & $\begin{array}{l}139 \\
\underline{139} \\
\end{array}$ & $\frac{3.84}{4.79}$ & $\begin{array}{r}58.9 \\
8.9\end{array}$ & $\frac{1.85}{0.187}$ & $\begin{array}{r}2.62 \\
24.04\end{array}$ & $\begin{array}{l}0.11 \\
3.71\end{array}$ & $\frac{0.007}{0.151}$ & $\begin{array}{l}6.5 \\
9.54\end{array}$ \\
\hline 7991 & 06799100 & North Fork Elkhorn River near Pierce, Nebraska & 421044 & 972903 & 700 & $\begin{array}{l}701 \\
670\end{array}$ & $\begin{array}{l}1.18 \\
2.70\end{array}$ & $\begin{array}{r}79.3 \\
6.0\end{array}$ & $\begin{array}{l}1.93 \\
0.386\end{array}$ & $\begin{array}{r}2.65 \\
24.83\end{array}$ & $\begin{array}{l}0.15 \\
2.20\end{array}$ & $\begin{array}{l}0.052 \\
0.076\end{array}$ & $\begin{array}{l}6.2 \\
6.09\end{array}$ \\
\hline 7991b & 06799190 & South Fork Union Creek tributary near Cornlea, Nebraska & 414200 & 973422 & 6.54 & $\begin{array}{l}6.51 \\
6.51\end{array}$ & $\begin{array}{l}0.69 \\
4.28\end{array}$ & $\begin{array}{r}48.8 \\
6.5\end{array}$ & $\begin{array}{l}1.27 \\
1.15\end{array}$ & $\begin{array}{r}2.75 \\
25.90\end{array}$ & $\begin{array}{l}0.18 \\
0.29\end{array}$ & $\begin{array}{l}0.768 \\
0.133\end{array}$ & $\begin{array}{l}4.3 \\
0.84\end{array}$ \\
\hline 7992a & 06799230 & Union Creek at Madison, Nebraska & 414951 & 972718 & 174 & $\begin{array}{l}174 \\
174\end{array}$ & $\begin{array}{l}1.25 \\
4.22\end{array}$ & $\begin{array}{r}71.7 \\
8.1\end{array}$ & $\begin{array}{l}1.61 \\
0.416\end{array}$ & $\begin{array}{r}2.71 \\
25.88\end{array}$ & $\begin{array}{l}0.19 \\
0.57\end{array}$ & $\begin{array}{l}0.063 \\
0.113\end{array}$ & $\begin{array}{l}7.6 \\
1.37\end{array}$ \\
\hline 7993a & 06799350 & Elkhorn River at West Point, Nebraska & 415011 & 964332 & 5,100 & $\begin{array}{l}4,680 \\
4,100\end{array}$ & $\begin{array}{l}6.32 \\
2.38\end{array}$ & $\begin{array}{r}91.2 \\
4.7\end{array}$ & $\begin{array}{l}2.56 \\
0.453\end{array}$ & $\begin{array}{r}2.59 \\
24.55\end{array}$ & $\begin{array}{l}0.12 \\
3.21\end{array}$ & $\begin{array}{l}0.080 \\
0.052\end{array}$ & $\begin{array}{l}8.4 \\
8.14\end{array}$ \\
\hline 7993b & 06799385 & Pebble Creek at Scribner, Nebraska & 413934 & 964059 & 204 & $\begin{array}{l}206 \\
206\end{array}$ & $\begin{array}{l}3.10 \\
6.06\end{array}$ & $\begin{array}{l}108.8 \\
12.8\end{array}$ & $\begin{array}{l}1.42 \\
0.834\end{array}$ & $\begin{array}{r}2.85 \\
29.26\end{array}$ & $\begin{array}{l}0.19 \\
0.39\end{array}$ & $\begin{array}{l}0.219 \\
0.118\end{array}$ & $\begin{array}{l}6.8 \\
1.18\end{array}$ \\
\hline 7994a & 06799423 & North Logan Creek near Laurel, Nebraska & 422800 & 970255 & 25.3 & $\begin{array}{l}25.4 \\
25.4\end{array}$ & $\begin{array}{l}3.78 \\
6.37\end{array}$ & $\begin{array}{r}86.1 \\
7.9\end{array}$ & $\begin{array}{l}1.59 \\
0.569\end{array}$ & $\begin{array}{r}2.75 \\
25.73\end{array}$ & $\begin{array}{l}0.19 \\
0.68\end{array}$ & $\begin{array}{l}0.079 \\
0.092\end{array}$ & $\begin{array}{l}7.2 \\
1.87\end{array}$ \\
\hline 7994b & 06799450 & Logan Creek at Pender, Nebraska & 420639 & 964159 & 731 & $\begin{array}{l}736 \\
736\end{array}$ & $\begin{array}{l}2.82 \\
3.42\end{array}$ & $\begin{array}{l}148 \\
6.5\end{array}$ & $\begin{array}{l}1.69 \\
0.593\end{array}$ & $\begin{array}{r}2.77 \\
26.75\end{array}$ & $\begin{array}{l}0.19 \\
0.56\end{array}$ & $\begin{array}{l}0.106 \\
0.044\end{array}$ & $\begin{array}{l}7.5 \\
1.47\end{array}$ \\
\hline 7995 & 06799500 & Logan Creek near Uehling, Nebraska & 414250 & 963115 & 1,030 & $\begin{array}{l}1,020 \\
1,020\end{array}$ & $\begin{array}{r}5.71 \\
2.79\end{array}$ & $\begin{array}{l}146 \\
5.2\end{array}$ & $\begin{array}{l}2.12 \\
0.612\end{array}$ & $\begin{array}{r}2.80 \\
27.16\end{array}$ & $\begin{array}{l}0.19 \\
0.51\end{array}$ & $\begin{array}{l}0.107 \\
0.035\end{array}$ & $\begin{array}{l}7.0 \\
1.37\end{array}$ \\
\hline
\end{tabular}


Table B1. Selected drainage-basin characteristics for streamflow-gaging stations in Nebraska and for selected out-of-state stations--Continued

\begin{tabular}{|c|c|c|c|c|c|c|c|c|c|c|c|c|c|}
\hline \multirow[b]{2}{*}{$\begin{array}{c}\text { Map } \\
\text { num- } \\
\text { ber }\end{array}$} & \multirow[b]{2}{*}{$\begin{array}{c}\text { Station } \\
\text { number }\end{array}$} & \multirow[b]{2}{*}{ Station name-remarks } & \multirow[b]{2}{*}{$\begin{array}{c}\text { Latitude } \\
(0, \ldots)\end{array}$} & \multirow[b]{2}{*}{$\begin{array}{c}\text { Longitude } \\
\left(0,{ }^{\circ},{ }^{\prime}\right)\end{array}$} & \multirow{2}{*}{$\begin{array}{c}\text { Published } \\
\text { total } \\
\text { drainage } \\
\text { area } \\
\left(\mathrm{mi}^{2}\right)\end{array}$} & \multicolumn{8}{|c|}{ Drainage-basin characteristics } \\
\hline & & & & & & $\begin{array}{l}\text { TDA } \\
\text { CDA }\end{array}$ & $\begin{array}{l}\text { SF } \\
\text { RR }\end{array}$ & $\begin{array}{l}\text { BS } \\
\text { MCS }\end{array}$ & $\begin{array}{l}\text { CR } \\
\text { SD }\end{array}$ & $\begin{array}{l}\text { TTP } \\
\text { MAP }\end{array}$ & $\begin{array}{l}\text { AWC } \\
\text { PLP }\end{array}$ & $\begin{array}{l}\text { DF } \\
\text { SR }\end{array}$ & $\begin{array}{l}\text { MSS } \\
\text { P60 }\end{array}$ \\
\hline 7998a & 06799850 & Pond Creek near Schuyler, Nebraska & $4131 \quad 15$ & 970333 & 0.54 & $\begin{array}{l}0.52 \\
0.52\end{array}$ & $\begin{array}{l}1.13 \\
17.2\end{array}$ & $\begin{array}{r}69.9 \\
\underline{0.0} \\
\end{array}$ & $\begin{array}{l}1.19 \\
1.55\end{array}$ & $\begin{array}{r}2.85 \\
27.73\end{array}$ & $\begin{array}{l}0.20 \\
0.44\end{array}$ & $\begin{array}{l}1.91 \\
\underline{0.000}\end{array}$ & $\begin{array}{l}8.6 \\
1.26\end{array}$ \\
\hline 8000 & 06800000 & Maple Creek near Nickerson, Nebraska & 413245 & 963005 & 450 & $\begin{array}{l}369 \\
369\end{array}$ & $\begin{array}{l}6.65 \\
4.07\end{array}$ & $\begin{array}{c}156 \\
6.6\end{array}$ & $\begin{array}{l}2.02 \\
0.767\end{array}$ & $\begin{array}{r}2.82 \\
25.77\end{array}$ & $\begin{array}{l}0.20 \\
0.46\end{array}$ & $\begin{array}{l}0.201 \\
0.042\end{array}$ & $\begin{array}{l}7.7 \\
1.18\end{array}$ \\
\hline $8003 \mathrm{a}$ & 06800350 & Elkhorn River tributary near Nickerson, Nebraska & 413034 & 963306 & 6.53 & $\begin{array}{l}6.21 \\
6.21\end{array}$ & $\begin{array}{l}1.56 \\
6.26\end{array}$ & $\begin{array}{r}43.5 \\
9.9\end{array}$ & $\begin{array}{l}1.42 \\
0.637\end{array}$ & $\begin{array}{r}2.95 \\
30.42\end{array}$ & $\begin{array}{l}0.19 \\
0.21\end{array}$ & $\begin{array}{l}0.161 \\
0.229\end{array}$ & $\begin{array}{l}4.1 \\
1.21\end{array}$ \\
\hline 8005 & 06800500 & Elkhorn River at Waterloo, Nebraska & $41 \quad 1725$ & 961704 & 6,900 & $\begin{array}{l}6,950 \\
5,870\end{array}$ & $\begin{array}{l}6.59 \\
2.27\end{array}$ & $\begin{array}{c}105 \\
4.4\end{array}$ & $\begin{array}{l}2.57 \\
0.588\end{array}$ & $\begin{array}{r}2.67 \\
25.77\end{array}$ & $\begin{array}{l}0.15 \\
2.34\end{array}$ & $\begin{array}{l}0.117 \\
0.042\end{array}$ & $\begin{array}{l}7.8 \\
6.00\end{array}$ \\
\hline 8030 & 06803000 & Salt Creek at Roca, Nebraska & 403929 & 963954 & 167 & $\begin{array}{l}167 \\
167\end{array}$ & $\begin{array}{l}1.25 \\
4.05\end{array}$ & $\begin{array}{c}168 \\
10.4\end{array}$ & $\begin{array}{l}1.64 \\
0.779\end{array}$ & $\begin{array}{r}3.03 \\
30.22\end{array}$ & $\begin{array}{l}0.16 \\
0.15\end{array}$ & $\begin{array}{l}0.257 \\
0.062\end{array}$ & $\begin{array}{l}7.0 \\
0.44\end{array}$ \\
\hline 8035b & 06803510 & Little Salt Creek near Lincoln, Nebraska & 405335 & 964051 & 43.6 & $\begin{array}{l}43.6 \\
43.6\end{array}$ & $\begin{array}{l}4.12 \\
9.23\end{array}$ & $\begin{array}{c}110 \\
19.8\end{array}$ & $\begin{array}{l}1.67 \\
1.50\end{array}$ & $\begin{array}{r}2.95 \\
28.59\end{array}$ & $\begin{array}{l}0.18 \\
0.20\end{array}$ & $\begin{array}{l}0.643 \\
0.181\end{array}$ & $\begin{array}{c}10.6 \\
0.78\end{array}$ \\
\hline $8035 c$ & 06803520 & Stevens Creek near Lincoln, Nebraska & 405124 & 963541 & 47.8 & $\begin{array}{l}47.8 \\
47.8\end{array}$ & $\begin{array}{l}2.53 \\
8.90\end{array}$ & $\begin{array}{l}120 \\
17.9\end{array}$ & $\begin{array}{l}1.40 \\
0.812\end{array}$ & $\begin{array}{r}3.05 \\
31.01\end{array}$ & $\begin{array}{l}0.18 \\
0.22\end{array}$ & $\begin{array}{l}0.272 \\
0.149\end{array}$ & $\begin{array}{l}7.1 \\
0.80\end{array}$ \\
\hline 8035d & 06803530 & Rock Creek near Ceresco, Nebraska & 410056 & 963239 & 119 & $\begin{array}{l}120 \\
120\end{array}$ & $\begin{array}{l}2.87 \\
6.59\end{array}$ & $\begin{array}{c}106 \\
11.9\end{array}$ & $\begin{array}{l}1.57 \\
1.25\end{array}$ & $\begin{array}{r}2.95 \\
30.48\end{array}$ & $\begin{array}{l}0.19 \\
0.24\end{array}$ & $\begin{array}{l}0.502 \\
0.112\end{array}$ & $\begin{array}{l}8.3 \\
0.92\end{array}$ \\
\hline $8035 \mathrm{e}$ & 06803540 & Dee Creek near Alvo, Nebraska & 405452 & 962504 & 7.88 & $\begin{array}{l}7.90 \\
7.90\end{array}$ & $\begin{array}{c}2.30 \\
14.0\end{array}$ & $\begin{array}{c}109 \\
27.6\end{array}$ & $\begin{array}{l}1.34 \\
0.892\end{array}$ & $\begin{array}{r}3.05 \\
30.51\end{array}$ & $\begin{array}{l}0.19 \\
0.23\end{array}$ & $\begin{array}{l}0.380 \\
0.254\end{array}$ & $\begin{array}{l}8.0 \\
1.03\end{array}$ \\
\hline $8035 \mathrm{~g}$ & 06803570 & Dunlap Creek tributary near Weston, Nebraska & $41 \quad 1224$ & 964846 & 0.43 & $\begin{array}{l}0.42 \\
0.42\end{array}$ & $\begin{array}{l}2.35 \\
23.2\end{array}$ & $\begin{array}{c}142 \\
28.6\end{array}$ & $\begin{array}{l}1.35 \\
2.54\end{array}$ & $\begin{array}{r}2.95 \\
28.24\end{array}$ & $\begin{array}{l}0.17 \\
0.18\end{array}$ & $\begin{array}{l}2.38 \\
0.202\end{array}$ & $\begin{array}{c}12.8 \\
0.66\end{array}$ \\
\hline 8036 & 06803600 & North Fork Wahoo Creek near Prague, Nebraska & $41 \quad 1537$ & 964847 & 15.2 & $\begin{array}{l}15.4 \\
15.4\end{array}$ & $\begin{array}{l}1.87 \\
14.5\end{array}$ & $\begin{array}{c}191 \\
30.8\end{array}$ & $\begin{array}{l}1.37 \\
1.50\end{array}$ & $\begin{array}{r}2.88 \\
31.65\end{array}$ & $\begin{array}{l}0.18 \\
0.22\end{array}$ & $\begin{array}{l}0.778 \\
0.162\end{array}$ & $\begin{array}{l}9.4 \\
0.87\end{array}$ \\
\hline 8037 & 06803700 & North Fork Wahoo Creek tributary near Weston, Nebraska & $41 \quad 1300$ & 964900 & 8.90 & $\begin{array}{l}9.03 \\
9.03\end{array}$ & $\begin{array}{l}1.86 \\
17.2\end{array}$ & $\begin{array}{c}147 \\
42.3\end{array}$ & $\begin{array}{l}1.47 \\
1.25\end{array}$ & $\begin{array}{r}2.94 \\
28.45\end{array}$ & $\begin{array}{l}0.17 \\
0.19\end{array}$ & $\begin{array}{l}0.664 \\
0.288\end{array}$ & $\begin{array}{c}11.8 \\
0.67\end{array}$ \\
\hline 8039 & 06803900 & North Fork Wahoo Creek at Weston, Nebraska & $\begin{array}{lll}41 & 12 & 19\end{array}$ & 964339 & 43.3 & $\begin{array}{l}43.5 \\
43.5\end{array}$ & $\begin{array}{c}2.99 \\
10.9\end{array}$ & $\begin{array}{l}182 \\
21.7\end{array}$ & $\begin{array}{l}1.53 \\
1.37\end{array}$ & $\begin{array}{r}2.92 \\
32.37\end{array}$ & $\begin{array}{l}0.18 \\
0.23\end{array}$ & $\begin{array}{l}0.690 \\
0.119\end{array}$ & $\begin{array}{l}9.3 \\
0.82\end{array}$ \\
\hline 8040 & 06804000 & Wahoo Creek at Ithaca, Nebraska & 41840 & 963209 & 271 & $\begin{array}{l}273 \\
268\end{array}$ & $\begin{array}{l}1.01 \\
5.94\end{array}$ & $\begin{array}{c}148 \\
11.6\end{array}$ & $\begin{array}{l}1.54 \\
1.03\end{array}$ & $\begin{array}{r}2.93 \\
32.77\end{array}$ & $\begin{array}{l}0.19 \\
0.25\end{array}$ & $\begin{array}{l}0.369 \\
0.078\end{array}$ & $\begin{array}{l}7.1 \\
0.95\end{array}$ \\
\hline 8041 & 06804100 & Silver Creek near Cedar Bluffs, Nebraska & 412248 & 963515 & 7.00 & $\begin{array}{l}7.01 \\
6.70\end{array}$ & $\begin{array}{l}1.03 \\
8.30\end{array}$ & $\begin{array}{l}61.3 \\
23.2\end{array}$ & $\begin{array}{l}1.51 \\
0.654\end{array}$ & $\begin{array}{r}2.95 \\
30.42\end{array}$ & $\begin{array}{l}0.19 \\
0.29\end{array}$ & $\begin{array}{l}0.299 \\
0.379\end{array}$ & $\begin{array}{l}4.2 \\
1.32\end{array}$ \\
\hline 8042 & 06804200 & Silver Creek near Colon, Nebraska & $41 \quad 1825$ & 963347 & 30.3 & $\begin{array}{l}30.0 \\
23.4\end{array}$ & $\begin{array}{l}3.44 \\
4.07\end{array}$ & $\begin{array}{r}45.1 \\
5.8\end{array}$ & $\begin{array}{l}1.98 \\
0.832\end{array}$ & $\begin{array}{r}2.95 \\
30.56\end{array}$ & $\begin{array}{l}0.19 \\
0.21\end{array}$ & $\begin{array}{l}0.299 \\
0.129\end{array}$ & $\begin{array}{l}2.9 \\
1.07\end{array}$ \\
\hline 8043 & 06804300 & Silver Creek tributary near Colon, Nebraska & 412102 & 963844 & 10.3 & $\begin{array}{c}10.2 \\
7.30\end{array}$ & $\begin{array}{l}4.26 \\
3.50\end{array}$ & $\begin{array}{l}12.8 \\
10.9\end{array}$ & $\begin{array}{l}1.86 \\
0.770\end{array}$ & $\begin{array}{r}2.95 \\
30.43\end{array}$ & $\begin{array}{l}0.19 \\
0.18\end{array}$ & $\begin{array}{l}0.137 \\
0.849\end{array}$ & $\begin{array}{l}1.6 \\
1.02\end{array}$ \\
\hline 8044 & 06804400 & Silver Creek tributary at Colon, Nebraska & $41 \quad 1754$ & 963617 & 17.6 & $\begin{array}{l}17.6 \\
14.3\end{array}$ & $\begin{array}{l}6.60 \\
3.20\end{array}$ & $\begin{array}{r}14.2 \\
9.1\end{array}$ & $\begin{array}{l}2.30 \\
0.707\end{array}$ & $\begin{array}{r}2.95 \\
31.75\end{array}$ & $\begin{array}{l}0.19 \\
0.18\end{array}$ & $\begin{array}{l}0.140 \\
0.642\end{array}$ & $\begin{array}{l}1.6 \\
1.02\end{array}$ \\
\hline 8045 & 06804500 & Silver Creek at Ithaca, Nebraska & 410943 & 963138 & 80 & $\begin{array}{l}77.0 \\
64.1\end{array}$ & $\begin{array}{l}6.10 \\
4.29\end{array}$ & $\begin{array}{r}33.1 \\
7.4\end{array}$ & $\begin{array}{l}2.13 \\
0.708\end{array}$ & $\begin{array}{r}2.95 \\
32.37\end{array}$ & $\begin{array}{l}0.19 \\
0.19\end{array}$ & $\begin{array}{l}0.156 \\
0.224\end{array}$ & $\begin{array}{l}2.1 \\
1.04\end{array}$ \\
\hline
\end{tabular}


Table B1. Selected drainage-basin characteristics for streamflow-gaging stations in Nebraska and for selected out-of-state stations--Continued

\begin{tabular}{|c|c|c|c|c|c|c|c|c|c|c|c|c|c|c|}
\hline \multirow{2}{*}{\multicolumn{2}{|c|}{ 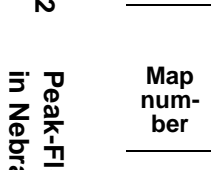 }} & \multirow[b]{2}{*}{$\begin{array}{l}\text { Station } \\
\text { number }\end{array}$} & \multirow[b]{2}{*}{ Station name-remarks } & \multirow[b]{2}{*}{$\begin{array}{c}\text { Latitude } \\
\left({ }^{0},{ }^{\prime}\right)\end{array}$} & \multirow[b]{2}{*}{$\underset{\left(0,{ }^{0}\right)}{\text { Longitude }}$} & \multirow{2}{*}{$\begin{array}{l}\text { Published } \\
\text { total } \\
\text { drainage } \\
\text { area } \\
\left(\mathrm{mi}^{2}\right)\end{array}$} & \multicolumn{8}{|c|}{ Drainage-basin characteristics } \\
\hline & & & & & & & $\begin{array}{l}\text { TDA } \\
\text { CDA }\end{array}$ & $\begin{array}{l}\text { SF } \\
\text { RR }\end{array}$ & $\begin{array}{c}\text { BS } \\
\text { MCS }\end{array}$ & $\begin{array}{l}\text { CR } \\
\text { SD }\end{array}$ & $\begin{array}{l}\text { TTP } \\
\text { MAP }\end{array}$ & $\begin{array}{l}\text { AWC } \\
\text { PLP }\end{array}$ & $\begin{array}{l}\text { DF } \\
\text { SR }\end{array}$ & $\begin{array}{l}\text { MSS } \\
\text { P60 }\end{array}$ \\
\hline ब & 8050 & 06805000 & Salt Creek near Ashland, Nebraska & 410249 & 962030 & 1640 & $\begin{array}{l}1640 \\
1640\end{array}$ & $\begin{array}{l}1.71 \\
0.81\end{array}$ & $\begin{array}{r}27.1 \\
1.4\end{array}$ & $\begin{array}{l}1.63 \\
1.04\end{array}$ & $\begin{array}{r}2.97 \\
30.34\end{array}$ & $\begin{array}{l}0.18 \\
0.24\end{array}$ & $\begin{array}{l}0.372 \\
0.052\end{array}$ & $\begin{array}{l}7.4 \\
0.88\end{array}$ \\
\hline 욛 & $8055 \mathrm{~b}$ & 06805510 & Buffalo Creek near Gretna, Nebraska & $4106 \quad 12$ & 961330 & 4.29 & $\begin{array}{l}4.32 \\
4.32\end{array}$ & $\begin{array}{c}0.700 \\
10.6\end{array}$ & $\begin{array}{l}95.5 \\
26.6\end{array}$ & $\begin{array}{l}1.35 \\
1.23\end{array}$ & $\begin{array}{r}3.05 \\
29.66\end{array}$ & $\begin{array}{l}0.20 \\
0.60\end{array}$ & $\begin{array}{l}0.695 \\
0.278\end{array}$ & $\begin{array}{l}9.3 \\
1.27\end{array}$ \\
\hline 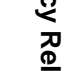 & 8064 & 06806400 & Weeping Water Creek at Elmwood, Nebraska & 405059 & 961659 & 20.8 & $\begin{array}{l}20.6 \\
20.6\end{array}$ & $\begin{array}{l}1.32 \\
5.72\end{array}$ & $\begin{array}{l}86.5 \\
14.9\end{array}$ & $\begin{array}{l}1.28 \\
1.02\end{array}$ & $\begin{array}{r}3.05 \\
32.79\end{array}$ & $\begin{array}{l}0.18 \\
0.18\end{array}$ & $\begin{array}{l}0.388 \\
0.173\end{array}$ & $\begin{array}{l}7.0 \\
0.77\end{array}$ \\
\hline 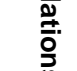 & $8064 \mathrm{~b}$ & 06806420 & Stove Creek near Elmwood, Nebraska & 404859 & 961800 & 5.23 & $\begin{array}{l}5.28 \\
5.28\end{array}$ & $\begin{array}{l}0.761 \\
9.44\end{array}$ & $\begin{array}{l}52.8 \\
29.4\end{array}$ & $\begin{array}{l}1.28 \\
0.423\end{array}$ & $\begin{array}{r}3.05 \\
32.87\end{array}$ & $\begin{array}{l}0.17 \\
0.13\end{array}$ & $\begin{array}{l}0.189 \\
0.557\end{array}$ & $\begin{array}{l}6.0 \\
0.47\end{array}$ \\
\hline $\begin{array}{l}\infty \\
\stackrel{\infty}{3}\end{array}$ & $8064 \mathrm{c}$ & 06806440 & Stove Creek at Elmwood, Nebraska & $40 \quad 5031$ & 961736 & 10.3 & $\begin{array}{l}10.3 \\
10.3\end{array}$ & $\begin{array}{l}1.53 \\
7.39\end{array}$ & $\begin{array}{l}76.5 \\
22.0\end{array}$ & $\begin{array}{l}1.41 \\
0.634\end{array}$ & $\begin{array}{r}3.05 \\
32.89\end{array}$ & $\begin{array}{l}0.17 \\
0.15\end{array}$ & $\begin{array}{l}0.194 \\
0.287\end{array}$ & $\begin{array}{l}6.2 \\
0.56\end{array}$ \\
\hline$\underset{\Phi}{m}$ & $8064 \mathrm{~d}$ & 06806460 & Weeping Water Creek at Weeping Water, Nebraska & $4051 \quad 17$ & $9607 \quad 10$ & 80.1 & $\begin{array}{l}80.2 \\
80.2\end{array}$ & $\begin{array}{l}1.74 \\
5.60\end{array}$ & $\begin{array}{l}117 \\
14.0\end{array}$ & $\begin{array}{l}1.64 \\
0.951\end{array}$ & $\begin{array}{r}3.05 \\
32.91\end{array}$ & $\begin{array}{l}0.19 \\
0.24\end{array}$ & $\begin{array}{l}0.337 \\
0.119\end{array}$ & $\begin{array}{l}6.9 \\
0.95\end{array}$ \\
\hline 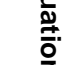 & $8064 \mathrm{e}$ & 06806470 & $\begin{array}{l}\text { Weeping Water Creek tributary near Weeping Water, } \\
\text { Nebraska }\end{array}$ & 405146 & 960643 & 0.73 & 0.73 & $\begin{array}{l}-- \\
--\end{array}$ & $\begin{array}{l}-- \\
--\end{array}$ & $\begin{array}{l}-- \\
--\end{array}$ & $\begin{array}{l}3.05 \\
--\end{array}$ & $\begin{array}{l}0.19 \\
0.24\end{array}$ & $\begin{array}{l}-- \\
--\end{array}$ & $\begin{array}{l}7.7 \\
1.04\end{array}$ \\
\hline$\stackrel{0}{\stackrel{0}{\rightleftarrows}}$ & 8065 & 06806500 & Weeping Water Creek at Union, Nebraska & 404735 & 955439 & 241 & $\begin{array}{l}241 \\
241\end{array}$ & $\begin{array}{l}2.52 \\
4.00\end{array}$ & $\begin{array}{c}153 \\
12.0\end{array}$ & $\begin{array}{l}1.80 \\
0.769\end{array}$ & $\begin{array}{r}3.06 \\
32.81\end{array}$ & $\begin{array}{l}0.19 \\
0.25\end{array}$ & $\begin{array}{l}0.220 \\
0.078\end{array}$ & $\begin{array}{l}7.1 \\
0.89\end{array}$ \\
\hline $\mathbb{D}_{0}^{\infty}$ & $8077 \mathrm{a}$ & 06807720 & Middle Silver Creek near Avoca, Iowa & 412833 & 952805 & 3.21 & $\begin{array}{l}3.38 \\
3.38\end{array}$ & $\begin{array}{l}2.05 \\
14.4\end{array}$ & $\begin{array}{c}168 \\
5.3\end{array}$ & $\begin{array}{l}1.23 \\
0.739\end{array}$ & $\begin{array}{r}3.05 \\
32.46\end{array}$ & $\begin{array}{l}0.20 \\
0.59\end{array}$ & $\begin{array}{l}0.296 \\
0.031\end{array}$ & $\begin{array}{l}9.4 \\
1.33\end{array}$ \\
\hline 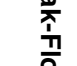 & $8077 \mathrm{~b}$ & 06807760 & Middle Silver Creek near Oakland, Iowa & $41 \quad 1927$ & 953318 & 25.7 & $\begin{array}{l}25.9 \\
25.9\end{array}$ & $\begin{array}{l}8.70 \\
6.60\end{array}$ & $\begin{array}{c}187 \\
9.8\end{array}$ & $\begin{array}{l}2.01 \\
0.589\end{array}$ & $\begin{array}{r}3.05 \\
32.33\end{array}$ & $\begin{array}{l}0.20 \\
0.59\end{array}$ & $\begin{array}{l}0.039 \\
0.052\end{array}$ & $\begin{array}{l}9.5 \\
1.34\end{array}$ \\
\hline 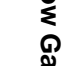 & $8077 \mathrm{c}$ & 06807780 & Middle Silver Creek at Treynor, Iowa & 411436 & 953653 & 42.7 & $\begin{array}{l}42.8 \\
42.8\end{array}$ & $\begin{array}{l}11.0 \\
5.90\end{array}$ & $\begin{array}{c}197 \\
9.8\end{array}$ & $\begin{array}{l}2.11 \\
0.576\end{array}$ & $\begin{array}{r}3.05 \\
32.33\end{array}$ & $\begin{array}{l}0.20 \\
0.59\end{array}$ & $\begin{array}{l}0.047 \\
0.050\end{array}$ & $\begin{array}{l}9.5 \\
1.34\end{array}$ \\
\hline 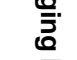 & $8100 \mathrm{~b}$ & 06810060 & Honey Creek near Peru, Nebraska & 402638 & $95 \quad 4511$ & 3.43 & $\begin{array}{l}3.43 \\
3.43\end{array}$ & $\begin{array}{c}0.639 \\
16.0\end{array}$ & $\begin{array}{l}80.8 \\
42.2\end{array}$ & $\begin{array}{l}1.25 \\
0.841\end{array}$ & $\begin{array}{r}3.15 \\
31.73\end{array}$ & $\begin{array}{l}0.20 \\
0.60\end{array}$ & $\begin{array}{l}0.583 \\
0.523\end{array}$ & $\begin{array}{c}10.4 \\
1.28\end{array}$ \\
\hline$\stackrel{\$}{\$}$ & 8101 & 06810100 & Hooper Creek tributary near Palmyra, Nebraska & 404609 & 962522 & 8.00 & $\begin{array}{l}8.11 \\
8.11\end{array}$ & $\begin{array}{c}3.49 \\
11.4\end{array}$ & $\begin{array}{l}96.0 \\
21.9\end{array}$ & $\begin{array}{l}1.48 \\
1.06\end{array}$ & $\begin{array}{r}3.05 \\
32.26\end{array}$ & $\begin{array}{l}0.17 \\
0.18\end{array}$ & $\begin{array}{l}0.493 \\
0.228\end{array}$ & $\begin{array}{l}7.8 \\
0.67\end{array}$ \\
\hline 긋 & 8102 & 06810200 & Hooper Creek near Palmyra, Nebraska & 404300 & 961900 & 57.6 & $\begin{array}{l}59.6 \\
59.6\end{array}$ & $\begin{array}{l}2.29 \\
6.03\end{array}$ & $\begin{array}{c}111 \\
15.9\end{array}$ & $\begin{array}{l}1.71 \\
1.02\end{array}$ & $\begin{array}{r}3.05 \\
32.10\end{array}$ & $\begin{array}{l}0.16 \\
0.15\end{array}$ & $\begin{array}{l}0.369 \\
0.143\end{array}$ & $\begin{array}{l}6.6 \\
0.45\end{array}$ \\
\hline & 8103 & 06810300 & Wolf Creek near Syracuse, Nebraska & 404000 & 961300 & 25.4 & $\begin{array}{l}26.3 \\
26.3\end{array}$ & $\begin{array}{c}3.79 \\
10.6\end{array}$ & $\begin{array}{c}128 \\
21.4\end{array}$ & $\begin{array}{l}1.52 \\
1.06\end{array}$ & $\begin{array}{r}3.05 \\
30.69\end{array}$ & $\begin{array}{l}0.16 \\
0.18\end{array}$ & $\begin{array}{l}0.494 \\
0.167\end{array}$ & $\begin{array}{l}6.7 \\
0.44\end{array}$ \\
\hline & 8105 & 06810500 & Little Nemaha River near Syracuse, Nebraska & 403757 & 961045 & 218 & $\begin{array}{l}209 \\
209\end{array}$ & $\begin{array}{l}2.30 \\
5.24\end{array}$ & $\begin{array}{l}121 \\
12.5\end{array}$ & $\begin{array}{l}1.59 \\
0.931\end{array}$ & $\begin{array}{r}3.05 \\
31.69\end{array}$ & $\begin{array}{l}0.16 \\
0.17\end{array}$ & $\begin{array}{l}0.301 \\
0.103\end{array}$ & $\begin{array}{l}6.5 \\
0.44\end{array}$ \\
\hline & 8115 & 06811500 & Little Nemaha River at Auburn, Nebraska & 402332 & 954846 & 793 & $\begin{array}{l}793 \\
793\end{array}$ & $\begin{array}{l}2.76 \\
3.20\end{array}$ & $\begin{array}{c}155 \\
6.6\end{array}$ & $\begin{array}{l}1.74 \\
0.771\end{array}$ & $\begin{array}{r}3.10 \\
31.65\end{array}$ & $\begin{array}{l}0.16 \\
0.19\end{array}$ & $\begin{array}{l}0.207 \\
0.042\end{array}$ & $\begin{array}{l}6.2 \\
0.54\end{array}$ \\
\hline & 8130 & 06813000 & Tarkio River at Fairfax, Missouri & 402020 & 952432 & 508 & $\begin{array}{l}479 \\
479\end{array}$ & $\begin{array}{l}8.74 \\
3.17\end{array}$ & $\begin{array}{c}145 \\
4.7\end{array}$ & $\begin{array}{l}1.94 \\
0.423\end{array}$ & $\begin{array}{r}3.20 \\
34.50\end{array}$ & $\begin{array}{l}0.19 \\
0.49\end{array}$ & $\begin{array}{l}0.040 \\
0.032\end{array}$ & $\begin{array}{l}8.8 \\
1.09\end{array}$ \\
\hline & 8140 & 06814000 & Turkey Creek near Seneca, Kansas & 395652 & 960629 & 276 & $\begin{array}{l}277 \\
277\end{array}$ & $\begin{array}{l}4.43 \\
5.10\end{array}$ & $\begin{array}{r}131 \\
8.4\end{array}$ & $\begin{array}{l}1.59 \\
0.879\end{array}$ & $\begin{array}{r}3.21 \\
32.35\end{array}$ & $\begin{array}{l}0.15 \\
0.19\end{array}$ & $\begin{array}{l}0.268 \\
0.064\end{array}$ & $\begin{array}{l}7.6 \\
0.45\end{array}$ \\
\hline
\end{tabular}


Table B1. Selected drainage-basin characteristics for streamflow-gaging stations in Nebraska and for selected out-of-state stations--Continued

\begin{tabular}{|c|c|c|c|c|c|c|c|c|c|c|c|c|c|}
\hline \multirow[b]{2}{*}{$\begin{array}{c}\text { Map } \\
\text { num- } \\
\text { ber }\end{array}$} & \multirow[b]{2}{*}{$\begin{array}{l}\text { Station } \\
\text { number }\end{array}$} & \multirow[b]{2}{*}{ Station name—remarks } & \multirow[b]{2}{*}{$\begin{array}{c}\text { Latitude } \\
(0, ")\end{array}$} & \multirow[b]{2}{*}{$\begin{array}{c}\text { Longitude } \\
\left({ }^{0},{ }^{\prime}\right)\end{array}$} & \multirow{2}{*}{$\begin{array}{c}\text { Published } \\
\text { total } \\
\text { drainage } \\
\text { area } \\
\left(\mathrm{mi}^{2}\right)\end{array}$} & \multicolumn{8}{|c|}{ Drainage-basin characteristics } \\
\hline & & & & & & $\begin{array}{l}\text { TDA } \\
\text { CDA }\end{array}$ & $\begin{array}{l}\text { SF } \\
\text { RR }\end{array}$ & $\begin{array}{l}\text { BS } \\
\text { MCS }\end{array}$ & $\begin{array}{l}\text { CR } \\
\text { SD }\end{array}$ & $\begin{array}{l}\text { TTP } \\
\text { MAP }\end{array}$ & $\begin{array}{l}\text { AWC } \\
\text { PLP }\end{array}$ & $\begin{array}{l}\text { DF } \\
\text { SR }\end{array}$ & $\begin{array}{l}\text { MSS } \\
\text { P60 }\end{array}$ \\
\hline 8145 & 06814500 & North Fork Big Nemaha River at Humboldt, Nebraska & 400924 & 955639 & 548 & $\begin{array}{l}549 \\
549\end{array}$ & $\begin{array}{l}5.12 \\
3.01\end{array}$ & $\begin{array}{c}153 \\
7.8\end{array}$ & $\begin{array}{l}2.07 \\
0.739\end{array}$ & $\begin{array}{r}3.13 \\
31.70\end{array}$ & $\begin{array}{l}0.16 \\
0.19\end{array}$ & $\begin{array}{l}0.191 \\
0.051\end{array}$ & $\begin{array}{l}7.3 \\
0.48\end{array}$ \\
\hline 8150 & 06815000 & Big Nemaha River at Falls City, Nebraska & 400159 & 953530 & 1,340 & $\begin{array}{l}1,340 \\
1,340\end{array}$ & $\begin{array}{l}4.46 \\
2.55\end{array}$ & $\begin{array}{c}149 \\
6.2\end{array}$ & $\begin{array}{l}2.02 \\
0.808\end{array}$ & $\begin{array}{r}3.20 \\
32.54\end{array}$ & $\begin{array}{l}0.15 \\
0.18\end{array}$ & $\begin{array}{l}0.215 \\
0.042\end{array}$ & $\begin{array}{l}7.6 \\
0.46\end{array}$ \\
\hline 8155 & 06815500 & Muddy Creek at Verdon, Nebraska & 400840 & 954309 & 186 & $\begin{array}{l}186 \\
186\end{array}$ & $\begin{array}{l}3.84 \\
4.73\end{array}$ & $\begin{array}{r}93.4 \\
9.2\end{array}$ & $\begin{array}{l}1.71 \\
0.821\end{array}$ & $\begin{array}{r}3.21 \\
32.57\end{array}$ & $\begin{array}{l}0.16 \\
0.17\end{array}$ & $\begin{array}{l}0.177 \\
0.098\end{array}$ & $\begin{array}{l}6.2 \\
0.48\end{array}$ \\
\hline 8155b & 06815510 & Temple Creek near Falls City, Nebraska & 400836 & 953627 & 2.99 & $\begin{array}{l}3.03 \\
3.03\end{array}$ & $\begin{array}{c}2.38 \\
15.6\end{array}$ & $\begin{array}{l}90.7 \\
39.0\end{array}$ & $\begin{array}{l}1.36 \\
0.927\end{array}$ & $\begin{array}{r}3.25 \\
34.08\end{array}$ & $\begin{array}{l}0.20 \\
0.58\end{array}$ & $\begin{array}{l}0.331 \\
0.430\end{array}$ & $\begin{array}{l}8.6 \\
1.24\end{array}$ \\
\hline $8155 \mathrm{c}$ & 06815550 & Staples Branch near Burlington Junction, Missouri & 402615 & $95 \quad 1204$ & 0.49 & $\begin{array}{l}0.43 \\
0.43\end{array}$ & $\begin{array}{l}2.15 \\
18.5\end{array}$ & $\begin{array}{r}86.0 \\
4.3\end{array}$ & $\begin{array}{l}1.22 \\
2.39\end{array}$ & $\begin{array}{r}3.25 \\
33.37\end{array}$ & $\begin{array}{l}0.18 \\
0.25\end{array}$ & $\begin{array}{l}2.33 \\
0.050\end{array}$ & $\begin{array}{c}10.0 \\
0.83\end{array}$ \\
\hline 8160 & 06816000 & Mill Creek at Oregon, Missouri & 395855 & $95 \quad 1204$ & 4.90 & $\begin{array}{l}4.44 \\
4.44\end{array}$ & $\begin{array}{l}1.69 \\
12.3\end{array}$ & $\begin{array}{l}129 \\
20.3\end{array}$ & $\begin{array}{l}1.11 \\
0.680\end{array}$ & $\begin{array}{r}3.35 \\
35.96\end{array}$ & $\begin{array}{l}0.21 \\
0.59\end{array}$ & $\begin{array}{l}0.225 \\
0.157\end{array}$ & $\begin{array}{c}20.3 \\
1.29\end{array}$ \\
\hline 8200 & 06820000 & White Cloud Creek near Maryville, Missouri & 402322 & 945432 & 6.00 & $\begin{array}{l}5.66 \\
5.66\end{array}$ & $\begin{array}{c}4.84 \\
10.1\end{array}$ & $\begin{array}{c}114 \\
16.8\end{array}$ & $\begin{array}{l}1.42 \\
0.969\end{array}$ & $\begin{array}{r}3.25 \\
34.28\end{array}$ & $\begin{array}{l}0.18 \\
0.26\end{array}$ & $\begin{array}{l}0.177 \\
0.147\end{array}$ & $\begin{array}{l}7.0 \\
1.00\end{array}$ \\
\hline 8210 & 06821000 & Jenkins Branch at Gower, Missouri & 393728 & 943600 & 2.72 & $\begin{array}{l}2.39 \\
2.39\end{array}$ & $\begin{array}{l}2.65 \\
11.1\end{array}$ & $\begin{array}{l}58.4 \\
28.5\end{array}$ & $\begin{array}{l}1.13 \\
1.09\end{array}$ & $\begin{array}{r}3.45 \\
38.47\end{array}$ & $\begin{array}{l}0.18 \\
0.25\end{array}$ & $\begin{array}{l}0.418 \\
0.487\end{array}$ & $\begin{array}{c}10.0 \\
0.83\end{array}$ \\
\hline 8215 & 06821500 & Arikaree River at Haigler, Nebraska & 400145 & 1015809 & 1,700 & $\begin{array}{l}1,700 \\
1,020\end{array}$ & $\begin{array}{l}12.1 \\
9.55\end{array}$ & $\begin{array}{l}80.8 \\
17.6\end{array}$ & $\begin{array}{l}2.48 \\
0.838\end{array}$ & $\begin{array}{r}2.05 \\
16.54\end{array}$ & $\begin{array}{l}0.14 \\
1.32\end{array}$ & $\begin{array}{l}0.151 \\
0.218\end{array}$ & $\begin{array}{r}10.1 \\
4.11\end{array}$ \\
\hline 8230 & 06823000 & $\begin{array}{l}\text { North Fork Republican River at Colorado-Nebraska state } \\
\text { line }\end{array}$ & 400409 & 1020305 & 2,370 & $\begin{array}{r}2,360 \\
174\end{array}$ & $\begin{array}{l}3.81 \\
6.74\end{array}$ & $\begin{array}{l}71.5 \\
14.8\end{array}$ & $\begin{array}{l}5.24 \\
4.62\end{array}$ & $\begin{array}{r}2.06 \\
16.50\end{array}$ & $\begin{array}{l}0.13 \\
1.84\end{array}$ & $\begin{array}{l}0.954 \\
0.207\end{array}$ & $\begin{array}{l}9.7 \\
5.53\end{array}$ \\
\hline 8235 & 06823500 & Buffalo Creek near Haigler, Nebraska & 400221 & 1015156 & 172 & $\stackrel{172}{8.60}$ & $\begin{array}{l}157 \\
6.05\end{array}$ & $\begin{array}{l}69.9 \\
14.9\end{array}$ & $\begin{array}{l}11.2 \\
4.75\end{array}$ & $\begin{array}{r}2.15 \\
17.67\end{array}$ & $\begin{array}{l}0.08 \\
4.96\end{array}$ & $\begin{array}{l}0.233 \\
0.213\end{array}$ & $\begin{array}{l}17.3 \\
13.01\end{array}$ \\
\hline 8245 & 06824500 & Republican River at Benkelman, Nebraska & 400154 & 1013230 & 4,830 & $\begin{array}{l}4,870 \\
1,230\end{array}$ & $\begin{array}{l}15.2 \\
7.00\end{array}$ & $\begin{array}{l}70.4 \\
17.0\end{array}$ & $\begin{array}{l}3.41 \\
1.46\end{array}$ & $\begin{array}{r}2.07 \\
16.71\end{array}$ & $\begin{array}{l}0.13 \\
2.00\end{array}$ & $\begin{array}{l}0.279 \\
0.242\end{array}$ & $\begin{array}{c}10.8 \\
5.82\end{array}$ \\
\hline 8250 & 06825000 & South Fork Republican River near Idalia, Colorado & 393659 & 1021431 & 1,300 & $\begin{array}{l}1,460 \\
1,460\end{array}$ & $\begin{array}{l}3.58 \\
9.74\end{array}$ & $\begin{array}{l}110 \\
18.5\end{array}$ & $\begin{array}{l}1.33 \\
0.580\end{array}$ & $\begin{array}{r}2.06 \\
16.28\end{array}$ & $\begin{array}{l}0.15 \\
0.96\end{array}$ & $\begin{array}{l}0.088 \\
0.169\end{array}$ & $\begin{array}{c}10.7 \\
2.89\end{array}$ \\
\hline 8255 & 06825500 & Landsman Creek near Hale, Colorado & 393431 & 1021506 & 268 & $\begin{array}{l}270 \\
270\end{array}$ & $\begin{array}{l}8.82 \\
9.58\end{array}$ & $\begin{array}{l}131 \\
16.8\end{array}$ & $\begin{array}{l}1.88 \\
0.650\end{array}$ & $\begin{array}{r}2.11 \\
16.51\end{array}$ & $\begin{array}{l}0.17 \\
0.45\end{array}$ & $\begin{array}{l}0.104 \\
0.129\end{array}$ & $\begin{array}{l}7.2 \\
1.49\end{array}$ \\
\hline 8280 & 06828000 & Republican River at Max, Nebraska & 400610 & 1012349 & 7,580 & $\begin{array}{l}7,740 \\
4,450\end{array}$ & $\begin{array}{l}4.04 \\
6.83\end{array}$ & $\begin{array}{l}82.5 \\
15.4\end{array}$ & $\begin{array}{l}1.91 \\
0.835\end{array}$ & $\begin{array}{r}2.09 \\
16.78\end{array}$ & $\begin{array}{l}0.14 \\
1.59\end{array}$ & $\begin{array}{l}0.161 \\
0.187\end{array}$ & $\begin{array}{c}10.3 \\
4.58\end{array}$ \\
\hline 8281 & 06828100 & North Branch Indian Creek near Max, Nebraska & 400952 & 1012351 & 4.76 & $\begin{array}{l}3.75 \\
3.75\end{array}$ & $\begin{array}{l}2.50 \\
30.8\end{array}$ & $\begin{array}{c}166 \\
61.8\end{array}$ & $\begin{array}{l}1.24 \\
0.775\end{array}$ & $\begin{array}{r}2.25 \\
18.43\end{array}$ & $\begin{array}{l}0.20 \\
0.59\end{array}$ & $\begin{array}{l}0.267 \\
0.373\end{array}$ & $\begin{array}{l}8.3 \\
1.29\end{array}$ \\
\hline 8297 & 06829700 & Thompson Canyon near Trenton, Nebraska & 400944 & 1005731 & 9.06 & $\begin{array}{l}9.10 \\
9.10\end{array}$ & $\begin{array}{l}2.14 \\
19.7\end{array}$ & $\begin{array}{l}148 \\
52.0\end{array}$ & $\begin{array}{l}1.25 \\
0.884\end{array}$ & $\begin{array}{r}2.25 \\
20.80\end{array}$ & $\begin{array}{l}0.20 \\
0.59\end{array}$ & $\begin{array}{l}0.220 \\
0.349\end{array}$ & $\begin{array}{l}8.8 \\
1.29\end{array}$ \\
\hline 8345 & 06834500 & $\begin{array}{l}\text { Stinking Water Creek near Wauneta, Nebraska-CDA } \\
\text { known to be much less based on station } 06835000\end{array}$ & $\begin{array}{ll}40 & 29 \\
20\end{array}$ & 1011930 & 1,330 & $\begin{array}{l}1,340 \\
\underline{1,340}\end{array}$ & $\frac{1.02}{5.54}$ & $\begin{array}{l}60.2 \\
11.0\end{array}$ & $\begin{array}{l}1.81 \\
0.256\end{array}$ & $\begin{array}{r}2.16 \\
18.12\end{array}$ & $\begin{array}{l}0.13 \\
1.89\end{array}$ & $\begin{array}{l}0.036 \\
0.182\end{array}$ & $\begin{array}{l}7.9 \\
5.13\end{array}$ \\
\hline 8350 & 06835000 & Stinking Water Creek near Palisade, Nebraska & 402209 & 1010650 & 1,500 & $\begin{array}{r}1,510 \\
380\end{array}$ & $\begin{array}{l}6.34 \\
5.64\end{array}$ & $\begin{array}{l}71.1 \\
11.0\end{array}$ & $\begin{array}{l}3.69 \\
1.05\end{array}$ & $\begin{array}{r}2.10 \\
18.26\end{array}$ & $\begin{array}{l}0.13 \\
1.84\end{array}$ & $\begin{array}{l}0.155 \\
0.154\end{array}$ & $\begin{array}{l}7.7 \\
4.95\end{array}$ \\
\hline
\end{tabular}


Table B1. Selected drainage-basin characteristics for streamflow-gaging stations in Nebraska and for selected out-of-state stations--Continued

\begin{tabular}{|c|c|c|c|c|c|c|c|c|c|c|c|c|c|}
\hline \multirow[b]{2}{*}{$\begin{array}{c}\text { Map } \\
\text { num- } \\
\text { ber }\end{array}$} & \multirow[b]{2}{*}{$\begin{array}{c}\text { Station } \\
\text { number }\end{array}$} & \multirow[b]{2}{*}{ Station name-remarks } & \multirow[b]{2}{*}{$\begin{array}{c}\text { Latitude } \\
\left({ }^{0}, "\right)\end{array}$} & \multirow[b]{2}{*}{$\begin{array}{c}\text { Longitude } \\
\left({ }^{0}, \ldots\right)\end{array}$} & \multirow{2}{*}{$\begin{array}{c}\text { Published } \\
\text { total } \\
\text { drainage } \\
\text { area } \\
\left(\mathrm{mi}^{2}\right)\end{array}$} & \multicolumn{8}{|c|}{ Drainage-basin characteristics } \\
\hline & & & & & & $\begin{array}{l}\text { TDA } \\
\text { CDA }\end{array}$ & $\begin{array}{l}\text { SF } \\
\text { RR }\end{array}$ & $\begin{array}{l}\text { BS } \\
\text { MCS }\end{array}$ & $\begin{array}{l}\text { CR } \\
\text { SD }\end{array}$ & $\begin{array}{l}\text { TTP } \\
\text { MAP }\end{array}$ & $\begin{array}{l}\text { AWC } \\
\text { PLP }\end{array}$ & $\begin{array}{l}\text { DF } \\
\text { SR }\end{array}$ & $\begin{array}{l}\text { MSS } \\
\text { P60 }\end{array}$ \\
\hline 8351 & 06835100 & Bobtail Creek near Palisade, Nebraska & $4018 \quad 17$ & 1010640 & 30.2 & $\begin{array}{l}29.4 \\
28.2\end{array}$ & $\begin{array}{l}2.38 \\
15.1\end{array}$ & $\begin{array}{l}143 \\
28.6\end{array}$ & $\begin{array}{l}1.41 \\
0.583\end{array}$ & $\begin{array}{r}2.25 \\
21.15\end{array}$ & $\begin{array}{l}0.20 \\
0.58\end{array}$ & $\begin{array}{l}0.142 \\
0.200\end{array}$ & $\begin{array}{l}6.3 \\
1.28\end{array}$ \\
\hline 8360 & 06836000 & Blackwood Creek near Culbertson, Nebraska & 401409 & 1004838 & 320 & $\begin{array}{l}320 \\
320\end{array}$ & $\begin{array}{l}5.04 \\
6.66\end{array}$ & $\begin{array}{c}186 \\
12.9\end{array}$ & $\begin{array}{l}2.04 \\
0.575\end{array}$ & $\begin{array}{r}2.25 \\
20.38\end{array}$ & $\begin{array}{l}0.19 \\
0.76\end{array}$ & $\begin{array}{l}0.103 \\
0.069\end{array}$ & $\begin{array}{l}6.6 \\
1.72\end{array}$ \\
\hline 8371 & 06837100 & Ash Creek near Red Willow, Nebraska & 400945 & 1002924 & 18.32 & $\begin{array}{l}18.3 \\
18.3\end{array}$ & $\begin{array}{l}1.48 \\
12.6\end{array}$ & $\begin{array}{c}103 \\
23.9\end{array}$ & $\begin{array}{l}1.27 \\
1.02\end{array}$ & $\begin{array}{r}2.35 \\
20.71\end{array}$ & $\begin{array}{l}0.20 \\
0.60\end{array}$ & $\begin{array}{l}0.273 \\
0.232\end{array}$ & $\begin{array}{c}15.1 \\
1.30\end{array}$ \\
\hline 8373 & 06837300 & Red Willow Creek above Hugh Butler Lake, Nebraska & 402405 & 1004645 & 582 & $\begin{array}{l}582 \\
194\end{array}$ & $\begin{array}{l}15.9 \\
4.40\end{array}$ & $\begin{array}{r}96.8 \\
9.9\end{array}$ & $\begin{array}{l}3.55 \\
0.770\end{array}$ & $\begin{array}{r}2.25 \\
18.75\end{array}$ & $\begin{array}{l}0.14 \\
2.78\end{array}$ & $\begin{array}{l}0.108 \\
0.102\end{array}$ & $\begin{array}{l}11.4 \\
6.40\end{array}$ \\
\hline 8382 & 06838200 & Coon Creek at Indianola, Nebraska & 401403 & 1002537 & 69.0 & $\begin{array}{l}68.9 \\
68.9\end{array}$ & $\begin{array}{l}6.36 \\
10.4\end{array}$ & $\begin{array}{c}142 \\
15.0\end{array}$ & $\begin{array}{l}1.71 \\
0.664\end{array}$ & $\begin{array}{r}2.35 \\
20.39\end{array}$ & $\begin{array}{l}0.20 \\
0.60\end{array}$ & $\begin{array}{l}0.102 \\
0.105\end{array}$ & $\begin{array}{c}14.1 \\
1.29\end{array}$ \\
\hline 8390 & 06839000 & Medicine Creek at Maywood, Nebraska & 403920 & 1003639 & 231 & $\begin{array}{l}256 \\
79.0\end{array}$ & $\begin{array}{c}11.5 \\
5.88\end{array}$ & $\begin{array}{r}108.6 \\
17.9\end{array}$ & $\begin{array}{l}3.24 \\
0.700\end{array}$ & $\begin{array}{r}2.26 \\
20.25\end{array}$ & $\begin{array}{l}0.12 \\
4.23\end{array}$ & $\begin{array}{l}0.127 \\
0.165\end{array}$ & $\begin{array}{l}19.8 \\
9.42\end{array}$ \\
\hline 8392 & 06839200 & Elkhorn Canyon near Maywood, Nebraska & 403610 & 1004202 & 6.74 & $\begin{array}{l}6.78 \\
6.78\end{array}$ & $\begin{array}{l}1.94 \\
15.4\end{array}$ & $\begin{array}{c}253 \\
34.4\end{array}$ & $\begin{array}{l}1.41 \\
1.17\end{array}$ & $\begin{array}{r}2.25 \\
20.94\end{array}$ & $\begin{array}{l}0.20 \\
0.60\end{array}$ & $\begin{array}{l}0.590 \\
0.136\end{array}$ & $\begin{array}{c}25.8 \\
1.30\end{array}$ \\
\hline 8394 & 06839400 & Elkhorn Canyon southwest of Maywood, Nebraska & 403720 & 1003857 & 13.2 & $\begin{array}{l}13.2 \\
13.2\end{array}$ & $\begin{array}{l}2.00 \\
14.5\end{array}$ & $\begin{array}{c}255 \\
37.4\end{array}$ & $\begin{array}{l}1.62 \\
0.865\end{array}$ & $\begin{array}{r}2.29 \\
20.88\end{array}$ & $\begin{array}{l}0.20 \\
0.60\end{array}$ & $\begin{array}{l}0.227 \\
0.147\end{array}$ & $\begin{array}{c}23.9 \\
1.31\end{array}$ \\
\hline 8395 & 06839500 & Brushy Creek near Maywood, Nebraska & 403750 & 1003746 & 95 & ${ }_{72.0}^{108}$ & $\begin{array}{l}3.13 \\
7.86\end{array}$ & $\begin{array}{c}183 \\
28.2\end{array}$ & $\begin{array}{l}2.07 \\
0.853\end{array}$ & $\begin{array}{r}2.26 \\
21.01\end{array}$ & $\begin{array}{l}0.17 \\
1.84\end{array}$ & $\begin{array}{l}0.222 \\
0.154\end{array}$ & $\begin{array}{l}19.2 \\
4.34\end{array}$ \\
\hline 8396 & 06839600 & Frazier Creek near Maywood, Nebraska & 403505 & 1003745 & 11.3 & $\begin{array}{l}11.3 \\
11.3\end{array}$ & $\begin{array}{c}2.20 \\
17.9\end{array}$ & $\begin{array}{c}143 \\
46.3\end{array}$ & $\begin{array}{l}1.22 \\
0.923\end{array}$ & $\begin{array}{r}2.34 \\
20.83\end{array}$ & $\begin{array}{l}0.20 \\
0.60\end{array}$ & $\begin{array}{l}0.266 \\
0.324\end{array}$ & $\begin{array}{c}19.3 \\
1.32\end{array}$ \\
\hline 8398a & 06839850 & Fox Creek north of Curtis, Nebraska & 404935 & 1003124 & 13.8 & $\begin{array}{l}13.4 \\
13.4\end{array}$ & $\begin{array}{l}1.69 \\
18.4\end{array}$ & $\begin{array}{c}378 \\
27.2\end{array}$ & $\begin{array}{l}1.33 \\
1.02\end{array}$ & $\begin{array}{r}2.35 \\
21.00\end{array}$ & $\begin{array}{l}0.20 \\
0.60\end{array}$ & $\begin{array}{l}0.448 \\
0.072\end{array}$ & $\begin{array}{c}26.8 \\
1.30\end{array}$ \\
\hline 8399 & 06839900 & Fox Creek above Cut Canyon near Curtis, Nebraska & 404440 & 1003151 & 31.8 & $\begin{array}{l}31.4 \\
31.4\end{array}$ & $\begin{array}{c}3.48 \\
12.6\end{array}$ & $\begin{array}{c}333 \\
24.0\end{array}$ & $\begin{array}{l}1.60 \\
0.895\end{array}$ & $\begin{array}{r}2.35 \\
21.00\end{array}$ & $\begin{array}{l}0.20 \\
0.60\end{array}$ & $\begin{array}{l}0.255 \\
0.072\end{array}$ & $\begin{array}{c}26.0 \\
1.30\end{array}$ \\
\hline $8399 \mathrm{~b}$ & 06839950 & Cut Canyon near Curtis, Nebraska & 404339 & 1003209 & 25.6 & $\begin{array}{l}25.6 \\
25.6\end{array}$ & $\begin{array}{c}8.07 \\
13.7\end{array}$ & $\begin{array}{c}338 \\
18.2\end{array}$ & $\begin{array}{l}2.04 \\
0.969\end{array}$ & $\begin{array}{r}2.34 \\
20.90\end{array}$ & $\begin{array}{l}0.20 \\
0.60\end{array}$ & $\begin{array}{l}0.274 \\
0.054\end{array}$ & $\begin{array}{c}25.7 \\
1.30\end{array}$ \\
\hline 8400 & 06840000 & Fox Creek at Curtis, Nebraska & 403759 & 1002920 & 72.6 & $\begin{array}{l}72.5 \\
72.5\end{array}$ & $\begin{array}{c}3.90 \\
11.1\end{array}$ & $\begin{array}{l}318 \\
21.6\end{array}$ & $\begin{array}{l}1.88 \\
0.923\end{array}$ & $\begin{array}{r}2.35 \\
20.87\end{array}$ & $\begin{array}{l}0.20 \\
0.59\end{array}$ & $\begin{array}{l}0.234 \\
0.068\end{array}$ & $\begin{array}{c}19.7 \\
1.33\end{array}$ \\
\hline 8405 & 06840500 & Dry Creek near Curtis, Nebraska & 403832 & 1002639 & 20.0 & $\begin{array}{l}21.4 \\
21.4\end{array}$ & $\begin{array}{c}5.60 \\
14.6\end{array}$ & $\begin{array}{l}172 \\
23.8\end{array}$ & $\begin{array}{l}1.67 \\
0.732\end{array}$ & $\begin{array}{r}2.35 \\
20.99\end{array}$ & $\begin{array}{l}0.20 \\
0.60\end{array}$ & $\begin{array}{l}0.094 \\
0.138\end{array}$ & $\begin{array}{c}20.3 \\
1.33\end{array}$ \\
\hline 8415 & 06841500 & Mitchell Creek above Harry Strunk Lake, Nebraska & 402819 & 1001524 & 52 & $\begin{array}{l}52.2 \\
52.2\end{array}$ & $\begin{array}{l}7.08 \\
9.66\end{array}$ & $\begin{array}{c}115 \\
13.6\end{array}$ & $\begin{array}{l}1.86 \\
0.787\end{array}$ & $\begin{array}{r}2.35 \\
21.05\end{array}$ & $\begin{array}{l}0.20 \\
0.59\end{array}$ & $\begin{array}{l}0.191 \\
0.118\end{array}$ & $\begin{array}{l}10.8 \\
1.36\end{array}$ \\
\hline 8440 & 06844000 & Muddy Creek at Arapahoe, Nebraska & 401819 & 995439 & 246 & $\begin{array}{l}242 \\
242\end{array}$ & $\begin{array}{l}3.94 \\
7.81\end{array}$ & $\begin{array}{l}149 \\
12.2\end{array}$ & $\begin{array}{l}1.64 \\
1.01\end{array}$ & $\begin{array}{r}2.35 \\
22.21\end{array}$ & $\begin{array}{l}0.20 \\
0.60\end{array}$ & $\begin{array}{l}0.198 \\
0.081\end{array}$ & $\begin{array}{c}17.8 \\
1.32\end{array}$ \\
\hline 8442a & 06844210 & Turkey Creek at Edison, Nebraska & 401614 & 994359 & 74.9 & $\begin{array}{l}74.6 \\
74.6\end{array}$ & $\begin{array}{l}8.55 \\
8.59\end{array}$ & $\begin{array}{c}113 \\
17.8\end{array}$ & $\begin{array}{l}1.93 \\
0.801\end{array}$ & $\begin{array}{r}2.45 \\
22.93\end{array}$ & $\begin{array}{l}0.20 \\
0.60\end{array}$ & $\begin{array}{l}0.201 \\
0.158\end{array}$ & $\begin{array}{c}16.0 \\
1.31\end{array}$ \\
\hline 8448 & 06844800 & South Fork Sappa Creek tributary near Goodland, Kansas & 391913 & 1013756 & 4.98 & $\begin{array}{l}4.68 \\
4.68\end{array}$ & $\begin{array}{c}0.50 \\
10.9\end{array}$ & $\begin{array}{r}33.5 \\
5.4\end{array}$ & $\begin{array}{l}1.45 \\
0.346\end{array}$ & $\begin{array}{r}2.25 \\
18.20\end{array}$ & $\begin{array}{l}0.21 \\
0.59\end{array}$ & $\begin{array}{l}0.214 \\
0.161\end{array}$ & $\begin{array}{l}2.4 \\
1.29\end{array}$ \\
\hline
\end{tabular}


Table B1. Selected drainage-basin characteristics for streamflow-gaging stations in Nebraska and for selected out-of-state stations--Continued

\begin{tabular}{|c|c|c|c|c|c|c|c|c|c|c|c|c|c|}
\hline \multirow[b]{2}{*}{$\underset{\substack{\text { Map } \\
\text { ber }}}{\operatorname{Map}}$} & \multirow[b]{2}{*}{$\begin{array}{l}\text { Station } \\
\text { number }\end{array}$} & \multirow[b]{2}{*}{ Station name-remarks } & \multirow[b]{2}{*}{$\begin{array}{c}\text { Latitude } \\
\left({ }^{0}, ”\right)\end{array}$} & \multirow[b]{2}{*}{$\begin{array}{c}\text { Longitude } \\
\left({ }^{0},{ }^{\prime \prime}\right)\end{array}$} & \multirow{2}{*}{$\begin{array}{c}\text { Published } \\
\text { total } \\
\text { drainage } \\
\text { area } \\
\left(\mathrm{mi}^{2}\right) \\
\end{array}$} & \multicolumn{8}{|c|}{ Drainage-basin characteristics } \\
\hline & & & & & & $\begin{array}{l}\text { TDA } \\
\text { CDA }\end{array}$ & $\begin{array}{l}\text { SF } \\
\text { RR }\end{array}$ & $\begin{array}{c}\text { BS } \\
\text { MCS }\end{array}$ & $\begin{array}{l}\text { CR } \\
\text { SD }\end{array}$ & $\begin{array}{l}\text { TTP } \\
\text { MAP }\end{array}$ & $\begin{array}{l}\text { AWC } \\
\text { PLP }\end{array}$ & $\begin{array}{l}\text { DF } \\
\text { SR }\end{array}$ & $\begin{array}{l}\text { MSS } \\
\text { P60 }\end{array}$ \\
\hline 8449 & 06844900 & South Fork Sappa Creek near Achilles, Kansas & 394036 & 1004318 & 446 & $\begin{array}{l}426 \\
378\end{array}$ & $\begin{array}{c}10.2 \\
6.82\end{array}$ & $\begin{array}{r}74.0 \\
9.4\end{array}$ & $\begin{array}{l}2.11 \\
0.942\end{array}$ & $\begin{array}{r}2.27 \\
18.87\end{array}$ & $\begin{array}{l}0.20 \\
0.59\end{array}$ & $\begin{array}{l}0.288 \\
0.127\end{array}$ & $\begin{array}{l}4.9 \\
1.29\end{array}$ \\
\hline 8450 & 06845000 & Sappa Creek near Oberlin, Kansas & 394707 & 1003427 & 1,086 & $\begin{array}{l}1,030 \\
1,030\end{array}$ & $\begin{array}{l}5.85 \\
6.61\end{array}$ & $\begin{array}{l}98.7 \\
10.8\end{array}$ & $\begin{array}{l}1.70 \\
0.841\end{array}$ & $\begin{array}{r}2.27 \\
19.68\end{array}$ & $\begin{array}{l}0.20 \\
0.60\end{array}$ & $\begin{array}{l}0.259 \\
0.109\end{array}$ & $\begin{array}{l}5.8 \\
1.31\end{array}$ \\
\hline 8451 & 06845100 & Long Branch Draw near Norcatur, Kansas & 395406 & 1001042 & 31.7 & $\begin{array}{l}30.9 \\
30.9\end{array}$ & $\begin{array}{r}3.12 \\
10.2\end{array}$ & $\begin{array}{l}85.9 \\
21.1\end{array}$ & $\begin{array}{l}1.36 \\
1.36\end{array}$ & $\begin{array}{r}2.35 \\
21.43\end{array}$ & $\begin{array}{l}0.20 \\
0.60\end{array}$ & $\begin{array}{l}0.614 \\
0.246\end{array}$ & $\begin{array}{c}10.4 \\
1.29\end{array}$ \\
\hline 8452 & 06845200 & Sappa Creek near Beaver City, Nebraska & $40 \quad 245$ & 995323 & 1,481 & $\begin{array}{l}1,480 \\
1,480\end{array}$ & $\begin{array}{l}8.78 \\
5.29\end{array}$ & $\begin{array}{l}112 \\
8.0\end{array}$ & $\begin{array}{l}2.26 \\
0.976\end{array}$ & $\begin{array}{r}2.30 \\
20.53\end{array}$ & $\begin{array}{l}0.20 \\
0.61\end{array}$ & $\begin{array}{l}0.313 \\
0.071\end{array}$ & $\begin{array}{l}7.5 \\
1.35\end{array}$ \\
\hline 8460 & 06846000 & Beaver Creek at Ludell, Kansas & 395054 & 1005729 & 1,411 & $\begin{array}{l}1,430 \\
1,430\end{array}$ & $\begin{array}{l}5.73 \\
7.22\end{array}$ & $\begin{array}{c}101 \\
10.0\end{array}$ & $\begin{array}{l}1.83 \\
0.686\end{array}$ & $\begin{array}{r}2.20 \\
18.29\end{array}$ & $\begin{array}{l}0.19 \\
0.57\end{array}$ & $\begin{array}{l}0.170 \\
0.099\end{array}$ & $\begin{array}{l}5.9 \\
1.29\end{array}$ \\
\hline 8462 & 06846200 & Beaver Creek tributary near Ludell, Kansas & 394852 & 1005218 & 10.2 & $\begin{array}{l}9.77 \\
9.77\end{array}$ & $\begin{array}{c}2.15 \\
14.0\end{array}$ & $\begin{array}{l}96.2 \\
33.8\end{array}$ & $\begin{array}{l}1.35 \\
1.11\end{array}$ & $\begin{array}{r}2.25 \\
21.58\end{array}$ & $\begin{array}{l}0.20 \\
0.58\end{array}$ & $\begin{array}{l}0.512 \\
0.352\end{array}$ & $\begin{array}{l}5.8 \\
1.27\end{array}$ \\
\hline 8465 & 06846500 & Beaver Creek at Cedar Bluffs, Kansas & 395906 & 1003334 & 1,618 & $\begin{array}{l}1,670 \\
1,320\end{array}$ & $\begin{array}{l}9.76 \\
6.74\end{array}$ & $\begin{array}{r}99.5 \\
9.6\end{array}$ & $\begin{array}{l}2.32 \\
0.976\end{array}$ & $\begin{array}{r}2.22 \\
18.81\end{array}$ & $\begin{array}{l}0.19 \\
0.57\end{array}$ & $\begin{array}{l}0.255 \\
0.097\end{array}$ & $\begin{array}{l}6.6 \\
1.29\end{array}$ \\
\hline 8470 & 06847000 & Beaver Creek near Beaver City, Nebraska & $4007 \quad 11$ & 995334 & 2,080 & $\begin{array}{l}2,080 \\
1,760\end{array}$ & $\begin{array}{c}12.9 \\
5.70\end{array}$ & $\begin{array}{r}107 \\
8.3\end{array}$ & $\begin{array}{l}2.73 \\
0.951\end{array}$ & $\begin{array}{r}2.24 \\
19.42\end{array}$ & $\begin{array}{l}0.20 \\
0.58\end{array}$ & $\begin{array}{l}0.250 \\
0.077\end{array}$ & $\begin{array}{l}7.3 \\
1.29\end{array}$ \\
\hline 8475 & 06847500 & Sappa Creek near Stamford, Nebraska & 400753 & 993315 & 3,840 & $\begin{array}{l}3,840 \\
3,370\end{array}$ & $\begin{array}{l}5.61 \\
5.48\end{array}$ & $\begin{array}{c}108 \\
7.1\end{array}$ & $\begin{array}{l}2.20 \\
1.01\end{array}$ & $\begin{array}{r}2.28 \\
20.14\end{array}$ & $\begin{array}{l}0.20 \\
0.59\end{array}$ & $\begin{array}{l}0.285 \\
0.066\end{array}$ & $\begin{array}{l}7.7 \\
1.31\end{array}$ \\
\hline 8476 & 06847600 & Prairie Dog Creek tributary at Colby, Kansas & 392327 & 1010243 & 7.53 & $\begin{array}{l}7.94 \\
7.94\end{array}$ & $\begin{array}{c}2.94 \\
10.4\end{array}$ & $\begin{array}{l}42.3 \\
19.2\end{array}$ & $\begin{array}{l}1.23 \\
0.716\end{array}$ & $\begin{array}{r}2.25 \\
19.14\end{array}$ & $\begin{array}{l}0.21 \\
0.59\end{array}$ & $\begin{array}{l}0.252 \\
0.453\end{array}$ & $\begin{array}{l}2.4 \\
1.29\end{array}$ \\
\hline 8479 & 06847900 & Prairie Dog Creek above Keith Sebelius Lake, Kansas & 394613 & 1000559 & 590 & $\begin{array}{l}583 \\
583\end{array}$ & $\begin{array}{l}9.69 \\
6.02\end{array}$ & $\begin{array}{r}90.2 \\
9.2\end{array}$ & $\begin{array}{l}2.09 \\
1.12\end{array}$ & $\begin{array}{r}2.33 \\
20.66\end{array}$ & $\begin{array}{l}0.20 \\
0.62\end{array}$ & $\begin{array}{l}0.350 \\
0.102\end{array}$ & $\begin{array}{l}8.0 \\
1.35\end{array}$ \\
\hline 8482 & 06848200 & Prairie Dog Creek tributary near Norton, Kansas & $3951 \quad 14$ & 995317 & 1.02 & $\begin{array}{l}1.09 \\
1.09\end{array}$ & $\begin{array}{l}3.09 \\
16.5\end{array}$ & $\begin{array}{l}82.6 \\
38.6\end{array}$ & $\begin{array}{l}1.24 \\
1.67\end{array}$ & $\begin{array}{r}2.45 \\
23.36\end{array}$ & $\begin{array}{l}0.20 \\
0.60\end{array}$ & $\begin{array}{l}0.920 \\
0.468\end{array}$ & $\begin{array}{c}10.4 \\
1.29\end{array}$ \\
\hline 8496 & 06849600 & Turkey Creek near Holdrege, Nebraska & 401933 & 992204 & 22.9 & $\begin{array}{l}22.6 \\
19.4\end{array}$ & $\begin{array}{l}2.75 \\
6.01\end{array}$ & $\begin{array}{l}34.3 \\
11.4\end{array}$ & $\begin{array}{l}1.50 \\
0.61\end{array}$ & $\begin{array}{r}2.45 \\
23.68\end{array}$ & $\begin{array}{l}0.20 \\
0.54\end{array}$ & $\begin{array}{l}0.103 \\
0.334\end{array}$ & $\begin{array}{l}6.3 \\
1.21\end{array}$ \\
\hline 8500 & 06850000 & Turkey Creek at Naponee, Nebraska & 400433 & 990816 & 129 & $\begin{array}{l}132 \\
125\end{array}$ & $\begin{array}{l}6.88 \\
5.72\end{array}$ & $\begin{array}{l}54.0 \\
12.2\end{array}$ & $\begin{array}{l}2.00 \\
0.836\end{array}$ & $\begin{array}{r}2.47 \\
23.37\end{array}$ & $\begin{array}{l}0.20 \\
0.58\end{array}$ & $\begin{array}{l}0.184 \\
0.226\end{array}$ & $\begin{array}{l}9.6 \\
1.27\end{array}$ \\
\hline 8502 & 06850200 & Cottonwood Creek near Bloomington, Nebraska & 400508 & 990356 & 15.6 & $\begin{array}{l}16.7 \\
16.7\end{array}$ & $\begin{array}{l}4.83 \\
10.4\end{array}$ & $\begin{array}{l}50.8 \\
26.1\end{array}$ & $\begin{array}{l}1.70 \\
0.960\end{array}$ & $\begin{array}{r}2.55 \\
24.32\end{array}$ & $\begin{array}{l}0.20 \\
0.59\end{array}$ & $\begin{array}{l}0.240 \\
0.513\end{array}$ & $\begin{array}{c}12.1 \\
1.31\end{array}$ \\
\hline 8510 & 06851000 & Center Creek at Franklin, Nebraska & 400611 & 985844 & 177 & $\begin{array}{r}180 \\
56\end{array}$ & $\begin{array}{l}9.15 \\
4.61\end{array}$ & $\begin{array}{l}32.1 \\
\underline{0.00}\end{array}$ & $\begin{array}{l}4.24 \\
1.12\end{array}$ & $\begin{array}{r}2.48 \\
24.34\end{array}$ & $\begin{array}{l}0.20 \\
0.48\end{array}$ & $\begin{array}{l}0.161 \\
0.373\end{array}$ & $\begin{array}{l}3.5 \\
1.14\end{array}$ \\
\hline 8511 & 06851100 & West Branch Thompson Creek at Hildreth, Nebraska & 402139 & 990140 & 63.9 & $\begin{array}{l}63.9 \\
18.4\end{array}$ & $\begin{array}{l}3.51 \\
2.82\end{array}$ & $\begin{array}{r}18.2 \\
4.4\end{array}$ & $\begin{array}{l}3.29 \\
0.836\end{array}$ & $\begin{array}{r}2.47 \\
24.08\end{array}$ & $\begin{array}{l}0.20 \\
0.46\end{array}$ & $\begin{array}{l}0.109 \\
0.239\end{array}$ & $\begin{array}{l}2.1 \\
1.11\end{array}$ \\
\hline 8512 & 06851200 & West Branch Thompson Creek near Hildreth, Nebraska & 402009 & 990016 & 110 & $\begin{array}{l}104 \\
27.0\end{array}$ & $\begin{array}{l}1.88 \\
2.72\end{array}$ & $\begin{array}{r}14.9 \\
4.4\end{array}$ & $\begin{array}{l}3.14 \\
0.868\end{array}$ & $\begin{array}{r}2.48 \\
24.44\end{array}$ & $\begin{array}{l}0.20 \\
0.48\end{array}$ & $\begin{array}{l}0.111 \\
0.297\end{array}$ & $\begin{array}{l}2.2 \\
1.15\end{array}$ \\
\hline 8513 & 06851300 & $\begin{array}{l}\text { West Branch Thompson Creek tributary near Hildreth, } \\
\text { Nebraska }\end{array}$ & $40 \quad 1909$ & $9900 \quad 02$ & 11.5 & $\begin{array}{c}11.5 \\
8.20\end{array}$ & $\begin{array}{l}0.89 \\
3.99\end{array}$ & $\begin{array}{r}16.4 \\
4.3\end{array}$ & $\begin{array}{l}1.62 \\
0.375\end{array}$ & $\begin{array}{r}2.55 \\
25.66\end{array}$ & $\begin{array}{l}0.20 \\
0.49\end{array}$ & $\begin{array}{l}0.122 \\
0.260\end{array}$ & $\begin{array}{l}2.3 \\
1.20\end{array}$ \\
\hline
\end{tabular}


Table B1. Selected drainage-basin characteristics for streamflow-gaging stations in Nebraska and for selected out-of-state stations--Continued

\begin{tabular}{|c|c|c|c|c|c|c|c|c|c|c|c|c|c|}
\hline $\begin{array}{c}\text { Map } \\
\text { num- } \\
\text { ber }\end{array}$ & $\begin{array}{l}\text { Station } \\
\text { number }\end{array}$ & Station name-remarks & $\begin{array}{c}\text { Latitude } \\
(0, \%)\end{array}$ & $\begin{array}{c}\text { Longitude } \\
(0, ")\end{array}$ & $\begin{array}{c}\text { Published } \\
\text { total } \\
\text { drainage } \\
\text { area } \\
\left(\mathrm{mi}^{2}\right)\end{array}$ & $\begin{array}{l}\text { TDA } \\
\text { CDA }\end{array}$ & $\begin{array}{l}\text { SF } \\
\text { RR }\end{array}$ & $\begin{array}{l}\text { BS } \\
\text { MCS }\end{array}$ & $\begin{array}{l}\text { CR } \\
\text { SD }\end{array}$ & $\begin{array}{l}\text { TTP } \\
\text { MAP }\end{array}$ & $\begin{array}{l}\text { AWC } \\
\text { PLP }\end{array}$ & $\begin{array}{l}\text { DF } \\
\text { SR }\end{array}$ & $\begin{array}{l}\text { MSS } \\
\text { P60 }\end{array}$ \\
\hline 8514 & 06851400 & West Branch Thompson Creek near Upland, Nebraska & 401731 & 985609 & 128 & $\begin{array}{l}147 \\
47.6\end{array}$ & $\begin{array}{l}3.56 \\
2.80\end{array}$ & $\begin{array}{r}15.4 \\
3.7\end{array}$ & $\begin{array}{l}2.78 \\
0.831\end{array}$ & $\begin{array}{r}2.50 \\
24.65\end{array}$ & $\begin{array}{l}0.20 \\
0.65\end{array}$ & $\begin{array}{l}0.105 \\
0.240\end{array}$ & $\begin{array}{l}2.8 \\
1.59\end{array}$ \\
\hline 8515 & 06851500 & Thompson Creek at Riverton, Nebraska & 400520 & 984538 & 290 & $\begin{array}{l}293 \\
197\end{array}$ & $\begin{array}{r}5.01 \\
4.35\end{array}$ & $\begin{array}{r}30.9 \\
7.5\end{array}$ & $\begin{array}{l}2.38 \\
0.700\end{array}$ & $\begin{array}{r}2.53 \\
25.14\end{array}$ & $\begin{array}{l}0.20 \\
0.71\end{array}$ & $\begin{array}{l}0.142 \\
0.242\end{array}$ & $\begin{array}{l}5.3 \\
1.69\end{array}$ \\
\hline 8531 & 06853100 & Beaver Creek near Rosemont, Nebraska & 401546 & 982230 & 0.75 & $\begin{array}{l}0.74 \\
0.74\end{array}$ & $\begin{array}{l}2.89 \\
8.75\end{array}$ & $\begin{array}{r}48.2 \\
9.3\end{array}$ & $\begin{array}{l}1.36 \\
1.93\end{array}$ & $\begin{array}{r}2.65 \\
26.15\end{array}$ & $\begin{array}{l}0.20 \\
0.53\end{array}$ & $\begin{array}{l}1.36 \\
0.192\end{array}$ & $\begin{array}{l}12.4 \\
1.19\end{array}$ \\
\hline 8538 & 06853800 & White Rock Creek near Burr Oak, Kansas & 395354 & 981505 & 227 & $\begin{array}{l}226 \\
226\end{array}$ & $\begin{array}{l}3.02 \\
5.60\end{array}$ & $\begin{array}{l}96.5 \\
10.9\end{array}$ & $\begin{array}{l}1.55 \\
0.910\end{array}$ & $\begin{array}{r}2.70 \\
26.83\end{array}$ & $\begin{array}{l}0.18 \\
0.49\end{array}$ & $\begin{array}{l}0.226 \\
0.112\end{array}$ & $\begin{array}{l}8.3 \\
1.17\end{array}$ \\
\hline 8561 & 06856100 & West Creek near Talmo, Kansas & 394000 & 973647 & 42.0 & $\begin{array}{l}40.5 \\
40.5\end{array}$ & $\begin{array}{l}7.96 \\
6.83\end{array}$ & $\begin{array}{l}75.6 \\
16.6\end{array}$ & $\begin{array}{l}1.79 \\
0.723\end{array}$ & $\begin{array}{r}2.95 \\
29.72\end{array}$ & $\begin{array}{l}0.17 \\
0.18\end{array}$ & $\begin{array}{l}0.148 \\
0.220\end{array}$ & $\begin{array}{l}6.8 \\
0.81\end{array}$ \\
\hline 8568 & 06856800 & Moll Creek near Green, Kansas & 392248 & 970027 & 3.60 & $\begin{array}{l}3.94 \\
3.94\end{array}$ & $\begin{array}{r}3.25 \\
10.4\end{array}$ & $\begin{array}{l}31.4 \\
18.0\end{array}$ & $\begin{array}{l}1.38 \\
1.14\end{array}$ & $\begin{array}{r}3.25 \\
30.48\end{array}$ & $\begin{array}{l}0.18 \\
0.17\end{array}$ & $\begin{array}{l}0.508 \\
0.572\end{array}$ & $\begin{array}{l}6.5 \\
0.74\end{array}$ \\
\hline 8710 & 06871000 & North Fork Solomon River at Glade, Kansas & 394040 & 991830 & 849 & $\begin{array}{l}938 \\
938\end{array}$ & $\begin{array}{l}16.1 \\
6.00\end{array}$ & ${ }_{9.4}^{133}$ & $\begin{array}{l}2.50 \\
0.983\end{array}$ & $\begin{array}{r}2.40 \\
21.22\end{array}$ & $\begin{array}{l}0.20 \\
0.59\end{array}$ & $\begin{array}{l}0.276 \\
0.071\end{array}$ & $\begin{array}{l}8.5 \\
1.30\end{array}$ \\
\hline 8715 & 06871500 & Bow Creek near Stockton, Kansas & 393346 & 991704 & 341 & $\begin{array}{l}340 \\
340\end{array}$ & $\begin{array}{c}22.7 \\
6.01\end{array}$ & ${ }_{9.2}^{114}$ & $\begin{array}{l}3.10 \\
1.13\end{array}$ & $\begin{array}{r}2.42 \\
21.25\end{array}$ & $\begin{array}{l}0.20 \\
0.63\end{array}$ & $\begin{array}{l}0.391 \\
0.081\end{array}$ & $\begin{array}{l}6.3 \\
1.43\end{array}$ \\
\hline 8726 & 06872600 & Oak Creek at Bellaire, Kansas & 394753 & 983959 & 4.75 & $\begin{array}{l}4.72 \\
4.72\end{array}$ & $\begin{array}{l}2.50 \\
18.0\end{array}$ & $\begin{array}{l}103 \\
42.5\end{array}$ & $\begin{array}{l}1.42 \\
0.719\end{array}$ & $\begin{array}{r}2.65 \\
24.15\end{array}$ & $\begin{array}{l}0.19 \\
0.42\end{array}$ & $\begin{array}{l}0.212 \\
0.411\end{array}$ & $\begin{array}{l}7.4 \\
1.11\end{array}$ \\
\hline 8730 & 06873000 & $\begin{array}{l}\text { South Fork Solomon River above Webster Reservoir, } \\
\text { Kansas }\end{array}$ & $3922 \quad 26$ & 993454 & 1,040 & $\begin{array}{l}1,040 \\
1,040\end{array}$ & $\begin{array}{l}9.85 \\
6.51\end{array}$ & $\begin{array}{c}114 \\
10.9\end{array}$ & $\begin{array}{l}2.19 \\
0.969\end{array}$ & $\begin{array}{r}2.39 \\
20.63\end{array}$ & $\begin{array}{l}0.19 \\
0.60\end{array}$ & $\begin{array}{l}0.253 \\
0.096\end{array}$ & $\begin{array}{l}7.5 \\
1.41\end{array}$ \\
\hline 8733 & 06873300 & Ash Creek tributary near Stockton, Kansas & $3926 \quad 15$ & 992216 & 0.89 & $\begin{array}{l}0.93 \\
0.93\end{array}$ & $\begin{array}{l}1.32 \\
26.0\end{array}$ & $\begin{array}{l}70.7 \\
58.9\end{array}$ & $\begin{array}{l}1.15 \\
1.20\end{array}$ & $\begin{array}{r}2.55 \\
22.91\end{array}$ & $\begin{array}{l}0.19 \\
0.38\end{array}$ & $\begin{array}{l}1.08 \\
0.833\end{array}$ & $\begin{array}{l}5.4 \\
1.12\end{array}$ \\
\hline 8735 & 06873500 & South Fork Solomon River at Alton, Kansas & 392733 & 985636 & 1,720 & $\begin{array}{l}1,670 \\
1,670\end{array}$ & $\begin{array}{c}11.5 \\
5.88\end{array}$ & $\begin{array}{l}116 \\
10.0\end{array}$ & $\begin{array}{l}2.29 \\
0.989\end{array}$ & $\begin{array}{r}2.44 \\
21.59\end{array}$ & $\begin{array}{l}0.18 \\
0.54\end{array}$ & $\begin{array}{l}0.262 \\
0.086\end{array}$ & $\begin{array}{l}7.5 \\
1.31\end{array}$ \\
\hline 8745 & 06874500 & East Limestone Creek near Ionia, Kansas & 394152 & 982019 & 25.6 & $\begin{array}{l}26.2 \\
26.2\end{array}$ & $\begin{array}{l}4.45 \\
9.98\end{array}$ & $\begin{array}{c}104 \\
17.8\end{array}$ & $\begin{array}{l}1.43 \\
1.08\end{array}$ & $\begin{array}{r}2.75 \\
27.76\end{array}$ & $\begin{array}{l}0.16 \\
0.38\end{array}$ & $\begin{array}{l}0.343 \\
0.170\end{array}$ & $\begin{array}{l}9.7 \\
1.02\end{array}$ \\
\hline 8799 & 06879900 & Big Blue River at Surprise, Nebraska & 410605 & 971835 & 345 & $\begin{array}{l}351 \\
351\end{array}$ & $\begin{array}{l}5.71 \\
2.11\end{array}$ & $\begin{array}{r}37.0 \\
4.6\end{array}$ & $\begin{array}{l}2.39 \\
0.746\end{array}$ & $\begin{array}{r}2.74 \\
27.67\end{array}$ & $\begin{array}{l}0.19 \\
0.35\end{array}$ & $\begin{array}{l}0.259 \\
0.124\end{array}$ & $\begin{array}{l}1.9 \\
0.95\end{array}$ \\
\hline 8800 & 06880000 & Lincoln Creek near Seward, Nebraska & 405457 & 970842 & 438 & $\begin{array}{l}438 \\
438\end{array}$ & $\begin{array}{l}7.60 \\
2.28\end{array}$ & $\begin{array}{r}38.3 \\
5.0\end{array}$ & $\begin{array}{l}2.74 \\
0.705\end{array}$ & $\begin{array}{r}2.77 \\
27.43\end{array}$ & $\begin{array}{l}0.18 \\
0.28\end{array}$ & $\begin{array}{l}0.198 \\
0.129\end{array}$ & $\begin{array}{l}2.3 \\
0.86\end{array}$ \\
\hline 8805 & 06880500 & Big Blue River at Seward, Nebraska & 405405 & 970554 & 1,107 & $\begin{array}{l}1,110 \\
1,110\end{array}$ & $\begin{array}{l}2.47 \\
1.96\end{array}$ & $\begin{array}{r}40.9 \\
4.8\end{array}$ & $\begin{array}{l}2.04 \\
0.716\end{array}$ & $\begin{array}{r}2.78 \\
27.86\end{array}$ & $\begin{array}{l}0.18 \\
0.30\end{array}$ & $\begin{array}{l}0.221 \\
0.116\end{array}$ & $\begin{array}{l}2.2 \\
0.88\end{array}$ \\
\hline 8805b & 06880508 & Plum Creek near Seward, Nebraska & 405549 & 970431 & 85.5 & $\begin{array}{l}85.4 \\
85.4\end{array}$ & $\begin{array}{l}4.38 \\
4.14\end{array}$ & $\begin{array}{r}72.6 \\
8.3\end{array}$ & $\begin{array}{l}1.69 \\
0.948\end{array}$ & $\begin{array}{r}2.86 \\
27.85\end{array}$ & $\begin{array}{l}0.18 \\
0.25\end{array}$ & $\begin{array}{l}0.304 \\
0.115\end{array}$ & $\begin{array}{l}2.4 \\
0.81\end{array}$ \\
\hline $8805 \mathrm{c}$ & 06880590 & $\begin{array}{l}\text { North Branch West Fork Big Blue River tributary at Giltner, } \\
\text { Nebraska }\end{array}$ & 404703 & 980856 & 7.52 & $\begin{array}{l}7.24 \\
5.08\end{array}$ & $\begin{array}{l}5.38 \\
3.14\end{array}$ & $\begin{array}{r}16.0 \\
9.7\end{array}$ & $\begin{array}{l}2.74 \\
1.16\end{array}$ & $\begin{array}{r}2.65 \\
26.66\end{array}$ & $\begin{array}{l}0.18 \\
0.19\end{array}$ & $\begin{array}{l}0.197 \\
0.607\end{array}$ & 2.0 \\
\hline 8807a & 06880710 & School Creek tributary near Harvard, Nebraska & 403459 & 980359 & 13.1 & $\begin{array}{l}13.6 \\
13.6\end{array}$ & $\begin{array}{l}1.85 \\
3.39\end{array}$ & $\begin{array}{r}11.1 \\
5.7\end{array}$ & $\begin{array}{l}1.48 \\
0.395\end{array}$ & $\begin{array}{r}2.73 \\
27.36\end{array}$ & $\begin{array}{l}0.18 \\
0.13\end{array}$ & $\begin{array}{l}0.073 \\
0.515\end{array}$ & $\begin{array}{l}3.4 \\
0.75\end{array}$ \\
\hline
\end{tabular}


Table B1. Selected drainage-basin characteristics for streamflow-gaging stations in Nebraska and for selected out-of-state stations--Continued

\begin{tabular}{|c|c|c|c|c|c|c|c|c|c|c|c|c|c|}
\hline \multirow[b]{2}{*}{$\underset{\substack{\text { Map } \\
\text { ber }}}{\operatorname{Map}}$} & \multirow[b]{2}{*}{$\begin{array}{l}\text { Station } \\
\text { number }\end{array}$} & \multirow[b]{2}{*}{ Station name-remarks } & \multirow[b]{2}{*}{$\begin{array}{c}\text { Latitude } \\
\left({ }^{0}, ”\right)\end{array}$} & \multirow[b]{2}{*}{$\begin{array}{c}\text { Longitude } \\
(0, ")\end{array}$} & \multirow{2}{*}{$\begin{array}{c}\text { Published } \\
\text { total } \\
\text { drainage } \\
\text { area } \\
\left(\mathrm{mi}^{2}\right) \\
\end{array}$} & \multicolumn{8}{|c|}{ Drainage-basin characteristics } \\
\hline & & & & & & $\begin{array}{l}\text { TDA } \\
\text { CDA }\end{array}$ & $\begin{array}{l}\text { SF } \\
\text { RR }\end{array}$ & $\begin{array}{l}\text { BS } \\
\text { MCS }\end{array}$ & $\begin{array}{l}\text { CR } \\
\text { SD }\end{array}$ & $\begin{array}{l}\text { TTP } \\
\text { MAP }\end{array}$ & $\begin{array}{l}\text { AWC } \\
\text { PLP }\end{array}$ & $\begin{array}{l}\text { DF } \\
\text { SR }\end{array}$ & $\begin{array}{l}\text { MSS } \\
\text { P60 }\end{array}$ \\
\hline $8807 \mathrm{~b}$ & 06880720 & School Creek near Harvard, Nebraska & 403548 & 980304 & 51.5 & $\begin{array}{l}49.6 \\
49.6\end{array}$ & $\begin{array}{l}0.96 \\
2.96\end{array}$ & $\begin{array}{r}12.9 \\
8.7\end{array}$ & $\begin{array}{l}1.42 \\
0.284\end{array}$ & $\begin{array}{r}2.70 \\
27.47\end{array}$ & $\begin{array}{l}0.18 \\
0.15\end{array}$ & $\begin{array}{l}0.060 \\
0.673\end{array}$ & $\begin{array}{l}2.9 \\
0.73\end{array}$ \\
\hline $8807 \mathrm{c}$ & 06880730 & School Creek tributary \#2 near Harvard, Nebraska & 403641 & 980235 & 16.4 & $\begin{array}{l}16.5 \\
16.5\end{array}$ & $\begin{array}{l}0.50 \\
3.45\end{array}$ & $\begin{array}{l}13.8 \\
11.5\end{array}$ & $\begin{array}{l}1.39 \\
0.184\end{array}$ & $\begin{array}{r}2.72 \\
27.33\end{array}$ & $\begin{array}{l}0.18 \\
0.17\end{array}$ & $\begin{array}{l}0.061 \\
0.831\end{array}$ & $\begin{array}{l}2.5 \\
0.72\end{array}$ \\
\hline $8807 \mathrm{~d}$ & 06880740 & School Creek near Saronville, Nebraska & 403458 & 975724 & 89.4 & $\begin{array}{l}87.0 \\
87.0\end{array}$ & $\begin{array}{l}1.89 \\
2.74\end{array}$ & $\begin{array}{r}17.3 \\
7.1\end{array}$ & $\begin{array}{l}1.59 \\
0.385\end{array}$ & $\begin{array}{r}2.72 \\
27.33\end{array}$ & $\begin{array}{l}0.18 \\
0.16\end{array}$ & $\begin{array}{l}0.080 \\
0.408\end{array}$ & $\begin{array}{l}2.8 \\
0.73\end{array}$ \\
\hline 8808 & 06880800 & West Fork Big Blue River near Dorchester, Nebraska & 404351 & 971038 & 1,192 & $\begin{array}{l}1,190 \\
1,190\end{array}$ & $\begin{array}{l}4.05 \\
2.40\end{array}$ & $\begin{array}{r}43.9 \\
5.2\end{array}$ & $\begin{array}{l}2.06 \\
0.614\end{array}$ & $\begin{array}{r}2.75 \\
27.30\end{array}$ & $\begin{array}{l}0.18 \\
0.25\end{array}$ & $\begin{array}{l}0.139 \\
0.118\end{array}$ & $\begin{array}{l}2.6 \\
0.83\end{array}$ \\
\hline 8810 & 06881000 & Big Blue River near Crete, Nebraska & 403547 & 965735 & 2,710 & $\begin{array}{l}2,710 \\
2,710\end{array}$ & $\begin{array}{l}2.31 \\
2.07\end{array}$ & $\begin{array}{r}52.0 \\
4.8\end{array}$ & $\begin{array}{l}1.79 \\
0.690\end{array}$ & $\begin{array}{r}2.78 \\
27.65\end{array}$ & $\begin{array}{l}0.18 \\
0.27\end{array}$ & $\begin{array}{l}0.185 \\
0.092\end{array}$ & $\begin{array}{l}2.6 \\
0.85\end{array}$ \\
\hline 8812 & 06881200 & Turkey Creek near Wilber, Nebraska & 402848 & 970043 & 461 & $\begin{array}{l}461 \\
461\end{array}$ & $\begin{array}{l}5.68 \\
2.87\end{array}$ & $\begin{array}{r}40.5 \\
5.2\end{array}$ & $\begin{array}{l}2.07 \\
0.633\end{array}$ & $\begin{array}{r}2.87 \\
28.61\end{array}$ & $\begin{array}{l}0.19 \\
0.22\end{array}$ & $\begin{array}{l}0.128 \\
0.129\end{array}$ & $\begin{array}{l}5.5 \\
0.86\end{array}$ \\
\hline 8814a & 06881450 & Indian Creek at Beatrice, Nebraska & 401707 & 964446 & 74.7 & $\begin{array}{l}74.5 \\
74.5\end{array}$ & $\begin{array}{l}4.14 \\
5.06\end{array}$ & $\begin{array}{r}69.0 \\
7.6\end{array}$ & $\begin{array}{l}1.61 \\
0.805\end{array}$ & $\begin{array}{r}3.05 \\
30.23\end{array}$ & $\begin{array}{l}0.17 \\
0.18\end{array}$ & $\begin{array}{l}0.228 \\
0.111\end{array}$ & $\begin{array}{l}5.5 \\
0.56\end{array}$ \\
\hline 8815 & 06881500 & Big Blue River at Beatrice, Nebraska & 401500 & 964500 & 3,900 & $\begin{array}{l}3,890 \\
3,830\end{array}$ & $\begin{array}{l}2.77 \\
1.92\end{array}$ & $\begin{array}{r}59.0 \\
4.1\end{array}$ & $\begin{array}{l}1.84 \\
0.730\end{array}$ & $\begin{array}{r}2.83 \\
28.08\end{array}$ & $\begin{array}{l}0.18 \\
0.26\end{array}$ & $\begin{array}{l}0.189 \\
0.069\end{array}$ & $\begin{array}{l}3.6 \\
0.84\end{array}$ \\
\hline 8820 & 06882000 & Big Blue River at Barneston, Nebraska & $40 \quad 3 \quad 10$ & 963516 & 4,447 & $\begin{array}{l}4,450 \\
4,370\end{array}$ & $\begin{array}{l}3.30 \\
1.82\end{array}$ & $\begin{array}{r}66.2 \\
3.8\end{array}$ & $\begin{array}{l}1.96 \\
0.765\end{array}$ & $\begin{array}{r}2.87 \\
28.52\end{array}$ & $\begin{array}{l}0.18 \\
0.25\end{array}$ & $\begin{array}{l}0.208 \\
0.057\end{array}$ & $\begin{array}{l}3.9 \\
0.81\end{array}$ \\
\hline 8830 & 06883000 & Little Blue River near Deweese, Nebraska & 401958 & 980359 & 979 & $\begin{array}{l}984 \\
984\end{array}$ & $\begin{array}{l}2.39 \\
3.02\end{array}$ & $\begin{array}{r}29.3 \\
6.4\end{array}$ & $\begin{array}{l}1.66 \\
0.694\end{array}$ & $\begin{array}{r}2.62 \\
26.27\end{array}$ & $\begin{array}{l}0.19 \\
0.66\end{array}$ & $\begin{array}{l}0.131 \\
0.218\end{array}$ & $\begin{array}{l}5.6 \\
1.61\end{array}$ \\
\hline 8835a & 06883540 & Spring Creek tributary near Ruskin, Nebraska & 400649 & 974912 & 2.11 & $\begin{array}{l}2.03 \\
2.03\end{array}$ & $\begin{array}{l}2.69 \\
6.53\end{array}$ & $\begin{array}{r}32.8 \\
5.4\end{array}$ & $\begin{array}{l}1.49 \\
1.19\end{array}$ & $\begin{array}{r}2.85 \\
27.73\end{array}$ & $\begin{array}{l}0.18 \\
0.14\end{array}$ & $\begin{array}{l}0.493 \\
0.165\end{array}$ & $\begin{array}{l}2.7 \\
0.72\end{array}$ \\
\hline 8835b & 06883570 & Little Blue River near Alexandria (Gilead), Nebraska & 401227 & 972326 & 1,560 & $\begin{array}{l}1,560 \\
1,560\end{array}$ & $\begin{array}{l}5.28 \\
2.75\end{array}$ & $\begin{array}{r}44.6 \\
6.3\end{array}$ & $\begin{array}{l}2.14 \\
0.793\end{array}$ & $\begin{array}{r}2.69 \\
26.91\end{array}$ & $\begin{array}{l}0.19 \\
0.53\end{array}$ & $\begin{array}{l}0.193 \\
0.141\end{array}$ & $\begin{array}{l}6.3 \\
1.55\end{array}$ \\
\hline 8836 & 06883600 & South Fork Big Sandy Creek near Edgar, Nebraska & 402009 & 975819 & 10.3 & $\begin{array}{l}10.2 \\
10.2\end{array}$ & $\begin{array}{l}0.13 \\
2.90\end{array}$ & $\begin{array}{r}16.8 \\
3.1\end{array}$ & $\begin{array}{l}1.30 \\
0.138\end{array}$ & $\begin{array}{r}2.75 \\
26.61\end{array}$ & $\begin{array}{l}0.19 \\
0.12\end{array}$ & $\begin{array}{l}0.098 \\
0.186\end{array}$ & $\begin{array}{l}3.7 \\
0.77\end{array}$ \\
\hline 8837 & 06883700 & South Fork Big Sandy Creek near Davenport, Nebraska & 401826 & 975239 & 28.1 & $\begin{array}{l}28.3 \\
28.3\end{array}$ & $\begin{array}{l}2.05 \\
5.84\end{array}$ & $\begin{array}{l}36.2 \\
10.0\end{array}$ & $\begin{array}{l}1.46 \\
0.529\end{array}$ & $\begin{array}{r}2.75 \\
26.61\end{array}$ & $\begin{array}{l}0.19 \\
0.12\end{array}$ & $\begin{array}{l}0.212 \\
0.276\end{array}$ & $\begin{array}{l}3.6 \\
0.76\end{array}$ \\
\hline 8838 & 06883800 & South Fork Big Sandy Creek near Carleton, Nebraska & 401548 & 974748 & 50.4 & $\begin{array}{l}49.9 \\
49.9\end{array}$ & $\begin{array}{l}3.41 \\
3.31\end{array}$ & $\begin{array}{r}27.5 \\
7.6\end{array}$ & $\begin{array}{l}1.70 \\
0.572\end{array}$ & $\begin{array}{r}2.79 \\
26.74\end{array}$ & $\begin{array}{l}0.19 \\
0.13\end{array}$ & $\begin{array}{l}0.120 \\
0.278\end{array}$ & $\begin{array}{l}3.8 \\
0.77\end{array}$ \\
\hline 8839 & 06883900 & South Fork Big Sandy Creek near Hebron, Nebraska & $4013 \quad 40$ & 973434 & 90.3 & $\begin{array}{l}103 \\
103\end{array}$ & $\begin{array}{l}5.95 \\
3.02\end{array}$ & $\begin{array}{r}30.2 \\
5.8\end{array}$ & $\begin{array}{l}2.68 \\
0.505\end{array}$ & $\begin{array}{r}2.81 \\
27.50\end{array}$ & $\begin{array}{l}0.19 \\
0.17\end{array}$ & $\begin{array}{l}0.116 \\
0.192\end{array}$ & $\begin{array}{l}4.4 \\
0.82\end{array}$ \\
\hline 8839b & 06883940 & Big Sandy Creek at Alexandria, Nebraska & 40146 & 972320 & 607 & $\begin{array}{l}617 \\
617\end{array}$ & $\begin{array}{l}4.03 \\
0.86\end{array}$ & $\begin{array}{l}6.9 \\
2.0\end{array}$ & $\begin{array}{l}1.91 \\
0.526\end{array}$ & $\begin{array}{r}2.81 \\
27.96\end{array}$ & $\begin{array}{l}0.18 \\
0.20\end{array}$ & $\begin{array}{l}0.107 \\
0.283\end{array}$ & $\begin{array}{l}5.0 \\
1.10\end{array}$ \\
\hline $8839 \mathrm{c}$ & 06883955 & Little Sandy Creek near Ohiowa, Nebraska & 402536 & 972338 & 11.6 & $\begin{array}{l}11.3 \\
11.3\end{array}$ & $\begin{array}{l}1.47 \\
6.30\end{array}$ & $\begin{array}{l}40.6 \\
18.6\end{array}$ & $\begin{array}{l}1.23 \\
0.485\end{array}$ & $\begin{array}{r}2.86 \\
28.96\end{array}$ & $\begin{array}{l}0.19 \\
0.17\end{array}$ & $\begin{array}{l}0.177 \\
0.458\end{array}$ & $\begin{array}{l}5.2 \\
0.80\end{array}$ \\
\hline 8840 & 06884000 & Little Blue River near Fairbury, Nebraska & 400653 & $97 \quad 1012$ & 2,350 & $\begin{array}{l}2,360 \\
2,360\end{array}$ & $\begin{array}{l}4.26 \\
2.60\end{array}$ & $\begin{array}{r}47.9 \\
6.0\end{array}$ & $\begin{array}{l}2.02 \\
0.728\end{array}$ & $\begin{array}{r}2.74 \\
27.38\end{array}$ & $\begin{array}{l}0.19 \\
0.43\end{array}$ & $\begin{array}{l}0.170 \\
0.126\end{array}$ & $\begin{array}{l}6.1 \\
1.43\end{array}$ \\
\hline
\end{tabular}


Table B1. Selected drainage-basin characteristics for streamflow-gaging stations in Nebraska and for selected out-of-state stations--Continued

\begin{tabular}{|c|c|c|c|c|c|c|c|c|c|c|c|c|c|c|}
\hline \multirow{2}{*}{\multicolumn{2}{|c|}{ 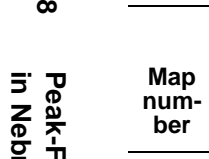 }} & \multirow[b]{2}{*}{$\begin{array}{l}\text { Station } \\
\text { number }\end{array}$} & \multirow[b]{2}{*}{ Station name-remarks } & \multirow[b]{2}{*}{$\begin{array}{l}\text { Latitude } \\
\left({ }^{(},, "\right)\end{array}$} & \multirow[b]{2}{*}{$\begin{array}{c}\text { Longitude } \\
\left({ }^{0},{ }^{\prime}\right)\end{array}$} & \multirow{2}{*}{$\begin{array}{c}\text { Published } \\
\text { total } \\
\text { drainage } \\
\text { area } \\
\left(\mathrm{mi}^{2}\right)\end{array}$} & \multicolumn{8}{|c|}{ Drainage-basin characteristics } \\
\hline & & & & & & & $\begin{array}{l}\text { TDA } \\
\text { CDA }\end{array}$ & $\begin{array}{l}\text { SF } \\
\text { RR }\end{array}$ & $\begin{array}{c}\text { BS } \\
\text { MCS }\end{array}$ & $\begin{array}{l}\text { CR } \\
\text { SD }\end{array}$ & $\begin{array}{l}\text { TTP } \\
\text { MAP }\end{array}$ & $\begin{array}{l}\text { AWC } \\
\text { PLP }\end{array}$ & $\begin{array}{l}\text { DF } \\
\text { SR }\end{array}$ & $\begin{array}{c}\text { MSS } \\
\text { P60 }\end{array}$ \\
\hline$\frac{D}{i} \frac{\Sigma}{\frac{\pi}{D}}$ & $8840 \mathrm{~b}$ & 06884005 & Dry Branch tributary near Fairbury, Nebraska & 400243 & 971014 & 4.51 & $\begin{array}{l}4.50 \\
4.50\end{array}$ & $\begin{array}{c}2.59 \\
18.6\end{array}$ & $\begin{array}{c}162 \\
55.1\end{array}$ & $\begin{array}{l}1.43 \\
1.39\end{array}$ & $\begin{array}{r}3.05 \\
30.33\end{array}$ & $\begin{array}{l}0.13 \\
0.14\end{array}$ & $\begin{array}{l}0.889 \\
0.341\end{array}$ & $\begin{array}{l}9.2 \\
0.58\end{array}$ \\
\hline 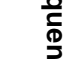 & 8842 & 06884200 & Mill Creek at Washington, Kansas & 394850 & $9702 \quad 20$ & 344 & $\begin{array}{r}345 \\
34\end{array}$ & $\begin{array}{l}2.89 \\
4.05\end{array}$ & $\begin{array}{r}99.1 \\
8.0\end{array}$ & $\begin{array}{l}1.47 \\
0.951\end{array}$ & $\begin{array}{r}3.03 \\
30.92\end{array}$ & $\begin{array}{l}0.16 \\
0.19\end{array}$ & $\begin{array}{l}0.229 \\
0.081\end{array}$ & $\begin{array}{l}6.8 \\
0.75\end{array}$ \\
\hline 夰 & 8843 & 06884300 & Mill Creek tributary near Washington, Kansas & $3948 \quad 47$ & 970029 & 3.20 & $\begin{array}{l}3.17 \\
3.17\end{array}$ & $\begin{array}{l}1.36 \\
19.8\end{array}$ & $\begin{array}{l}111 \\
48.5\end{array}$ & $\begin{array}{l}1.21 \\
0.654\end{array}$ & $\begin{array}{r}3.15 \\
31.80\end{array}$ & $\begin{array}{l}0.14 \\
0.16\end{array}$ & $\begin{array}{l}0.315 \\
0.439\end{array}$ & $\begin{array}{l}9.6 \\
0.62\end{array}$ \\
\hline$\stackrel{0}{\frac{0}{0}}$ & 8844 & 06884400 & Little Blue River near Barnes, Kansas & 394632 & 965129 & 3,324 & $\begin{array}{l}3,290 \\
3,290\end{array}$ & $\begin{array}{l}4.86 \\
2.95\end{array}$ & $\begin{array}{r}78.5 \\
5.6\end{array}$ & $\begin{array}{l}1.75 \\
0.838\end{array}$ & $\begin{array}{r}2.83 \\
28.35\end{array}$ & $\begin{array}{l}0.18 \\
0.36\end{array}$ & $\begin{array}{l}0.217 \\
0.071\end{array}$ & $\begin{array}{l}6.4 \\
1.25\end{array}$ \\
\hline $\begin{array}{l}\infty \\
\stackrel{0}{2}\end{array}$ & 8855 & 06885500 & Black Vermillion River near Frankfort, Kansas & 39413 & 962615 & 410 & $\begin{array}{l}410 \\
410\end{array}$ & $\begin{array}{l}1.05 \\
3.73\end{array}$ & $\begin{array}{c}103 \\
7.4\end{array}$ & $\begin{array}{l}1.51 \\
0.980\end{array}$ & $\begin{array}{r}3.27 \\
33.13\end{array}$ & $\begin{array}{l}0.15 \\
0.12\end{array}$ & $\begin{array}{l}0.266 \\
0.072\end{array}$ & $\begin{array}{l}6.0 \\
0.35\end{array}$ \\
\hline$\underset{\Phi}{m}$ & 8865 & 06886500 & Fancy Creek at Winkler, Kansas & 392819 & 964954 & 174 & $\begin{array}{l}174 \\
174\end{array}$ & $\begin{array}{l}2.17 \\
6.25\end{array}$ & $\begin{array}{c}110 \\
10.3\end{array}$ & $\begin{array}{l}1.25 \\
0.787\end{array}$ & $\begin{array}{r}3.19 \\
30.77\end{array}$ & $\begin{array}{l}0.14 \\
0.11\end{array}$ & $\begin{array}{l}0.196 \\
0.094\end{array}$ & $\begin{array}{l}7.0 \\
0.53\end{array}$ \\
\hline 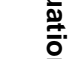 & 8872 & 06887200 & Cedar Creek near Manhattan, Kansas & 391530 & 963347 & 13.4 & $\begin{array}{l}14.7 \\
14.7\end{array}$ & $\begin{array}{l}2.66 \\
22.2\end{array}$ & $\begin{array}{l}235 \\
43.9\end{array}$ & $\begin{array}{l}1.24 \\
1.18\end{array}$ & $\begin{array}{r}3.35 \\
31.71\end{array}$ & $\begin{array}{l}0.11 \\
0.08\end{array}$ & $\begin{array}{l}0.611 \\
0.186\end{array}$ & $\begin{array}{c}14.5 \\
0.31\end{array}$ \\
\hline$\stackrel{\circ}{\stackrel{0}{\rightleftarrows}}$ & 8880 & 06888000 & Vermillion Creek near Wamego, Kansas & 392059 & 961309 & 243 & $\begin{array}{l}240 \\
240\end{array}$ & $\begin{array}{l}3.15 \\
6.86\end{array}$ & $\begin{array}{l}149 \\
9.0\end{array}$ & $\begin{array}{l}1.45 \\
0.900\end{array}$ & $\begin{array}{r}3.35 \\
35.28\end{array}$ & $\begin{array}{l}0.13 \\
0.12\end{array}$ & $\begin{array}{l}0.241 \\
0.061\end{array}$ & $\begin{array}{c}10.0 \\
0.36\end{array}$ \\
\hline $\begin{array}{l}\overline{0} \\
0 \\
0\end{array}$ & 8883 & 06888300 & Rock Creek near Louisville, Kansas & 391553 & 962247 & 128 & $\begin{array}{l}136 \\
136\end{array}$ & $\begin{array}{l}3.01 \\
9.05\end{array}$ & $\begin{array}{c}163 \\
17.1\end{array}$ & $\begin{array}{l}1.39 \\
0.794\end{array}$ & $\begin{array}{r}3.35 \\
33.75\end{array}$ & $\begin{array}{l}0.12 \\
0.15\end{array}$ & $\begin{array}{l}0.192 \\
0.104\end{array}$ & $\begin{array}{c}11.4 \\
0.48\end{array}$ \\
\hline
\end{tabular}


Table B2. Peak-flow frequency data for streamflow-gaging stations in Nebraska and for selected out-of-state stations, and drainage areas for regulated streams [BB, Big Blue River Basin; Br, Branch; C\&SC, Central and South-Central; CR, continuous record; Cr, Creek; Fk, Fork; HPC, High-Permeability—Composite; HPS, High-Permeability—Standard; LP3S, log-pearson Type III with station skew; LP3W, log-Pearson Type III with weighted skew; N, North; NE, Northeast; N\&W, Northern and Western; PS, peak stage; R, River; REG, regulated; S, South; $\mathrm{SE}$, Southeast; TDA, total drainage area; trib, tributary; UR, upper Republican River; W, West; WY, water year; $\mathrm{ft}^{3} / \mathrm{s}$, cubic feet per second; $\mathrm{mi}^{2}$, square miles; >, greater than; <, less than; \#, number; drainage areas for regulated streams from Boohar and Provaznik (1996) except as noted. Note: values of generalized skew and peak discharge computed from regression equations might not agree with values in table for stations used in the development of the respective equations because table values for those stations are based on the regression analyses, which used unrounded values of drainage-basin characteristics and equation coefficients]

\begin{tabular}{|c|c|c|c|c|c|c|c|c|c|c|c|c|c|c|c|}
\hline \multirow{2}{*}{$\begin{array}{c}\begin{array}{c}\text { Map } \\
\text { num- } \\
\text { ber }\end{array} \\
3822\end{array}$} & \multirow{2}{*}{$\begin{array}{c}\begin{array}{c}\text { Station } \\
\text { number }\end{array} \\
06382200\end{array}$} & \multirow{2}{*}{$\begin{array}{l}\begin{array}{c}\text { Station name } \\
\text { (station skew-skew relations }\end{array} \\
\text { skew-peak-flow regional equations or remarks) }\end{array}$} & \multirow{2}{*}{$\begin{array}{c}\begin{array}{c}\text { Gage } \\
\text { type }\end{array} \\
\text { PS }\end{array}$} & \multicolumn{8}{|c|}{$\begin{array}{l}\text { Peak discharge }\left(\mathrm{ft}^{3} / \mathrm{s}\right) \text { for given recurrence interval (years) } \\
\text { and/or remarks }\end{array}$} & \multirow{2}{*}{$\begin{array}{c}\begin{array}{c}\text { Type and length } \\
\text { (years) of analysis } \\
\text {-regional } \\
\text { equation- }\end{array} \\
\text { LP3W 18 } \\
\text {-N\&W- }\end{array}$} & \multirow{2}{*}{$\begin{array}{c}\begin{array}{c}\text { Period of } \\
\text { peak-flow } \\
\text { record }\end{array} \\
1964-81\end{array}$} & \multicolumn{2}{|c|}{$\begin{array}{l}\text { WY and dis- } \\
\text { charge }\left(\mathrm{ft}^{3} / \mathrm{s}\right) \\
\text { of maximum } \\
\text { peak }\end{array}$} \\
\hline & & & & $\begin{array}{l}674 \\
105\end{array}$ & $\begin{array}{r}1,640 \\
467\end{array}$ & $\begin{array}{r}2,500 \\
866\end{array}$ & $\begin{array}{l}3,820 \\
1,510\end{array}$ & $\begin{array}{l}4,940 \\
2,080\end{array}$ & $\begin{array}{l}6,160 \\
1,730\end{array}$ & $\begin{array}{l}7,480 \\
2,310\end{array}$ & $\begin{array}{l}9,350 \\
3,240\end{array}$ & & & 1968 & 4,050 \\
\hline 3962 & 06396200 & $\begin{array}{l}\text { Fiddle Cr near Edgemont, S. Dak. } \\
\begin{array}{l}(-0.415-\text { Skew map, N\&W } \\
-0.259-N \& W)\end{array}\end{array}$ & PS & $\begin{array}{r}16 \\
7\end{array}$ & $\begin{array}{l}48 \\
36\end{array}$ & $\begin{array}{l}82 \\
79\end{array}$ & $\begin{array}{l}143 \\
175\end{array}$ & $\begin{array}{l}202 \\
285\end{array}$ & $\begin{array}{l}272 \\
660\end{array}$ & $\begin{array}{l}355 \\
889\end{array}$ & $\begin{array}{r}486 \\
1,260\end{array}$ & $\begin{array}{l}\mathrm{LP} 3 \mathrm{~W} \\
-\mathrm{N} \& \mathrm{~W}-\end{array}$ & $1956-80$ & 1980 & 275 \\
\hline 3963 & 06396300 & $\begin{array}{l}\text { Cottonwood Cr trib near Edgemont, S. Dak. } \\
(-0.238-\text { Skew map, N\&W }\end{array}$ & PS & 23 & ${ }^{42} T D$ & $<1 \mathrm{mi}^{2}$ & $\begin{array}{c}74 \\
\text { Basin ch }\end{array}$ & $\begin{array}{c}89 \\
\text { acteristic }\end{array}$ & $\begin{array}{l}103 \\
\text { s incompl }\end{array}$ & lete 117 & 137 & LP3W 25 & $1956-80$ & 1965 & 86 \\
\hline $3964 a$ & 06396490 & $\begin{array}{l}\text { Warbonnet Cr near Harrison, Nebr. } \\
(-0.210 \text { - New station for N\&W network analysis) }\end{array}$ & PS & $\begin{array}{r}59 \\
100\end{array}$ & $\begin{array}{l}133 \\
322\end{array}$ & $\begin{array}{l}200 \\
693\end{array}$ & $\begin{array}{r}303 \\
1,280\end{array}$ & $\begin{array}{r}394 \\
1,890\end{array}$ & $\begin{array}{r}496 \\
5,960\end{array}$ & $\begin{array}{r}610 \\
8,330\end{array}$ & $\begin{array}{r}779 \\
12,200\end{array}$ & $\begin{array}{l}\mathrm{LP} 3 \mathrm{~W} 10 \\
-\mathrm{N} \& \mathrm{~W}-\end{array}$ & 1969-78 & 1969 & 270 \\
\hline 3997 & 06399700 & $\begin{array}{l}\text { Pine Cr near Ardmore, S. Dak. } \\
(-0.319-\text { Skew map }-0.378-N \& W)\end{array}$ & PS & $\begin{array}{l}849 \\
129\end{array}$ & $\begin{array}{r}1,190 \\
594\end{array}$ & $\begin{array}{l}1,390 \\
1,120\end{array}$ & $\begin{array}{l}1,630 \\
1,960\end{array}$ & $\begin{array}{l}1,800 \\
2,700\end{array}$ & $\begin{array}{l}1,950 \\
1,880\end{array}$ & $\begin{array}{l}2,100 \\
2,550\end{array}$ & $\begin{array}{l}2,290 \\
3,640\end{array}$ & $\begin{array}{l}\mathrm{LP} 3 \mathrm{~W} 19 \\
-\mathrm{N} \& \mathrm{~W}-\end{array}$ & $1956-74$ & 1968 & 1,550 \\
\hline 4000 & 06400000 & $\begin{array}{l}\text { t, S. Dak. } \\
\text { N\&W }-0.163-N \& W)\end{array}$ & $\mathrm{CR}$ & $\begin{array}{l}682 \\
934\end{array}$ & $\begin{array}{l}2,380 \\
2,090\end{array}$ & $\begin{array}{l}4,450 \\
3,090\end{array}$ & $\begin{array}{l}8,470 \\
4,650\end{array}$ & $\begin{array}{r}12,700 \\
6,010\end{array}$ & $\begin{array}{r}18,100 \\
7,560\end{array}$ & $\begin{array}{r}24,900 \\
9,340\end{array}$ & $\begin{array}{l}36,400 \\
12,040\end{array}$ & $\begin{array}{l}\mathrm{LP} 3 \mathrm{~W} \quad 43 \\
-\mathrm{N} \& \mathrm{~W}-\end{array}$ & $\begin{array}{l}1905, \\
1951-93\end{array}$ & 1967 & 13,000 \\
\hline $4008 \mathrm{a}$ & 06400875 & $\begin{array}{l}\text { Horsehead } \mathrm{Cr} \text { at Oelrichs, S. Dak.* } \\
(--0.271-\mathrm{New} \text { station for N\&W network analysis }) \\
\text { *Out-of-state station inadvertently used as new station }\end{array}$ & $\mathrm{CR}$ & 64 & $\begin{array}{l}1,100 \\
\text { Basin } \\
\text { App }\end{array}$ & $\begin{array}{l}4,430 \\
\text { aracteris } \\
\text { rs to req }\end{array}$ & $\begin{array}{l}18,400 \\
\text { stic(s) out } \\
\text { juire comp }\end{array}$ & $\begin{array}{l}44,700 \\
\text { de of ran } \\
\text { site frequ }\end{array}$ & $\begin{array}{l}96,800 \\
\text { ge for equa } \\
\text { lency analy }\end{array}$ & $\begin{array}{l}193,000 \\
\text { ations } \\
\text { lysis }\end{array}$ & 433,000 & $\begin{array}{l}\mathrm{LP} 3 \mathrm{~W} 11 \\
-\mathrm{N} \& \mathrm{~W}-\end{array}$ & 1983-93 & 1991 & 8,270 \\
\hline 4432 & 06443200 & $\begin{array}{l}\text { White R trib near Glen, Nebr. } \\
(-0.395-\text { Skew map }-0.282-\mathrm{N} \& \mathrm{~W})\end{array}$ & PS & $\begin{array}{l}36 \\
86\end{array}$ & $\begin{array}{l}174 \\
386\end{array}$ & $\begin{array}{l}378 \\
754\end{array}$ & $\begin{array}{r}834 \\
1,410\end{array}$ & $\begin{array}{l}1,370 \\
2,050\end{array}$ & $\begin{array}{l}2,100 \\
4,790\end{array}$ & $\begin{array}{l}3,080 \\
6,860\end{array}$ & $\begin{array}{r}4,840 \\
10,360\end{array}$ & $\begin{array}{l}\mathrm{LP} 3 \mathrm{~W} 18 \\
-\mathrm{N} \& \mathrm{~W}-\end{array}$ & 1953-70 & 1965 & 740 \\
\hline 4433 & 06443300 & $\begin{array}{l}\text { Deep Cr near Glen, Nebr. } \\
(-0.257-\text { Skew map, HP, N\&W }-0.254-\mathrm{N} \& W)\end{array}$ & PS & $\begin{array}{l}24 \\
68\end{array}$ & $\begin{array}{l}146 \\
270\end{array}$ & $\begin{array}{l}358 \\
500\end{array}$ & $\begin{array}{l}895 \\
892\end{array}$ & $\begin{array}{l}1,590 \\
1,270\end{array}$ & $\begin{array}{l}2,610 \\
3,590\end{array}$ & $\begin{array}{l}4,080 \\
4,900\end{array}$ & $\begin{array}{l}6,910 \\
6,980\end{array}$ & $\begin{array}{l}\text { LP3W } 26 \\
-\mathrm{N} \& \mathrm{~W}-\end{array}$ & 195 & 1953 & 3,050 \\
\hline 4437 & 06443700 & $\begin{array}{l}\text { Soldiers Cr near Crawford, Nebr. } \\
(+0.103-\text { Skew map, N\&W }-0.192-\mathrm{N} \& \mathrm{~W})\end{array}$ & PS & $\begin{array}{l}113 \\
232\end{array}$ & $\begin{array}{l}595 \\
810\end{array}$ & $\begin{array}{l}1,380 \\
1,430\end{array}$ & $\begin{array}{l}3,290 \\
2,450\end{array}$ & $\begin{array}{l}5,720 \\
3,410\end{array}$ & $\begin{array}{l}9,320 \\
6,770\end{array}$ & $\begin{array}{r}14,500 \\
9,280\end{array}$ & & $\begin{array}{l}\text { LP3W } 24 \\
-\mathrm{N} \& \mathrm{~W}-\end{array}$ & 195 & 1966 & 6,160 \\
\hline 4439 & 06443900 & $\begin{array}{l}\text { White R trib \#2 near Crawford, Nebr. } \\
(-1\end{array}$ & PS & & & $\begin{aligned} \text { ficient } \mathrm{d} \text {. } \\
\mathrm{N}\end{aligned}$ & & & & & & & 1953-70 & 1960 & 698 \\
\hline 4440 & 06444000 & $\begin{array}{l}\text { White } \mathrm{R} \text { at Crawford, Nebr. } \\
(-0.211-\mathrm{N} \& \mathrm{~W})\end{array}$ & $\mathrm{CR}$ & $\begin{array}{l}322 \\
437\end{array}$ & $\begin{array}{r}806 \\
1,190\end{array}$ & $\begin{array}{l}1,290 \\
1,910\end{array}$ & $\begin{array}{l}2,120 \\
3,070\end{array}$ & $\begin{array}{l}2,900 \\
4,120\end{array}$ & $\begin{array}{l}3,850 \\
8,560\end{array}$ & $\begin{array}{r}4,970 \\
11,200\end{array}$ & $\begin{array}{r}6,760 \\
15,300\end{array}$ & $\begin{array}{l}\text { LP3W } 75 \\
-\mathrm{N} \& W-\end{array}$ & $\begin{array}{l}1931-44, \\
1948-93\end{array}$ & 1991 & 13,300 \\
\hline 4450 & 06445000 & $\begin{array}{l}\text { White R below Cottonwood Cr near Whitney, Nebr. } \\
(-\quad-0.151 \text {-New station for N\&W network analysis) }\end{array}$ & CR & $\begin{array}{l}872 \\
819\end{array}$ & $\begin{array}{l}1,680 \\
1,980\end{array}$ & $\begin{array}{l}2,340 \\
3,000\end{array}$ & $\begin{array}{l}3,330 \\
4,490\end{array}$ & $\begin{array}{l}4,160 \\
5,860\end{array}$ & $\begin{array}{l}5,080 \\
9,370\end{array}$ & $\begin{array}{r}6,090 \\
12,000\end{array}$ & $\begin{array}{r}7,560 \\
15,800\end{array}$ & $\begin{array}{l}\mathrm{LP} 3 \mathrm{~W} \\
-\mathrm{N} \& \mathrm{~W}-\end{array}$ & 1949-61 & 1957 & 4,480 \\
\hline 4455 & 06445500 & $\begin{array}{l}\text { White R near Chadron, Nebr. } \\
(-0.091-\text { Skew map }-0.148-\mathrm{N} \& \mathrm{~W})\end{array}$ & CR & $\begin{array}{r}1,190 \\
859\end{array}$ & $\begin{array}{l}2,260 \\
2,040\end{array}$ & $\begin{array}{l}3,130 \\
3,050\end{array}$ & $\begin{array}{l}4,400 \\
4,590\end{array}$ & $\begin{array}{l}5,460 \\
5,920\end{array}$ & $\begin{array}{l}6,610 \\
9,510\end{array}$ & $\begin{array}{r}7,860 \\
12,060\end{array}$ & $\begin{array}{r}9,670 \\
15,900\end{array}$ & $\begin{array}{l}\mathrm{LP} 3 \mathrm{~W} \\
-\mathrm{N} \& \mathrm{~W}-\end{array}$ & $\begin{array}{l}1931-43 \\
1947 \\
1949-52\end{array}$ & 1947 & 5,500 \\
\hline $4455 \mathrm{a}$ & 06445530 & $\begin{array}{l}\text { Chadron Cr trib at Chadron State Park near Chadron, Nebr. } \\
(-\quad-0.241-\text { New station for N\&W network analysis) }\end{array}$ & $\mathrm{CR}$ & $<1$ & $\begin{array}{c}27 \\
231 \\
\text { Appears t }\end{array}$ & $\begin{array}{l}254 \\
463 \\
\text { equire c }\end{array}$ & $\begin{array}{c}2,480 \\
878 \\
\text { omposite }\end{array}$ & $\begin{array}{l}10,100 \\
1,300 \\
\text { requency }\end{array}$ & $\begin{array}{r}34,400 \\
2,260 \\
\text { analysis- }\end{array}$ & $\begin{array}{c}161,000 \\
3,170 \\
- \text { see fig. } 5\end{array}$ & $\begin{array}{r}360,000 \\
4,670\end{array}$ & $\begin{array}{l}\mathrm{LP} 3 \mathrm{~W} \\
-\mathrm{N} \& \mathrm{~W}-\end{array}$ & $1953-78$ & 1963 & 188 \\
\hline $4455 b$ & 06445560 & $\begin{array}{l}\text { Chadron Cr at Chadron State Park near Chadron, Nebr. } \\
(-.0372-\text { Skew map, N\&W }-0.333-\mathrm{N} \& \mathrm{~W})\end{array}$ & PS & $\begin{array}{r}55 \\
124\end{array}$ & $\begin{array}{l}395 \\
488\end{array}$ & $\begin{array}{r}1,020 \\
891\end{array}$ & $\begin{array}{l}2,650 \\
1,560\end{array}$ & $\begin{array}{l}4,760 \\
2,190\end{array}$ & $\begin{array}{l}7,910 \\
3,450\end{array}$ & $\begin{array}{r}12,400 \\
4,680\end{array}$ & $\begin{array}{r}20,800 \\
6,670\end{array}$ & $\begin{array}{l}\mathrm{LP} 3 \mathrm{~W} \\
-\mathrm{N} \& \mathrm{~W}-\end{array}$ & $1953-78$ & 1962 & 2,740 \\
\hline $4455 \mathrm{c}$ & 06445590 & $\begin{array}{l}\text { Big Bordeaux } \mathrm{Cr} \text { near Chadron, Nebr. } \\
(-0.318-\text { New station for N\&W network analysis) }\end{array}$ & $\mathrm{CR}$ & $\begin{array}{l}20 \\
90\end{array}$ & $\begin{array}{l}154 \\
378\end{array}$ & $\begin{array}{l}418 \\
711\end{array}$ & $\begin{array}{l}1,160 \\
1,270\end{array}$ & $\begin{array}{l}2,200 \\
1,830\end{array}$ & $\begin{array}{l}3,850 \\
3,620\end{array}$ & $\begin{array}{l}6,340 \\
5,020\end{array}$ & $\begin{array}{r}11,400 \\
7,300\end{array}$ & $\begin{array}{l}\mathrm{LP} 3 \mathrm{~W} 11 \\
-\mathrm{N} \& \mathrm{~W}-\end{array}$ & 1969-79 & 1977 & 5,670 \\
\hline
\end{tabular}


Table B2. Peak-flow frequency data for streamflow-gaging stations in Nebraska and for selected out-of-state stations,

and drainage areas for regulated streams--Continued

\begin{tabular}{|c|c|c|c|c|c|c|c|c|c|c|c|c|c|c|c|}
\hline$\underset{\text { num- }}{\text { Map }}$ & \multirow{2}{*}{$\begin{array}{c}\begin{array}{c}\text { Station } \\
\text { number }\end{array} \\
06446000\end{array}$} & \multirow{2}{*}{$\begin{array}{c}\begin{array}{c}\text { Station name } \\
\text { (station skew —skew relations }\end{array} \\
\text { skew-peak-flow regional equations or remarks) }\end{array}$} & \multirow{2}{*}{$\begin{array}{c}\begin{array}{c}\text { Gage } \\
\text { type }\end{array} \\
\text { PS, CR }\end{array}$} & \multicolumn{8}{|c|}{$\begin{array}{l}\text { Peak discharge }\left(\mathrm{ft}^{3} / \mathrm{s}\right) \text { for given recurrence interval (years) } \\
\text { and/or remarks }\end{array}$} & \multirow{2}{*}{$\begin{array}{c}\begin{array}{c}\text { Type and length } \\
\text { (years) of analysis } \\
\text { - regional } \\
\text { equation- }\end{array} \\
\text { LP3W } 50 \\
\text { - N\&W- }\end{array}$} & \multirow{2}{*}{$\begin{array}{c}\begin{array}{c}\text { Period of } \\
\text { peak-flow } \\
\text { record }\end{array} \\
1944-93\end{array}$} & \multicolumn{2}{|c|}{$\begin{array}{c}\text { WY and dis- } \\
\text { charge }\left(\mathrm{ft}^{3} / \mathrm{s}\right) \\
\text { of maximum } \\
\text { peak }\end{array}$} \\
\hline 蒠 & & & & $\begin{array}{r}866 \\
1,850\end{array}$ & $\begin{array}{l}1,690 \\
3,820\end{array}$ & $\begin{array}{l}2,360 \\
5,380\end{array}$ & $\begin{array}{l}3,330 \\
7,670\end{array}$ & $\begin{array}{l}4,150 \\
9,560\end{array}$ & $\begin{array}{r}5,030 \\
11,700\end{array}$ & $\begin{array}{r}5,980 \\
14,600\end{array}$ & $\begin{array}{r}7,340 \\
18,800\end{array}$ & & & 1947 & 5,200 \\
\hline 疋 & 06446400 & $\begin{array}{l}\text { Cain Cr trib at Imlay, S. Dak. } \\
(+0.090-\text { Skew map, N\&W }-0.237-\mathrm{N} \& W)\end{array}$ & PS & $\begin{array}{r}686 \\
85\end{array}$ & $\begin{array}{r}1,310 \\
329\end{array}$ & $\begin{array}{r}1,810 \\
617\end{array}$ & $\begin{array}{l}2,540 \\
1,140\end{array}$ & $\begin{array}{l}3,130 \\
1,660\end{array}$ & $\begin{array}{l}3,770 \\
1,590\end{array}$ & $\begin{array}{l}4,460 \\
2,040\end{array}$ & $\begin{array}{l}5,440 \\
2,760\end{array}$ & $\begin{array}{l}\text { LP3W } 25 \\
-\mathrm{N} \& \mathrm{~W}-\end{array}$ & $1956-80$ & 1962 & 3,300 \\
\hline ฉે๋ & 06446550 & $\begin{array}{l}\text { White R trib near Interior, S. Dak. } \\
(-0.379-\text { Skew map }-)\end{array}$ & PS & \multicolumn{8}{|c|}{$\begin{array}{l}\text { Out-of-state station used only for skew relation(s) } \\
\text { No basin characteristics }\end{array}$} & & $1956-80$ & 1980 & 575 \\
\hline$\frac{\frac{D}{0}}{\frac{0}{\#}}$ & 06447500 & $\begin{array}{l}\text { Little White R near Martin, S. Dak. } \\
(+0.235-\mathrm{HP}, \mathrm{N} \& \mathrm{~W}+0.018-\mathrm{HPS}, \mathrm{HPC}, \mathrm{N} \& \mathrm{~W})\end{array}$ & CR & $\begin{array}{l}188 \\
248 \\
182 \\
200\end{array}$ & $\begin{array}{l}409 \\
566 \\
433 \\
543\end{array}$ & $\begin{array}{r}618 \\
1,020 \\
841 \\
926\end{array}$ & $\begin{array}{r}964 \\
1,220 \\
1,180 \\
1,640\end{array}$ & $\begin{array}{l}1,290 \\
1,780 \\
1,560 \\
2,380\end{array}$ & $\begin{array}{l}1,670 \\
2,190 \\
2,040 \\
3,410\end{array}$ & $\begin{array}{l}2,130 \\
2,680 \\
2,610 \\
4,220\end{array}$ & $\begin{array}{l}2,860 \\
3,450 \\
3,570 \\
5,490\end{array}$ & $\begin{array}{l}\text { LP3W } 35 \\
\text {-HPS- } \\
\text {-HPC- } \\
\text {-N\&W- }\end{array}$ & $\begin{array}{c}1932 \\
1938-40 \\
1962-93\end{array}$ & 1965 & 1,190 \\
\hline 亏ัँ & 06448000 & $\begin{array}{l}\text { Lake } \mathrm{Cr} \text { above refuge near Tuthill, S. Dak. } \\
(-)\end{array}$ & $\mathrm{CR}$ & 79 & 111 & $\begin{array}{r}130 \\
\text { Basin }\end{array}$ & $\begin{aligned} & 152 \\
\text { haracteris } & \end{aligned}$ & $\begin{array}{l}167 \\
\text { stics incon }\end{array}$ & aplete 181 & 194 & 211 & LP3S 21 & $\begin{array}{l}1938-40 \\
1962-79\end{array}$ & 1966 & 154 \\
\hline$\stackrel{Ð}{\stackrel{\Xi}{\rightleftarrows}}$ & 06449100 & $\begin{array}{l}\text { Little White R near Vetal, S. Dak. } \\
(-\quad+0.268-\text { HPS, N\&W })\end{array}$ & CR & $\begin{array}{l}313 \\
436 \\
290\end{array}$ & $\begin{array}{r}662 \\
1,000 \\
742\end{array}$ & $\begin{array}{l}1,010 \\
1,590 \\
1,230\end{array}$ & $\begin{array}{l}1,600 \\
2,360 \\
2,130\end{array}$ & $\begin{array}{l}2,200 \\
3,710 \\
3,060\end{array}$ & $\begin{array}{l}2,930 \\
4,640 \\
4,110\end{array}$ & $\begin{array}{l}3,850 \\
5,740 \\
5,060\end{array}$ & $\begin{array}{l}5,400 \\
7,500 \\
6,530\end{array}$ & $\begin{array}{l}\text { LP3W } 34 \\
\text {-HPS- } \\
\text {-N\&W- }\end{array}$ & 1960-93 & 1991 & 3,540 \\
\hline 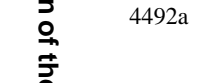 & 06449250 & 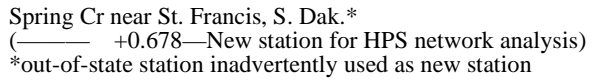 & PS & $\begin{array}{r}38 \\
258\end{array}$ & $\begin{array}{r}53 \\
500\end{array}$ & $\begin{array}{r}62 \\
644\end{array}$ & $\begin{array}{r}72 \\
965\end{array}$ & $\begin{array}{r}78 \\
1,390\end{array}$ & $\begin{array}{r}84 \\
1,720\end{array}$ & $\begin{array}{r}89 \\
2,110\end{array}$ & $\begin{array}{r}95 \\
2,790\end{array}$ & $\begin{array}{l}\text { LP3S } 15 \\
\text {-HPS- }\end{array}$ & $1960-74$ & 1962 & 65 \\
\hline $\begin{array}{l}\mathbb{D} \\
\mathbb{D} \\
\frac{\mathbb{N}}{\hat{1}} \\
\text { ᄁᄁ }\end{array}$ & 06449500 & $\begin{array}{l}\text { Little White R near Rosebud, S. Dak. } \\
(+0.642-\mathrm{HP}, \mathrm{N} \& \mathrm{~W}+0.404-\mathrm{HPS}, \mathrm{HPC}, \mathrm{N} \& \mathrm{~W})\end{array}$ & CR & $\begin{array}{r}692 \\
1,480 \\
1,030 \\
466\end{array}$ & $\begin{array}{l}1,460 \\
2,820 \\
2,190 \\
1,120\end{array}$ & $\begin{array}{l}2,230 \\
3,790 \\
3,070 \\
1,790\end{array}$ & $\begin{array}{l}3,620 \\
5,290 \\
4,170 \\
3,000\end{array}$ & $\begin{array}{l}5,020 \\
6,780 \\
5,510 \\
4,200\end{array}$ & $\begin{array}{l}6,830 \\
8,500 \\
7,140 \\
7,540\end{array}$ & $\begin{array}{r}9,120 \\
10,500 \\
9,130 \\
9,200\end{array}$ & $\begin{array}{l}13,100 \\
13,800 \\
12,400 \\
12,000\end{array}$ & $\begin{array}{c}\text { LP3W } 50 \\
\text { - HPS- } \\
\text { - HPC- } \\
\text {-N\&W- }\end{array}$ & 1944-93 & 1967 & 4,640 \\
\hline$\sum$ & 06449700 & $\begin{array}{l}\text { Little Oak Cr near Mission, S. Dak. } \\
(-0.283 \text {-Skew map, N\&W }\end{array}$ & PS & \multicolumn{9}{|c|}{$\begin{array}{l}\text { Out-of-state station used only for skew relation(s) } \\
\text { Some basin characteristics unreliable }\end{array}$} & $1956-80$ & 1977 & 970 \\
\hline قํㅡㄹ & 06449750 & $\begin{array}{l}\text { W Br Horse Cr near Mission, S. Dak. } \\
(-0.381-\mathrm{N} \& \mathrm{~W})\end{array}$ & PS & $\begin{array}{r}24 \\
120\end{array}$ & $\begin{array}{l}127 \\
562\end{array}$ & $\begin{array}{r}280 \\
1,100\end{array}$ & $\begin{array}{r}616 \\
2,050\end{array}$ & $\begin{array}{r}998 \\
2,960\end{array}$ & $\begin{array}{l}1,510 \\
2,640\end{array}$ & $\begin{array}{l}2,170 \\
3,680\end{array}$ & $\begin{array}{l}3,310 \\
5,430\end{array}$ & $\begin{array}{l}\mathrm{LP} 3 \mathrm{~W} \\
-\mathrm{N} \& \mathrm{~W}-\end{array}$ & $1956-70$ & 1968 & 548 \\
\hline 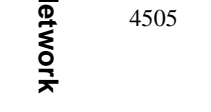 & 06450500 & $\begin{array}{l}\text { Little White R below White R, S. Dak. } \\
(+0.458-\mathrm{HP}, \mathrm{N} \& \mathrm{~W}+0.246-\mathrm{HPS}, \mathrm{HPC}, \mathrm{N} \& \mathrm{~W})\end{array}$ & $\mathrm{CR}$ & $\begin{array}{r}1,690 \\
2,760 \\
2,290 \\
809\end{array}$ & $\begin{array}{l}3,660 \\
5,030 \\
4,690 \\
1,820\end{array}$ & $\begin{array}{l}5,630 \\
6,100 \\
5,860 \\
2,810\end{array}$ & $\begin{array}{l}9,100 \\
9,010 \\
9,140 \\
4,470\end{array}$ & $\begin{array}{r}12,500 \\
11,200 \\
12,000 \\
6,050\end{array}$ & $\begin{array}{r}16,800 \\
14,000 \\
15,600 \\
9,690\end{array}$ & $\begin{array}{l}22,200 \\
17,400 \\
20,000 \\
12,200\end{array}$ & $\begin{array}{l}31,300 \\
22,800 \\
27,300 \\
16,000\end{array}$ & $\begin{array}{c}\text { LP3W } 48 \\
\text {-HPS- } \\
\text {-HPC- } \\
\text {-N\&W- }\end{array}$ & $\begin{array}{l}\text { 1930-32, } \\
1939-40 \\
1951-93\end{array}$ & 1967 & 13,700 \\
\hline 4534 & 06453400 & $\begin{array}{l}\text { Ponca Cr near Naper, Nebr. } \\
(-\stackrel{\longrightarrow}{\longrightarrow}\end{array}$ & CR & 855 & $\begin{array}{l}1,600 \\
\text { No b }\end{array}$ & $\begin{array}{l}2,220 \\
\text { sin char }\end{array}$ & $\begin{array}{l}3,130 \\
\text { teristics }\end{array}$ & $\begin{array}{c}3,900 \\
\text { Gage itse }\end{array}$ & $\begin{array}{l}4,760 \\
\text { If is in S. I }\end{array}$ & $\begin{array}{l}5,700 \\
\text { Dak. }\end{array}$ & 7,080 & LP3W 13 & 1961-74 & 1962 & 2,840 \\
\hline 4535 & 06453500 & $\begin{array}{l}\text { Ponca Cr at Anoka, Nebr. } \\
(-0.228-\text { Skew map, HP, N\&W, NE } \quad-0.041-\mathrm{N} \& \mathrm{~W})\end{array}$ & CR & $\begin{array}{l}1,370 \\
1,030\end{array}$ & $\begin{array}{l}3,090 \\
2,830\end{array}$ & $\begin{array}{l}4,700 \\
4,630\end{array}$ & $\begin{array}{l}7,310 \\
7,620\end{array}$ & $\begin{array}{r}9,690 \\
10,400\end{array}$ & $\begin{array}{l}12,500 \\
11,200\end{array}$ & $\begin{array}{l}15,700 \\
14,000\end{array}$ & $\begin{array}{l}20,600 \\
18,600\end{array}$ & $\begin{array}{l}\text { LP3W } 45 \\
-\mathrm{N} \& \mathrm{~W}-\end{array}$ & 1949-93 & 1960 & 9,810 \\
\hline 4536 & 06453600 & $\begin{array}{l}\text { Ponca } \mathrm{Cr} \text { at Verdel, Nebr. } \\
(+0.033-\text { Skew map, HP, N\&W, NE } \quad-0.034-\mathrm{N} \& \mathrm{~W})\end{array}$ & CR & $\begin{array}{l}1,610 \\
1,240\end{array}$ & $\begin{array}{l}3,860 \\
3,180\end{array}$ & $\begin{array}{l}6,060 \\
5,070\end{array}$ & $\begin{array}{l}9,760 \\
8,170\end{array}$ & $\begin{array}{l}13,200 \\
11,000\end{array}$ & $\begin{array}{l}17,400 \\
14,000\end{array}$ & $\begin{array}{l}22,300 \\
18,600\end{array}$ & $\begin{array}{l}30,100 \\
26,000\end{array}$ & $\begin{array}{l}\text { LP3W } 36 \\
-\mathrm{N} \& \mathrm{~W}-\end{array}$ & 1958-93 & 1960 & 15,700 \\
\hline 4540 & 06454000 & $\begin{array}{l}\text { Niobrara } \mathrm{R} \text { at Wyoming-Nebraska state line } \\
\left(455 \mathrm{mi}^{2} \text {, approximately }\right)\end{array}$ & CR & 46 & 174 & 378 & 925 & 1,710 & 3,050 & 5,290 & 10,600 & REG 38 & 1956-93 & 1977 & 2,120 \\
\hline 4541 & 06454100 & Niobrara $\mathrm{R}$ at Agate, Nebr. $\left(840 \mathrm{mi}^{2}\right)$ & $\mathrm{CR}$ & 52 & 84 & 111 & 152 & 188 & 229 & 277 & 350 & REG 35 & 1958-92 & 1959 & 181 \\
\hline 4545 & 06454500 & Niobrara $R$ above Box Butte Reservoir, Nebr. $\quad\left(1,400 \mathrm{mi}^{2}\right)$ & CR & 149 & 352 & 639 & 1,360 & 2,360 & 4,070 & 6,960 & 14,000 & REG 47 & $1947-93$ & 1951 & 4950 \\
\hline
\end{tabular}


Table B2. Peak-flow frequency data for streamflow-gaging stations in Nebraska and for selected out-of-state stations,

and drainage areas for regulated streams--Continued

\begin{tabular}{|c|c|c|c|c|c|c|c|c|c|c|c|c|c|c|c|}
\hline \multirow{3}{*}{$\begin{array}{c}\begin{array}{c}\text { Map } \\
\text { num- } \\
\text { ber }\end{array} \\
4555\end{array}$} & \multirow{3}{*}{$\begin{array}{c}\begin{array}{c}\text { Station } \\
\text { number }\end{array} \\
06455500\end{array}$} & \multirow{3}{*}{$\begin{array}{c}\text { Station name } \\
\begin{array}{c}\text { (station skew-skew relations generalized } \\
\text { skew-peak-flow regional equations or remarks) }\end{array} \\
\text { Niobrara R below Box Butte Reservoir, Nebr. } \quad\left(1,460 \mathrm{mi}^{2}\right)\end{array}$} & \multirow{3}{*}{$\begin{array}{c}\text { Gage } \\
\text { type }\end{array}$} & \multicolumn{8}{|c|}{$\begin{array}{l}\left.\text { Peak discharge ( } \mathrm{ft}^{3} / \mathrm{s}\right) \text { for given recurrence interval (years) } \\
\text { and/or remarks }\end{array}$} & \multirow{3}{*}{$\begin{array}{c}\begin{array}{c}\text { Type and length } \\
\text { (years) of analysis } \\
\text { - regional } \\
\text { equation- }\end{array} \\
\text { REG } 47\end{array}$} & \multirow{3}{*}{$\begin{array}{c}\begin{array}{c}\text { Period of } \\
\text { peak-flow } \\
\text { record }\end{array} \\
1947-93\end{array}$} & \multirow{2}{*}{\multicolumn{2}{|c|}{$\begin{array}{l}\text { WY and dis- } \\
\left.\text { charge ( } \mathrm{ft}^{3} / \mathrm{s}\right) \\
\text { of maximum } \\
\text { peak }\end{array}$}} \\
\hline & & & & 2 & 5 & 10 & 25 & 50 & 100 & 200 & 500 & & & & \\
\hline & & & & 186 & 223 & 263 & 332 & 400 & 483 & 585 & 758 & & & 1968 & 616 \\
\hline 4559 & 06455900 & Niobrara R near Dunlap, Nebr. $\quad\left(1,580 \mathrm{mi}^{2}\right)$ & $\mathrm{CR}$ & 193 & 385 & 748 & 1,980 & 4,320 & 9,670 & 22,100 & 67,100 & REG 10 & $\begin{array}{l}1931-42 \\
1962-71\end{array}$ & 1962 & 3,230 \\
\hline 4562 & 06456200 & $\begin{array}{l}\text { Pebble Cr near Esther, Nebr. } \\
(--0.157-\mathrm{N} \& \mathrm{~W})\end{array}$ & PS & $\begin{array}{r}8 \\
29\end{array}$ & $\begin{array}{r}57 \\
131\end{array}$ & $\begin{array}{l}154 \\
266\end{array}$ & $\begin{array}{l}438 \\
535\end{array}$ & $\begin{array}{l}854 \\
822\end{array}$ & $\begin{array}{l}1,550 \\
1,060\end{array}$ & $\begin{array}{l}2,640 \\
1,400\end{array}$ & $\begin{array}{l}5,040 \\
1,940\end{array}$ & $\begin{array}{l}\text { LP3W } 26 \\
-\mathrm{N} \& \mathrm{~W}-\end{array}$ & 1953-78 & 1953 & 2,000 \\
\hline 4563 & 06456300 & $\begin{array}{l}\text { Pebble Cr near Dunlap, Nebr. } \\
(--0.132-\mathrm{N} \& \mathrm{~W})\end{array}$ & PS & $\begin{array}{r}11 \\
140\end{array}$ & $\begin{array}{l}507 \\
523 \\
\text { App }\end{array}$ & $\begin{array}{l}1,640 \\
955 \\
\text { ears to re }\end{array}$ & $\begin{array}{l}3,580 \\
1,710 \\
\text { |uire com }\end{array}$ & $\begin{aligned} & 4,900 \\
& 2,440 \\
& \text { posite frequ }\end{aligned}$ & $\begin{array}{c}5,910 \\
3,010 \\
\text { iency analy }\end{array}$ & $\begin{array}{r}6,630 \\
4,010 \\
\text { ysis }\end{array}$ & $\begin{array}{l}7,230 \\
5,610\end{array}$ & $\begin{array}{l}\text { LP3S } 18 \\
-\mathrm{N} \& W-\end{array}$ & 1953-70 & 1965 & 3,300 \\
\hline 4564 & 06456400 & $\begin{array}{l}\text { Cottonwood Cr near Dunlap, Nebr. } \\
(-0.627-\text { Skew map, N\&W } \\
\text { N\&W network analysis })\end{array}$ & PS & $\begin{array}{r}25 \\
160\end{array}$ & $\begin{array}{l}367 \\
827 \\
\text { App }\end{array}$ & $\begin{array}{l}1,430 \\
1,430 \\
\text { ears to rec }\end{array}$ & $\begin{array}{l}5,900 \\
2,410 \\
\text { quire com }\end{array}$ & $\begin{array}{c}14,500 \\
3,390 \\
\text { posite frequ }\end{array}$ & $\begin{array}{c}32,100 \\
4,130 \\
\text { iency analy }\end{array}$ & $\begin{array}{r}66,000 \\
5,390 \\
\text { ysis }\end{array}$ & $\begin{array}{r}156,000 \\
7,270\end{array}$ & $\frac{\mathrm{LP} 3 \mathrm{~W}}{-\mathrm{N} \& \mathrm{~W}-}$ & $1951-78$ & 1951 & 28,100 \\
\hline 4565 & 06456500 & $\begin{array}{l}\text { Niobrara R near Hay Springs, Nebr. } \\
\text { (drainage area not published) }\end{array}$ & CR & 761 & 2,210 & 3,810 & 6,740 & 9,670 & 13,300 & 17,800 & 25,300 & REG 15 & $1950-64$ & 1951 & 7,330 \\
\hline 4572 & 06457200 & $\begin{array}{l}\text { Berea Cr near Alliance, Nebr. } \\
\left(\begin{array}{c}\longrightarrow 0.250-\text { New station for } \mathrm{N} \& \mathrm{~W} \text { network analysis })\end{array}\right.\end{array}$ & PS & $\begin{array}{l}34 \\
28\end{array}$ & $\begin{array}{l}73 \\
72 \\
\text { Basin }\end{array}$ & $\begin{array}{r}102 \\
118 \\
\text { characteri } \\
\text { Poss }\end{array}$ & $\begin{array}{r}136 \\
204 \\
\text { ic(s) out } \\
\text { ly affect }\end{array}$ & $\begin{array}{l}160 \\
292 \\
\text { ttside of rang } \\
\text { ted by irriga }\end{array}$ & $\begin{array}{l}182 \\
\quad 404 \\
\text { ge for equa } \\
\text { ation }\end{array}$ & $\begin{array}{l}202 \\
547 \\
\text { ations }\end{array}$ & $\begin{array}{l}226 \\
792\end{array}$ & $\begin{array}{ll}\text { LP3S } & 26 \\
\text { LP3W } & 26 \\
-\mathrm{N} \& W-\end{array}$ & $1953-78$ & 1977 & 130 \\
\hline 4575 & 06457500 & Niobrara R near Gordon, Nebr. $\quad\left(4,290 \mathrm{mi}^{2}\right)$ & $\mathrm{CR}$ & 771 & 1,970 & 3,420 & 6,420 & 9,910 & 14,900 & 21,900 & 35,700 & REG 48 & $\begin{array}{l}1929-32 \\
1946-93\end{array}$ & 1962 & 9,130 \\
\hline 4577 & 06457700 & $\begin{array}{l}\text { Antelope } \mathrm{Cr} \text { at Gordon, Nebr. } \\
(-\end{array}$ & PS & 95 & $\begin{array}{l}238 \\
\text { Reg }\end{array}$ & $\begin{array}{l}377 \\
\text { ulated aft }\end{array}$ & $\begin{array}{r}611 \\
\text { er } 1965\end{array}$ & $\begin{array}{c}827 \\
\text { No basin cl }\end{array}$ & $\begin{array}{l}1,080 \\
\text { haracterist }\end{array}$ & $\operatorname{tics}^{1,380}$ & 1,840 & LP3W 13 & $1953-65$ & 1958 & 444 \\
\hline 4578 & 06457800 & 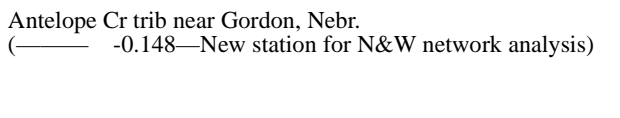 & PS & $\begin{array}{r}2 \\
<1 \\
148\end{array}$ & $\begin{array}{c}230 \\
253 \\
565 \\
\text { Appears to }\end{array}$ & $\begin{array}{l}1,330 \\
5,840 \\
1,060 \\
\text { require }\end{array}$ & $\begin{array}{r}5,260 \\
146,000 \\
1,920 \\
\text { omposite }\end{array}$ & $\frac{10,100}{2,810}$ & $\begin{array}{c}16,000 \\
\quad>1,00 \\
4,020 \\
\text { analysis- }\end{array}$ & $\begin{array}{l}22,100 \\
0,000 \\
5,500 \\
\text { see fig. } 5\end{array}$ & $\frac{29,700}{7,910}$ & $\begin{array}{l}\text { LP3S } 26 \\
\text { LP3W } 26 \\
-\mathrm{N} \& W-\end{array}$ & 1953-78 & 1955 & 1,900 \\
\hline 4590 & 06459000 & Niobrara R at Cody, Nebr. $\quad\left(5,570 \mathrm{mi}^{2}\right)$ & $\mathrm{CR}$ & 1,890 & 3,020 & 3,870 & 5,050 & 6,020 & 7,060 & 8,170 & 9,760 & REG 10 & $1948-57$ & 1951 & 4,170 \\
\hline 4591a & 06459175 & $\begin{array}{l}\text { Snake R at Doughboy, Nebr. } \\
(-\quad+1.060-\text { New station for HPS network analysis })\end{array}$ & CR & $\begin{array}{l}278 \\
247\end{array}$ & $\begin{array}{l}327 \\
348\end{array}$ & $\begin{array}{l}362 \\
423\end{array}$ & $\begin{array}{l}409 \\
544\end{array}$ & $\begin{array}{l}446 \\
594\end{array}$ & $\begin{array}{l}485 \\
753\end{array}$ & $\begin{array}{l}526 \\
943\end{array}$ & $\begin{array}{r}583 \\
1,290\end{array}$ & $\begin{array}{l}\text { LP3W } 12 \\
-\mathrm{HPS}-\end{array}$ & $1982-93$ & 1991 & 367 \\
\hline 4592 & 06459200 & $\begin{array}{l}\text { Snake } \mathrm{R} \text { above Merritt Reservoir, Nebr. } \\
(+0.714-\mathrm{N} \& \mathrm{~W}+1.071-\mathrm{HPS}, \mathrm{HPC})\end{array}$ & CR & $\begin{array}{l}436 \\
282 \\
299\end{array}$ & $\begin{array}{l}546 \\
394 \\
340\end{array}$ & $\begin{array}{l}629 \\
475 \\
427\end{array}$ & $\begin{array}{l}748 \\
556 \\
388\end{array}$ & $\begin{array}{l}846 \\
567 \\
474\end{array}$ & $\begin{array}{l}952 \\
712 \\
573\end{array}$ & $\begin{array}{r}1,070 \\
886 \\
688\end{array}$ & $\begin{array}{r}1,240 \\
1,170 \\
869\end{array}$ & $\begin{array}{l}\text { LP3W } 22 \\
\text {-HPS- } \\
\text {-HPC- }\end{array}$ & $1962-81$ & 1962 & 820 \\
\hline 4595 & 06459500 & $\begin{array}{l}\text { Snake } \mathrm{R} \text { near Burge, Nebr. } \\
\quad\left(600 \mathrm{mi}^{2} \text {, approximately, of which about } 44 \mathrm{mi}^{2} \text { contributes }\right.\end{array}$ & $\begin{array}{l}\mathrm{CR} \\
\text { directly }\end{array}$ & $\begin{array}{l}370 \\
\text { to surface }\end{array}$ & $\begin{array}{r}471 \\
\text { runoff) }\end{array}$ & 552 & 673 & 777 & 893 & 1,020 & 1,220 & REG 30 & 1947-93 & 1963 & 3,170 \\
\hline 4609 & 06460900 & $\begin{array}{l}\text { Minnechaduza Cr near Kilgore, Nebr. } \\
(-\quad+0.559-\text { New station for HPS network analysis })\end{array}$ & CR & $\begin{array}{r}64 \\
263\end{array}$ & $\begin{array}{l}102 \\
484\end{array}$ & $\begin{array}{l}128 \\
596\end{array}$ & $\begin{array}{l}160 \\
858\end{array}$ & $\begin{array}{r}183 \\
1,170\end{array}$ & $\begin{array}{r}206 \\
1,440\end{array}$ & $\begin{array}{r}228 \\
1,760\end{array}$ & $\begin{array}{r}256 \\
2,320\end{array}$ & $\begin{array}{l}\text { LP3S } 17 \\
\text {-HPS- }\end{array}$ & $1958-74$ & 1968 & 147 \\
\hline 4610 & 06461000 & $\begin{array}{l}\text { Minnechaduza Cr at Valentine, Nebr. } \\
\left(390 \mathrm{mi}^{2} \text {, approximately, of which about } 200 \mathrm{mi}^{2} \text { contributes }\right.\end{array}$ & $\begin{array}{l}\text { CR } \\
\text { s directly }\end{array}$ & $\begin{array}{l}193 \\
\text { to surface }\end{array}$ & $\begin{array}{l}364 \\
\text { e runoff) }\end{array}$ & 523 & 793 & 1,050 & 1,370 & 1,760 & 2,410 & REG 46 & 1948-93 & 1960 & 1,100 \\
\hline 4615 & 06461500 & Niobrara R near Sparks, Nebr. $\quad\left(8,090 \mathrm{mi}^{2}\right.$, approximately $)$ & $\mathrm{CR}$ & 2,470 & 3,720 & 4,730 & 6,240 & 7,550 & 9,020 & 10,700 & 13,200 & REG 30 & $1946-93$ & 1949 & 10,200 \\
\hline
\end{tabular}


Table B2. Peak-flow frequency data for streamflow-gaging stations in Nebraska and for selected out-of-state stations,

and drainage areas for regulated streams--Continued

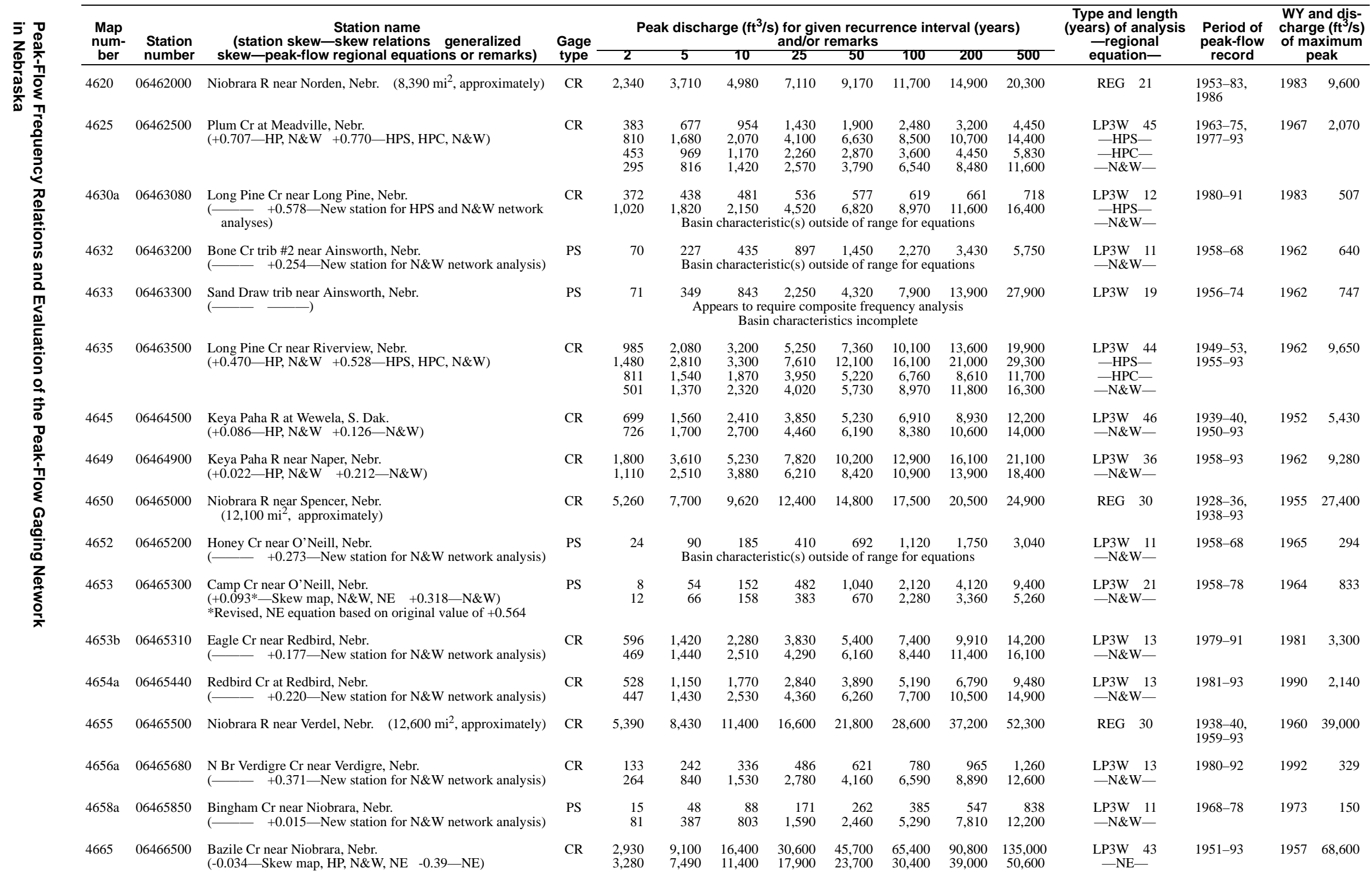


Table B2. Peak-flow frequency data for streamflow-gaging stations in Nebraska and for selected out-of-state stations,

and drainage areas for regulated streams--Continued

\begin{tabular}{|c|c|c|c|c|c|c|c|c|c|c|c|c|c|c|c|}
\hline \multirow{2}{*}{$\begin{array}{c}\begin{array}{c}\text { Map } \\
\text { num- } \\
\text { ber }\end{array} \\
4669 \mathrm{a}\end{array}$} & \multirow{2}{*}{$\begin{array}{c}\begin{array}{c}\text { Station } \\
\text { number }\end{array} \\
06466950\end{array}$} & \multirow{2}{*}{$\begin{array}{c}\begin{array}{c}\text { Station name } \\
\text { (station skew_skew relations } \\
\text { skew-peak-flow regional equations or remarks) }\end{array} \\
\text { Weigand Cr near Crofton, Nebr. } \\
(-\quad-0.006 \text {-New station for NE network analysis })\end{array}$} & \multirow{2}{*}{$\begin{array}{c}\begin{array}{c}\text { Gage } \\
\text { type }\end{array} \\
\text { PS }\end{array}$} & \multicolumn{8}{|c|}{$\begin{array}{c}\text { Peak discharge }\left(\mathrm{ft}^{3} / \mathbf{s}\right) \text { for given recurrence interval (years) } \\
\text { and/or remarks }\end{array}$} & \multirow{2}{*}{$\begin{array}{c}\begin{array}{c}\text { Type and length } \\
\text { (years) of analysis } \\
\text {-regional }\end{array} \\
\text { equation- } \\
\text { LP3W } 11 \\
\text { LP3S 11 } \\
\text { - NE- }\end{array}$} & \multirow{2}{*}{$\begin{array}{c}\begin{array}{c}\text { Period of } \\
\text { peak-flow } \\
\text { record }\end{array} \\
1968-78\end{array}$} & \multicolumn{2}{|c|}{$\begin{array}{c}\text { WY and dis- } \\
\text { charge }\left(\mathrm{ft}^{3} / \mathrm{s}\right) \\
\text { of maximum } \\
\text { peak }\end{array}$} \\
\hline & & & & $\begin{array}{r}74 \\
92 \\
180\end{array}$ & $\begin{array}{l}360 \\
367 \\
465 \\
\mathrm{Ap}\end{array}$ & $\begin{array}{r}813 \\
665 \\
762 \\
\text { ars to re }\end{array}$ & $\begin{array}{c}1,910 \\
1,140 \\
1,290 \\
\text { uire com }\end{array}$ & $\begin{array}{l}3,290 \\
1,550 \\
1,820 \\
\text { osite frea }\end{array}$ & $\begin{array}{r}5,340 \\
1,980 \\
2,460 \\
\text { ency ana }\end{array}$ & $\begin{array}{r}8,290 \\
2,410 \\
3,340\end{array}$ & $\begin{array}{r}14,100 \\
2,990 \\
4,520\end{array}$ & & & 1970 & 928 \\
\hline $4782 \mathrm{a}$ & 06478260 & $\begin{array}{l}\text { N Br Dry } \mathrm{Cr} \text { near Parkston, S. Dak. } \\
(+0.072-\mathrm{N} \& \mathrm{~W} \longrightarrow)\end{array}$ & PS & & & -of-state s & ation used & only for $\mathrm{s}$ & kew relati & on(s) & & & $1956-78$ & 1969 & 3,200 \\
\hline $4782 \mathrm{~b}$ & 06478280 & $\begin{array}{l}\text { S Br Dry Cr near Parkston, S. Dak. } \\
(+0.266-\text { Skew map, N\&W, NE }\end{array}$ & PS & & & -of-state s & ation used & only for $\mathrm{s}$ & kew relati & on(s) & & & $1956-80$ & 1960 & 920 \\
\hline 4783 & 06478300 & $\begin{array}{l}\text { Dry Cr near Parkston, S. Dak. } \\
(+0.107-\text { Skew map, N\&W, NE } \longrightarrow)\end{array}$ & PS & & & -of-state s & ation used & only for $\mathrm{s}$ & kew relati & on(s) & & & $\begin{array}{l}1956-80 \\
1989-93\end{array}$ & 1960 & 4,210 \\
\hline $4785 a$ & 06478518 & $\begin{array}{l}\text { Bow Cr near St James, Nebr. } \\
(--0.108-\mathrm{NE})\end{array}$ & $\mathrm{CR}$ & $\begin{array}{l}3,340 \\
2,430\end{array}$ & $\begin{array}{l}7,240 \\
5,490\end{array}$ & $\begin{array}{r}10,800 \\
8,330\end{array}$ & $\begin{array}{l}16,400 \\
12,900\end{array}$ & $\begin{array}{l}21,500 \\
17,000\end{array}$ & $\begin{array}{l}27,300 \\
21,700\end{array}$ & $\begin{array}{l}34,000 \\
26,700\end{array}$ & $\begin{array}{l}44,300 \\
34,800\end{array}$ & $\begin{array}{l}\mathrm{LP} 3 \mathrm{~W} \\
-\mathrm{NE}-\end{array}$ & $1979-93$ & 1984 & 21,400 \\
\hline $4785 b$ & 06478520 & $\begin{array}{l}\text { W Bow Cr near Fordyce, Nebr. } \\
(-0.002-\text { New station for NE network analysis })\end{array}$ & PS & $\begin{array}{l}379 \\
913\end{array}$ & $\begin{array}{l}1,360 \\
2,120\end{array}$ & $\begin{array}{l}2,630 \\
3,240\end{array}$ & $\begin{array}{l}5,300 \\
5,100\end{array}$ & $\begin{array}{l}8,310 \\
6,810\end{array}$ & $\begin{array}{r}12,400 \\
8,750\end{array}$ & $\begin{array}{l}17,900 \\
10,700\end{array}$ & $\begin{array}{l}27,900 \\
14,200\end{array}$ & $\stackrel{\mathrm{LP} 3 \mathrm{~W}}{-\mathrm{NE}-}$ & $\begin{array}{l}1964-65, \\
1967-78\end{array}$ & 1967 & 3,150 \\
\hline 4786a & 06478690 & $\begin{array}{l}\text { W Fk Vermillion R near Parker, S. Dak. } \\
(-0.392-\text { Skew map }\end{array}$ & $\mathrm{CR}$ & & & -of-state s & $\begin{array}{l}\text { ation used } \\
\text { Io basin cl }\end{array}$ & $\begin{array}{l}\text { only for s } \\
\text { aracteristi }\end{array}$ & $\begin{array}{l}\text { kew relati } \\
\text { cs }\end{array}$ & on(s) & & & $1962-93$ & 1993 & 6,300 \\
\hline 4788 & 06478800 & $\begin{array}{l}\text { Saddlerock Cr near Canton, S. Dak. } \\
(+0.184-\mathrm{N} \& \mathrm{~W} \longrightarrow)\end{array}$ & PS & & & -of-state s & ation used & only for $\mathrm{s}$ & kew relati & on(s) & & & $1956-78$ & 1965 & 945 \\
\hline $4788 \mathrm{~b}$ & 06478820 & $\begin{array}{l}\text { Saddlerock Cr trib near Beresford, S. Dak. } \\
(-0.070 \text { - Skew map, N\&W, NE }\end{array}$ & PS & & & -of-state s & ation used & only for $\mathrm{s}$ & kew relati & on(s) & & & $1956-80$ & 1978 & 120 \\
\hline $4788 c$ & 06478840 & $\begin{array}{l}\text { Saddlerock Cr near Beresford, S. Dak. } \\
(-0.169-\mathrm{N} \& \mathrm{~W} \longrightarrow)\end{array}$ & PS & & & -of-state s & ation used & only for s & kew relati & on(s) & & & $\begin{array}{l}1956-70 \\
1972-80\end{array}$ & 1965 & 1,480 \\
\hline 4790 & 06479000 & $\begin{array}{l}\text { Vermillion R near Wakonda, S. Dak. } \\
(+0.008 \text {-Skew map }\end{array}$ & CR, PS & & & -of-state s & $\begin{array}{l}\text { ation used } \\
\text { lo basin cl }\end{array}$ & $\begin{array}{l}\text { only for s } \\
\text { aracteristi }\end{array}$ & $\begin{array}{l}\text { kew relati } \\
\text { cs }\end{array}$ & on(s) & & & $1946-93$ & 1984 & 17,000 \\
\hline 4815 & 06481500 & $\begin{array}{l}\text { Skunk Cr at Sioux Falls, S. Dak. } \\
(-0.112-\text { Skew map }-)\end{array}$ & $\mathrm{CR}$ & & & -of-state s & $\begin{array}{l}\text { ation used } \\
\text { o basin cl }\end{array}$ & $\begin{array}{l}\text { only for s } \\
\text { aracteristi }\end{array}$ & kew relati & on $(\mathrm{s})$ & & & 1949-93 & 1957 & 29,400 \\
\hline $4826 a$ & 06482610 & $\begin{array}{l}\text { Split Rock Cr at Corson, S. Dak. } \\
(+0.337-\text { Skew map }-)\end{array}$ & CR, PS & & & -of-state $\mathrm{s}$ & $\begin{array}{l}\text { ation used } \\
\text { Io basin cl }\end{array}$ & $\begin{array}{l}\text { only for s } \\
\text { haracteristi }\end{array}$ & ew relati & $n(s)$ & & & $1966-93$ & 1993 & 18,900 \\
\hline 4835 & 06483500 & $\begin{array}{l}\text { Rock R near Rock Valley, Iowa } \\
(-0.348 \text {-Skew map }-)\end{array}$ & PS, CR & & & -of-state s & $\begin{array}{l}\text { ation used } \\
\text { Io basin cl }\end{array}$ & $\begin{array}{l}\text { only for s } \\
\text { aracteristi }\end{array}$ & w relati & $n(s)$ & & & $\begin{array}{l}1897 \\
1948-93\end{array}$ & 1969 & 40,400 \\
\hline 4840 & 06484000 & $\begin{array}{l}\text { Dry Cr at Hawarden, Iowa } \\
(+0.027-\text { Skew map }\end{array}$ & $\mathrm{CR}$ & & & -of-state s & $\begin{array}{l}\text { ation used } \\
\text { lo basin cl }\end{array}$ & $\begin{array}{l}\text { only for } \mathrm{s} \\
\text { aracteristi }\end{array}$ & $\begin{array}{l}\text { kew relati } \\
\text { cs }\end{array}$ & on(s) & & & $\begin{array}{l}1926,1934 \\
1949-69\end{array}$ & 1953 & 10,900 \\
\hline 5998 & 06599800 & $\begin{array}{l}\text { Perry } \mathrm{Cr} \text { near Merrill, Iowa } \\
(-0.389 \text {-Skew map }\end{array}$ & PS & & & -of-state s & $\begin{array}{l}\text { ation used } \\
\text { Io basin cl }\end{array}$ & $\begin{array}{l}\text { only for } \mathrm{s} \\
\text { aracteristi }\end{array}$ & $\begin{array}{l}\text { kew relati } \\
\text { cs }\end{array}$ & on(s) & & & $\begin{array}{l}\text { 1953-65, } \\
1968-73, \\
1976-77\end{array}$ & 1953 & 2,540 \\
\hline 5999a & 06599950 & $\begin{array}{l}\text { Perry Cr near Hinton, Iowa } \\
(-0.200 \text {-Skew map }\end{array}$ & PS & & & -of-state s & $\begin{array}{l}\text { ation used } \\
\text { Io basin cl }\end{array}$ & $\begin{array}{l}\text { only for } \mathrm{s} \\
\text { aracteristi }\end{array}$ & ew relati & on $(\mathrm{s})$ & & & $\begin{array}{l}\text { 1953-65, } \\
1967,1969\end{array}$ & 1953 & 4,980 \\
\hline 6000 & 06600000 & $\begin{array}{l}\text { Perry } \mathrm{Cr} \text { at } 38 \text { th Street, Sioux City, Iowa } \\
(-0.308 \text {-Skew map, NE }\end{array}$ & $\mathrm{CR}$ & & & -of-state s & ation used & only for $\mathrm{s}$ & kew relati & on(s) & & & $\begin{array}{l}1939-69 \\
1981-93\end{array}$ & 1944 & 9,600 \\
\hline
\end{tabular}


Table B2. Peak-flow frequency data for streamflow-gaging stations in Nebraska and for selected out-of-state stations,

and drainage areas for regulated streams--Continued

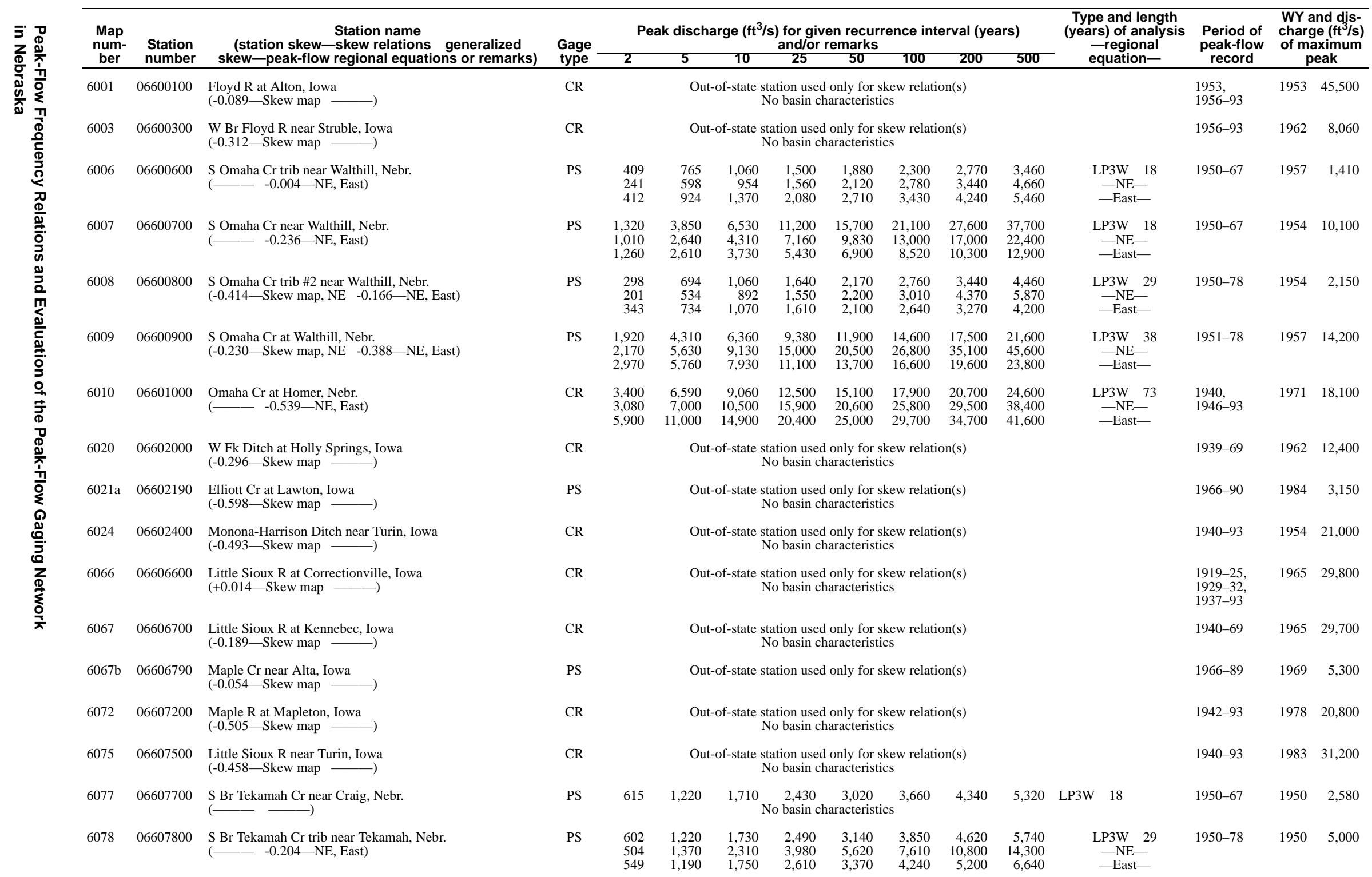


Table B2. Peak-flow frequency data for streamflow-gaging stations in Nebraska and for selected out-of-state stations,

and drainage areas for regulated streams--Continued

\begin{tabular}{|c|c|c|c|c|c|c|c|c|c|c|c|c|c|c|c|}
\hline \multirow{3}{*}{$\begin{array}{c}\begin{array}{c}\text { Map } \\
\text { num- } \\
\text { ber }\end{array} \\
6079\end{array}$} & \multirow{3}{*}{$\begin{array}{c}\begin{array}{c}\text { Station } \\
\text { number }\end{array} \\
06607900\end{array}$} & \multirow{3}{*}{$\begin{array}{l}\begin{array}{c}\text { Station name } \\
\text { (station skew-skew relations } \\
\text { skew-peak-flow regional equations or remarks) }\end{array} \\
\text { S Br Tekamah Cr near Tekamah, Nebr. } \\
\text { - }-0.401 — \text { NE, East) }\end{array}$} & \multirow{3}{*}{$\begin{array}{c}\begin{array}{c}\text { Gage } \\
\text { type }\end{array} \\
\text { PS }\end{array}$} & \multicolumn{8}{|c|}{$\begin{array}{l}\left.\text { Peak discharge ( } \mathrm{ft}^{3} / \mathrm{s}\right) \text { for given recurrence interval (years) } \\
\text { and/or remarks }\end{array}$} & \multirow{3}{*}{$\begin{array}{c}\begin{array}{c}\text { Type and length } \\
\text { (years) of analysis } \\
\text {-regional } \\
\text { equation- }\end{array} \\
\begin{array}{c}\text { LP3W } 18 \\
\text { 二NE- } \\
\text {-East- }\end{array}\end{array}$} & \multirow{3}{*}{$\begin{array}{c}\begin{array}{c}\text { Period of } \\
\text { peak-flow } \\
\text { record }\end{array} \\
1950-67\end{array}$} & \multirow{2}{*}{\multicolumn{2}{|c|}{$\begin{array}{c}\text { WY and dis- } \\
\text { charge }\left(\mathrm{ft}^{3} / \mathrm{s}\right) \\
\text { of maximum } \\
\text { peak }\end{array}$}} \\
\hline & & & & 2 & 5 & 10 & 25 & 50 & 100 & 200 & 500 & & & & \\
\hline & & & & $\begin{array}{r}1,290 \\
773 \\
436\end{array}$ & $\begin{array}{l}2,130 \\
1,990 \\
1,060\end{array}$ & $\begin{array}{l}2,720 \\
3,220 \\
1,640\end{array}$ & $\begin{array}{l}3,480 \\
5,310 \\
2,600\end{array}$ & $\begin{array}{l}4,040 \\
7,260 \\
3,500\end{array}$ & $\begin{array}{l}4,600 \\
9,520 \\
4,560\end{array}$ & $\begin{array}{r}5,160 \\
12,200 \\
5,810\end{array}$ & $\begin{array}{r}5,910 \\
16,100 \\
7,760\end{array}$ & & & 1963 & 4,560 \\
\hline 6080 & 06608000 & $\begin{array}{l}\text { Tekamah Cr at Tekamah, Nebr. } \\
(-0.651-\text { Skew map, NE }-0.473-N E \text {, East })\end{array}$ & CR & $\begin{array}{l}1,740 \\
1,060 \\
1,750\end{array}$ & $\begin{array}{l}3,730 \\
2,480 \\
3,620\end{array}$ & $\begin{array}{l}5,330 \\
3,780 \\
5,140 \\
\text { Dam on }\end{array}$ & $\begin{array}{c}7,550 \\
5,830 \\
7,390 \\
\text { S Br Teka }\end{array}$ & $\begin{array}{c}9,300 \\
7,640 \\
9,290 \\
\text { mah Cr af }\end{array}$ & $\begin{array}{r}11,100 \\
9,670 \\
11,400 \\
\text { er } 1980\end{array}$ & $\begin{array}{l}12,900 \\
11,100 \\
13,600\end{array}$ & $\begin{array}{l}15,400 \\
14,700 \\
16,800\end{array}$ & $\begin{array}{l}\text { LP3W } 31 \\
\text {-NE- } \\
\text {-East- }\end{array}$ & $1950-89$ & 1963 & 6,180 \\
\hline 6085 & 06608500 & $\begin{array}{l}\text { Soldier } \mathrm{R} \text { at Pisgah, Iowa } \\
(-0.583 \text {-Skew map, NE — }\end{array}$ & CR & & Out- & of-state st & tion used & only for sl & ew relatio & n(s) & & & $1940-93$ & 1993 & 23,400 \\
\hline 6086 & 06608600 & $\begin{array}{l}\text { New York Cr near Spiker, Nebr. } \\
(--0.168 \text {-NE, East })\end{array}$ & PS & $\begin{array}{l}459 \\
152 \\
256\end{array}$ & $\begin{array}{l}876 \\
380 \\
579\end{array}$ & $\begin{array}{r}1,220 \\
616 \\
870\end{array}$ & $\begin{array}{l}1,710 \\
1,030 \\
1,350\end{array}$ & $\begin{array}{l}2,130 \\
1,430 \\
1,790\end{array}$ & $\begin{array}{l}2,580 \\
1,920 \\
2,310\end{array}$ & $\begin{array}{l}3,070 \\
2,540 \\
2,920\end{array}$ & $\begin{array}{l}3,780 \\
3,460 \\
3,850\end{array}$ & $\begin{array}{c}\text { LP3W } 16 \\
\text {-NE- } \\
\text {-East- }\end{array}$ & $1952-67$ & 1960 & 1,700 \\
\hline 6087 & 06608700 & $\begin{array}{l}\text { New York Cr trib near Spiker, Nebr. } \\
(-0.299-\text { Skew map, NE }-0.205-\text { NE, East })\end{array}$ & PS & $\begin{array}{l}242 \\
171 \\
253\end{array}$ & $\begin{array}{l}629 \\
438 \\
566\end{array}$ & $\begin{array}{r}1,010 \\
719 \\
847\end{array}$ & $\begin{array}{l}1,660 \\
1,220 \\
1,310\end{array}$ & $\begin{array}{l}2,250 \\
1,720 \\
1,730\end{array}$ & $\begin{array}{l}2,950 \\
2,340 \\
2,220\end{array}$ & $\begin{array}{l}3,760 \\
3,270 \\
2,790\end{array}$ & $\begin{array}{l}5,020 \\
4,420 \\
3,670\end{array}$ & $\begin{array}{l}\text { LP3W } 28 \\
\text { 二NE- } \\
\text {-East- }\end{array}$ & 1951-78 & 1957 & 1,580 \\
\hline 6088 & 06608800 & $\begin{array}{l}\text { New York Cr north of Spiker, Nebr. } \\
(-0.152-\text { Skew map, NE }-0.180-N E \text {, East })\end{array}$ & PS & $\begin{array}{r}1,250 \\
379 \\
577\end{array}$ & $\begin{array}{r}2,090 \\
941 \\
1,240\end{array}$ & $\begin{array}{l}2,700 \\
1,510 \\
1,820\end{array}$ & $\begin{array}{l}3,530 \\
2,480 \\
2,740\end{array}$ & $\begin{array}{l}4,180 \\
3,410 \\
3,580\end{array}$ & $\begin{array}{l}4,840 \\
4,510 \\
4,540\end{array}$ & $\begin{array}{l}5,540 \\
5,900 \\
5,620\end{array}$ & $\begin{array}{l}6,490 \\
7,910 \\
7,260\end{array}$ & $\begin{array}{c}\mathrm{LP} 3 \mathrm{~W} \quad 25 \\
\text {-NE-East- } \\
\text { - }\end{array}$ & $1951-75$ & 1960 & 3,620 \\
\hline 6089 & 06608900 & $\begin{array}{l}\text { New York Cr east of Spiker, Nebr. } \\
(+0.213-\text { Skew map, NE }-0.322-\text { NE, East })\end{array}$ & PS & $\begin{array}{l}776 \\
697 \\
888\end{array}$ & $\begin{array}{l}2,080 \\
1,710 \\
1,880\end{array}$ & $\begin{array}{l}3,410 \\
2,710 \\
2,720\end{array}$ & $\begin{array}{l}5,730 \\
4,420 \\
4,040\end{array}$ & $\begin{array}{l}7,940 \\
6,030 \\
5,230\end{array}$ & $\begin{array}{r}10,600 \\
7,940 \\
6,580\end{array}$ & $\begin{array}{r}13,800 \\
10,400 \\
8,090\end{array}$ & $\begin{array}{l}18,800 \\
13,800 \\
10,400\end{array}$ & $\begin{array}{l}\text { LP3W } 29 \\
\text {-NE- } \\
\text {-East- }\end{array}$ & $1950-78$ & 1960 & 9,250 \\
\hline 6090 & 06609000 & $\begin{array}{l}\text { New York Cr at Herman, Nebr. } \\
(-0.369-\text { Skew map, NE }-0.322-\mathrm{NE} \text {, East })\end{array}$ & CR & $\begin{array}{l}1,400 \\
1,100 \\
1,580\end{array}$ & $\begin{array}{l}2,890 \\
2,730 \\
3,160\end{array}$ & $\begin{array}{l}4,110 \\
4,330 \\
4,460\end{array}$ & $\begin{array}{l}5,860 \\
7,040 \\
6,420\end{array}$ & $\begin{array}{l}7,290 \\
9,500 \\
8,130\end{array}$ & $\begin{array}{r}8,810 \\
12,600 \\
10,000\end{array}$ & $\begin{array}{l}10,400 \\
16,600 \\
12,100\end{array}$ & $\begin{array}{l}12,700 \\
21,800 \\
15,100\end{array}$ & $\begin{array}{l}\text { LP3W } 24 \\
\text {-NE- } \\
\text {-East- }\end{array}$ & 1946-69 & 1950 & 5,500 \\
\hline 6095 & 06609500 & $\begin{array}{l}\text { Boyer } R \text { at Logan, Iowa } \\
(-0.343-\text { Skew map }\end{array}$ & $\mathrm{CR}$ & & & -state & $\begin{array}{l}\text { on use } \\
\text { basin }\end{array}$ & $\begin{array}{l}\text { ly for } \\
\text { cteris }\end{array}$ & w rela & & & & $\begin{array}{l}1918-25, \\
1938-93\end{array}$ & 1990 & 30,800 \\
\hline $6095 \mathrm{~b}$ & 06609560 & $\begin{array}{l}\text { Willow Cr near Soldier, Iowa } \\
(-0.065 \text {-Skew map }-)\end{array}$ & PS & & Out- & of-state st & $\begin{array}{l}\text { ion us } \\
\text { basin }\end{array}$ & $\begin{array}{l}\text { ly for } \\
\text { acteris }\end{array}$ & $v$ relati & & & & $\begin{array}{l}\text { 1966-77, } \\
1979-90\end{array}$ & 1987 & 4,440 \\
\hline 6105 & 06610500 & $\begin{array}{l}\text { Indian Cr at Council Bluffs, Iowa } \\
(-0.402-\text { Skew map }\end{array}$ & CR & & Out- & of-state st & $\begin{array}{l}\text { tion used } \\
\text { basin ch }\end{array}$ & ly for $\mathrm{s}$ & relatio & & & & 1955-76 & 1965 & 2,980 \\
\hline 6106 & 06610600 & $\begin{array}{l}\text { Mosquito Cr at Neola, Iowa } \\
(-0.065-\text { Skew map } \\
\longrightarrow\end{array}$ & PS & & Out- & of-state st & tion used & only for $\mathrm{s}$ & ew relatio & $\mathrm{n}(\mathrm{s})$ & & & 1952-90 & 1958 & 17,300 \\
\hline 6107 & 06610700 & $\begin{array}{l}\text { Big Papillion Cr near Orum, Nebr. } \\
\left(\frac{-0.250-\text { New station for NE and East network }}{\text { analyses })}\right.\end{array}$ & PS & $\begin{array}{l}303 \\
384 \\
610\end{array}$ & $\begin{array}{r}677 \\
927 \\
1,320\end{array}$ & $\begin{array}{l}1,010 \\
1,450 \\
1,940\end{array}$ & $\begin{array}{l}1,510 \\
2,340 \\
2,940\end{array}$ & $\begin{array}{l}1,930 \\
3,180 \\
3,860\end{array}$ & $\begin{array}{l}2,410 \\
4,140 \\
4,890\end{array}$ & $\begin{array}{l}2,920 \\
5,180 \\
6,090\end{array}$ & $\begin{array}{l}3,680 \\
6,960 \\
7,870\end{array}$ & $\begin{array}{l}\text { LP3W } 11 \\
\text {-NE- } \\
\text {-East- }\end{array}$ & 1968-78 & 1971 & 800 \\
\hline 6524 & 06652400 & $\begin{array}{l}\text { Watson Draw near Lost Springs, Wyo. } \\
(--0.159-\mathrm{N} \& \mathrm{~W})\end{array}$ & PS & $\begin{array}{l}42 \\
45\end{array}$ & $\begin{array}{l}162 \\
186\end{array}$ & $\begin{array}{l}326 \\
356\end{array}$ & $\begin{array}{l}667 \\
663\end{array}$ & $\begin{array}{r}1,050 \\
968\end{array}$ & $\begin{array}{l}1,550 \\
1,640\end{array}$ & $\begin{array}{l}2,220 \\
2,160\end{array}$ & $\begin{array}{l}3,380 \\
2,970\end{array}$ & $\begin{array}{l}\mathrm{LP} 3 \mathrm{~W} \\
-\mathrm{N} \& \mathrm{~W}-\end{array}$ & $1960-84$ & 1961 & 2,100 \\
\hline 6745 & 06674500 & $\begin{array}{l}\text { N Platte } \mathrm{R} \text { at Nebraska-Wyoming state line } \\
\left(22,200 \mathrm{mi}^{2}, \text { of which } 1,930 \mathrm{mi}^{2} \text { is probably noncontributing }\right.\end{array}$ & $\underset{\mathrm{g}-\mathrm{moc}}{\mathrm{CR}}$ & $\begin{array}{l}2,410 \\
\text { fied from }\end{array}$ & $\begin{array}{l}4,140 \\
\text { Boohar an }\end{array}$ & $\begin{array}{l}5,810 \\
\text { d others, }\end{array}$ & $\begin{array}{l}8,730 \\
992)\end{array}$ & 11,700 & 15,400 & 20,200 & 28,500 & REG 36 & 1929-93 & 1929 & 17,900 \\
\hline 6775 & 06677500 & $\begin{array}{l}\text { Horse Cr near Lyman, Nebr. } \\
(+0.286-\mathrm{HP}, \mathrm{N} \& \mathrm{~W}+0.025-\mathrm{HPS}, \mathrm{N} \& \mathrm{~W})\end{array}$ & CR & $\begin{array}{r}745 \\
494 \\
1,480\end{array}$ & $\begin{array}{r}1,390 \\
983 \\
3,210\end{array}$ & $\begin{array}{l}1,940 \\
1,390 \\
4,560\end{array}$ & $\begin{array}{l}2,770 \\
2,110 \\
6,400\end{array}$ & $\begin{array}{l}3,510 \\
2,730 \\
7,930\end{array}$ & $\begin{array}{l}4,340 \\
3,520 \\
6,370\end{array}$ & $\begin{array}{l}5,290 \\
4,450 \\
7,610\end{array}$ & $\begin{array}{l}6,740 \\
5,910 \\
9,450\end{array}$ & $\begin{array}{l}\text { LP3W } 63 \\
\text { - } \mathrm{HPS}- \\
\text {-N\&W- }\end{array}$ & 1931-93 & 1967 & 5,110 \\
\hline
\end{tabular}


Table B2. Peak-flow frequency data for streamflow-gaging stations in Nebraska and for selected out-of-state stations,

and drainage areas for regulated streams--Continued

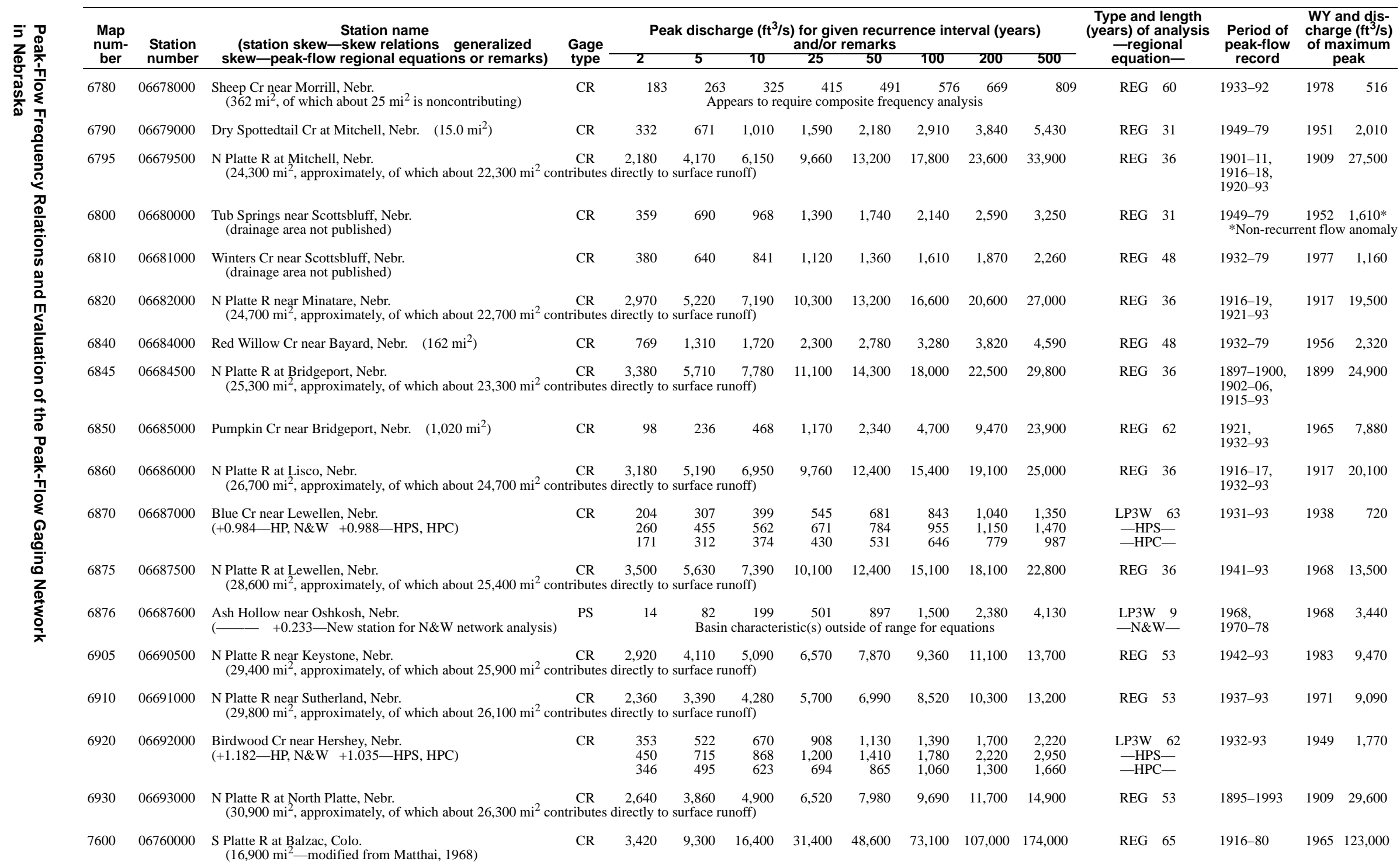


Table B2. Peak-flow frequency data for streamflow-gaging stations in Nebraska and for selected out-of-state stations,

and drainage areas for regulated streams--Continued

\begin{tabular}{|c|c|c|c|c|c|c|c|c|c|c|c|c|c|c|c|c|}
\hline \multirow{2}{*}{$\begin{array}{c}\begin{array}{c}\text { Map } \\
\text { num- } \\
\text { ber }\end{array} \\
7619\end{array}$} & \multirow{2}{*}{$\begin{array}{c}\begin{array}{c}\text { Station } \\
\text { number }\end{array} \\
06761900\end{array}$} & \multirow{3}{*}{$\begin{array}{l}\begin{array}{c}\text { Station name } \\
\text { (station skew_-skew relations generalized } \\
\text { skew—-peak-flow regional equations or remarks) }\end{array} \\
\begin{array}{l}\text { Lodgepole Cr trib near Pine Bluffs, Wyo. } \\
(+0.090-\text { Skew map }-)\end{array} \\
\text { Lodgepole Cr at Bushnell, Nebr. } \quad\left(1,350 \mathrm{mi}^{2}\right)\end{array}$} & \multirow{3}{*}{$\begin{array}{l}\begin{array}{c}\text { Gage } \\
\text { type }\end{array} \\
\text { PS } \\
\text { CR }\end{array}$} & \multicolumn{8}{|c|}{$\begin{array}{c}\text { Peak discharge }\left(\mathrm{ft}^{3} / \mathbf{s}\right) \text { for given recurrence interval (years) } \\
\text { and/or remarks }\end{array}$} & \multirow{2}{*}{\multicolumn{2}{|c|}{$\begin{array}{c}\text { Type and length } \\
\text { (years) of analysis } \\
\text {-regional } \\
\text { equation- }\end{array}$}} & \multirow{3}{*}{$\begin{array}{c}\begin{array}{c}\text { Period of } \\
\text { peak-flow } \\
\text { record }\end{array} \\
1960-81 \\
1932-92\end{array}$} & \multicolumn{2}{|c|}{$\begin{array}{c}\text { WY and dis- } \\
\text { charge }\left(\mathrm{ft}^{3} / \mathrm{s}\right) \\
\text { of maximum } \\
\text { peak }\end{array}$} \\
\hline & & & & 2 & & $\frac{10}{\text { t-of-state sta }}$ & $\begin{array}{l}\text { ion used } \\
\text { basin ch }\end{array}$ & $\begin{array}{l}\text { only fo } \\
\text { aracteri }\end{array}$ & \multicolumn{2}{|c|}{$\frac{100 \quad 200}{\text { kew relation(s) }}$} & \multirow{2}{*}{$\begin{array}{r}500 \\
70,200\end{array}$} & & & & 1981 & 158 \\
\hline 7625 & 06762500 & & & 195 & 924 & 2,200 & 5,770 & 11,000 & 20,000 & 35,000 & & \multirow[t]{2}{*}{ REG } & \multirow[t]{2}{*}{61} & & 1950 & 16,500 \\
\hline 7626 & 06762600 & $\begin{array}{l}\text { Lodgepole Cr trib \#2 near Albin, Wyo. } \\
(-0.386 \text { - Skew map, HP, N\&W }\end{array}$ & PS & \multicolumn{8}{|c|}{$\begin{array}{l}\text { Out-of-state station used only for skew relation(s) } \\
\text { Basin characteristic(s) outside of range for equations }\end{array}$} & & & $1960-84$ & 1967 & 528 \\
\hline 7632 & 06763200 & $\begin{array}{l}\text { Lodgepole Cr trib near Sunol, Nebr. } \\
\left(\begin{array}{r}r \\
-0.067-\text { New station for N\&W network analysis })\end{array}\right.\end{array}$ & PS & \multicolumn{8}{|c|}{$\begin{array}{l}\text { Insufficient data-zero flow for } 8 \text { of } 11 \text { peaks } \\
\text { Basin characteristic(s) outside of range for equations }\end{array}$} & \multicolumn{2}{|c|}{$-\mathrm{N} \& \mathrm{~W}-$} & 1968-78 & 1968 & 820 \\
\hline 7635 & 06763500 & Lodgepole $\mathrm{Cr}$ near Ralton, Nebr. $\quad\left(3,310 \mathrm{mi}^{2}\right)$ & $\mathrm{CR}$ & 50 & 176 & 423 & 1,290 & 2,920 & 6,540 & 14,500 & 41,100 & REG & & $\begin{array}{l}1931, \\
1951-79\end{array}$ & 1968 & 4,560 \\
\hline 7640 & 06764000 & $\begin{array}{l}\text { S Platte R at Julesburg, Colo. } \\
\left(23,200 \mathrm{mi}^{2}-\text { modified from Ugland and others, 1994) }\right.\end{array}$ & $\mathrm{CR}$ & 2,870 & 7,970 & 14,000 & 25,900 & 39,000 & 56,700 & 80,500 & 124,000 & REG & 49 & $\begin{array}{l}1902, \\
1906-07 \\
1948-93\end{array}$ & 1965 & 37,600 \\
\hline 7648a & 06764880 & S Platte R at Roscoe, Nebr. (drainage area not published) & $\mathrm{CR}$ & 3,380 & 6,760 & 10,000 & 15,700 & 21,400 & 28,400 & 37,100 & 52,000 & REG & 11 & $1983-93$ & 1983 & 14,700 \\
\hline 7650 & 06765000 & S Platte R at Paxton, Nebr. $\quad\left(24,000 \mathrm{mi}^{2}\right)$ & $\mathrm{CR}$ & 1,700 & 6,670 & 13,000 & 25,500 & 38,800 & 55,700 & 76,900 & 112,000 & REG & 30 & $1940-1969$ & 1965 & 33,800 \\
\hline 7655 & 06765500 & $\begin{array}{l}\text { S Platte R at North Platte, Nebr. } \\
\left(24,300 \mathrm{mi}^{2} \text {, approximately }\right)\end{array}$ & CR & 2,330 & 6,920 & 12,500 & 23,800 & 36,400 & 53,800 & 77,200 & 120,000 & REG & 77 & $\begin{array}{l}\text { 1897, } \\
\text { 1914-15, } \\
1917, \\
1921-93\end{array}$ & 1935 & 37,100 \\
\hline 7660 & 06766000 & $\begin{array}{l}\text { Platte } \mathrm{R} \text { at Brady, Nebr. } \\
\left(56,200 \mathrm{mi}^{2} \text {, approximately, of which about } 51,400 \mathrm{mi}^{2} \text { con }\right.\end{array}$ & $\begin{array}{l}\mathrm{CR} \\
\text { tributes }\end{array}$ & $\begin{array}{l}3,430 \\
\text { directly to }\end{array}$ & $\begin{array}{l}7,090 \\
\text { surface ru }\end{array}$ & $\begin{array}{c}10,900 \\
\text { noff) }\end{array}$ & 18,000 & 25,400 & 35,100 & 48,000 & 71,100 & REG & 53 & $1938-93$ & 1983 & 23,500 \\
\hline 7665 & 06766500 & $\begin{array}{l}\text { Platte } \mathrm{R} \text { near Cozad, Nebr. } \\
\left(56,500 \mathrm{mi}^{2} \text {, approximately, of which about } 51,700 \mathrm{mi}^{2} \text { con }\right.\end{array}$ & $\begin{array}{l}\mathrm{CR} \\
\text { tributes }\end{array}$ & $\begin{array}{l}3,240 \\
\text { directly to }\end{array}$ & $\begin{array}{l}7,560 \\
\text { surface ru }\end{array}$ & $\begin{array}{c}11,700 \\
\text { noff) }\end{array}$ & 18,600 & 25,100 & 32,700 & 41,600 & 55,800 & REG & 52 & 1940-92 & 1983 & 21,500 \\
\hline 7670 & 06767000 & Platte R near Lexington, Nebr. $\quad\left(61,300 \mathrm{mi}^{2}\right)$ & Staff & 15,700 & 24,600 & 30,100 & 36,500 & 40,900 & 45,000 & 48,800 & 53,400 & REG & 8 & $\begin{array}{l}\text { 1902, } \\
1904-06 \\
1916-24\end{array}$ & 1921 & 35,600 \\
\hline 7671 & 06767100 & $\begin{array}{l}\text { S Fk Plum Cr trib near Farnam, Nebr. } \\
(--0.145-\mathrm{N} \& \mathrm{~W})\end{array}$ & PS & $\begin{array}{r}196 \\
74\end{array}$ & $\begin{array}{l}535 \\
323\end{array}$ & $\begin{array}{l}885 \\
654\end{array}$ & $\begin{array}{l}1,490 \\
1,320\end{array}$ & $\begin{array}{l}2,070 \\
2,030\end{array}$ & $\begin{array}{l}2,760 \\
3,640\end{array}$ & $\begin{array}{l}3,580 \\
5,130\end{array}$ & $\begin{array}{l}4,880 \\
7,670\end{array}$ & $\begin{array}{ll}\mathrm{LP} 3 \mathrm{~W} \\
-\mathrm{N} \& \mathrm{~V}\end{array}$ & & $1951-70$ & 1962 & 2,320 \\
\hline 7672 & 06767200 & $\begin{array}{l}\text { N Fk Plum Cr trib near Farnam, Nebr. } \\
(-0.062-\text { Skew map }-0.144-\mathrm{N} \& \mathrm{~W})\end{array}$ & PS & $\begin{array}{l}22 \\
28\end{array}$ & $\begin{array}{r}71 \\
153\end{array}$ & $\begin{array}{l}127 \\
342\end{array}$ & $\begin{array}{l}234 \\
749\end{array}$ & $\begin{array}{r}344 \\
1,210\end{array}$ & $\begin{array}{r}486 \\
1,910\end{array}$ & $\begin{array}{r}664 \\
2,760\end{array}$ & $\begin{array}{r}964 \\
4,210\end{array}$ & $\begin{array}{l}\text { LP3W } \\
-\mathrm{N} \& \mathrm{~V}\end{array}$ & & $1952-78$ & 1962 & 435 \\
\hline 7673 & 06767300 & $\begin{array}{l}\text { Plum Cr trib at Farnam, Nebr. } \\
(-0.010-\text { Skew map }-0.144-\mathrm{N} \& \mathrm{~W})\end{array}$ & PS & $\begin{array}{r}95 \\
116\end{array}$ & $\begin{array}{l}618 \\
468\end{array}$ & $\begin{array}{r}1,610 \\
914\end{array}$ & $\begin{array}{l}4,430 \\
1,770\end{array}$ & $\begin{array}{l}8,430 \\
2,660\end{array}$ & $\begin{array}{r}15,000 \\
3,830\end{array}$ & $\begin{array}{r}25,200 \\
5,320\end{array}$ & $\begin{array}{r}47,100 \\
7,790\end{array}$ & $\begin{array}{l}\mathrm{LP} 3 \mathrm{~W} \\
-\mathrm{N} \& \mathrm{~V}\end{array}$ & $\begin{array}{l}46 \\
N-\end{array}$ & $\begin{array}{l}1947-48 \\
1951-70\end{array}$ & 1962 & 3,110 \\
\hline 7674 & 06767400 & $\begin{array}{l}\text { N Plum Cr near Farnam, Nebr. } \\
(-0.434-\text { Skew map }-0.150-N \& W)\end{array}$ & PS & $\begin{array}{r}68 \\
143\end{array}$ & $\begin{array}{l}361 \\
519\end{array}$ & $\begin{array}{l}829 \\
983\end{array}$ & $\begin{array}{l}1,960 \\
1,890\end{array}$ & $\begin{array}{l}3,350 \\
2,830\end{array}$ & $\begin{array}{l}5,390 \\
6,070\end{array}$ & $\begin{array}{l}8,250 \\
8,460\end{array}$ & $\begin{array}{l}13,700 \\
12,400\end{array}$ & $\begin{array}{l}\mathrm{LP} 3 \mathrm{~W} \\
-\mathrm{N} \& \mathrm{~V}\end{array}$ & & $\begin{array}{l}1947, \\
1951-70\end{array}$ & 1962 & 1,600 \\
\hline 7674b & 06767410 & $\begin{array}{l}\text { Plum Cr near Farnam, Nebr. } \\
(-0.279-\text { Skew map }-0.148-\mathrm{N} \& \mathrm{~W})\end{array}$ & PS & $\begin{array}{l}159 \\
231\end{array}$ & $\begin{array}{l}722 \\
768\end{array}$ & $\begin{array}{l}1,540 \\
1,390\end{array}$ & $\begin{array}{l}3,390 \\
2,560\end{array}$ & $\begin{array}{l}5,560 \\
3,740\end{array}$ & $\begin{array}{l}8,610 \\
6,580\end{array}$ & $\begin{array}{r}12,800 \\
8,990\end{array}$ & $\begin{array}{l}20,400 \\
13,000\end{array}$ & $\begin{array}{l}\mathrm{LP} 3 \mathrm{~W} \\
-\mathrm{N} \& \mathrm{~V}\end{array}$ & $\mathrm{~N}-$ & $\begin{array}{l}\text { 1947, } \\
1951-78\end{array}$ & 1962 & 1,970 \\
\hline 7675 & 06767500 & $\begin{array}{l}\text { Plum Cr near Smithfield, Nebr. } \\
(+0.081-\text { Skew map }-0.160-\mathrm{N} \& \mathrm{~W})\end{array}$ & $\mathrm{CR}$ & $\begin{array}{l}384 \\
393\end{array}$ & $\begin{array}{r}937 \\
1,150\end{array}$ & $\begin{array}{l}1,450 \\
1,980\end{array}$ & $\begin{array}{l}2,270 \\
3,490\end{array}$ & $\begin{array}{l}3,000 \\
4,970\end{array}$ & $\begin{array}{l}3,820 \\
6,940\end{array}$ & $\begin{array}{l}4,750 \\
9,200\end{array}$ & $\begin{array}{r}6,120 \\
12,800\end{array}$ & $\begin{array}{l}\mathrm{LP} 3 \mathrm{~W} \\
-\mathrm{N} \& \mathrm{~V}\end{array}$ & & $1947-78$ & 1947 & 2,800 \\
\hline 7680 & 06768000 & $\begin{array}{l}\text { Platte R near Overton, Nebr. } \\
\left(56,300 \mathrm{mi}^{2} \text {, approximately, of which about } 51,600 \mathrm{mi}^{2} \mathrm{c}\right.\end{array}$ & $\begin{array}{l}\text { CR } \\
\text { ibutes }\end{array}$ & $\begin{array}{l}5,270 \\
\text { rectly to }\end{array}$ & $\begin{array}{l}9,250 \\
\text { urface ru }\end{array}$ & $\begin{array}{l}12,800 \\
\text { off) }\end{array}$ & 18,700 & 24,100 & 30,700 & 38,600 & 51,400 & REG & 53 & $1915-93$ & 1935 & 37,600 \\
\hline
\end{tabular}


Table B2. Peak-flow frequency data for streamflow-gaging stations in Nebraska and for selected out-of-state stations,

and drainage areas for regulated streams--Continued

\begin{tabular}{|c|c|c|c|c|c|c|c|c|c|c|c|c|c|c|c|}
\hline \multirow{3}{*}{ 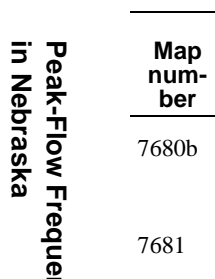 } & \multirow{2}{*}{$\begin{array}{c}\begin{array}{c}\text { Station } \\
\text { number }\end{array} \\
06768050\end{array}$} & \multirow{2}{*}{$\begin{array}{c}\begin{array}{c}\text { Station name } \\
\text { (station skew_-skew relations } \\
\text { skew-peak-flow regional equations or remarks) }\end{array} \\
\text { Buffalo Cr trib \#1 near Buffalo, Nebr. } \\
(-\quad-330 \text {-New station for C\&SC network analysis) }\end{array}$} & \multirow{2}{*}{$\begin{array}{c}\begin{array}{c}\text { Gage } \\
\text { type }\end{array} \\
\text { PS }\end{array}$} & \multicolumn{8}{|c|}{$\begin{array}{l}\text { Peak discharge }\left(\mathrm{ft}^{3} / \mathrm{s}\right) \text { for given recurrence interval (years) } \\
\text { and/or remarks }\end{array}$} & \multirow{2}{*}{$\begin{array}{c}\begin{array}{c}\text { Type and length } \\
\text { (years) of analysis } \\
\text {-regional } \\
\text { equation- }\end{array} \\
\text { LP3W } 14 \\
\text { - C\&SC- }\end{array}$} & \multirow{2}{*}{$\begin{array}{c}\begin{array}{c}\text { Period of } \\
\text { peak-flow } \\
\text { record }\end{array} \\
1965-78\end{array}$} & \multicolumn{2}{|c|}{$\begin{array}{c}\text { WY and dis- } \\
\text { charge }\left(\mathrm{ft}^{3} / \mathrm{s}\right) \\
\text { of maximum } \\
\text { peak }\end{array}$} \\
\hline & & & & $\begin{array}{l}13 \\
14\end{array}$ & $\begin{array}{l}66 \\
45 \\
\text { Аpp }\end{array}$ & $\begin{array}{r}144 \\
77 \\
\text { pears to re }\end{array}$ & $\begin{array}{c}317 \\
131 \\
\text { equire com }\end{array}$ & $\begin{array}{c}515 \\
184 \\
\text { oosite frequ }\end{array}$ & $\begin{array}{c}787 \\
243 \\
\text { ncy anal }\end{array}$ & $\begin{array}{r}1,140 \\
311 \\
\text { ysis }\end{array}$ & $\begin{array}{r}1,780 \\
419\end{array}$ & & & 1968 & 243 \\
\hline & 06768100 & $\begin{array}{l}\text { East Buffalo Cr near Buffalo, Nebr. } \\
(-0.587-\text { Skew map }-0.320 \text { - C\&SC) }\end{array}$ & PS & $\begin{array}{l}18 \\
13\end{array}$ & 66 & $\begin{array}{ll} & 122 \\
7 & 115\end{array}$ & $\begin{array}{l}222 \\
232\end{array}$ & $\begin{array}{l}320 \\
357\end{array}$ & $\begin{array}{l}436 \\
519\end{array}$ & $\begin{array}{l}572 \\
722\end{array}$ & $\begin{array}{r}782 \\
1,060\end{array}$ & $\underset{-\mathrm{CP} 3 \mathrm{~W}}{\mathrm{LSC}-}$ & $1951-78$ & 1958 & 208 \\
\hline$\stackrel{\text { P }}{\stackrel{2}{P}}$ & 06768200 & $\begin{array}{l}\text { Buffalo } \mathrm{Cr} \text { at Buffalo, Nebr. } \\
(--0.330-\mathrm{C} \& \mathrm{SC})\end{array}$ & PS & $\begin{array}{l}85 \\
96\end{array}$ & $\begin{array}{l}345 \\
306\end{array}$ & $\begin{array}{l}673 \\
534\end{array}$ & $\begin{array}{r}1,300 \\
941\end{array}$ & $\begin{array}{l}1,950 \\
1,340\end{array}$ & $\begin{array}{l}2,750 \\
1,820\end{array}$ & $\begin{array}{l}3,720 \\
2,380\end{array}$ & $\begin{array}{l}5,260 \\
3,270\end{array}$ & $\begin{array}{l}\mathrm{LP} 3 \mathrm{~W} \\
-\mathrm{C} \& \mathrm{SC}-\end{array}$ & $1951-67$ & 1958 & 1,570 \\
\hline क्ञ & 06768300 & $\begin{array}{l}\text { Buffalo Cr trib \#2 near Buffalo, Nebr. } \\
(-\stackrel{-}{-}\end{array}$ & PS & $\begin{array}{c}24 \\
\text { Appears }\end{array}$ & $\begin{array}{l}102 \\
\text { to require c }\end{array}$ & $\begin{array}{r}203 \\
\text { composit }\end{array}$ & $\begin{array}{l}404 \\
\text { efrequenc } \\
\text { No basin ch }\end{array}$ & $\begin{array}{l}613 \\
\text { analysis } \\
\text { racteristic }\end{array}$ & $\begin{array}{l}876 \\
\text { zero flo }\end{array}$ & $\begin{array}{l}1,200 \\
w \text { for } 6 \text { of }\end{array}$ & $\begin{array}{c}1,710 \\
15 \text { peaks }\end{array}$ & LP3W 15 & $1951-65$ & 1958 & 172 \\
\hline$\frac{2}{20}$ & 06768400 & $\begin{array}{l}\text { W Buffalo Cr near Buffalo, Nebr. } \\
(+0.399-\text { Skew map }-0.320-\text { C\&SC) }\end{array}$ & PS & $\begin{array}{l}37 \\
39\end{array}$ & $\begin{array}{l}126 \\
155\end{array}$ & $\begin{array}{l}225 \\
298\end{array}$ & $\begin{array}{l}400 \\
577\end{array}$ & $\begin{array}{l}567 \\
866\end{array}$ & $\begin{array}{r}765 \\
1,230\end{array}$ & $\begin{array}{r}994 \\
1,680\end{array}$ & $\begin{array}{l}1,350 \\
2,410\end{array}$ & $\begin{array}{l}\mathrm{LP} 3 \mathrm{~W} \\
-\mathrm{C} \& \mathrm{SC}-\end{array}$ & $1951-78$ & 1958 & 479 \\
\hline 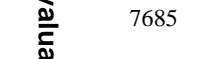 & 06768500 & 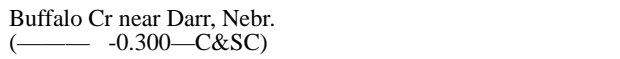 & $\mathrm{CR}$ & $\begin{array}{l}217 \\
108\end{array}$ & $\begin{array}{l}703 \\
344\end{array}$ & $\begin{array}{r}1,270 \\
601\end{array}$ & $\begin{array}{l}2,360 \\
1,060\end{array}$ & $\begin{array}{l}3,500 \\
1,500\end{array}$ & $\begin{array}{l}4,950 \\
2,030\end{array}$ & $\begin{array}{l}6,770 \\
2,660\end{array}$ & $\begin{array}{l}9,840 \\
3,630\end{array}$ & $\begin{array}{l}\text { LP3W } \\
-\mathrm{C} \& \mathrm{SC}-\end{array}$ & $1947-69$ & 1947 & 9,000 \\
\hline 7690 & 06769000 & 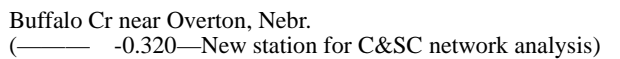 & $\mathrm{CR}$ & $\begin{array}{l}136 \\
182\end{array}$ & $\begin{array}{l}253 \\
535\end{array}$ & $\begin{array}{l}341 \\
890\end{array}$ & $\begin{array}{r}461 \\
1,520\end{array}$ & $\begin{array}{r}555 \\
2,130\end{array}$ & $\begin{array}{r}652 \\
2,840\end{array}$ & $\begin{array}{r}750 \\
3,630\end{array}$ & $\begin{array}{r}885 \\
4,890\end{array}$ & $\begin{array}{l}\mathrm{LP} 3 \mathrm{~W} \\
-\mathrm{C} \& \mathrm{SC}-\end{array}$ & $1949-58$ & 1958 & 383 \\
\hline 7691 & 06769100 & $\begin{array}{l}\text { Elm } \mathrm{Cr} \text { trib near Overton, Nebr. } \\
(-0.480 \text {-Skew map } \longrightarrow)\end{array}$ & PS & 57 & 99 & 129 & $\begin{array}{c}168 \\
\text { No basin ch }\end{array}$ & $\begin{array}{c}198 \\
\text { aracteristic }\end{array}$ & 227 & 256 & 294 & LP3W 28 & $1951-78$ & 1965 & 148 \\
\hline 7692 & 06769200 & $\begin{array}{l}\text { Elm Cr near Sumner, Nebr. } \\
(-0.359-\text { Skew map }-0.330-\text { C\&SC })\end{array}$ & PS & $\begin{array}{l}45 \\
59\end{array}$ & $\begin{array}{l}177 \\
155\end{array}$ & $\begin{array}{l}344 \\
243\end{array}$ & $\begin{array}{l}673 \\
382\end{array}$ & $\begin{array}{r}1,020 \\
507\end{array}$ & $\begin{array}{r}1,450 \\
650\end{array}$ & $\begin{array}{r}1,990 \\
811\end{array}$ & $\begin{array}{l}2,880 \\
1,050\end{array}$ & $\begin{array}{l}\mathrm{LP} 3 \mathrm{~W} \\
-\mathrm{C} \& \mathrm{SC}-\end{array}$ & $1951-78$ & 1965 & 1,660 \\
\hline 7693 & 06769300 & $\begin{array}{l}\text { Elm Cr trib \#2 near Overton, Nebr. } \\
(-0.114 \text {-Skew map } \longrightarrow)\end{array}$ & PS & 183 & 311 & 400 & $\begin{array}{c}515 \\
\text { No basin ch }\end{array}$ & $\begin{array}{c}601 \\
\text { aracteristic }\end{array}$ & 687 & 771 & 883 & LP3W 28 & $1951-78$ & 1965 & 679 \\
\hline 7695 & 06769500 & $\begin{array}{l}\text { Elm Cr near Overton, Nebr. } \\
(-\quad-0.330-\text { New station for C\&SC network analysis })\end{array}$ & $\mathrm{CR}$ & $\begin{array}{l}305 \\
153\end{array}$ & $\begin{array}{r}1,440 \\
334\end{array}$ & $\begin{array}{r}3,100 \\
477\end{array}$ & $\begin{array}{r}6,790 \\
688\end{array}$ & $\begin{array}{r}11,100 \\
871\end{array}$ & $\begin{array}{r}17,000 \\
1,060\end{array}$ & $\begin{array}{r}25,000 \\
1,260\end{array}$ & $\begin{array}{r}39,300 \\
1,560\end{array}$ & $\begin{array}{l}\mathrm{LP} 3 \mathrm{~W} \\
-\mathrm{C} \& \mathrm{SC}-\end{array}$ & $1947-58$ & 1947 & 8,000 \\
\hline 7700 & 06770000 & $\begin{array}{l}\text { Platte } R \text { near Odessa, Nebr. } \\
\left(58,100 \mathrm{mi}^{2} \text {, approximately, of which about } 55,300 \mathrm{mi}^{2} \text { cont }\right.\end{array}$ & $\begin{array}{l}\mathrm{CR} \\
\text { tributes }\end{array}$ & $\begin{array}{l}5,710 \\
\text { directly to }\end{array}$ & $\begin{array}{l}10,200 \\
\text { surface run }\end{array}$ & $\begin{array}{l}13,800 \\
\text { unoff) }\end{array}$ & 19,200 & 23,800 & 28,900 & 34,600 & 43,100 & REG 53 & $1937-93$ & 1983 & 22,900 \\
\hline 7702 & 06770200 & $\begin{array}{l}\text { Platte } \mathrm{R} \text { near Kearney, Nebr. } \\
\left(57,300 \mathrm{mi}^{2} \text {, approximately, of which about } 52,500 \mathrm{mi}^{2} \text { cont }\right.\end{array}$ & $\begin{array}{l}\mathrm{CR} \\
\text { tributes }\end{array}$ & $\begin{array}{l}5,970 \\
\text { directly to }\end{array}$ & $\begin{array}{l}10,500 \\
\text { surface run }\end{array}$ & $\begin{array}{l}14,900 \\
\text { unoff) }\end{array}$ & 22,400 & 29,800 & 39,200 & 51,000 & 71,400 & REG 12 & $1982-93$ & 1983 & 23,700 \\
\hline 7705 & 06770500 & $\begin{array}{l}\text { Platte } \mathrm{R} \text { near Grand Island, Nebr. } \\
\left(57,600 \mathrm{mi}^{2} \text {, approximately, of which about } 52,900 \mathrm{mi}^{2} \text { cont }\right.\end{array}$ & $\begin{array}{l}\mathrm{CR} \\
\text { tributes }\end{array}$ & $\begin{array}{l}6,310 \\
\text { directly to }\end{array}$ & $\begin{array}{l}10,800 \\
\text { surface run }\end{array}$ & $\begin{array}{l}13,800 \\
\text { unoff) }\end{array}$ & 19,200 & 23,800 & 28,900 & 34,600 & 43,000 & REG 53 & 1934-93 & 1935 & 30,000 \\
\hline 7706 & 06770600 & $\begin{array}{l}\text { Wood R trib near Lodi, Nebr. } \\
(-0.793 \text {-Skew map }-0.325-\text { C\&SC) }\end{array}$ & PS & $\begin{array}{l}10 \\
11\end{array}$ & $\begin{array}{l}37 \\
53\end{array}$ & $\begin{array}{r}67 \\
111\end{array}$ & $\begin{array}{l}124 \\
231\end{array}$ & $\begin{array}{l}179 \\
364\end{array}$ & $\begin{array}{l}245 \\
540\end{array}$ & $\begin{array}{l}323 \\
765\end{array}$ & $\begin{array}{r}444 \\
1,150\end{array}$ & $\begin{array}{l}\text { LP3W } 27 \\
-\mathrm{C} \& \mathrm{SC}-\end{array}$ & $1952-78$ & 1972 & 100 \\
\hline 7707 & 06770700 & $\begin{array}{l}\text { Wood R near Lodi, Nebr. } \\
(-0.436 \text {-Skew map }-0.330-\text { C\&SC) }\end{array}$ & PS & $\begin{array}{l}20 \\
37\end{array}$ & $\begin{array}{r}78 \\
134\end{array}$ & $\begin{array}{l}147 \\
248\end{array}$ & $\begin{array}{l}277 \\
463\end{array}$ & $\begin{array}{l}408 \\
680\end{array}$ & $\begin{array}{l}568 \\
950\end{array}$ & $\begin{array}{r}760 \\
1,280\end{array}$ & $\begin{array}{l}1,060 \\
1,800\end{array}$ & $\begin{array}{l}\text { LP3W } \\
-\mathrm{C} \& \mathrm{SC}-\end{array}$ & $1952-78$ & 1978 & 194 \\
\hline 7708 & 06770800 & $\begin{array}{l}\text { Wood R near Oconto, Nebr. } \\
(-0.985 \text {-Skew map }-0.330-\text { C\&SC) }\end{array}$ & PS & $\begin{array}{l}168 \\
106\end{array}$ & $\begin{array}{l}428 \\
329\end{array}$ & $\begin{array}{l}666 \\
569\end{array}$ & $\begin{array}{r}1,030 \\
996\end{array}$ & $\begin{array}{l}1,340 \\
1,410\end{array}$ & $\begin{array}{l}1,680 \\
1,910\end{array}$ & $\begin{array}{l}2,050 \\
2,500\end{array}$ & $\begin{array}{l}2,570 \\
3,420\end{array}$ & $\begin{array}{l}\text { LP3W } 29 \\
-\mathrm{C} \& \mathrm{SC}-\end{array}$ & $1952-78$ & 1954 & 790 \\
\hline 7709 & 06770900 & $\begin{array}{l}\text { Wood R at Oconto, Nebr. } \\
(-0.375-\text { Skew map }-0.330-\text { C\&SC })\end{array}$ & PS & $\begin{array}{l}117 \\
159\end{array}$ & $\begin{array}{l}371 \\
470\end{array}$ & $\begin{array}{l}648 \\
794\end{array}$ & $\begin{array}{l}1,140 \\
1,360\end{array}$ & $\begin{array}{l}1,600 \\
1,900\end{array}$ & $\begin{array}{l}2,160 \\
2,540\end{array}$ & $\begin{array}{l}2,820 \\
3,290\end{array}$ & $\begin{array}{l}3,840 \\
4,460\end{array}$ & $\begin{array}{l}\text { LP3W } \\
-\mathrm{C} \& \mathrm{SC}-\end{array}$ & 1952-78 & 1958 & 2,390 \\
\hline $7709 \mathrm{~b}$ & 06770910 & $\begin{array}{l}\text { Wood R near Lomax, Nebr. } \\
(-0.479-\text { Skew map }-0.340-\text { C\&SC })\end{array}$ & PS & $\begin{array}{l}189 \\
197\end{array}$ & $\begin{array}{l}606 \\
573\end{array}$ & $\begin{array}{r}1,060 \\
963\end{array}$ & $\begin{array}{l}1,860 \\
1,630\end{array}$ & $\begin{array}{l}2,630 \\
2,270\end{array}$ & $\begin{array}{l}3,530 \\
3,030\end{array}$ & $\begin{array}{l}4,590 \\
3,900\end{array}$ & $\begin{array}{l}6,210 \\
5,250\end{array}$ & $\begin{array}{l}\text { LP3W } 27 \\
-\mathrm{C} \& \mathrm{SC}-\end{array}$ & $1952-78$ & 1960 & 1,750 \\
\hline
\end{tabular}


Table B2. Peak-flow frequency data for streamflow-gaging stations in Nebraska and for selected out-of-state stations,

and drainage areas for regulated streams--Continued

\begin{tabular}{|c|c|c|c|c|c|c|c|c|c|c|c|c|c|c|c|}
\hline \multirow{3}{*}{$\begin{array}{c}\begin{array}{c}\text { Map } \\
\text { num- } \\
\text { ber }\end{array} \\
7710\end{array}$} & \multirow{3}{*}{$\begin{array}{c}\begin{array}{c}\text { Station } \\
\text { number }\end{array} \\
06771000\end{array}$} & \multirow{3}{*}{$\begin{array}{l}\begin{array}{c}\text { Station name } \\
\text { (station skew_-skew relations } \\
\text { skew }- \text { peak-flow regional equations or remarks) }\end{array} \\
\text { Wood R near Riverdale, Nebr. } \\
(--0.350-\text { C\&SC })\end{array}$} & \multirow{3}{*}{$\begin{array}{c}\begin{array}{c}\text { Gage } \\
\text { type }\end{array} \\
\mathrm{CR}\end{array}$} & \multicolumn{8}{|c|}{$\begin{array}{l}\text { Peak discharge }\left(\mathrm{ft}^{3} / \mathrm{s}\right) \text { for given recurrence interval (years) } \\
\text { and/or remarks }\end{array}$} & \multirow{3}{*}{$\begin{array}{c}\begin{array}{c}\text { Type and length } \\
\text { (years) of analysis } \\
\text { - regional } \\
\text { equation- }\end{array} \\
\text { LP3W } 35 \\
\text { - C\&SC- }\end{array}$} & \multirow{3}{*}{$\begin{array}{c}\begin{array}{c}\text { Period of } \\
\text { peak-flow } \\
\text { record }\end{array} \\
1923 \\
1947-80\end{array}$} & \multirow{2}{*}{\multicolumn{2}{|c|}{$\begin{array}{c}\text { WY and dis- } \\
\text { charge }\left(\mathrm{ft}^{3} / \mathrm{s}\right) \\
\text { of maximum } \\
\text { peak }\end{array}$}} \\
\hline & & & & 2 & 5 & 10 & 25 & 50 & 100 & 200 & 500 & & & & \\
\hline & & & & $\begin{array}{l}505 \\
579\end{array}$ & $\begin{array}{l}1,440 \\
1,340\end{array}$ & $\begin{array}{l}2,460 \\
2,020\end{array}$ & $\begin{array}{l}4,270 \\
3,080\end{array}$ & $\begin{array}{l}6,060 \\
4,010\end{array}$ & $\begin{array}{l}8,270 \\
5,050\end{array}$ & $\begin{array}{r}11,000 \\
6,210\end{array}$ & $\begin{array}{r}15,300 \\
7,900\end{array}$ & & & 1947 & 20,000 \\
\hline 7715 & 06771500 & $\begin{array}{l}\text { Wood R near Gibbon, Nebr. } \\
(-0.214-\text { Skew map }-0.340-C \& S C)\end{array}$ & $\mathrm{CR}$ & $\begin{array}{l}555 \\
476\end{array}$ & $\begin{array}{l}1,340 \\
1,100\end{array}$ & $\begin{array}{l}2,040 \\
1,640\end{array}$ & $\begin{array}{l}3,110 \\
2,480\end{array}$ & $\begin{array}{l}4,020 \\
3,210\end{array}$ & $\begin{array}{l}5,020 \\
4,020\end{array}$ & $\begin{array}{l}6,100 \\
4,900\end{array}$ & $\begin{array}{l}7,650 \\
6,200\end{array}$ & $\begin{array}{l}\text { LP3W } \\
-\mathrm{C} \& \mathrm{SC}-\end{array}$ & 1949-76 & 1967 & 4,050 \\
\hline 7720 & 06772000 & $\begin{array}{l}\text { Wood R near Alda, Nebr. } \\
(-0.537 \text {-Skew map } \quad-0.340-C \& S C)\end{array}$ & CR & $\begin{array}{l}354 \\
589\end{array}$ & $\begin{array}{r}731 \\
1,340\end{array}$ & $\begin{array}{l}1,030 \\
2,000\end{array}$ & $\begin{array}{l}1,460 \\
3,010\end{array}$ & $\begin{array}{l}1,810 \\
3,880\end{array}$ & $\begin{array}{l}2,160 \\
4,850\end{array}$ & $\begin{array}{l}2,540 \\
5,910\end{array}$ & $\begin{array}{l}3,050 \\
7,450\end{array}$ & $\begin{array}{l}\text { LP3W } 40 \\
-\mathrm{C} \& \mathrm{SC}-\end{array}$ & 1954-93 & 1967 & 1,630 \\
\hline 7740 & 06774000 & $\begin{array}{l}\text { Platte R near Duncan, Nebr. } \\
\left(59,300 \mathrm{mi}^{2} \text {, approximately, of which about } 54,600 \mathrm{mi}^{2} \text { con }\right.\end{array}$ & $\begin{array}{l}\text { CR } \\
\text { atributes }\end{array}$ & $\begin{array}{l}7,970 \\
\text { directly to }\end{array}$ & $\begin{array}{l}13,300 \\
\text { surface } \mathrm{rl}\end{array}$ & $\begin{array}{c}17,600 \\
\text { inoff) }\end{array}$ & 24,300 & 30,200 & 36,800 & 44,500 & 56,200 & REG 53 & $\begin{array}{l}\text { 1896-1909, } \\
\text { 1911-15, } \\
1928-93\end{array}$ & 1905 & 44,100 \\
\hline 7755 & 06775500 & $\begin{array}{l}\text { Middle Loup R at Dunning, Nebr. } \\
(-+1.083-\mathrm{HPS})\end{array}$ & $\mathrm{CR}$ & $\begin{array}{l}722 \\
504\end{array}$ & $\begin{array}{l}887 \\
799\end{array}$ & $\begin{array}{r}1,020 \\
971\end{array}$ & $\begin{array}{l}1,200 \\
1,350\end{array}$ & $\begin{array}{l}1,350 \\
1,580\end{array}$ & $\begin{array}{l}1,510 \\
2,000\end{array}$ & $\begin{array}{l}1,700 \\
2,510\end{array}$ & $\begin{array}{l}1,960 \\
3,340\end{array}$ & $\begin{array}{l}\text { LP3W } 48 \\
-\mathrm{HPS}-\end{array}$ & $1946-93$ & 1989 & 2,160 \\
\hline 7759 & 06775900 & $\begin{array}{l}\text { Dismal R near Thedford, Nebr. } \\
(-+1.112-\mathrm{HPS})\end{array}$ & $\mathrm{CR}$ & $\begin{array}{l}318 \\
331\end{array}$ & $\begin{array}{l}447 \\
447\end{array}$ & $\begin{array}{l}559 \\
527\end{array}$ & $\begin{array}{l}736 \\
638\end{array}$ & $\begin{array}{l}897 \\
637\end{array}$ & $\begin{array}{r}1,090 \\
808\end{array}$ & $\begin{array}{l}1,310 \\
1,010\end{array}$ & $\begin{array}{l}1,670 \\
1,350\end{array}$ & $\begin{array}{l}\text { LP3W } 27 \\
-\mathrm{HPS}-\end{array}$ & $1967-93$ & 1983 & 1,160 \\
\hline 7765 & 06776500 & $\begin{array}{l}\text { Dismal } R \text { at Dunning, Nebr. } \\
(+1.619-\mathrm{HP}+1.118-\mathrm{HPS}, \mathrm{HPC})\end{array}$ & CR & $\begin{array}{l}541 \\
456 \\
589\end{array}$ & $\begin{array}{l}680 \\
648 \\
684\end{array}$ & $\begin{array}{l}789 \\
767 \\
832\end{array}$ & $\begin{array}{l}948 \\
929 \\
850\end{array}$ & $\begin{array}{r}1,080 \\
961 \\
1,040\end{array}$ & $\begin{array}{l}1,230 \\
1,210 \\
1,260\end{array}$ & $\begin{array}{l}1,390 \\
1,500 \\
1,520\end{array}$ & $\begin{array}{l}1,640 \\
1,990 \\
1,940\end{array}$ & $\begin{array}{c}\text { LP3W } 49 \\
\text {-HPS- } \\
\text {-HPC- }\end{array}$ & $\begin{array}{l}1932, \\
1946-93\end{array}$ & 1983 & 1,290 \\
\hline 7770 & 06777000 & $\begin{array}{l}\text { Middle Loup R near Milburn, Nebr. } \\
(-\quad+1.021 \text {-New station for HPS network analysis) }\end{array}$ & $\mathrm{CR}$ & $\begin{array}{l}1,450 \\
1,990\end{array}$ & $\begin{array}{l}1,830 \\
3,060\end{array}$ & $\begin{array}{l}2,120 \\
3,390\end{array}$ & $\begin{array}{l}2,530 \\
4,600\end{array}$ & $\begin{array}{l}2,860 \\
5,080\end{array}$ & $\begin{array}{l}3,220 \\
6,350\end{array}$ & $\begin{array}{l}3,620 \\
7,830\end{array}$ & $\begin{array}{r}4,200 \\
10,500\end{array}$ & $\begin{array}{l}\text { LP3W } 9 \\
- \text { HPS- }\end{array}$ & $\begin{array}{l}1952-56 \\
1958 \\
1961-64\end{array}$ & 1952 & 2,440 \\
\hline 7775 & 06777500 & $\begin{array}{l}\text { Middle Loup R at Walworth, Nebr. } \\
(-+1.016-\mathrm{HPS}, \mathrm{HPC})\end{array}$ & $\mathrm{CR}$ & $\begin{array}{l}1,820 \\
2,280 \\
2,220\end{array}$ & $\begin{array}{l}2,240 \\
3,570 \\
3,300\end{array}$ & $\begin{array}{l}2,540 \\
4,040 \\
4,000\end{array}$ & $\begin{array}{l}2,970 \\
5,520 \\
4,660\end{array}$ & $\begin{array}{l}3,320 \\
6,060 \\
5,930\end{array}$ & $\begin{array}{l}3,690 \\
7,630 \\
7,440\end{array}$ & $\begin{array}{l}4,090 \\
9,490 \\
9,260\end{array}$ & $\begin{array}{r}4,660 \\
12,500 \\
12,200\end{array}$ & $\begin{array}{l}\text { LP3W } 20 \\
\text {-HPS- } \\
\text {-HPC- }\end{array}$ & 1941-60 & 1946 & 2,990 \\
\hline 7776 & 06777600 & $\begin{array}{l}\text { Lillian Cr trib near Broken Bow, Nebr. } \\
(+0.044 \text {-Skew map }-0.330-\text { C\&SC })\end{array}$ & PS & $\begin{array}{l}3 \\
6\end{array}$ & $\begin{array}{r}8 \\
20\end{array}$ & $\begin{array}{l}11 \\
33\end{array}$ & $\begin{array}{l}17 \\
56\end{array}$ & $\begin{array}{l}22 \\
76\end{array}$ & $\begin{array}{r}27 \\
101\end{array}$ & $\begin{array}{r}33 \\
129\end{array}$ & $\begin{array}{r}42 \\
173\end{array}$ & $\begin{array}{l}\text { LP3W } \\
-\mathrm{C} \& \mathrm{SC}-\end{array}$ & 1952-78 & $\begin{array}{l}1962, \\
1978\end{array}$ & 20 \\
\hline 7777 & 06777700 & $\begin{array}{l}\text { Lillian Cr near Broken Bow, Nebr. } \\
(-0.568 \text {-Skew map }-0.325 \text {-C\&SC) }\end{array}$ & PS & $\begin{array}{l}78 \\
33\end{array}$ & $\begin{array}{l}335 \\
143\end{array}$ & $\begin{array}{l}675 \\
290\end{array}$ & $\begin{array}{r}1,360 \\
591\end{array}$ & $\begin{array}{r}2,090 \\
918\end{array}$ & $\begin{array}{l}3,020 \\
1,340\end{array}$ & $\begin{array}{l}4,180 \\
1,880\end{array}$ & $\begin{array}{l}6,100 \\
2,790\end{array}$ & $\begin{array}{l}\text { LP3W } \\
-\mathrm{C} \& \mathrm{SC}-\end{array}$ & $\begin{array}{l}\text { 1947, } \\
1951-78\end{array}$ & 1947 & 930 \\
\hline 7778 & 06777800 & $\begin{array}{l}\text { Lillian Cr trib near Walworth, Nebr. } \\
(-0.285 \text {-Skew map } \quad-0.325-\text { C\&SC) }\end{array}$ & PS & $\begin{array}{r}5 \\
27\end{array}$ & $\begin{array}{r}49 \\
125\end{array}$ & $\begin{array}{l}187 \\
260\end{array}$ & $\begin{array}{l}719 \\
545\end{array}$ & $\begin{array}{r}1,630 \\
858\end{array}$ & $\begin{array}{l}3,290 \\
1,270\end{array}$ & $\begin{array}{l}6,110 \\
1,800\end{array}$ & $\begin{array}{r}12,500 \\
2,700\end{array}$ & $\begin{array}{l}\text { LP3W } 28 \\
-\mathrm{C} \& \mathrm{SC}-\end{array}$ & $1951-78$ & 1951 & 585 \\
\hline 7780 & 06778000 & $\begin{array}{l}\text { Middle Loup R at Sargent, Nebr. } \\
(-+1.004-\text { HPS, HPC })\end{array}$ & CR & $\begin{array}{l}1,780 \\
2,440 \\
2,800\end{array}$ & $\begin{array}{l}2,260 \\
3,840 \\
4,220\end{array}$ & $\begin{array}{l}2,630 \\
4,490 \\
5,240\end{array}$ & $\begin{array}{l}3,160 \\
6,170 \\
6,660\end{array}$ & $\begin{array}{l}3,610 \\
6,810 \\
8,570\end{array}$ & $\begin{array}{r}4,090 \\
8,620 \\
10,900\end{array}$ & $\begin{array}{r}4,620 \\
10,800 \\
13,700\end{array}$ & $\begin{array}{r}5,400 \\
14,300 \\
18,400\end{array}$ & $\begin{array}{l}\text { LP3W } 20 \\
\text {-HPS- } \\
\text {-HPC- }\end{array}$ & $\begin{array}{l}\text { 1937-38, } \\
1953-70\end{array}$ & 1962 & 3,200 \\
\hline 7790 & 06779000 & $\begin{array}{l}\text { Middle Loup } R \text { at Arcadia, Nebr. } \\
(+1.032-\mathrm{HP}+0.943-\mathrm{HPS})\end{array}$ & CR & $\begin{array}{l}3,030 \\
3,530\end{array}$ & $\begin{array}{l}4,780 \\
5,760\end{array}$ & $\begin{array}{l}6,380 \\
7,020\end{array}$ & $\begin{array}{l}9,010 \\
9,750\end{array}$ & $\begin{array}{l}11,500 \\
11,000\end{array}$ & $\begin{array}{l}14,600 \\
14,000\end{array}$ & $\begin{array}{l}18,300 \\
17,500\end{array}$ & $\begin{array}{l}24,500 \\
23,200\end{array}$ & $\begin{array}{l}\text { LP3W } 56 \\
-\mathrm{HPS}-\end{array}$ & $1938-93$ & 1947 & 18,500 \\
\hline 7800 & 06780000 & $\begin{array}{l}\text { Middle Loup R at Rockville, Nebr. } \\
(-+0.918-\mathrm{HPS})\end{array}$ & CR & $\begin{array}{l}2,930 \\
4,460\end{array}$ & $\begin{array}{l}4,940 \\
7,330\end{array}$ & $\begin{array}{l}6,870 \\
9,180\end{array}$ & $\begin{array}{l}10,200 \\
13,000\end{array}$ & $\begin{array}{l}13,500 \\
14,800\end{array}$ & $\begin{array}{l}17,600 \\
19,000\end{array}$ & $\begin{array}{l}22,800 \\
23,900\end{array}$ & $\begin{array}{l}31,800 \\
32,000\end{array}$ & $\begin{array}{l}\text { LP3W } 17 \\
-\mathrm{HPS}-\end{array}$ & $\begin{array}{l}1956-64, \\
1968-75\end{array}$ & 1957 & 10,400 \\
\hline 7825 & 06782500 & $\begin{array}{l}\text { S Loup R at Ravenna, Nebr. } \\
(+0.507-\mathrm{HP}+0.458-\mathrm{HPS}\end{array}$ & CR & $\begin{array}{l}3,660 \\
3,780\end{array}$ & $\begin{array}{l}8,220 \\
6,340\end{array}$ & $\begin{array}{l}13,100 \\
12,400\end{array}$ & $\begin{array}{l}22,200 \\
17,500\end{array}$ & $\begin{array}{l}31,700 \\
21,000\end{array}$ & $\begin{array}{l}44,400 \\
28,800\end{array}$ & $\begin{array}{l}61,000 \\
38,700\end{array}$ & $\begin{array}{l}90,700 \\
55,600\end{array}$ & $\begin{array}{l}\text { LP3W } 25 \\
\text {-HPS- }\end{array}$ & $\begin{array}{l}1941-58 \\
1968-75\end{array}$ & 1947 & 41,000 \\
\hline 7826 & 06782600 & $\begin{array}{l}\text { S Br Mud Cr trib near Broken Bow, Nebr. } \\
(-0.715 \text {-Skew map, HP }\end{array}$ & PS & 65 & 131 & 184 & $\begin{array}{l}258 \\
T D A\end{array}$ & $<1 \mathrm{mi}^{32}$ & 379 & 444 & 533 & LP3W 28 & $1951-78$ & 1972 & 218 \\
\hline
\end{tabular}


Table B2. Peak-flow frequency data for streamflow-gaging stations in Nebraska and for selected out-of-state stations,

and drainage areas for regulated streams--Continued

\begin{tabular}{|c|c|c|c|c|c|c|c|c|c|c|c|c|c|c|c|c|}
\hline \multirow{18}{*}{ 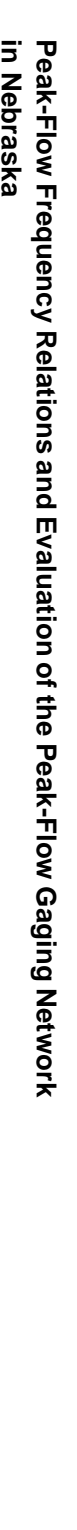 } & \multirow{2}{*}{$\begin{array}{c}\begin{array}{c}\text { Map } \\
\text { num- } \\
\text { ber }\end{array} \\
7827\end{array}$} & \multirow{2}{*}{$\begin{array}{c}\begin{array}{c}\text { Station } \\
\text { number }\end{array} \\
06782700\end{array}$} & \multirow{2}{*}{$\begin{array}{l}\begin{array}{c}\text { Station name } \\
\text { (station skew - skew relations } \\
\text { skew-peak-flow regional equations or remarks) }\end{array} \\
\begin{array}{l}\text { S Br Mud Cr at Broken Bow, Nebr. } \\
(+0.592-\mathrm{HP}+0.420-\mathrm{HPS})\end{array}\end{array}$} & \multirow{2}{*}{$\begin{array}{l}\text { Gage } \\
\text { type }\end{array}$} & \multicolumn{8}{|c|}{$\begin{array}{c}\text { Peak discharge }\left(\mathrm{ftt}^{3} / \mathrm{s}\right) \text { for given recurrence interval (years) } \\
\text { and/or remarks }\end{array}$} & \multirow{2}{*}{$\begin{array}{c}\begin{array}{c}\text { Type and length } \\
\text { (years) of analysis } \\
\text {-regional } \\
\text { equation- }\end{array} \\
\begin{array}{c}\text { LP3W } 30 \\
\text {-HPS- }\end{array}\end{array}$} & \multirow{2}{*}{$\begin{array}{c}\begin{array}{c}\text { Period of } \\
\text { peak-flow } \\
\text { record }\end{array} \\
1951-77\end{array}$} & \multicolumn{2}{|c|}{$\begin{array}{c}\text { WY and dis- } \\
\text { charge }\left(\mathrm{ft}^{3} / \mathrm{s}\right) \\
\text { of maximum } \\
\text { peak }\end{array}$} \\
\hline & & & & & $\begin{array}{l}23 \\
83\end{array}$ & $\begin{array}{l}106 \\
144\end{array}$ & $\begin{array}{l}256 \\
378\end{array}$ & $\begin{array}{r}696 \\
1,110\end{array}$ & $\begin{array}{l}1,370 \\
2,130\end{array}$ & $\begin{array}{l}2,590 \\
3,420\end{array}$ & $\begin{array}{l}4,710 \\
5,270\end{array}$ & $\begin{array}{l}9,970 \\
8,970\end{array}$ & & & 1956 & 1,790 \\
\hline & 7828 & 06782800 & $\begin{array}{l}\text { N Br Mud Cr at Broken Bow, Nebr. } \\
(--0.330-\mathrm{C} \& \mathrm{SC})\end{array}$ & PS & $\begin{array}{l}70 \\
58\end{array}$ & $\begin{array}{l}386 \\
220\end{array}$ & $\begin{array}{l}874 \\
417\end{array}$ & $\begin{array}{r}1,980 \\
796\end{array}$ & $\begin{array}{l}3,260 \\
1,190\end{array}$ & $\begin{array}{l}5,000 \\
1,680\end{array}$ & $\begin{array}{l}7,290 \\
2,280\end{array}$ & $\begin{array}{r}11,300 \\
3,260\end{array}$ & $\begin{array}{l}\mathrm{LP} 3 \mathrm{~W} \\
-\mathrm{C} \& \mathrm{SC}-\end{array}$ & $1951-67$ & 1956 & 1,550 \\
\hline & 7829 & 06782900 & $\begin{array}{l}\text { Mud Cr trib near Broken Bow, Nebr. } \\
(+0.148-\text { Skew map }-0.340-\text { C\&SC })\end{array}$ & PS & $\begin{array}{r}30 \\
103\end{array}$ & $\begin{array}{l}184 \\
455\end{array}$ & $\begin{array}{l}441 \\
950\end{array}$ & $\begin{array}{l}1,070 \\
2,010\end{array}$ & $\begin{array}{l}1,850 \\
3,190\end{array}$ & $\begin{array}{l}2,970 \\
4,750\end{array}$ & $\begin{array}{l}4,520 \\
6,760\end{array}$ & $\begin{array}{r}7,410 \\
10,200\end{array}$ & $\begin{array}{l}\mathrm{LP} 3 \mathrm{~W} \\
-\mathrm{C} \& \mathrm{SC}-\end{array}$ & $\begin{array}{l}\text { 1945, } \\
1951-78\end{array}$ & 1945 & 1,500 \\
\hline & 7835 & 06783500 & $\begin{array}{l}\text { Mud Cr near Sweetwater, Nebr. } \\
(--0.350-\text { C\&SC })\end{array}$ & CR & $\begin{array}{r}866 \\
1,690\end{array}$ & $\begin{array}{l}1,910 \\
3,840\end{array}$ & $\begin{array}{l}2,870 \\
5,860\end{array}$ & $\begin{array}{l}4,420 \\
9,070\end{array}$ & $\begin{array}{r}5,830 \\
11,900\end{array}$ & $\begin{array}{r}7,480 \\
15,100\end{array}$ & $\begin{array}{r}9,380 \\
18,700\end{array}$ & $\begin{array}{l}12,300 \\
24,000\end{array}$ & $\begin{array}{l}\mathrm{LP} 3 \mathrm{~W} \\
-\mathrm{C} \& \mathrm{SC}-\end{array}$ & 1947-93 & 1947 & 27,000 \\
\hline & 7840 & 06784000 & $\begin{array}{l}\text { S Loup R at St. Michael, Nebr. } \\
(+0.456-\mathrm{HP}+0.266-\mathrm{HPS})\end{array}$ & $\mathrm{CR}$ & $\begin{array}{l}3,100 \\
6,350\end{array}$ & $\begin{array}{r}7,070 \\
10,800\end{array}$ & $\begin{array}{l}11,200 \\
21,700\end{array}$ & $\begin{array}{l}18,700 \\
32,300\end{array}$ & $\begin{array}{l}26,400 \\
39,300\end{array}$ & $\begin{array}{l}36,300 \\
54,900\end{array}$ & $\begin{array}{l}48,900 \\
74,600\end{array}$ & $\begin{array}{r}70,900 \\
109,000\end{array}$ & $\begin{array}{l}\text { LP3W } 50 \\
-\mathrm{HPS}-\end{array}$ & 1944-93 & 1947 & 50,000 \\
\hline & 7847 & 06784700 & 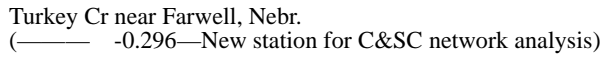 & PS & $\begin{array}{l}356 \\
208\end{array}$ & $\begin{array}{l}967 \\
608\end{array}$ & $\begin{array}{l}1,570 \\
1,020\end{array}$ & $\begin{array}{l}2,550 \\
1,730\end{array}$ & $\begin{array}{l}3,440 \\
2,430\end{array}$ & $\begin{array}{l}4,450 \\
3,240\end{array}$ & $\begin{array}{l}5,590 \\
4,140\end{array}$ & $\begin{array}{l}7,290 \\
5,590\end{array}$ & $\begin{array}{l}\mathrm{LP} 3 \mathrm{~W} \\
-\mathrm{C} \& \mathrm{SC}-\end{array}$ & $1953-78$ & 1965 & 1,450 \\
\hline & 7848 & 06784800 & $\begin{array}{l}\text { Turkey Cr near Dannebrog, Nebr. } \\
(-0.183 \text {-Skew map, NE }-0.273 \text { C\&SC) }\end{array}$ & CR & $\begin{array}{l}759 \\
437\end{array}$ & $\begin{array}{l}1,390 \\
1,170\end{array}$ & $\begin{array}{c}\text { ars to re } \\
1,870 \\
1,920\end{array}$ & $\begin{array}{r}\text { quire com } \\
2,520 \\
3,160\end{array}$ & $\begin{array}{c}\text { osite freq } \\
3,030 \\
4,320\end{array}$ & $\begin{array}{l}3,560 \\
5,660\end{array}$ & $\begin{array}{l}4,110 \\
7,210\end{array}$ & $\begin{array}{l}4,860 \\
9,570\end{array}$ & $\begin{array}{l}\text { LP3W } 19 \\
-\mathrm{C} \& \mathrm{SC}-\end{array}$ & $\begin{array}{l}\text { 1967-70, } \\
\text { 1979-93 }\end{array}$ & 1967 & 2,680 \\
\hline & 7850 & 06785000 & $\begin{array}{l}\text { Middle Loup R at St. Paul, Nebr. } \\
(+0.632-\mathrm{HP}+0.684-\mathrm{HPS})\end{array}$ & $\mathrm{CR}$ & $\begin{array}{r}8,350 \\
10,400\end{array}$ & $\begin{array}{l}14,500 \\
17,600\end{array}$ & $\begin{array}{l}20,100 \\
25,600\end{array}$ & $\begin{array}{l}29,400 \\
34,000\end{array}$ & $\begin{array}{l}38,300 \\
38,500\end{array}$ & $\begin{array}{l}49,200 \\
49,800\end{array}$ & $\begin{array}{l}62,500 \\
63,100\end{array}$ & $\begin{array}{l}84,600 \\
86,300\end{array}$ & $\begin{array}{c}\text { LP3W } 71 \\
-\mathrm{HPS}-\end{array}$ & $\begin{array}{l}\text { 1895-99, } \\
1903 \\
1929-93\end{array}$ & 1947 & 72,000 \\
\hline & 7860 & 06786000 & $\begin{array}{l}\text { N Loup R at Taylor, Nebr. } \\
(+0.615-\mathrm{HP}+1.047-\mathrm{HPS}, \mathrm{HPC})\end{array}$ & $\mathrm{CR}$ & $\begin{array}{r}1,420 \\
856 \\
984\end{array}$ & $\begin{array}{l}1,890 \\
1,510 \\
1,610\end{array}$ & $\begin{array}{l}2,260 \\
1,860 \\
1,950\end{array}$ & $\begin{array}{l}2,810 \\
2,620 \\
2,770\end{array}$ & $\begin{array}{l}3,270 \\
3,300 \\
3,420\end{array}$ & $\begin{array}{l}3,780 \\
4,110 \\
4,200\end{array}$ & $\begin{array}{l}4,350 \\
5,080 \\
5,130\end{array}$ & $\begin{array}{l}5,210 \\
6,660 \\
6,620\end{array}$ & $\begin{array}{l}\text { LP3W } 57 \\
\text { - } 5 \text { HPS- } \\
\text {-HPC- }\end{array}$ & 1937-93 & 1983 & 3,210 \\
\hline & 7870 & 06787000 & $\begin{array}{l}\text { Calamus R near Harrop, Nebr. } \\
(-+1.020-\text { HPS })\end{array}$ & CR & $\begin{array}{l}476 \\
354\end{array}$ & $\begin{array}{l}601 \\
662\end{array}$ & $\begin{array}{l}694 \\
855\end{array}$ & $\begin{array}{r}823 \\
1,320\end{array}$ & $\begin{array}{r}929 \\
1,870\end{array}$ & $\begin{array}{l}1,040 \\
2,340\end{array}$ & $\begin{array}{l}1,170 \\
2,910\end{array}$ & $\begin{array}{l}1,350 \\
3,850\end{array}$ & $\begin{array}{l}\text { LP3W } \\
-\mathrm{HPS}-\end{array}$ & $1978-93$ & 1983 & 801 \\
\hline & 7875 & 06787500 & $\begin{array}{l}\text { Calamus R near Burwell, Nebr. } \\
(+1.223-\mathrm{HP}+1.028-\mathrm{HPS}, \mathrm{HPC})\end{array}$ & CR & $\begin{array}{l}597 \\
501 \\
457\end{array}$ & $\begin{array}{l}810 \\
920 \\
751\end{array}$ & $\begin{array}{r}985 \\
1,160 \\
917\end{array}$ & $\begin{array}{l}1,250 \\
1,600 \\
1,120\end{array}$ & $\begin{array}{l}1,480 \\
2,120 \\
1,340\end{array}$ & $\begin{array}{l}1,750 \\
2,620 \\
1,600\end{array}$ & $\begin{array}{l}2,050 \\
3,200 \\
1,900\end{array}$ & $\begin{array}{l}2,520 \\
4,160 \\
2,370\end{array}$ & $\begin{array}{l}\text { LP3W } 53 \\
\text {-HPS- } \\
\text {-HPC- }\end{array}$ & 1941-93 & 1964 & 1,790 \\
\hline & 7885 & 06788500 & $\begin{array}{l}\text { N Loup R at Ord, Nebr. } \\
(+0.720-\mathrm{HP} \quad+0.938-\mathrm{HPS}, \mathrm{HPC})\end{array}$ & CR & $\begin{array}{l}2,750 \\
2,400 \\
2,910\end{array}$ & $\begin{array}{l}4,210 \\
4,400 \\
5,370\end{array}$ & $\begin{array}{l}5,470 \\
5,600 \\
6,930\end{array}$ & $\begin{array}{r}7,480 \\
8,100 \\
10,900\end{array}$ & $\begin{array}{r}9,330 \\
10,400 \\
14,100\end{array}$ & $\begin{array}{l}11,500 \\
13,100 \\
18,000\end{array}$ & $\begin{array}{l}14,100 \\
16,300 \\
22,800\end{array}$ & $\begin{array}{l}18,400 \\
21,400 \\
30,700\end{array}$ & $\begin{array}{l}\text { LP3W } 44 \\
\text { - HPS- } \\
\text {-HPC- }\end{array}$ & $\begin{array}{l}1936-38 \\
1952-93\end{array}$ & 1962 & 10,100 \\
\hline & 7889a & 06788988 & $\begin{array}{l}\text { Mira Cr near North Loup, Nebr. } \\
(-\quad-0.324-\text { New station for C\&SC network analysis) }\end{array}$ & CR & $\begin{array}{l}306 \\
981\end{array}$ & $\begin{array}{l}1,250 \\
2,700\end{array}$ & $\begin{array}{l}2,480 \\
4,490\end{array}$ & $\begin{array}{l}5,010 \\
7,710\end{array}$ & $\begin{array}{r}7,750 \\
10,900\end{array}$ & $\begin{array}{l}11,300 \\
14,500\end{array}$ & $\begin{array}{l}15,900 \\
18,600\end{array}$ & $\begin{array}{l}23,700 \\
25,200\end{array}$ & $\begin{array}{l}\mathrm{LP} 3 \mathrm{~W} \\
-\mathrm{C} \& \mathrm{SC}-\end{array}$ & $1980-93$ & 1981 & 3,460 \\
\hline & 7890 & 06789000 & $\begin{array}{l}\text { N Loup R at Scotia, Nebr. } \\
(+0.997-\mathrm{HP}+0.898-\mathrm{HPS}, \mathrm{HPC})\end{array}$ & CR & $\begin{array}{l}5,250 \\
3,120 \\
3,860\end{array}$ & $\begin{array}{r}10,200 \\
5,640 \\
7,070\end{array}$ & $\begin{array}{r}15,500 \\
7,390 \\
9,620\end{array}$ & $\begin{array}{l}25,400 \\
11,100 \\
15,400\end{array}$ & $\begin{array}{l}36,000 \\
14,000 \\
20,300\end{array}$ & $\begin{array}{l}50,300 \\
17,900 \\
26,500\end{array}$ & $\begin{array}{l}69,500 \\
22,500 \\
34,200\end{array}$ & $\begin{array}{l}105,000 \\
30,000 \\
47,200\end{array}$ & $\begin{array}{c}\text { LP3W } 33 \\
\text {-HPS- } \\
\text {-HPC- }\end{array}$ & $1937-69$ & 1966 & 37,600 \\
\hline & 7891 & 06789100 & $\begin{array}{l}\text { Davis Cr trib near North Loup, Nebr. } \\
(-0.336-\text { C\&SC })\end{array}$ & PS & $\begin{array}{r}220 \\
84\end{array}$ & $\begin{array}{l}740 \\
350\end{array}$ & $\begin{array}{r}1,320 \\
707\end{array}$ & $\begin{array}{l}2,370 \\
1,450\end{array}$ & $\begin{array}{l}3,390 \\
2,260\end{array}$ & $\begin{array}{l}4,610 \\
3,310\end{array}$ & $\begin{array}{l}6,030 \\
4,660\end{array}$ & $\begin{array}{l}8,250 \\
6,940\end{array}$ & $\begin{array}{l}\mathrm{LP} 3 \mathrm{~W} \\
-\mathrm{C} \& \mathrm{SC}-\end{array}$ & $1951-67$ & 1962 & 1,780 \\
\hline & 7892 & 06789200 & $\begin{array}{l}\text { Davis Cr trib \#2 near North Loup, Nebr. } \\
(-0.210 \text {-Skew map, NE }+0.318-C \& S C)\end{array}$ & PS & $\begin{array}{l}119 \\
117\end{array}$ & $\begin{array}{l}471 \\
449\end{array}$ & $\begin{array}{l}922 \\
869\end{array}$ & $\begin{array}{l}1,820 \\
1,710\end{array}$ & $\begin{array}{l}2,770 \\
2,590\end{array}$ & $\begin{array}{l}4,000 \\
3,710\end{array}$ & $\begin{array}{l}5,540 \\
5,110\end{array}$ & $\begin{array}{l}8,100 \\
7,430\end{array}$ & $\begin{array}{l}\mathrm{LP} 3 \mathrm{~W} \\
-\mathrm{C} \& \mathrm{SC}-\end{array}$ & 1951-70 & 1966 & 2,360 \\
\hline & 7893 & 06789300 & $\begin{array}{l}\text { Davis Cr near North Loup, Nebr. } \\
\left(\begin{array}{r}-0.364-\text { C\&SC })\end{array}\right.\end{array}$ & PS & $\begin{array}{l}684 \\
245\end{array}$ & $\begin{array}{r}1,160 \\
764\end{array}$ & $\begin{array}{l}1,490 \\
1,340\end{array}$ & $\begin{array}{l}1,920 \\
2,390\end{array}$ & $\begin{array}{l}2,230 \\
3,420\end{array}$ & $\begin{array}{l}2,540 \\
4,680\end{array}$ & $\begin{array}{l}2,850 \\
6,170\end{array}$ & $\begin{array}{l}3,260 \\
8,540\end{array}$ & $\begin{array}{l}\mathrm{LP} 3 \mathrm{~W} \\
-\mathrm{C} \& \mathrm{SC}-\end{array}$ & $1951-67$ & 1957 & 1,820 \\
\hline
\end{tabular}


Table B2. Peak-flow frequency data for streamflow-gaging stations in Nebraska and for selected out-of-state stations,

and drainage areas for regulated streams--Continued

\begin{tabular}{|c|c|c|c|c|c|c|c|c|c|c|c|c|c|c|c|}
\hline \multirow{3}{*}{$\begin{array}{c}\begin{array}{c}\text { Map } \\
\text { num- } \\
\text { ber }\end{array} \\
7894\end{array}$} & \multirow{3}{*}{$\begin{array}{c}\begin{array}{c}\text { Station } \\
\text { number }\end{array} \\
06789400\end{array}$} & \multirow{3}{*}{$\begin{array}{c}\begin{array}{c}\text { Station name } \\
\text { (station skew } \\
\text { skew relations }\end{array} \text { generalized } \\
\text { skew-peak-flow regional equations or remarks) }\end{array}$} & \multirow{3}{*}{$\begin{array}{c}\begin{array}{c}\text { Gage } \\
\text { type }\end{array} \\
\text { PS }\end{array}$} & \multicolumn{8}{|c|}{$\begin{array}{l}\left.\text { Peak discharge ( } \mathrm{ft}^{3} / \mathrm{s}\right) \text { for given recurrence interval (years) } \\
\text { and/or remarks }\end{array}$} & \multirow{3}{*}{$\begin{array}{c}\begin{array}{c}\text { Type and length } \\
\text { (years) of analysis } \\
\text {-regional } \\
\text { equation- }\end{array} \\
\text { LP3W } 28 \\
\text {-C\&SC- }\end{array}$} & \multirow{3}{*}{$\begin{array}{c}\begin{array}{c}\text { Period of } \\
\text { peak-flow } \\
\text { record }\end{array} \\
1951-78\end{array}$} & \multirow{2}{*}{\multicolumn{2}{|c|}{$\begin{array}{c}\text { WY and dis- } \\
\text { charge }\left(\mathrm{ft}^{3} / \mathrm{s}\right) \\
\text { of maximum } \\
\text { peak }\end{array}$}} \\
\hline & & & & 2 & 5 & 10 & 25 & 50 & 100 & 200 & 500 & & & & \\
\hline & & & & $\begin{array}{l}218 \\
325\end{array}$ & $\begin{array}{l}823 \\
993\end{array}$ & $\begin{array}{l}1,550 \\
1,730\end{array}$ & $\begin{array}{l}2,930 \\
3,070\end{array}$ & $\begin{array}{l}4,310 \\
4,380\end{array}$ & $\begin{array}{l}6,010 \\
5,970\end{array}$ & $\begin{array}{l}8,050 \\
7,860\end{array}$ & $\begin{array}{l}11,300 \\
10,800\end{array}$ & & & 1957 & 2,220 \\
\hline 7895 & 06789500 & 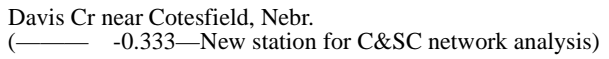 & CR & 738 & $\begin{array}{l}1,200 \\
\text { Basin }\end{array}$ & $\begin{array}{l}1,530 \\
\text { character }\end{array}$ & $\begin{array}{l}1,940 \\
\text { stic(s) out }\end{array}$ & $\begin{array}{l}2,250 \\
\text { side of ran }\end{array}$ & $\begin{array}{l}2,560 \\
\text { ige for equ }\end{array}$ & $\begin{array}{l}2,860 \\
\text { lations }\end{array}$ & 3,270 & $\begin{array}{l}\mathrm{LP} 3 \mathrm{~W} \\
-\mathrm{C} \& \mathrm{SC}-\end{array}$ & $1948-58$ & 1958 & 1,720 \\
\hline 7905 & 06790500 & $\begin{array}{l}\text { N Loup R near St. Paul, Nebr. } \\
(+1.196-\text { HP }+0.849-\text { HPS, HPC })\end{array}$ & CR & $\begin{array}{l}5,630 \\
4,200 \\
5,360\end{array}$ & $\begin{array}{r}10,800 \\
7,500 \\
9,820\end{array}$ & $\begin{array}{l}16,300 \\
10,300 \\
14,400\end{array}$ & $\begin{array}{l}26,600 \\
15,100 \\
21,900\end{array}$ & $\begin{array}{l}37,500 \\
18,700 \\
29,600\end{array}$ & $\begin{array}{l}52,300 \\
24,000 \\
39,400\end{array}$ & $\begin{array}{l}72,000 \\
30,000 \\
51,700\end{array}$ & $\begin{array}{c}108,000 \\
40,600 \\
72,800\end{array}$ & $\begin{array}{c}\text { LP3W } 69 \\
\text {-HPS- } \\
\text {-HPC- }\end{array}$ & $\begin{array}{l}\text { 1896-97, } \\
1899,1903 \\
1929-93\end{array}$ & 1896 & 90,000 \\
\hline 7906 & 06790600 & $\begin{array}{l}\text { East Br Spring Cr trib near Wolbach, Nebr. } \\
(+0.122 \text {-Skew map, NE }-0.238-N E, C \& S C)\end{array}$ & PS & $\begin{array}{r}68 \\
154 \\
29\end{array}$ & $\begin{array}{l}283 \\
387 \\
118\end{array}$ & $\begin{array}{l}570 \\
628 \\
231\end{array}$ & $\begin{array}{r}1,160 \\
1,060 \\
455\end{array}$ & $\begin{array}{r}1,810 \\
1,480 \\
691\end{array}$ & $\begin{array}{r}2,660 \\
1,990 \\
994\end{array}$ & $\begin{array}{l}3,750 \\
2,730 \\
1,370\end{array}$ & $\begin{array}{l}5,600 \\
3,700 \\
1,990\end{array}$ & $\begin{array}{c}\mathrm{LP} 3 \mathrm{~W} \quad 27 \\
-\mathrm{NE}- \\
-\mathrm{C} \& \mathrm{SC}-\end{array}$ & 1952-78 & 1966 & 1,340 \\
\hline 7907 & 06790700 & $\begin{array}{l}\text { W Br Spring Cr at Brayton, Nebr. } \\
(-0.260-\mathrm{NE}, \mathrm{C} \& \mathrm{SC})\end{array}$ & PS & $\begin{array}{l}527 \\
734 \\
265\end{array}$ & $\begin{array}{r}1,610 \\
1,710 \\
855\end{array}$ & $\begin{array}{l}2,800 \\
2,620 \\
1,530\end{array}$ & $\begin{array}{l}4,940 \\
4,140 \\
2,770\end{array}$ & $\begin{array}{l}7,040 \\
5,530 \\
3,990\end{array}$ & $\begin{array}{l}9,600 \\
7,170 \\
5,490\end{array}$ & $\begin{array}{r}12,700 \\
8,980 \\
7,280\end{array}$ & $\begin{array}{l}17,600 \\
11,900 \\
10,100\end{array}$ & $\begin{array}{c}\mathrm{LP} 3 \mathrm{~W} \quad 27 \\
-\mathrm{NE}- \\
-\mathrm{C} \& \mathrm{SC}-\end{array}$ & $1952-78$ & 1966 & 12,800 \\
\hline 7908 & 06790800 & $\begin{array}{l}\text { W Br Spring Cr near Wolbach, Nebr. } \\
(--0.258-\mathrm{NE}, \mathrm{C} \& \mathrm{SC})\end{array}$ & PS & $\begin{array}{r}1,050 \\
1,190 \\
469\end{array}$ & $\begin{array}{l}2,600 \\
2,770 \\
1,360\end{array}$ & $\begin{array}{l}4,100 \\
4,240 \\
2,310\end{array}$ & $\begin{array}{l}6,540 \\
6,640 \\
3,990\end{array}$ & $\begin{array}{l}8,770 \\
8,840 \\
5,590\end{array}$ & $\begin{array}{r}11,400 \\
11,400 \\
7,520\end{array}$ & $\begin{array}{r}14,300 \\
14,300 \\
9,770\end{array}$ & $\begin{array}{l}18,800 \\
18,800 \\
13,300\end{array}$ & $\begin{array}{c}\mathrm{LP} 3 \mathrm{~W} \\
-\mathrm{NE}- \\
-\mathrm{C} \& \mathrm{SC}-\end{array}$ & $1951-67$ & 1966 & 12,800 \\
\hline 7909 & 06790900 & $\begin{array}{l}\text { Mary's Cr at Wolbach, Nebr. } \\
(--0.302-\mathrm{NE}, \mathrm{C} \& \mathrm{SC})\end{array}$ & PS & $\begin{array}{l}172 \\
499 \\
258\end{array}$ & $\begin{array}{r}680 \\
1,260 \\
932\end{array}$ & $\begin{array}{l}1,340 \\
2,040 \\
1,770\end{array}$ & $\begin{array}{l}2,690 \\
3,390 \\
3,430\end{array}$ & $\begin{array}{l}4,160 \\
4,690 \\
5,150\end{array}$ & $\begin{array}{l}6,090 \\
6,260 \\
7,340\end{array}$ & $\begin{array}{r}8,560 \\
8,530 \\
10,000\end{array}$ & $\begin{array}{l}12,800 \\
11,300 \\
14,500\end{array}$ & $\begin{array}{c}\mathrm{LP} 3 \mathrm{~W} \quad 16 \\
-\mathrm{NE}- \\
-\mathrm{C} \& \mathrm{SC}-\end{array}$ & $1952-67$ & 1966 & 4,700 \\
\hline 7911 & 06791100 & $\begin{array}{l}\text { Spring Cr near Cushing, Nebr. } \\
(-0.226-\mathrm{NE}, \mathrm{C} \& \mathrm{SC})\end{array}$ & PS & $\begin{array}{r}887 \\
1,580 \\
1,430\end{array}$ & $\begin{array}{l}2,710 \\
3,680 \\
3,540\end{array}$ & $\begin{array}{l}4,750 \\
5,740 \\
5,640\end{array}$ & $\begin{array}{l}8,530 \\
9,270 \\
9,140\end{array}$ & $\begin{array}{l}12,300 \\
12,700 \\
12,300\end{array}$ & $\begin{array}{l}17,100 \\
16,800 \\
16,000\end{array}$ & $\begin{array}{l}23,000 \\
23,800 \\
20,200\end{array}$ & $\begin{array}{l}32,700 \\
31,000 \\
26,600\end{array}$ & $\begin{array}{c}\mathrm{LP} 3 \mathrm{~W} \\
-\mathrm{NE}- \\
-\mathrm{C} \& \mathrm{SC}-\end{array}$ & $1948-78$ & 1966 & 35,000 \\
\hline 7915 & 06791500 & $\begin{array}{l}\text { Cedar R near Spalding, Nebr. } \\
(+0.924-\mathrm{HP}+1.016-\mathrm{HPS}, \mathrm{HPC}, \mathrm{NE})\end{array}$ & $\mathrm{CR}$ & $\begin{array}{l}620 \\
270 \\
531 \\
937\end{array}$ & $\begin{array}{r}1,090 \\
498 \\
848 \\
1,900\end{array}$ & $\begin{array}{r}1,550 \\
671 \\
1,010 \\
2,810\end{array}$ & $\begin{array}{r}2,370 \\
886 \\
1,720 \\
4,400\end{array}$ & $\begin{array}{l}3,210 \\
1,180 \\
2,050 \\
5,970\end{array}$ & $\begin{array}{l}4,300 \\
1,460 \\
2,450 \\
7,940\end{array}$ & $\begin{array}{r}5,700 \\
1,790 \\
2,920 \\
11,700\end{array}$ & $\begin{array}{r}8,200 \\
2,320 \\
3,690 \\
15,400\end{array}$ & $\begin{array}{l}\text { LP3W } 45 \\
\text {-HPS- } \\
\text {-HPC- } \\
\text {-NE- }\end{array}$ & $\begin{array}{l}1945-53 \\
1958-93\end{array}$ & 1947 & 4,000 \\
\hline 7920 & 06792000 & $\begin{array}{l}\text { Cedar R near Fullerton, Nebr. } \\
(\longleftarrow+0.664-\text { HPS, NE })\end{array}$ & $\mathrm{CR}$ & $\begin{array}{l}2,710 \\
1,890 \\
2,110\end{array}$ & $\begin{array}{l}5,880 \\
3,500 \\
4,560\end{array}$ & $\begin{array}{l}9,310 \\
5,770 \\
6,940\end{array}$ & $\begin{array}{r}15,900 \\
8,500 \\
11,000\end{array}$ & $\begin{array}{l}23,000 \\
11,300 \\
15,000\end{array}$ & $\begin{array}{l}32,600 \\
14,800 \\
19,900\end{array}$ & $\begin{array}{l}45,500 \\
19,200 \\
29,300\end{array}$ & $\begin{array}{l}69,500 \\
26,400 \\
38,100\end{array}$ & $\begin{array}{c}\text { LP3W } 54 \\
\text { - HPS- }- \\
-\mathrm{NE}-\end{array}$ & $\begin{array}{l}1932, \\
1941-93\end{array}$ & 1966 & 64,700 \\
\hline 7930 & 06793000 & $\begin{array}{l}\text { Loup R near Genoa, Nebr. } \\
\left(14,320 \mathrm{mi}^{2} \text {, approximately, of which about } 5,620 \mathrm{mi}^{2}\right. \\
\text { contributes directly to surface runoff) }\end{array}$ & CR & $\begin{array}{l}14,000 \\
\text { Based on } \\
\text { stations }\end{array}$ & $\begin{array}{l}26,700 \\
\text { comparati } \\
\text { below Lo } \\
\text { although c }\end{array}$ & $\begin{array}{l}39,400 \\
\text { ve analysi } \\
\text { up R Pow } \\
\text { oded as st }\end{array}$ & $\begin{array}{l}62,300 \\
\text { of unregu } \\
\text { r Canal, p } \\
\text { ch from } 1\end{array}$ & $\begin{array}{l}85,700 \\
\text { lated and } \\
\text { eak flows } \\
937 \text {. No }\end{array}$ & $\begin{array}{l}116,000 \\
\text { regulated } \\
\text { are not cor } \\
\text { basin cha }\end{array}$ & $\begin{array}{l}155,000 \\
\text { periods of } \\
\text { nsidered re } \\
\text { racteristics }\end{array}$ & $\begin{array}{l}225,000 \\
\text { record for } \\
\text { egulated, }\end{array}$ & LP3S 54 & $\begin{array}{l}1929-32 \\
1944-93\end{array}$ & 1966 & 129,000 \\
\hline 7935 & 06793500 & $\begin{array}{l}\text { Beaver Cr at Loretto, Nebr. } \\
(\longleftarrow+0.677-\mathrm{HPS}, \mathrm{NE})\end{array}$ & CR & $\begin{array}{l}946 \\
591 \\
666\end{array}$ & $\begin{array}{l}1,980 \\
1,260 \\
1,570\end{array}$ & $\begin{array}{l}3,050 \\
1,890 \\
2,540\end{array}$ & $\begin{array}{l}5,010 \\
2,870 \\
4,300\end{array}$ & $\begin{array}{l}7,040 \\
4,390 \\
6,070\end{array}$ & $\begin{array}{l}9,710 \\
5,520 \\
8,270\end{array}$ & $\begin{array}{r}13,200 \\
6,860 \\
12,600\end{array}$ & $\begin{array}{r}19,400 \\
9,050 \\
16,700\end{array}$ & $\begin{array}{l}\mathrm{LP} 3 \mathrm{~W} \\
-\mathrm{HPS}- \\
-\mathrm{NE}-\end{array}$ & $\begin{array}{l}1945-53 \\
1980-93\end{array}$ & 1993 & 5,600 \\
\hline 7939a & 06793995 & $\begin{array}{l}\text { Skeedee } \mathrm{Cr} \text { trib near Genoa, Nebr. } \\
(-)\end{array}$ & PS & 137 & 238 & 316 & $\begin{array}{l}426 \\
T D A\end{array}$ & $1 \mathrm{mi}^{5}$ & 612 & 715 & 863 & LP3W 11 & 1968-78 & 1969 & 485 \\
\hline 7940 & 06794000 & $\begin{array}{l}\text { Beaver Cr at Genoa, Nebr. } \\
(+0.458-\mathrm{HP}+0.450-\mathrm{HPS}, \mathrm{HPC}, \mathrm{NE})\end{array}$ & CR & $\begin{array}{l}2,240 \\
1,850 \\
2,050 \\
1,830\end{array}$ & $\begin{array}{l}4,800 \\
3,420 \\
3,600 \\
4,090\end{array}$ & $\begin{array}{l}7,410 \\
6,410 \\
7,900 \\
6,330\end{array}$ & $\begin{array}{r}12,100 \\
9,520 \\
10,100 \\
10,200\end{array}$ & $\begin{array}{l}17,000 \\
12,900 \\
14,700 \\
13,900\end{array}$ & $\begin{array}{l}23,200 \\
17,300 \\
20,700 \\
18,400\end{array}$ & $\begin{array}{l}31,200 \\
22,800 \\
28,600 \\
26,600\end{array}$ & $\begin{array}{l}45,300 \\
32,100 \\
42,800 \\
34,700\end{array}$ & $\begin{array}{l}\text { LP3W } 53 \\
\text {-HPS- } \\
\text {-HPC- } \\
\text { - } \mathrm{NE}-\end{array}$ & 1941-93 & 1950 & 21,200 \\
\hline
\end{tabular}


Table B2. Peak-flow frequency data for streamflow-gaging stations in Nebraska and for selected out-of-state stations,

and drainage areas for regulated streams--Continued

\begin{tabular}{|c|c|c|c|c|c|c|c|c|c|c|c|c|c|c|c|c|}
\hline \multirow{17}{*}{ 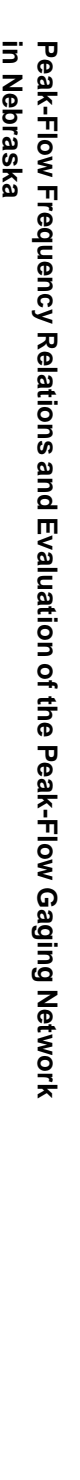 } & \multirow{3}{*}{$\begin{array}{c}\begin{array}{c}\text { Map } \\
\text { num- } \\
\text { ber }\end{array} \\
7945\end{array}$} & \multirow{3}{*}{$\begin{array}{c}\begin{array}{c}\text { Station } \\
\text { number }\end{array} \\
06794500\end{array}$} & \multirow{3}{*}{$\begin{array}{l}\begin{array}{c}\text { Station name } \\
\text { (station skew-skew relations }\end{array} \\
\text { generalized } \\
\text { skew-peak-flow regional equations or remarks) } \\
\text { Loup } \mathrm{R} \text { at Columbus, Nebr. } \\
\left(15,200 \mathrm{mi}^{2}, \text { approximately, of which about } 6,230 \mathrm{mi}^{2}\right. \\
\text { contributes directly to surface runoff }) \\
(+0.202-\mathrm{HP}+0.645-\mathrm{HPS})\end{array}$} & \multirow{3}{*}{$\begin{array}{c}\begin{array}{c}\text { Gage } \\
\text { type }\end{array} \\
\mathrm{CR}\end{array}$} & \multicolumn{8}{|c|}{$\begin{array}{l}\text { Peak discharge }\left(\mathrm{ft}^{3} / \mathrm{s}\right) \text { for given recurrence interval (years) } \\
\text { and/or remarks }\end{array}$} & \multirow{2}{*}{$\begin{array}{c}\begin{array}{c}\text { Type and length } \\
\text { (years) of analysis } \\
\text {-regional } \\
\text { equation- }\end{array} \\
\text { LP3W } 67 \\
\text { - HPS_- }\end{array}$} & \multirow{2}{*}{$\begin{array}{c}\begin{array}{c}\text { Period of } \\
\text { peak-flow } \\
\text { record }\end{array} \\
1895-1915 \\
1933-78\end{array}$} & \multicolumn{2}{|c|}{$\begin{array}{c}\text { WY and dis- } \\
\text { charge }\left(\mathrm{ft}^{3} / \mathrm{s}\right) \\
\text { of maximum } \\
\text { peak }\end{array}$} \\
\hline & & & & & $\begin{array}{l}16,400 \\
17,700\end{array}$ & $\begin{array}{l}31,000 \\
31,000\end{array}$ & $\begin{array}{l}44,700 \\
43,800\end{array}$ & $\begin{array}{l}67,800 \\
67,700\end{array}$ & $\begin{array}{l}90,000 \\
80,700\end{array}$ & $\begin{array}{l}117,000 \\
106,000\end{array}$ & $\begin{array}{l}151,000 \\
137,000\end{array}$ & $\begin{array}{l}206,000 \\
188,000\end{array}$ & & & 1966 & 119,000 \\
\hline & & & & & \multicolumn{8}{|c|}{$\begin{array}{l}\text { Based on comparative analysis of unregulated and regulated periods of record for } \\
\text { stations below Loup R Power Canal, peak flows are not considered regulated, } \\
\text { although coded as such from } 1937 \text {. }\end{array}$} & & & & \\
\hline & 7947a & 06794710 & $\begin{array}{l}\text { Bone Cr near David City, Nebr. } \\
(-\quad-331 \text {-New station for East network analysis })\end{array}$ & PS & $\begin{array}{r}464 \\
1,010\end{array}$ & $\begin{array}{r}979 \\
2,300\end{array}$ & $\begin{array}{l}1,400 \\
3,400\end{array}$ & $\begin{array}{l}2,020 \\
5,050\end{array}$ & $\begin{array}{l}2,530 \\
6,450\end{array}$ & $\begin{array}{l}3,070 \\
7,970\end{array}$ & $\begin{array}{l}3,640 \\
9,670\end{array}$ & $\begin{array}{r}4,440 \\
12,100\end{array}$ & $\begin{array}{l}\text { LP3W } 11 \\
\text {-East- }\end{array}$ & $\begin{array}{l}1963, \\
1968-78\end{array}$ & 1963 & 20,900 \\
\hline & 7950 & 06795000 & $\begin{array}{l}\text { Shell Cr at Newman Grove, Nebr. } \\
(--0.250-\mathrm{NE})\end{array}$ & CR & $\begin{array}{l}1,730 \\
2,440\end{array}$ & $\begin{array}{l}5,160 \\
5,470\end{array}$ & $\begin{array}{l}8,860 \\
8,150\end{array}$ & $\begin{array}{l}15,400 \\
12,300\end{array}$ & $\begin{array}{l}21,800 \\
16,000\end{array}$ & $\begin{array}{l}29,500 \\
20,000\end{array}$ & $\begin{array}{l}38,700 \\
23,200\end{array}$ & $\begin{array}{l}53,300 \\
30,300\end{array}$ & $\begin{array}{l}\mathrm{LP} 3 \mathrm{~W} \\
-\mathrm{NE}-\end{array}$ & $\begin{array}{l}1950-67 \\
1969\end{array}$ & 1966 & 14,500 \\
\hline & 7955 & 06795500 & $\begin{array}{l}\text { Shell Cr near Columbus, Nebr. } \\
(-0.451 \text {-Skew map, NE }-0.380-\mathrm{NE})\end{array}$ & $\mathrm{CR}$ & $\begin{array}{l}1,520 \\
2,930\end{array}$ & $\begin{array}{l}2,810 \\
5,720\end{array}$ & $\begin{array}{l}3,770 \\
7,860\end{array}$ & $\begin{array}{r}5,050 \\
10,900\end{array}$ & $\begin{array}{r}6,030 \\
13,300\end{array}$ & $\begin{array}{r}7,020 \\
16,000\end{array}$ & $\begin{array}{r}8,030 \\
15,900\end{array}$ & $\begin{array}{r}9,400 \\
20,900\end{array}$ & $\begin{array}{l}\mathrm{LP} 3 \mathrm{~W} \\
-\mathrm{NE}-\end{array}$ & $\begin{array}{l}\text { 1947-75, } \\
1978-93\end{array}$ & 1990 & 8,000 \\
\hline & 7960 & 06796000 & $\begin{array}{l}\text { Platte } \mathrm{R} \text { at North Bend, Nebr. } \\
\left(70,400 \mathrm{mi}^{2} \text {, approximately, of which about } 57,800 \mathrm{mi}^{2} \mathrm{co}\right.\end{array}$ & $\begin{array}{l}\mathrm{CR} \\
\text { tributes }\end{array}$ & $\begin{array}{l}27,500 \\
\text { directly to }\end{array}$ & $\begin{array}{l}46,200 \\
\text { surface ru }\end{array}$ & $\begin{array}{l}61,800 \\
\text { noff) }\end{array}$ & 85,600 & 107,000 & 130,000 & 158,000 & 200,000 & REG 45 & 1949-93 & 1960 & 112,000 \\
\hline & 7969a & 06796973 & $\begin{array}{l}\text { Elkhorn R near Atkinson, Nebr. } \\
(-\stackrel{\longrightarrow}{\longrightarrow})\end{array}$ & CR & 1,000 & $\begin{aligned} 1,950 \\
\mathrm{Ap}\end{aligned}$ & $\begin{array}{l}2,740 \\
\text { ars to re } \\
\Gamma\end{array}$ & $\begin{array}{l}3,910 \\
\text { quire comp } \\
\text { lo basin ch }\end{array}$ & $\begin{array}{l}4,900 \\
\text { posite freq } \\
\text { haracteristi }\end{array}$ & $\begin{array}{l}\begin{array}{l}6,000 \\
\text { uency ana }\end{array} \\
\text { ics }\end{array}$ & $\begin{array}{l}7,200 \\
\text { lysis }\end{array}$ & 8,960 & LP3W 11 & 1983-93 & 1984 & 2,500 \\
\hline & $7969 \mathrm{~b}$ & 06796978 & $\begin{array}{l}\text { Holt Cr near Emmet, Nebr. } \\
\left(\begin{array}{r}-0.000-\text { New station for NE network analysis })\end{array}\right.\end{array}$ & $\mathrm{CR}$ & $\begin{array}{l}292 \\
343\end{array}$ & $\begin{array}{l}659 \\
785\end{array}$ & $\begin{array}{l}1,010 \\
1,250\end{array}$ & $\begin{array}{l}1,570 \\
2,090\end{array}$ & $\begin{array}{l}2,090 \\
2,920\end{array}$ & $\begin{array}{l}2,710 \\
3,920\end{array}$ & $\begin{array}{l}3,420 \\
5,590\end{array}$ & $\begin{array}{l}4,540 \\
7,580\end{array}$ & $\begin{array}{l}\mathrm{LP} 3 \mathrm{~W} \\
-\mathrm{NE}-\end{array}$ & 1979-89 & 1987 & 948 \\
\hline & 7975 & 06797500 & $\begin{array}{l}\text { Elkhorn R at Ewing, Nebr. } \\
(-0.149 \text {-Skew map, NE }+0.330-\text { HPS, NE) }\end{array}$ & $\mathrm{CR}$ & $\begin{array}{l}1,240 \\
1,230 \\
1,470\end{array}$ & $\begin{array}{l}3,120 \\
2,830 \\
3,250\end{array}$ & $\begin{array}{l}5,190 \\
3,530 \\
5,060\end{array}$ & $\begin{array}{l}9,080 \\
4,920 \\
8,200\end{array}$ & $\begin{array}{r}13,200 \\
7,370 \\
11,300\end{array}$ & $\begin{array}{r}18,600 \\
8,740 \\
15,000\end{array}$ & $\begin{array}{l}25,600 \\
10,300 \\
21,800\end{array}$ & $\begin{array}{l}37,900 \\
12,800 \\
28,700\end{array}$ & $\begin{array}{c}\text { LP3W } 47 \\
\text { - } 4 \text {-NE- }\end{array}$ & 1947-93 & 1962 & 7,500 \\
\hline & 7980 & 06798000 & $\begin{array}{l}\text { S Fk Elkhorn } \mathrm{R} \text { at Ewing, Nebr. } \\
(+0.205-\text { Skew map, NE }+0.202-\mathrm{HPS}, \mathrm{NE})\end{array}$ & CR & $\begin{array}{l}487 \\
428 \\
459\end{array}$ & $\begin{array}{r}1,200 \\
964 \\
1,050\end{array}$ & $\begin{array}{l}1,960 \\
1,220 \\
1,670\end{array}$ & $\begin{array}{l}3,360 \\
2,000 \\
2,800\end{array}$ & $\begin{array}{l}4,800 \\
3,270 \\
3,930\end{array}$ & $\begin{array}{l}6,660 \\
4,000 \\
5,340\end{array}$ & $\begin{array}{l}9,030 \\
4,860 \\
7,950\end{array}$ & $\begin{array}{r}13,100 \\
6,240 \\
10,700\end{array}$ & $\begin{array}{l}\text { LP3W } 38 \\
\text {-HPS- } \\
-\mathrm{NE}-\end{array}$ & $\begin{array}{l}1947-53, \\
1961-72, \\
1978-93\end{array}$ & 1987 & 5,640 \\
\hline & 7983 & 06798300 & $\begin{array}{l}\text { Clearwater Cr near Clearwater, Nebr. } \\
(-+0.263-\mathrm{HPS}, \mathrm{NE})\end{array}$ & CR & $\begin{array}{l}344 \\
306 \\
636\end{array}$ & $\begin{array}{r}656 \\
726 \\
1,620\end{array}$ & $\begin{array}{r}935 \\
1,130 \\
2,750\end{array}$ & $\begin{array}{l}1,380 \\
2,110 \\
4,900\end{array}$ & $\begin{array}{l}1,790 \\
3,870 \\
7,150\end{array}$ & $\begin{array}{r}2,280 \\
4,960 \\
10,100\end{array}$ & $\begin{array}{r}2,850 \\
6,270 \\
17,100\end{array}$ & $\begin{array}{r}3,760 \\
8,440 \\
22,600\end{array}$ & $\begin{array}{c}\mathrm{LP} 3 \mathrm{~W} \\
\text { - } 19 \\
-\mathrm{NE}-\end{array}$ & $\begin{array}{l}\text { 1962-64, } \\
1978-93\end{array}$ & 1987 & 1,510 \\
\hline & 7985 & 06798500 & $\begin{array}{l}\text { Elkhorn } R \text { at Neligh, Nebr. } \\
(+0.045-\text { Skew map, NE }+0.066-\mathrm{HPS}, \mathrm{NE})\end{array}$ & $\mathrm{CR}$ & $\begin{array}{l}1,840 \\
1,800 \\
2,280\end{array}$ & $\begin{array}{l}4,100 \\
4,180 \\
5,040\end{array}$ & $\begin{array}{l}6,260 \\
5,280 \\
7,810\end{array}$ & $\begin{array}{r}9,880 \\
7,790 \\
12,600\end{array}$ & $\begin{array}{l}13,300 \\
11,800 \\
17,200\end{array}$ & $\begin{array}{l}17,400 \\
14,200 \\
22,900\end{array}$ & $\begin{array}{l}22,300 \\
17,000 \\
33,600\end{array}$ & $\begin{array}{l}30,100 \\
21,300 \\
43,800\end{array}$ & $\begin{array}{c}\text { LP3W } \quad 78 \\
\text { - } \mathrm{HPS}- \\
\text { NE- }\end{array}$ & $\begin{array}{l}\text { 1932-58, } \\
1960-93\end{array}$ & 1987 & 14,100 \\
\hline & 7990 & 06799000 & $\begin{array}{l}\text { Elkhorn } R \text { at Norfolk, Nebr. } \\
(-0.163 \text {-Skew map, NE }-0.005-H P S, N E)\end{array}$ & CR & $\begin{array}{l}4,430 \\
3,180 \\
2,940\end{array}$ & $\begin{array}{l}8,560 \\
6,920 \\
6,350\end{array}$ & $\begin{array}{r}12,000 \\
9,730 \\
9,670\end{array}$ & $\begin{array}{l}17,300 \\
13,900 \\
15,300\end{array}$ & $\begin{array}{l}21,800 \\
19,800 \\
20,600\end{array}$ & $\begin{array}{l}26,800 \\
24,400 \\
27,100\end{array}$ & $\begin{array}{l}32,500 \\
29,900 \\
38,500\end{array}$ & $\begin{array}{l}40,800 \\
38,500 \\
49,900\end{array}$ & $\begin{array}{c}\text { LP3W } 61 \\
\text {-HPS- } \\
\text {-NE- }\end{array}$ & $\begin{array}{l}\text { 1897-1903, } \\
1940-93\end{array}$ & 1967 & 16,900 \\
\hline & $7990 \mathrm{~b}$ & 06799080 & $\begin{array}{l}\text { Willow Cr near Foster, Nebr. } \\
(-+0.233-\mathrm{NE})\end{array}$ & $\mathrm{CR}$ & $\begin{array}{l}141 \\
252\end{array}$ & $\begin{array}{l}327 \\
572\end{array}$ & $\begin{array}{l}515 \\
908\end{array}$ & $\begin{array}{r}849 \\
1,490\end{array}$ & $\begin{array}{l}1,180 \\
2,060\end{array}$ & $\begin{array}{l}1,600 \\
2,740\end{array}$ & $\begin{array}{l}2,100 \\
3,640\end{array}$ & $\begin{array}{l}3,000 \\
4,980\end{array}$ & $\begin{array}{l}\mathrm{LP} 3 \mathrm{~W} \\
-\mathrm{NE}-\end{array}$ & 1976-93 & 1987 & 574 \\
\hline & 7991 & 06799100 & $\begin{array}{l}\text { N Fk Elkhorn R near Pierce, Nebr. } \\
(-\quad+0.118-\mathrm{HPS}, \mathrm{NE})\end{array}$ & $\mathrm{CR}$ & $\begin{array}{l}1,400 \\
1,800 \\
2,760\end{array}$ & $\begin{array}{l}3,500 \\
3,700 \\
6,760\end{array}$ & $\begin{array}{r}5,800 \\
7,400 \\
10,900\end{array}$ & $\begin{array}{r}9,800 \\
12,600 \\
18,200\end{array}$ & $\begin{array}{l}13,900 \\
19,200 \\
25,200\end{array}$ & $\begin{array}{l}19,100 \\
26,300 \\
33,700\end{array}$ & $\begin{array}{l}25,600 \\
35,100 \\
49,100\end{array}$ & $\begin{array}{l}36,800 \\
50,200 \\
63,600\end{array}$ & $\begin{array}{c}\text { LP3W } 33 \\
\text {-HPS- } \\
\text {-NE- }\end{array}$ & $1961-93$ & 1971 & 15,200 \\
\hline & $7991 \mathrm{~b}$ & 06799190 & $\begin{array}{l}\text { S Fk Union Cr trib near Cornlea, Nebr. } \\
\left(\begin{array}{r}-0.179-\text { New station for NE network analysis })\end{array}\right.\end{array}$ & $\mathrm{CR}$ & 523 & $\begin{array}{l}1,140 \\
\text { Basin }\end{array}$ & $\begin{array}{c}1,680 \\
\text { character }\end{array}$ & $\begin{array}{l}2,500 \\
\text { tic(s) out }\end{array}$ & $\begin{array}{l}3,210 \\
\text { tside of ran }\end{array}$ & $\begin{array}{l}4,010 \\
\text { ne for equ }\end{array}$ & $\begin{array}{l}4,880 \\
\text { uations }\end{array}$ & 6,170 & $\begin{array}{l}\mathrm{LP} 3 \mathrm{~W} \\
-\mathrm{NE}-\end{array}$ & 1967-78 & 1977 & 1,830 \\
\hline
\end{tabular}


Table B2. Peak-flow frequency data for streamflow-gaging stations in Nebraska and for selected out-of-state stations,

and drainage areas for regulated streams--Continued

\begin{tabular}{|c|c|c|c|c|c|c|c|c|c|c|c|c|c|c|c|}
\hline \multirow{2}{*}{$\begin{array}{c}\begin{array}{c}\text { Map } \\
\text { num- } \\
\text { ber }\end{array} \\
7992 \mathrm{a}\end{array}$} & \multirow{2}{*}{$\begin{array}{c}\begin{array}{c}\text { Station } \\
\text { number }\end{array} \\
06799230\end{array}$} & \multirow{2}{*}{ 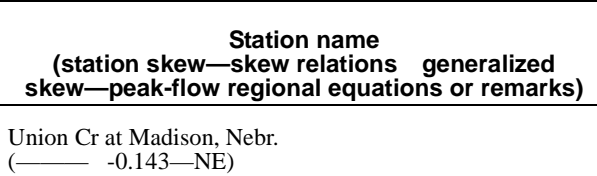 } & \multirow{2}{*}{$\begin{array}{l}\text { Gage } \\
\text { type }\end{array}$} & \multicolumn{8}{|c|}{$\begin{array}{l}\text { Peak discharge }\left(\mathrm{ft}^{3} / \mathbf{s}\right) \text { for given recurrence interval (years) } \\
\text { and/or remarks }\end{array}$} & \multirow{2}{*}{$\begin{array}{c}\begin{array}{c}\text { Type and length } \\
\text { (years) of analysis } \\
\text {-regional } \\
\text { equation- }\end{array} \\
\begin{array}{c}\text { LP3W } 15 \\
-\mathrm{NE}-\end{array}\end{array}$} & \multirow{2}{*}{$\begin{array}{c}\begin{array}{c}\text { Period of } \\
\text { peak-flow } \\
\text { record }\end{array} \\
1979-93\end{array}$} & \multicolumn{2}{|c|}{$\begin{array}{c}\text { WY and dis- } \\
\text { charge }\left(\mathrm{ft}^{3} / \mathrm{s}\right) \\
\text { of maximum } \\
\text { peak }\end{array}$} \\
\hline & & & & $\begin{array}{l}2,070 \\
2,490\end{array}$ & $\begin{array}{l}6,740 \\
5,670\end{array}$ & $\begin{array}{r}12,200 \\
8,560\end{array}$ & $\begin{array}{l}22,600 \\
13,000\end{array}$ & $\begin{array}{l}33,300 \\
16,800\end{array}$ & $\begin{array}{l}46,879 \\
21,000\end{array}$ & $\begin{array}{l}63,805 \\
23,500\end{array}$ & $\begin{array}{l}92,090 \\
30,900\end{array}$ & & & 1990 & 15,100 \\
\hline 7993a & 06799350 & $\begin{array}{l}\text { Elkhorn } R \text { at West Point, Nebr. } \\
(-0.202-\text { Skew map, NE }-0.061-\text { HPS, NE) }\end{array}$ & CR & $\begin{array}{r}11,200 \\
7,870 \\
5,140\end{array}$ & $\begin{array}{l}21,600 \\
16,300 \\
10,800\end{array}$ & $\begin{array}{l}30,300 \\
26,200 \\
16,200\end{array}$ & $\begin{array}{l}43,200 \\
37,800 \\
24,800\end{array}$ & $\begin{array}{l}54,100 \\
51,300 \\
32,800\end{array}$ & $\begin{array}{l}66,200 \\
66,000 \\
42,100\end{array}$ & $\begin{array}{l}79,600 \\
83,300 \\
56,500\end{array}$ & $\begin{array}{r}99,300 \\
111,000 \\
72,800\end{array}$ & $\begin{array}{l}\text { LP3W } 33 \\
\text {-HPS- } \\
-\mathrm{NE}-\end{array}$ & $1961-93$ & 1967 & 44,000 \\
\hline 7993b & 06799385 & 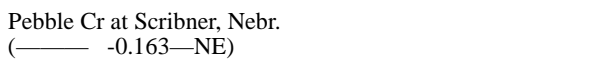 & $\mathrm{CR}$ & $\begin{array}{l}7,270 \\
3,730\end{array}$ & $\begin{array}{r}14,700 \\
7,880\end{array}$ & $\begin{array}{l}21,100 \\
11,200\end{array}$ & $\begin{array}{l}30,700 \\
16,100\end{array}$ & $\begin{array}{l}38,900 \\
20,000\end{array}$ & $\begin{array}{l}48,000 \\
24,200\end{array}$ & $\begin{array}{l}58,100 \\
24,800\end{array}$ & $\begin{array}{l}73,000 \\
32,400\end{array}$ & $\begin{array}{l}\mathrm{LP} 3 \mathrm{~W} \\
-\mathrm{NE}-\end{array}$ & 1979-93 & 1991 & 27,900 \\
\hline 7994a & 06799423 & 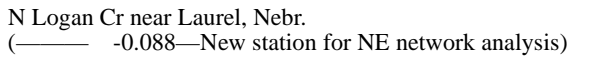 & PS & $\begin{array}{l}330 \\
447\end{array}$ & $\begin{array}{r}1,150 \\
999 \\
\mathrm{Ap}\end{array}$ & $\begin{array}{l}2,180 \\
1,490 \\
\text { pears to re }\end{array}$ & $\begin{array}{r}4,300 \\
2,290 \\
\text { equire com }\end{array}$ & $\begin{array}{r}6,640 \\
3,010 \\
\text { posite frec }\end{array}$ & $\begin{array}{r}9,800 \\
3,800 \\
\text { uency ana }\end{array}$ & $\begin{array}{r}13,900 \\
4,220 \\
\text { lysis }\end{array}$ & $\begin{array}{r}21,400 \\
5,720\end{array}$ & $\begin{array}{l}\mathrm{LP} 3 \mathrm{~W} \\
-\mathrm{NE}-\end{array}$ & $\begin{array}{l}1965, \\
1967-78\end{array}$ & 1971 & 3,020 \\
\hline 7994b & 06799450 & $\begin{array}{l}\text { Logan } \mathrm{Cr} \text { at Pender, Nebr. } \\
(-0.454-\text { Skew map, NE }-0.318-\mathrm{NE})\end{array}$ & $\mathrm{CR}$ & $\begin{array}{l}6,830 \\
5,870\end{array}$ & $\begin{array}{l}14,100 \\
12,200\end{array}$ & $\begin{array}{l}20,000 \\
17,400\end{array}$ & $\begin{array}{l}28,600 \\
24,800\end{array}$ & $\begin{array}{l}35,500 \\
30,900\end{array}$ & $\begin{array}{l}43,000 \\
37,400\end{array}$ & $\begin{array}{l}50,800 \\
38,900\end{array}$ & $\begin{array}{l}61,700 \\
50,500\end{array}$ & $\begin{array}{l}\mathrm{LP} 3 \mathrm{~W} \\
-\mathrm{NE}-\end{array}$ & $1966-93$ & 1971 & 36,900 \\
\hline 7995 & 06799500 & $\begin{array}{l}\text { Logan Cr near Uehling, Nebr. } \\
(-0.400 \text {-Skew map, NE }-0.370-\mathrm{NE})\end{array}$ & $\mathrm{CR}$ & $\begin{array}{l}6,090 \\
6,160\end{array}$ & $\begin{array}{l}11,300 \\
11,900\end{array}$ & $\begin{array}{l}15,200 \\
16,100\end{array}$ & $\begin{array}{l}20,300 \\
21,900\end{array}$ & $\begin{array}{l}24,300 \\
26,300\end{array}$ & $\begin{array}{l}28,300 \\
30,900\end{array}$ & $\begin{array}{l}32,300 \\
29,200\end{array}$ & $\begin{array}{l}37,600 \\
38,100\end{array}$ & $\stackrel{\mathrm{LP} 3 \mathrm{~W}}{-\mathrm{NE}-}$ & $1940-93$ & 1971 & 25,200 \\
\hline 7998a & 06799850 & $\begin{array}{l}\text { Pond Cr near Schuyler, Nebr. } \\
(-\end{array}$ & PS & 10 & 92 & 262 & $\begin{array}{c}741 \\
T D A\end{array}$ & $\begin{aligned} 1,390 \\
1 \mathrm{mi}^{2}\end{aligned}$ & 2,400 & 3,850 & 6,670 & LP3W 10 & $1968-78$ & 1972 & 500 \\
\hline 8000 & 06800000 & $\begin{array}{l}\text { Maple Cr near Nickerson, Nebr. } \\
(-0.288 \text {-Skew map, NE }-0.406-\mathrm{NE})\end{array}$ & $\mathrm{CR}$ & $\begin{array}{l}2,930 \\
3,750\end{array}$ & $\begin{array}{l}5,520 \\
7,400\end{array}$ & $\begin{array}{r}7,460 \\
10,200\end{array}$ & $\begin{array}{l}10,100 \\
14,000\end{array}$ & $\begin{array}{l}12,100 \\
17,100\end{array}$ & $\begin{array}{l}14,200 \\
20,400\end{array}$ & $\begin{array}{l}16,300 \\
19,900\end{array}$ & $\begin{array}{l}19,200 \\
26,000\end{array}$ & $\begin{array}{l}\mathrm{LP} 3 \mathrm{~W} \\
-\mathrm{NE}-\end{array}$ & $\begin{array}{l}1944, \\
1952-93\end{array}$ & 1944 & 35,000 \\
\hline $8003 \mathrm{a}$ & 06800350 & $\begin{array}{l}\text { Elkhorn R trib near Nickerson, Nebr. } \\
(-\quad+0.112-\text { New station for NE network analysis })\end{array}$ & PS & 60 & $\begin{array}{l}188 \\
\text { Basin }\end{array}$ & $\begin{array}{c}344 \\
\text { character }\end{array}$ & $\begin{aligned} 658 \\
\text { istic(s) ou }\end{aligned}$ & $\begin{array}{l}1,000 \\
\text { ide of rat }\end{array}$ & $\begin{array}{l}1,470 \\
\text { ge for equ }\end{array}$ & $\begin{array}{l}2,100 \\
\text { rations }\end{array}$ & 3,220 & $\begin{array}{l}\mathrm{LP} 3 \mathrm{~W} \\
-\mathrm{NE}-\end{array}$ & $1968-78$ & 1975 & 225 \\
\hline 8005 & 06800500 & $\begin{array}{l}\text { Elkhorn } R \text { at Waterloo, Nebr. } \\
(+0.080-\text { Skew map, NE }-0.107-H P S, N E)\end{array}$ & $\mathrm{CR}$ & $\begin{array}{r}12,200 \\
12,500 \\
8,940\end{array}$ & $\begin{array}{l}23,000 \\
25,100 \\
18,400\end{array}$ & $\begin{array}{l}32,000 \\
44,600 \\
26,600\end{array}$ & $\begin{array}{l}45,200 \\
65,900 \\
39,600\end{array}$ & $\begin{array}{l}56,500 \\
87,600 \\
51,100\end{array}$ & $\begin{array}{r}69,000 \\
116,000 \\
64,400\end{array}$ & $\begin{array}{r}82,700 \\
150,000 \\
81,500\end{array}$ & $\begin{array}{l}103,000 \\
206,000 \\
104,000\end{array}$ & $\begin{array}{c}\mathrm{LP3W} 113 \\
\text { - } \mathrm{HPS}- \\
-\mathrm{NE}-\end{array}$ & $\begin{array}{l}\text { 1881, } \\
\text { 1899-1903 } \\
1911-15, \\
1929-93\end{array}$ & 1944 & 100,000 \\
\hline 8010 & 06801000 & $\begin{array}{l}\text { Platte R near Ashland, Nebr. } \\
\left(84,200 \mathrm{mi}^{2} \text {, from state base maps, scale }-100,000\right)\end{array}$ & $\mathrm{CR}$ & 43,900 & 64,700 & 79,900 & 101,000 & 117,000 & 135,000 & 153,000 & 180,000 & REG 30 & $\begin{array}{l}1929-53 \\
1989-93\end{array}$ & 1993 & 130,000 \\
\hline 8030 & 06803000 & $\begin{array}{l}\text { Salt Cr at Roca, Nebr. } \\
(-\quad-0.548 \text {-East) }\end{array}$ & $\mathrm{CR}$ & $\begin{array}{l}4,040 \\
6,890 \\
1,590 \\
\quad \mathrm{Ur}\end{array}$ & $\begin{array}{r}9,550 \\
14,800 \\
3,860 \\
\text { regulated }\end{array}$ & $\begin{array}{c}14,300 \\
20,900 \\
6,040 \\
\text { prior to } 1\end{array}$ & $\begin{array}{r}21,100 \\
29,200 \\
9,640 \\
963 ; 30 \mathrm{pe}\end{array}$ & $\begin{array}{l}26,700 \\
35,600 \\
13,000 \\
\text { cent of bi }\end{array}$ & $\begin{array}{l}32,500 \\
42,300 \\
16,800 \\
\text { sin regulat }\end{array}$ & $\begin{array}{l}38,600 \\
49,100 \\
21,300 \\
\text { d after } 1\end{array}$ & $\begin{array}{r}47,000 \\
58,400 \\
28,300 \\
964\end{array}$ & $\begin{array}{l}\text { LP3W } 54 \\
\text { EEG } \quad 54-\frac{19}{\text { REG }}\end{array}$ & $1950-93$ & 1950 & 67,000 \\
\hline 8032 & 06803200 & Antelope $\mathrm{Cr}$ at 48 th Street, Lincoln, Nebr. $\quad\left(7.14 \mathrm{mi}^{2}\right)$ & PS & 503 & 958 & 1,330 & 1,860 & 2,300 & 2,780 & 3,290 & 4,030 & REG 17 & 1958-78 & 1958 & 3,300 \\
\hline 8033 & 06803300 & Antelope $\mathrm{Cr}$ at 27th Street, Lincoln, Nebr. $\quad\left(10.6 \mathrm{mi}^{2}\right)$ & PS & 994 & 1,610 & 2,000 & 2,480 & 2,820 & 3,130 & 3,430 & 3,810 & REG 17 & 1957-78 & 1958 & 2,570 \\
\hline 8034 & 06803400 & Antelope $\mathrm{Cr}$ at Lincoln, Nebr. $\quad\left(12.1 \mathrm{mi}^{2}\right)$ & PS & 1,230 & 1,960 & 2,540 & 3,390 & 4,100 & 4,900 & 5,790 & 7,120 & REG 17 & $1958-78$ & 1967 & 3,370 \\
\hline 8035 & 06803500 & $\begin{array}{l}\text { Salt } \mathrm{Cr} \text { at Lincoln, Nebr. } \quad\left(685 \mathrm{mi}^{2}\right) \\
(\square)\end{array}$ & $\mathrm{CR}$ & $\begin{array}{l}8,750 \\
7,820 \\
\text { Ur } \\
\text { Appea }\end{array}$ & $\begin{array}{l}16,500 \\
14,500\end{array}$ & $\begin{array}{l}22,300 \\
18,900 \\
\text { prior to } 1 \text {. }\end{array}$ & $\begin{array}{c}30,200 \\
24,100 \\
962 ; 31 \mathrm{pe}\end{array}$ & $\begin{array}{l}36,300 \\
27,700 \\
\text { cent of } b\end{array}$ & $\begin{array}{l}42,500 \\
31,000\end{array}$ & $\begin{array}{l}48,800 \\
34,000\end{array}$ & $\begin{array}{r}57,300 \\
37,600 \\
967\end{array}$ & $\begin{array}{lc}\text { LP3W } & 101 \\
\text { REG } & 132\end{array}$ & $\begin{array}{l}1908, \\
1950-93\end{array}$ & 1993 & 28,400 \\
\hline $8035 b$ & 06803510 & $\begin{array}{l}\text { Little Salt Cr near Lincoln, Nebr. } \\
(-0.205 \text {-Skew map, SE }-0.313 \text {-East })\end{array}$ & $\mathrm{CR}$ & $\begin{array}{l}1,770 \\
2,140\end{array}$ & $\begin{array}{l}4,180 \\
4,870\end{array}$ & $\begin{array}{l}6,380 \\
7,170\end{array}$ & $\begin{array}{r}9,820 \\
10,500\end{array}$ & $\begin{array}{l}12,800 \\
13,400\end{array}$ & $\begin{array}{l}16,200 \\
16,500\end{array}$ & $\begin{array}{l}20,000 \\
19,900\end{array}$ & $\begin{array}{l}25,500 \\
24,700\end{array}$ & $\begin{array}{l}\text { LP3W } 25 \\
\text {-East- }\end{array}$ & 1969-93 & 1993 & 8,480 \\
\hline
\end{tabular}


Table B2. Peak-flow frequency data for streamflow-gaging stations in Nebraska and for selected out-of-state stations,

and drainage areas for regulated streams--Continued

\begin{tabular}{|c|c|c|c|c|c|c|c|c|c|c|c|c|c|c|c|c|}
\hline \multirow{20}{*}{ 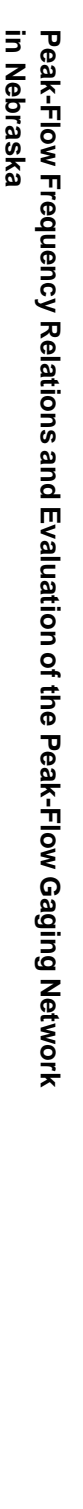 } & \multirow{2}{*}{$\begin{array}{r}\begin{array}{c}\text { Map } \\
\text { num- } \\
\text { ber }\end{array} \\
8035 \mathrm{c}\end{array}$} & \multirow{2}{*}{$\begin{array}{c}\begin{array}{c}\text { Station } \\
\text { number }\end{array} \\
06803520\end{array}$} & \multirow{2}{*}{$\begin{array}{c}\begin{array}{c}\text { Station name } \\
\text { (station skew-skew relations } \\
\text { skew-peak-flow regional equations or remarks) }\end{array} \\
\text { Stevens Cr near Lincoln, Nebr. } \\
(-0.528 \text {-Skew map, SE -0.329—East) }\end{array}$} & \multirow{2}{*}{$\begin{array}{c}\begin{array}{c}\text { Gage } \\
\text { type }\end{array} \\
\mathrm{CR}\end{array}$} & \multicolumn{8}{|c|}{$\begin{array}{c}\left.\text { Peak discharge ( } \mathrm{ft}^{3} / \mathrm{s}\right) \text { for given recurrence interval (years) } \\
\text { and/or remarks }\end{array}$} & \multirow{2}{*}{$\begin{array}{c}\begin{array}{c}\text { Type and length } \\
\text { (years) of analysis } \\
\text { - regional } \\
\text { equation- }\end{array} \\
\begin{array}{c}\text { LP3W 25 } \\
\text {-East- }\end{array}\end{array}$} & \multirow{2}{*}{$\begin{array}{c}\begin{array}{c}\text { Period of } \\
\text { peak-flow } \\
\text { record }\end{array} \\
1969-93\end{array}$} & \multicolumn{2}{|c|}{$\begin{array}{c}\text { WY and dis- } \\
\left.\text { charge (ft }{ }^{3} / \mathbf{s}\right) \\
\text { of maximum } \\
\text { peak }\end{array}$} \\
\hline & & & & & $\begin{array}{l}1,680 \\
2,330\end{array}$ & $\begin{array}{l}4,690 \\
5,230\end{array}$ & $\begin{array}{l}7,690 \\
7,640\end{array}$ & $\begin{array}{l}12,700 \\
11,200\end{array}$ & $\begin{array}{l}17,200 \\
14,100\end{array}$ & $\begin{array}{l}22,400 \\
17,400\end{array}$ & $\begin{array}{l}28,300 \\
20,800\end{array}$ & $\begin{array}{l}37,100 \\
25,800\end{array}$ & & & 1989 & 12,900 \\
\hline & $8035 \mathrm{~d}$ & 06803530 & $\begin{array}{l}\text { Rock Cr near Ceresco, Nebr. } \\
(+0.405 \text {-Skew map - } 0.273 \text {-East })\end{array}$ & $\mathrm{CR}$ & $\begin{array}{l}2,950 \\
3,420\end{array}$ & $\begin{array}{l}6,170 \\
7,550\end{array}$ & $\begin{array}{r}8,890 \\
11,000\end{array}$ & $\begin{array}{l}13,000 \\
16,000\end{array}$ & $\begin{array}{l}16,400 \\
20,200\end{array}$ & $\begin{array}{l}20,200 \\
24,700\end{array}$ & $\begin{array}{l}24,300 \\
29,600\end{array}$ & $\begin{array}{l}30,200 \\
36,700\end{array}$ & $\begin{array}{l}\text { LP3W } 24 \\
\text {-East- }\end{array}$ & $1970-93$ & 1987 & 23,300 \\
\hline & $8035 \mathrm{e}$ & 06803540 & $\begin{array}{l}\text { Dee Cr near Alvo, Nebr. } \\
(--0.253 \text {-East })\end{array}$ & PS & $\begin{array}{r}1,010 \\
780\end{array}$ & $\begin{array}{l}2,200 \\
1,840 \\
A p\end{array}$ & $\begin{array}{l}3,220 \\
2,770 \\
\text { pears to rec }\end{array}$ & $\begin{array}{c}4,740 \\
4,200 \\
\text { equire com! }\end{array}$ & $\begin{array}{r}6,030 \\
5,440 \\
\text { posite fred }\end{array}$ & $\begin{array}{r}7,430 \\
6,830 \\
\text { uency ana }\end{array}$ & $\begin{array}{r}8,950 \\
8,380 \\
\text { sis }\end{array}$ & $\begin{array}{l}11,100 \\
10,700\end{array}$ & $\begin{array}{l}\text { LP3W } \\
\text {-East- }\end{array}$ & $1962-78$ & 1978 & 2,800 \\
\hline & $8035 \mathrm{f}$ & 06803555 & $\begin{array}{l}\text { Salt } \mathrm{Cr} \text { at Greenwood, Nebr. } \quad\left(1,050 \mathrm{mi}^{2}\right) \\
(-)\end{array}$ & $\mathrm{CR}$ & $\begin{array}{l}11,700 \\
13,400\end{array}$ & $\begin{array}{l}24,900 \\
31,600\end{array}$ & $\begin{array}{l}36,100 \\
45,900\end{array}$ & $\begin{array}{l}52,800 \\
65,000\end{array}$ & $\begin{array}{l}67,000 \\
79,200\end{array}$ & $\begin{array}{l}82,400 \\
93,100\end{array}$ & $\begin{array}{r}99,200 \\
106,000\end{array}$ & $\begin{array}{l}123,000 \\
123,000\end{array}$ & $\begin{array}{cc}\text { LP3W } & 11 \\
\text { REG } & 26\end{array}$ & 1952-93 & 1984 & 46,800 \\
\hline & & & & & $\begin{aligned} & \text { Un } \\
& \text { Appea }\end{aligned}$ & $\begin{array}{l}\text { nregulated } \\
\text { ars to requ }\end{array}$ & $\begin{array}{l}\text { 1 prior to } 19 \\
\text { ire compos }\end{array}$ & $\begin{array}{l}962 ; 20 \text { per } \\
\text { site frequen }\end{array}$ & $\begin{array}{l}\text { rcent of be } \\
\text { hey analys }\end{array}$ & $\begin{array}{l}\text { sin regula } \\
\text { is No ba }\end{array}$ & $\begin{array}{l}\text { ted after } 1 \text { t } \\
\text { sin charact }\end{array}$ & $\begin{array}{l}967 \\
\text { teristics }\end{array}$ & & & & \\
\hline & $8035 \mathrm{~g}$ & 06803570 & $\begin{array}{l}\text { Dunlap Cr trib near Weston, Nebr. } \\
(-0.128 \text {-Skew map } \longrightarrow)\end{array}$ & PS & 245 & 453 & 607 & $\begin{array}{l}814 \\
T D A\end{array}$ & $<1 \mathrm{mi}^{974}$ & 1,140 & 1,300 & 1,520 & LP3W 29 & 1950-78 & 1963 & 923 \\
\hline & 8036 & 06803600 & $\begin{array}{l}\text { N Fk Wahoo Cr near Prague, Nebr. } \\
(-0.524-\text { Skew map, SE }-0.440 \text {-East })\end{array}$ & PS & $\begin{array}{l}1,420 \\
1,660\end{array}$ & $\begin{array}{l}4,350 \\
3,650\end{array}$ & $\begin{array}{l}7,380 \\
5,270\end{array}$ & $\begin{array}{r}12,400 \\
7,620\end{array}$ & $\begin{array}{r}17,000 \\
9,570\end{array}$ & $\begin{array}{l}22,000 \\
11,700\end{array}$ & $\begin{array}{l}27,900 \\
13,900\end{array}$ & $\begin{array}{l}36,400 \\
17,100\end{array}$ & $\begin{array}{l}\text { LP3W } 135 \\
\text {-East- }\end{array}$ & $1951-78$ & 1963 & 15,900 \\
\hline & 8037 & 06803700 & $\begin{array}{l}\text { N Fk Wahoo Cr trib near Weston, Nebr. } \\
(--0.414 \text {-East })\end{array}$ & PS & $\begin{array}{l}1,330 \\
1,100\end{array}$ & $\begin{array}{l}2,780 \\
2,540\end{array}$ & $\begin{array}{l}3,960 \\
3,760\end{array}$ & $\begin{array}{l}5,650 \\
5,550\end{array}$ & $\begin{array}{l}7,020 \\
7,070\end{array}$ & $\begin{array}{l}8,470 \\
8,730\end{array}$ & $\begin{array}{r}9,990 \\
10,500\end{array}$ & $\begin{array}{l}12,100 \\
13,100\end{array}$ & $\begin{array}{l}\text { LP3W } 79 \\
\text {-East- }\end{array}$ & $1950-67$ & 1963 & 13,800 \\
\hline & 8039 & 06803900 & $\begin{array}{l}\text { N Fk Wahoo Cr at Weston, Nebr. } \\
(-0.104 \text {-Skew map }-0.438 \text {-East })\end{array}$ & PS & $\begin{array}{l}1,560 \\
2,830\end{array}$ & $\begin{array}{l}4,440 \\
6,080\end{array}$ & $\begin{array}{l}7,320 \\
8,690\end{array}$ & $\begin{array}{l}12,100 \\
12,400\end{array}$ & $\begin{array}{l}16,400 \\
15,500\end{array}$ & $\begin{array}{l}21,400 \\
18,700\end{array}$ & $\begin{array}{l}27,000 \\
22,100\end{array}$ & $\begin{array}{l}35,400 \\
26,900\end{array}$ & $\begin{array}{l}\text { LP3W } 77 \\
\text {-East- }\end{array}$ & $1951-78$ & 1963 & 81,400 \\
\hline & 8040 & 06804000 & $\begin{array}{l}\text { Wahoo Cr at Ithaca, Nebr. } \\
(+0.018 \text { - Skew map* }-0.345 \text {-East }) \\
* \text { Should have been used for development of SE equation }\end{array}$ & $\mathrm{CR}$ & $\begin{array}{l}4,200 \\
6,580\end{array}$ & $\begin{array}{r}9,400 \\
13,700\end{array}$ & $\begin{array}{l}14,100 \\
19,400\end{array}$ & $\begin{array}{l}21,200 \\
27,300\end{array}$ & $\begin{array}{l}27,400 \\
33,700\end{array}$ & $\begin{array}{l}34,400 \\
40,500\end{array}$ & $\begin{array}{l}42,000 \\
47,600\end{array}$ & $\begin{array}{l}53,400 \\
57,600\end{array}$ & $\begin{array}{l}\text { LP3W } 150 \\
\text {-East- }\end{array}$ & $1950-93$ & 1963 & 77,400 \\
\hline & 8041 & 06804100 & $\begin{array}{l}\text { Silver Cr near Cedar Bluffs, Nebr. } \\
(-0.004 \text {-Skew map, SE -0.113-East })\end{array}$ & PS & $\begin{array}{l}475 \\
437\end{array}$ & $\begin{array}{l}1,100 \\
1,080\end{array}$ & $\begin{array}{l}1,690 \\
1,690\end{array}$ & $\begin{array}{l}2,620 \\
2,660\end{array}$ & $\begin{array}{l}3,450 \\
3,560\end{array}$ & $\begin{array}{l}4,410 \\
4,610\end{array}$ & $\begin{array}{l}5,500 \\
5,820\end{array}$ & $\begin{array}{l}7,150 \\
7,700\end{array}$ & $\begin{array}{l}\text { LP3W } 84 \\
\text {-East- }\end{array}$ & $1950-78$ & 1959 & 4,040 \\
\hline & 8042 & 06804200 & $\begin{array}{l}\text { Silver Cr near Colon, Nebr. } \\
(+0.014 \text {-Skew map, SE -0.127-East })\end{array}$ & PS & $\begin{array}{l}600 \\
842\end{array}$ & $\begin{array}{l}1,840 \\
2,130\end{array}$ & $\begin{array}{l}3,250 \\
3,330\end{array}$ & $\begin{array}{l}5,940 \\
5,230\end{array}$ & $\begin{array}{l}8,710 \\
6,940\end{array}$ & $\begin{array}{r}12,300 \\
8,920\end{array}$ & $\begin{array}{l}16,700 \\
11,200\end{array}$ & $\begin{array}{l}24,300 \\
14,700\end{array}$ & $\begin{array}{l}\text { LP3W } 84 \\
\text {-East- }\end{array}$ & $1950-78$ & 1959 & 12,000 \\
\hline & 8043 & 06804300 & $\begin{array}{l}\text { Silver Cr trib near Colon, Nebr. } \\
(+0.115 \text {-Skew map, SE }-0.077 \text {-East })\end{array}$ & PS & $\begin{array}{r}77 \\
204\end{array}$ & $\begin{array}{l}270 \\
610\end{array}$ & $\begin{array}{r}517 \\
1,040\end{array}$ & $\begin{array}{l}1,030 \\
1,790\end{array}$ & $\begin{array}{l}1,610 \\
2,530\end{array}$ & $\begin{array}{l}2,390 \\
3,460\end{array}$ & $\begin{array}{l}3,430 \\
4,590\end{array}$ & $\begin{array}{l}5,310 \\
6,450\end{array}$ & $\begin{array}{l}\text { LP3W } 84 \\
\text {-East- }\end{array}$ & $1951-78$ & 1959 & 5,000 \\
\hline & 8044 & 06804400 & $\begin{array}{l}\text { Silver Cr trib at Colon, Nebr. } \\
(-0.055 \text {-Skew map, SE }-0.080 \text {-East })\end{array}$ & PS & $\begin{array}{l}102 \\
316\end{array}$ & $\begin{array}{l}386 \\
921\end{array}$ & $\begin{array}{r}766 \\
1,550\end{array}$ & $\begin{array}{l}1,580 \\
2,620\end{array}$ & $\begin{array}{l}2,500 \\
3,670\end{array}$ & $\begin{array}{l}3,780 \\
4,950\end{array}$ & $\begin{array}{l}5,500 \\
6,510\end{array}$ & $\begin{array}{l}8,640 \\
9,040\end{array}$ & $\begin{array}{l}\text { LP3W } 84 \\
\text {-East- }\end{array}$ & $1951-78$ & 1959 & 4,640 \\
\hline & 8045 & 06804500 & $\begin{array}{l}\text { Silver Cr at Ithaca, Nebr. } \\
(-0.100 \text {-Skew map, SE }-0.111 \text {-East })\end{array}$ & PS & $\begin{array}{r}643 \\
1,250\end{array}$ & $\begin{array}{l}2,590 \\
3,190\end{array}$ & $\begin{array}{l}5,220 \\
5,000\end{array}$ & $\begin{array}{r}10,800 \\
7,880\end{array}$ & $\begin{array}{l}17,100 \\
10,500\end{array}$ & $\begin{array}{l}25,800 \\
13,500\end{array}$ & $\begin{array}{l}37,200 \\
16,900\end{array}$ & $\begin{array}{l}57,600 \\
22,200\end{array}$ & $\begin{array}{c}\text { LP3W } 84 \\
\text {-East- }\end{array}$ & $1950-78$ & 1959 & 21,600 \\
\hline & 8050 & 06805000 & 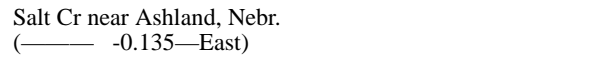 & CR & $\begin{array}{r}17,900 \\
5,990\end{array}$ & $\begin{array}{l}32,000 \\
14,200\end{array}$ & $\begin{array}{l}41,700 \\
21,600\end{array}$ & $\begin{array}{l}54,000 \\
32,900\end{array}$ & $\begin{array}{l}63,000 \\
42,900\end{array}$ & $\begin{array}{l}71,600 \\
54,200\end{array}$ & $\begin{array}{l}80,000 \\
67,100\end{array}$ & $\begin{array}{l}90,600 \\
86,400\end{array}$ & $\begin{array}{l}\text { LP3W } 21 \\
\text {-East- }\end{array}$ & $1947-67$ & 1963 & 87,000 \\
\hline & 8055 & 06805500 & $\begin{array}{l}\text { Platte } \mathrm{R} \text { at Louisville, Nebr. } \\
\quad\left(85,800 \mathrm{mi}^{2} \text {, approximately, of which about } 71,000 \mathrm{mi}^{2} \mathrm{cc}\right.\end{array}$ & $\begin{array}{l}\mathrm{CR} \\
\text { ributes }\end{array}$ & $\begin{array}{l}46,600 \\
\text { directly to }\end{array}$ & $\begin{array}{l}76,700 \\
\text { surface } r\end{array}$ & $\begin{array}{l}98,400 \\
\text { unoff-frol }\end{array}$ & $\begin{array}{l}127,000 \\
\text { m Boohar }\end{array}$ & $\begin{array}{l}150,000 \\
\text { and others }\end{array}$ & $\begin{array}{l}173,000 \\
, 1992)\end{array}$ & 197,000 & 229,000 & REG 41 & 1953-93 & 1993 & 160,000 \\
\hline & $8055 \mathrm{~b}$ & 06805510 & $\begin{array}{l}\text { Buffalo Cr near Gretna, Nebr. } \\
(--0.183-\text { New station for East network analysis) }\end{array}$ & PS & 325 & $\begin{array}{l}\text { Inst } \\
743\end{array}$ & $\begin{array}{l}\text { ufficient da } \\
1,130\end{array}$ & $\begin{array}{l}\text { ata-flows } \\
1,770\end{array}$ & $\begin{array}{l}\text { unknown } \\
2,370\end{array}$ & $\begin{array}{r}\text { for all } 11 \\
3,080\end{array}$ & $\begin{array}{l}\text { eaks } \\
3,910\end{array}$ & 5,200 & -East- & $1968-78$ & --- & --- \\
\hline & 8060 & 06806000 & $\begin{array}{l}\text { Waubonsie Cr near Bartlett, Iowa } \\
(-0.023 \text {-Skew map } \longrightarrow\end{array}$ & $\mathrm{CR}$ & & & f-state st & $\begin{array}{l}\text { tation used } \\
\text { No basin ch }\end{array}$ & $\begin{array}{l}\text { only for } \\
\text { aracterist }\end{array}$ & $\begin{array}{l}\text { kew re } \\
\text { cs }\end{array}$ & & & & $1946-69$ & 1950 & 14,500 \\
\hline
\end{tabular}


Table B2. Peak-flow frequency data for streamflow-gaging stations in Nebraska and for selected out-of-state stations,

and drainage areas for regulated streams--Continued

\begin{tabular}{|c|c|c|c|c|c|c|c|c|c|c|c|c|c|c|c|}
\hline \multirow{3}{*}{$\begin{array}{c}\begin{array}{c}\text { Map } \\
\text { num- } \\
\text { ber }\end{array} \\
8064\end{array}$} & \multirow{3}{*}{$\begin{array}{c}\begin{array}{c}\text { Station } \\
\text { number }\end{array} \\
06806400\end{array}$} & \multirow{3}{*}{$\begin{array}{l}\begin{array}{c}\text { Station name } \\
\text { (station skew_skew relations generalized } \\
\text { skew-peak-flow regional equations or remarks) }\end{array} \\
\text { Weeping Water Cr at Elmwood, Nebr. } \\
(--0.275 \text {-East) }\end{array}$} & \multirow{3}{*}{$\begin{array}{c}\begin{array}{c}\text { Gage } \\
\text { type }\end{array} \\
\text { PS }\end{array}$} & \multicolumn{8}{|c|}{$\begin{array}{l}\text { Peak discharge }\left(\mathrm{ft}^{3} / \mathrm{s}\right) \text { for given recurrence interval (years) } \\
\text { and/or remarks }\end{array}$} & \multirow{3}{*}{$\begin{array}{c}\text { Type and length } \\
\text { (years) of analysis } \\
\text {-regional } \\
\text { equation- }\end{array}$} & \multirow{3}{*}{$\begin{array}{c}\begin{array}{c}\text { Period of } \\
\text { peak-flow } \\
\text { record }\end{array} \\
1950-67\end{array}$} & \multirow{2}{*}{\multicolumn{2}{|c|}{$\begin{array}{c}\text { WY and dis- } \\
\text { charge e }\left(\mathrm{ft}^{\mathrm{t}} / \mathrm{s}\right) \\
\text { of maximum } \\
\text { peak }\end{array}$}} \\
\hline & & & & 2 & 5 & 10 & 25 & 50 & 100 & 200 & 500 & & & & \\
\hline & & & & $\begin{array}{l}1,830 \\
1,270\end{array}$ & $\begin{array}{l}4,640 \\
3,050\end{array}$ & $\begin{array}{l}7,310 \\
4,600\end{array}$ & $\begin{array}{r}11,600 \\
6,930\end{array}$ & $\begin{array}{r}15,400 \\
8,940\end{array}$ & $\begin{array}{l}19,800 \\
11,200\end{array}$ & $\begin{array}{l}24,600 \\
13,600\end{array}$ & $\begin{array}{l}31,900 \\
17,200\end{array}$ & & & 1951 & 6,390 \\
\hline $8064 \mathrm{~b}$ & 06806420 & $\begin{array}{l}\text { Stove Cr near Elmwood, Nebr. } \\
\left(\square^{-0.317-E a s t)}\right.\end{array}$ & PS & $\begin{array}{r}1,210 \\
509\end{array}$ & $\begin{array}{l}2,260 \\
1,350\end{array}$ & $\begin{array}{l}3,070 \\
2,140\end{array}$ & $\begin{array}{l}4,180 \\
3,380\end{array}$ & $\begin{array}{l}5,060 \\
4,480\end{array}$ & $\begin{array}{l}5,980 \\
5,740\end{array}$ & $\begin{array}{l}6,920 \\
7,160\end{array}$ & $\begin{array}{l}8,220 \\
9,310\end{array}$ & $\begin{array}{l}\text { LP3W } 22 \\
\text {-East- }\end{array}$ & $\begin{array}{l}\text { 1950-67, } \\
1971\end{array}$ & 1956 & 3,430 \\
\hline $8064 \mathrm{c}$ & 06806440 & $\begin{array}{l}\text { Stove Cr at Elmwood, Nebr. } \\
(-0.398 \text {-Skew map, SE -0.323-East })\end{array}$ & PS & $\begin{array}{r}1,310 \\
885\end{array}$ & $\begin{array}{l}3,230 \\
2,210\end{array}$ & $\begin{array}{l}4,990 \\
3,390\end{array}$ & $\begin{array}{l}7,750 \\
5,190\end{array}$ & $\begin{array}{r}10,100 \\
6,740\end{array}$ & $\begin{array}{r}12,800 \\
8,480\end{array}$ & $\begin{array}{l}15,800 \\
10,400\end{array}$ & $\begin{array}{l}20,000 \\
13,200\end{array}$ & $\begin{array}{l}\text { LP3W } 29 \\
\text {-East- }\end{array}$ & 1950-78 & 1950 & 9,500 \\
\hline $8064 d$ & 06806460 & $\begin{array}{l}\text { Weeping Water } \mathrm{Cr} \text { at Weeping Water, Nebr. } \\
(-0.575 \text { - Skew map, SE }-0.286 \text {-East })\end{array}$ & PS & $\begin{array}{l}2,360 \\
2,930\end{array}$ & $\begin{array}{l}6,010 \\
6,460\end{array}$ & $\begin{array}{l}9,450 \\
9,380\end{array}$ & $\begin{array}{l}14,900 \\
13,700\end{array}$ & $\begin{array}{l}19,700 \\
17,200\end{array}$ & $\begin{array}{l}25,200 \\
21,100\end{array}$ & $\begin{array}{l}31,200 \\
25,300\end{array}$ & $\begin{array}{l}40,100 \\
31,400\end{array}$ & $\begin{array}{l}\text { LP3W } 96 \\
\text {-East- }\end{array}$ & $\begin{array}{c}1947 \\
1950-78\end{array}$ & 1950 & 30,300 \\
\hline $8064 \mathrm{e}$ & 06806470 & $\begin{array}{l}\text { Weeping Water Cr trib near Weeping Water, Nebr. } \\
(-0.303-\text { Skew map } \longrightarrow)\end{array}$ & PS & 281 & ${ }^{622} T L$ & $\begin{array}{c}924 \\
<1 \mathrm{mi}^{2}\end{array}$ & $\begin{array}{l}1,390 \\
\text { Basin ch }\end{array}$ & $\begin{array}{l}1,790 \\
\text { aracteristic }\end{array}$ & $\begin{array}{l}2,240 \\
\text { incomple }\end{array}$ & 2,740 & 3,470 & LP3W 29 & 1950-78 & 1967 & 1,570 \\
\hline 8065 & 06806500 & $\begin{array}{l}\text { Weeping Water } \mathrm{Cr} \text { at Union, Nebr. } \\
(-0.377 \text {-Skew map, SE } \quad-0.367 \text {-East })\end{array}$ & $\mathrm{CR}$ & $\begin{array}{l}5,660 \\
6,320\end{array}$ & $\begin{array}{l}15,500 \\
13,200\end{array}$ & $\begin{array}{l}25,100 \\
18,600\end{array}$ & $\begin{array}{l}40,700 \\
26,200\end{array}$ & $\begin{array}{l}54,800 \\
32,300\end{array}$ & $\begin{array}{l}70,700 \\
38,680\end{array}$ & $\begin{array}{l}88,500 \\
45,600\end{array}$ & $\begin{array}{r}115,000 \\
55,100\end{array}$ & $\begin{array}{l}\text { LP3W } 44 \\
\text {-East- }\end{array}$ & 1950-93 & 1993 & 65,100 \\
\hline $8077 \mathrm{a}$ & 06807720 & $\begin{array}{l}\text { Middle Silver Cr near Avoca, Iowa, } \\
(-0.254 \text {-Skew map }-)\end{array}$ & PS & & Out & of-state st & ation used & only for s. & kew relatio & $\mathrm{n}(\mathrm{s})$ & & & $\begin{array}{l}1953-84 \\
1986\end{array}$ & 1976 & 1,200 \\
\hline $8077 \mathrm{~b}$ & 06807760 & $\begin{array}{l}\text { Middle Silver Cr near Oakland, Iowa } \\
(+0.030 \text {-Skew map } \longrightarrow)\end{array}$ & PS & & Out & of-state st & ation used & only for s. & kew relatio & $\mathrm{n}(\mathrm{s})$ & & & 1953-90 & 1973 & 2,110 \\
\hline $8077 \mathrm{c}$ & 06807780 & $\begin{array}{l}\text { Middle Silver } \mathrm{Cr} \text { at Treynor, Iowa } \\
(+0.314-\text { Skew map }-)\end{array}$ & PS & & Out & of-state st & ation used & only for s & kew relatio & $n(s)$ & & & 1953-90 & 1973 & 3,700 \\
\hline 8085 & 06808500 & $\begin{array}{l}\text { W Nishnabotna R at Randolph, Iowa } \\
(-0.617-\text { Skew map }\end{array}$ & CR & & & of-state & $\begin{array}{l}\text { ion used } \\
\text { basin ch }\end{array}$ & $\begin{array}{l}\text { only for } \\
\text { aracteris }\end{array}$ & relatio & & & & 1949-93 & 1987 & 40,800 \\
\hline 8100 & 06810000 & $\begin{array}{l}\text { Nishnabotna } R \text { above Hamburg, Iowa } \\
(-0.244-\text { Skew map } \longrightarrow)\end{array}$ & $\mathrm{CR}$ & & & of-state st & $\begin{array}{ll}\text { on use } \\
\text { asin }\end{array}$ & $\mathrm{y} \mathrm{fo}$ & relatio & & & & $\begin{array}{l}1922-23, \\
1929-93\end{array}$ & 1947 & 55,500 \\
\hline $8100 \mathrm{~b}$ & 06810060 & 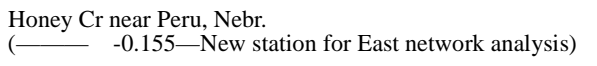 & PS & $\begin{array}{l}529 \\
256\end{array}$ & $\begin{array}{r}1,190 \\
599\end{array}$ & $\begin{array}{r}1,800 \\
923\end{array}$ & $\begin{array}{l}2,760 \\
1,470\end{array}$ & $\begin{array}{l}3,620 \\
1,990\end{array}$ & $\begin{array}{l}4,610 \\
2,600\end{array}$ & $\begin{array}{l}5,730 \\
3,230\end{array}$ & $\begin{array}{l}7,420 \\
4,470\end{array}$ & $\begin{array}{l}\text { LP3W } 11 \\
\text {-East- }\end{array}$ & 1968-78 & 1973 & 3,200 \\
\hline 8101 & 06810100 & $\begin{array}{l}\text { Hooper Cr trib near Palmyra, Nebr. } \\
(-0.064 \text {-Skew map, SE }-0.323 \text {-East })\end{array}$ & PS & $\begin{array}{l}710 \\
806\end{array}$ & $\begin{array}{l}1,710 \\
1,950\end{array}$ & $\begin{array}{l}2,610 \\
2,970\end{array}$ & $\begin{array}{l}4,000 \\
4,500\end{array}$ & $\begin{array}{l}5,200 \\
5,840\end{array}$ & $\begin{array}{l}6,520 \\
7,330\end{array}$ & $\begin{array}{l}7,970 \\
8,980\end{array}$ & $\begin{array}{l}10,060 \\
11,400\end{array}$ & $\begin{array}{l}\text { LP3W } 29 \\
\text {-East- }\end{array}$ & 1950-78 & 1963 & 4,210 \\
\hline 8102 & 06810200 & $\begin{array}{l}\text { Hooper Cr near Palmyra, Nebr. } \\
\left({ }^{-}-0.438 \text {-East }\right)\end{array}$ & PS & $\begin{array}{l}3,400 \\
2,930\end{array}$ & $\begin{array}{l}6,980 \\
6,720\end{array}$ & $\begin{array}{l}9,860 \\
9,860\end{array}$ & $\begin{array}{l}13,900 \\
14,400\end{array}$ & $\begin{array}{l}17,200 \\
18,100\end{array}$ & $\begin{array}{l}20,600 \\
22,000\end{array}$ & $\begin{array}{l}24,100 \\
26,300\end{array}$ & $\begin{array}{l}29,000 \\
32,200\end{array}$ & $\begin{array}{l}\text { LP3W } 18 \\
\text {-East- }\end{array}$ & 1950-67 & 1950 & 47,600 \\
\hline 8103 & 06810300 & $\begin{array}{l}\text { Wolf Cr near Syracuse, Nebr. } \\
(\longleftarrow-0.469 \text {-East })\end{array}$ & PS & $\begin{array}{l}1,900 \\
1,908\end{array}$ & $\begin{array}{l}4,980 \\
4,360\end{array}$ & $\begin{array}{l}7,850 \\
6,420\end{array}$ & $\begin{array}{r}12,300 \\
9,400\end{array}$ & $\begin{array}{l}16,200 \\
11,900\end{array}$ & $\begin{array}{l}20,400 \\
14,600\end{array}$ & $\begin{array}{l}25,000 \\
17,500\end{array}$ & $\begin{array}{l}31,500 \\
21,600\end{array}$ & $\begin{array}{l}\text { LP3W } 18 \\
\text {-East- }\end{array}$ & 1950-67 & 1950 & 16,000 \\
\hline 8104 & 06810400 & $\begin{array}{l}\text { Little Nemaha R trib near Syracuse, Nebr. } \\
(-0.406 \text {-Skew map }\end{array}$ & PS & 199 & 420 & & $\begin{array}{l}890 \\
\text { o basin ch }\end{array}$ & $\begin{array}{l}1,130 \\
\text { aracteristi }\end{array}$ & 1,390 & 1,670 & 2,080 & LP3W 29 & 1950-78 & 1950 & 1,280 \\
\hline 8105 & 06810500 & $\begin{array}{l}\text { Little Nemaha R near Syracuse, Nebr. } \\
(-0.182 \text {-Skew map }-0.457 \text {-East })\end{array}$ & CR & $\begin{array}{l}7,300 \\
6,020\end{array}$ & $\begin{array}{l}14,400 \\
13,200\end{array}$ & $\begin{array}{l}20,200 \\
18,900\end{array}$ & $\begin{array}{l}28,600 \\
26,900\end{array}$ & $\begin{array}{l}35,400 \\
33,400\end{array}$ & $\begin{array}{l}42,700 \\
40,200\end{array}$ & $\begin{array}{l}50,500 \\
47,300\end{array}$ & $\begin{array}{l}61,500 \\
57,100\end{array}$ & $\begin{array}{l}\text { LP3W } 140 \\
\text {-East- }\end{array}$ & 1950-69 & 1950 & 225,000 \\
\hline 8115 & 06811500 & $\begin{array}{l}\text { Little Nemaha R at Auburn, Nebr. } \\
(-0.374 \text {-Skew map, SE }-0.479 \text {-East })\end{array}$ & CR & $\begin{array}{l}15,800 \\
14,100\end{array}$ & $\begin{array}{l}37,900 \\
29,000\end{array}$ & $\begin{array}{l}56,800 \\
40,300\end{array}$ & $\begin{array}{l}84,400 \\
55,500\end{array}$ & $\begin{array}{c}107,000 \\
67,300\end{array}$ & $\begin{array}{r}130,000 \\
79,400\end{array}$ & $\begin{array}{c}154,000 \\
91,700\end{array}$ & $\begin{array}{l}188,000 \\
108,000\end{array}$ & $\begin{array}{l}\text { LP3W } 140 \\
\text { East- }\end{array}$ & 1950-93 & 1950 & 164,000 \\
\hline
\end{tabular}


Table B2. Peak-flow frequency data for streamflow-gaging stations in Nebraska and for selected out-of-state stations,

and drainage areas for regulated streams--Continued

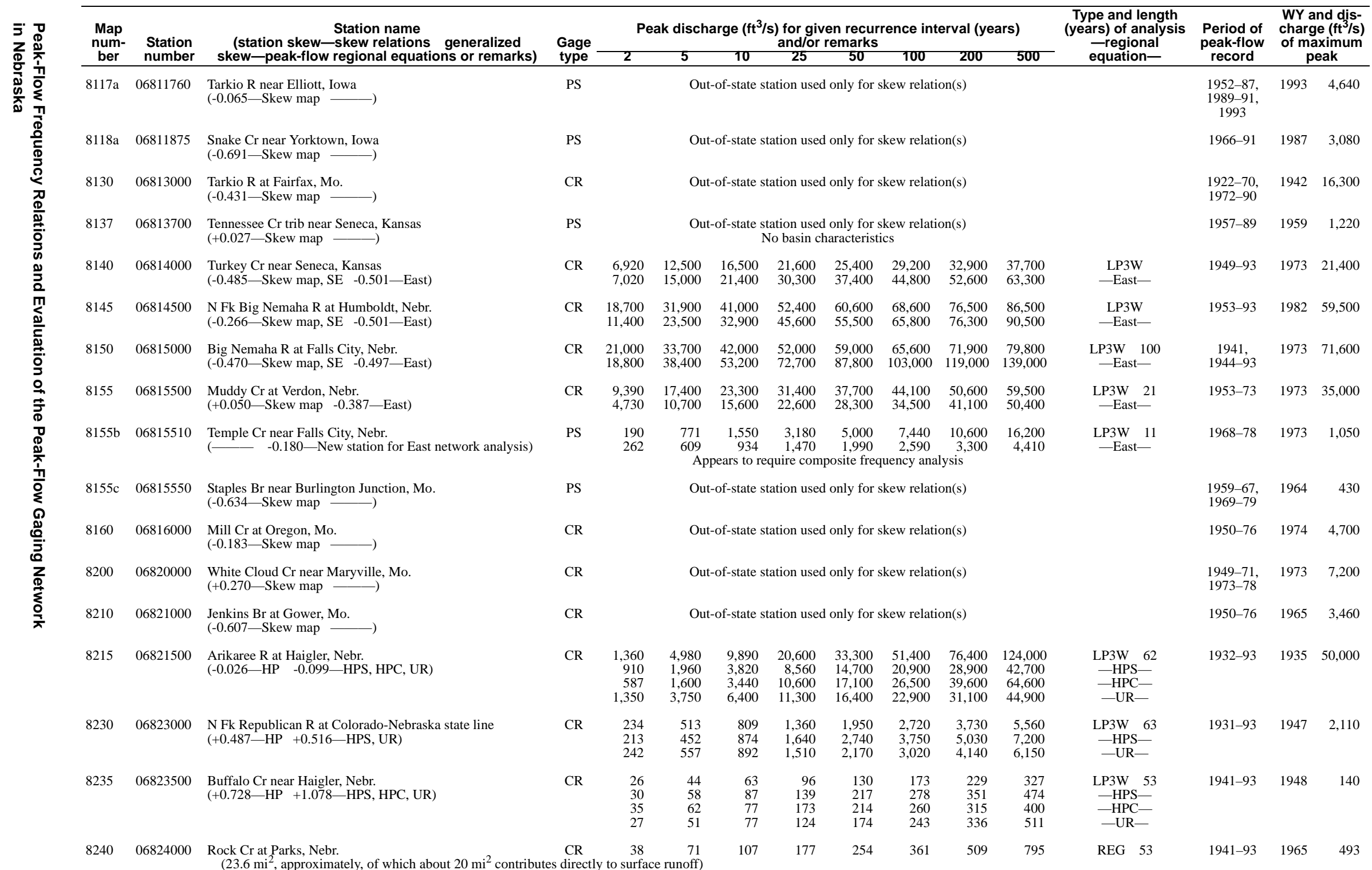


Table B2. Peak-flow frequency data for streamflow-gaging stations in Nebraska and for selected out-of-state stations,

and drainage areas for regulated streams--Continued

\begin{tabular}{|c|c|c|c|c|c|c|c|c|c|c|c|c|c|c|c|}
\hline \multirow{3}{*}{$\begin{array}{c}\begin{array}{c}\text { Map } \\
\text { num- } \\
\text { ber }\end{array} \\
8245\end{array}$} & \multirow{3}{*}{$\begin{array}{c}\begin{array}{c}\text { Station } \\
\text { number }\end{array} \\
06824500\end{array}$} & \multirow{3}{*}{$\begin{array}{c}\begin{array}{c}\text { Station name } \\
\text { (station skew-skew relations }\end{array} \\
\text { skew-peak-flow regional equations or remarks) }\end{array}$} & \multirow{3}{*}{$\begin{array}{c}\text { Gage } \\
\text { type } \\
\mathrm{CR}\end{array}$} & \multirow{2}{*}{\multicolumn{8}{|c|}{$\begin{array}{l}\text { Peak discharge }\left(\mathrm{ft}^{3} / \mathrm{s}\right) \text { for given recurrence interval (years) } \\
\text { and/or remarks }\end{array}$}} & \multirow{3}{*}{$\begin{array}{c}\begin{array}{c}\text { Type and length } \\
\text { (years) of analysis } \\
\text { - regional } \\
\text { equation- }\end{array} \\
\begin{array}{c}\text { LP3W } 167 \\
\text { - HPS- } \\
\text {-UR- }\end{array}\end{array}$} & \multirow{3}{*}{$\begin{array}{c}\begin{array}{c}\text { Period of } \\
\text { peak-flow } \\
\text { record }\end{array} \\
1895 \\
1902-06 \\
1947-93\end{array}$} & \multirow{2}{*}{\multicolumn{2}{|c|}{$\begin{array}{l}\text { WY and dis- } \\
\text { charge }\left(\mathrm{ft}^{3} / \mathrm{s}\right) \\
\text { of maximum } \\
\text { peak }\end{array}$}} \\
\hline & & & & & & & & & & & & & & & \\
\hline & & & & $\begin{array}{r}1,090 \\
975 \\
1,140\end{array}$ & $\begin{array}{l}2,870 \\
2,190 \\
3,000\end{array}$ & $\begin{array}{l}4,850 \\
3,940 \\
5,060\end{array}$ & $\begin{array}{l}8,630 \\
8,830 \\
8,950\end{array}$ & $\begin{array}{l}12,600 \\
15,600 \\
13,000\end{array}$ & $\begin{array}{l}17,900 \\
21,600 \\
18,300\end{array}$ & $\begin{array}{l}24,800 \\
29,300 \\
25,100\end{array}$ & $\begin{array}{l}36,900 \\
42,300 \\
37,000\end{array}$ & & & 1935 & 50,000 \\
\hline 8250 & 06825000 & $\begin{array}{l}\text { S Fk Republican R near Idalia, Colo. } \\
\left({ }_{-}^{-0.523} \text {-UR) }\right.\end{array}$ & CR & $\begin{array}{l}3,580 \\
2,770\end{array}$ & $\begin{array}{l}8,270 \\
8,620\end{array}$ & $\begin{array}{l}12,100 \\
15,200\end{array}$ & $\begin{array}{l}17,300 \\
27,400\end{array}$ & $\begin{array}{l}21,400 \\
39,500\end{array}$ & $\begin{array}{l}25,500 \\
54,400\end{array}$ & $\begin{array}{l}29,600 \\
72,400\end{array}$ & $\begin{array}{r}34,900 \\
101,000\end{array}$ & $\begin{array}{l}\mathrm{LP} 3 \mathrm{~W} \\
-\mathrm{UR}-\end{array}$ & $\begin{array}{c}1935 \\
1951-75\end{array}$ & 1935 & 103,000 \\
\hline 8255 & 06825500 & $\begin{array}{l}\text { Landsman Cr near Hale, Colo. } \\
(-0.096 \text {-Skew map }-0.090-U R)\end{array}$ & CR & $\begin{array}{r}1,380 \\
762\end{array}$ & $\begin{array}{l}3,510 \\
2,130\end{array}$ & $\begin{array}{l}5,660 \\
3,600\end{array}$ & $\begin{array}{l}9,350 \\
6,260\end{array}$ & $\begin{array}{r}12,900 \\
8,900\end{array}$ & $\begin{array}{l}17,100 \\
12,200\end{array}$ & $\begin{array}{l}22,200 \\
16,200\end{array}$ & $\begin{array}{l}30,300 \\
22,800\end{array}$ & $\begin{array}{l}\mathrm{LP} 3 \mathrm{~W} \\
\text {-UR- }\end{array}$ & 1951-76 & 1975 & 13,000 \\
\hline 8275 & 06827500 & $\begin{array}{l}\text { S Fk Republican R near Benkelman, Nebr. } \\
\left(2,630 \mathrm{mi}^{2} \text {, approximately, of which about } 2,100 \mathrm{mi}^{2} \text { contri }\right.\end{array}$ & $\begin{array}{l}\mathrm{CR} \\
\text { butes dire }\end{array}$ & $\begin{array}{l}1,310 \\
\text { ectly to su }\end{array}$ & $\begin{array}{l}4,380 \\
\text { Irface runo }\end{array}$ & fff) 7,930 & 14,500 & 21,100 & 29,400 & 39,300 & 55,500 & REG 44 & $\begin{array}{l}\text { 1903-06, } \\
1931-32 \\
1938-93\end{array}$ & 1958 & 19,600 \\
\hline 8280 & 06828000 & $\begin{array}{l}\text { Republican R at Max, Nebr. } \\
(-+0.002-\text { HPS, UR })\end{array}$ & $\mathrm{CR}$ & $\begin{array}{l}4,800 \\
3,030 \\
3,120\end{array}$ & $\begin{array}{r}11,400 \\
6,730 \\
9,200\end{array}$ & $\begin{array}{l}17,900 \\
12,200 \\
16,000\end{array}$ & $\begin{array}{l}29,000 \\
27,100 \\
28,800\end{array}$ & $\begin{array}{l}39,600 \\
45,600 \\
41,900\end{array}$ & $\begin{array}{l}52,400 \\
63,900 \\
58,400\end{array}$ & $\begin{array}{l}67,900 \\
86,900 \\
78,800\end{array}$ & $\begin{array}{r}92,800 \\
126,000 \\
113,000\end{array}$ & $\begin{array}{l}\text { LP3W } 120 \\
\text {-HPS- } \\
\text {-UR- }\end{array}$ & $\begin{array}{l}1929-35 \\
1937-46\end{array}$ & 1935 & 190,000 \\
\hline 8281 & 06828100 & $\begin{array}{l}\mathrm{N} \text { Br Indian Cr near Max, Nebr. } \\
(-\quad-0.090-\text { New station for UR network analysis })\end{array}$ & PS & 299 & $\begin{array}{l}582 \\
\text { Basin }\end{array}$ & $\begin{array}{c}824 \\
\text { character }\end{array}$ & $\begin{array}{l}1,200 \\
\text { stic(s) out }\end{array}$ & $\begin{array}{l}1,520 \\
\text { tside of ran }\end{array}$ & $\begin{array}{l}1,890 \\
\text { tge for equ }\end{array}$ & $\begin{array}{l}2,300 \\
\text { lations }\end{array}$ & 2,920 & $\begin{array}{l}\text { LP3W } 9 \\
-\mathrm{UR}-\end{array}$ & $\begin{array}{c}1962, \\
1970-78\end{array}$ & 1962 & 12,900 \\
\hline 8285 & 06828500 & $\begin{array}{l}\text { Republican } \mathrm{R} \text { at Stratton, Nebr. } \\
\left(8,200 \mathrm{mi}^{2} \text {, approximately, of which about } 3,690 \mathrm{mi}^{2} \text { contri }\right.\end{array}$ & $\begin{array}{ll}\mathrm{CR} \\
\text { butes dire }\end{array}$ & $\begin{array}{l}2,480 \\
\text { ectly to su }\end{array}$ & $\begin{array}{l}5,640 \\
\text { ace runo }\end{array}$ & ${ }_{\mathrm{fff})}^{8,920}$ & 14,900 & 20,900 & 28,700 & 38,700 & 55,900 & REG 44 & 1950-93 & 1962 & 26,800 \\
\hline 8295 & 06829500 & $\begin{array}{l}\text { Republican } \mathrm{R} \text { at Trenton, Nebr. } \\
\left(8,620 \mathrm{mi}^{2} \text {, approximately, of which about } 3,940 \mathrm{mi}^{2} \text { contri }\right.\end{array}$ & $\begin{array}{c}\mathrm{CR} \\
\text { butes dire }\end{array}$ & $\begin{array}{l}366 \\
\text { ctly to su }\end{array}$ & $\begin{array}{l}791 \\
\text { ace runo }\end{array}$ & 1,290 & 2,330 & 3,560 & 5,340 & 7,920 & 13,100 & REG 40 & $\begin{array}{c}1935, \\
1946-93\end{array}$ & 1935 & 200,000 \\
\hline 8297 & 06829700 & $\begin{array}{l}\text { Thompson Canyon near Trenton, Nebr. } \\
(\longleftarrow-0.090-\text { New station for UR network analysis })\end{array}$ & PS & 289 & $\begin{array}{l}701 \\
\text { Basin }\end{array}$ & $\begin{array}{l}1,110 \\
\text { characteri }\end{array}$ & $\begin{array}{l}1,810 \\
\text { stic(s) out }\end{array}$ & $\begin{array}{l}2,470 \\
\text { tside of ran }\end{array}$ & $\begin{array}{l}3,270 \\
\text { tge for equ }\end{array}$ & $\begin{array}{l}4,230 \\
\text { rations }\end{array}$ & 5,760 & $\begin{array}{l}\mathrm{LP} 3 \mathrm{~W} \\
-\mathrm{UR}-\end{array}$ & 1966-78 & 1977 & 1,800 \\
\hline 8310 & 06831000 & $\begin{array}{l}\text { Frenchman } \mathrm{Cr} \text { below Champion, Nebr. } \\
\text { ( } 519 \mathrm{mi}^{2} \text {, approximately, of which about } 421 \mathrm{mi}^{2} \text { contribute } \\
\text { to (total) drainage area in Boohar and others (1995); a revis }\end{array}$ & $\begin{array}{l}\text { CR } \\
\text { e directly }\end{array}$ & $\begin{array}{l}388 \\
\text { to surface }\end{array}$ & $\begin{array}{l}878 \\
\text { Inoff. } \mathrm{H}\end{array}$ & $\begin{array}{l}1,370 \\
\text { Iowever, th }\end{array}$ & $\begin{array}{l}2,220 \\
\text { se values }\end{array}$ & $\begin{array}{l}3,060 \\
\text { do not ref }\end{array}$ & $\begin{array}{l}4,110 \\
\text { flect latest }\end{array}$ & $\begin{array}{l}5,400 \\
\text { revision o }\end{array}$ & $\begin{aligned} & 7,560 \\
& \text { of } 721 \mathrm{mi}^{2}\end{aligned}$ & REG 22 & $1935-56$ & 1940 & 2,850 \\
\hline 8315 & 06831500 & $\begin{array}{l}\text { Frenchman Cr near Imperial, Nebr. } \\
\quad\left(1,050 \mathrm{mi}^{2} \text {, of which } 859 \mathrm{mi}^{2} \text { contributes directly to surface }\right.\end{array}$ & $\begin{array}{l}\mathrm{CR} \\
\text { runoff) }\end{array}$ & 160 & 387 & 668 & 1,280 & 2,820 & 3,120 & 4,750 & 8,150 & REG 53 & 1941-93 & 1960 & 2,340 \\
\hline 8325 & 06832500 & $\begin{array}{l}\text { Frenchman Cr near Enders, Nebr. } \\
\quad\left(930 \mathrm{mi}^{2} \text { approximately, of which about } 790 \mathrm{mi}^{2} \text { contribb }\right. \\
1,140 \mathrm{mi}^{2} \text { to (total) drainage area in Boohar and others }(1\end{array}$ & $\begin{array}{l}\mathrm{CR} \\
\text { es directly } \\
\text { 5); a revi }\end{array}$ & $\begin{array}{l}352 \\
\text { to surfa } \\
\text { sed valu }\end{array}$ & $\begin{array}{l}460 \\
\text { runoff. } \\
\text { f contrib }\end{array}$ & $\begin{array}{c}524 \\
\text { However, th } \\
\text { buting drain }\end{array}$ & $\begin{array}{c}599 \\
\text { hese value } \\
\text { lage area }\end{array}$ & $\begin{array}{c}650 \\
\text { do not re } \\
\text { as not pu }\end{array}$ & $\begin{array}{c}699 \\
\text { eflect latest } \\
\text { bllished.) }\end{array}$ & $\begin{array}{l}745 \\
\text { t revision }\end{array}$ & 804 & REG 43 & 1946-93 & 1953 & 763 \\
\hline 8340 & 06834000 & $\begin{array}{l}\text { Frenchman } \mathrm{Cr} \text { at Palisade, Nebr. } \\
\qquad\left(1,300 \mathrm{mi}^{2} \text {, approximately, of which about } 1,110 \mathrm{mi}^{2} \text { contri }\right.\end{array}$ & $\begin{array}{l}\mathrm{CR} \\
\text { butes dire }\end{array}$ & $\begin{array}{l}604 \\
\text { ctly to st }\end{array}$ & $\begin{array}{l}1,080 \\
\text { ace runof }\end{array}$ & ff) 1,540 & 2,320 & 3,090 & 4,060 & 5,260 & 7,310 & REG 43 & $\begin{array}{l}\text { 1895-96, } \\
\text { 1951-93 }\end{array}$ & 1956 & 5,560 \\
\hline 8345 & 06834500 & $\begin{array}{l}\text { Stinking Water Cr near Wauneta, Nebr. } \\
(\longrightarrow)\end{array}$ & CR & & $\begin{array}{c}516 \\
\text { ontributi }\end{array}$ & $\begin{array}{c}729 \\
\text { Ig draina }\end{array}$ & $\begin{array}{l}1,050 \\
\text { area kn }\end{array}$ & $\begin{array}{l}1,330 \\
\text { wn to exi }\end{array}$ & $\begin{array}{l}1,640 \\
\text { ist, but amo }\end{array}$ & $\begin{array}{l}1,990 \\
\text { ount unkno }\end{array}$ & $\begin{array}{l}2,510 \\
\text { lown }\end{array}$ & LP3W 10 & 1941-50 & 1949 & 626 \\
\hline 8350 & 06835000 & $\begin{array}{l}\text { Stinking Water Cr near Palisade, Nebr. } \\
(+0.353-\mathrm{HP}+0.359-\mathrm{HPS}, \mathrm{HPC}, \mathrm{UR})\end{array}$ & CR & $\begin{array}{l}271 \\
581 \\
457 \\
334\end{array}$ & $\begin{array}{r}648 \\
1,240 \\
1,090 \\
798\end{array}$ & $\begin{array}{l}1,060 \\
2,400 \\
2,270 \\
1,280\end{array}$ & $\begin{array}{l}1,830 \\
4,560 \\
5,180 \\
2,160\end{array}$ & $\begin{array}{l}2,650 \\
7,560 \\
7,820 \\
3,060\end{array}$ & $\begin{array}{r}3,730 \\
10,400 \\
11,400 \\
4,210\end{array}$ & $\begin{array}{r}5,150 \\
13,900 \\
16,100 \\
5,670\end{array}$ & $\begin{array}{r}7,680 \\
20,000 \\
24,600 \\
8,190\end{array}$ & $\begin{array}{l}\text { LP3W } 44 \\
\text {-HPS- } \\
\text {-HPC- } \\
\text {-UR- }\end{array}$ & 1950-93 & 1956 & 3,030 \\
\hline 8351 & 06835100 & $\begin{array}{l}\text { Bobtail Cr near Palisade, Nebr. } \\
(-\quad-0.100-\text { New station for UR network analysis })\end{array}$ & CR & $\begin{array}{l}416 \\
512\end{array}$ & $\begin{array}{l}1,550 \\
1,520\end{array}$ & $\begin{array}{l}3,080 \\
2,650\end{array}$ & $\begin{array}{l}6,410 \\
4,680\end{array}$ & $\begin{array}{r}10,300 \\
6,600\end{array}$ & $\begin{array}{r}15,800 \\
9,070\end{array}$ & $\begin{array}{l}23,400 \\
11,800\end{array}$ & $\begin{array}{l}37,600 \\
16,600\end{array}$ & $\begin{array}{l}\mathrm{LP} 3 \mathrm{~W} \\
\text {-UR- }\end{array}$ & 1966-78 & 1972 & 15,200 \\
\hline 8355 & 06835500 & $\begin{array}{l}\text { Frenchman } \mathrm{Cr} \text { at Culbertson, Nebr. } \\
\left(2,990 \mathrm{mi}^{2} \text {, approximately, of which about } 1,590 \mathrm{mi}^{2} \text { cont }\right.\end{array}$ & $\begin{array}{l}\mathrm{CR} \\
\text { ites di }\end{array}$ & 741 & $\begin{array}{l}1,660 \\
\text { ace runs }\end{array}$ & 2,520 & 3,890 & 5,140 & 6,580 & 8,230 & 10,800 & REG 43 & 1931-93 & 1935 & 15,000 \\
\hline
\end{tabular}


Table B2. Peak-flow frequency data for streamflow-gaging stations in Nebraska and for selected out-of-state stations,

and drainage areas for regulated streams--Continued

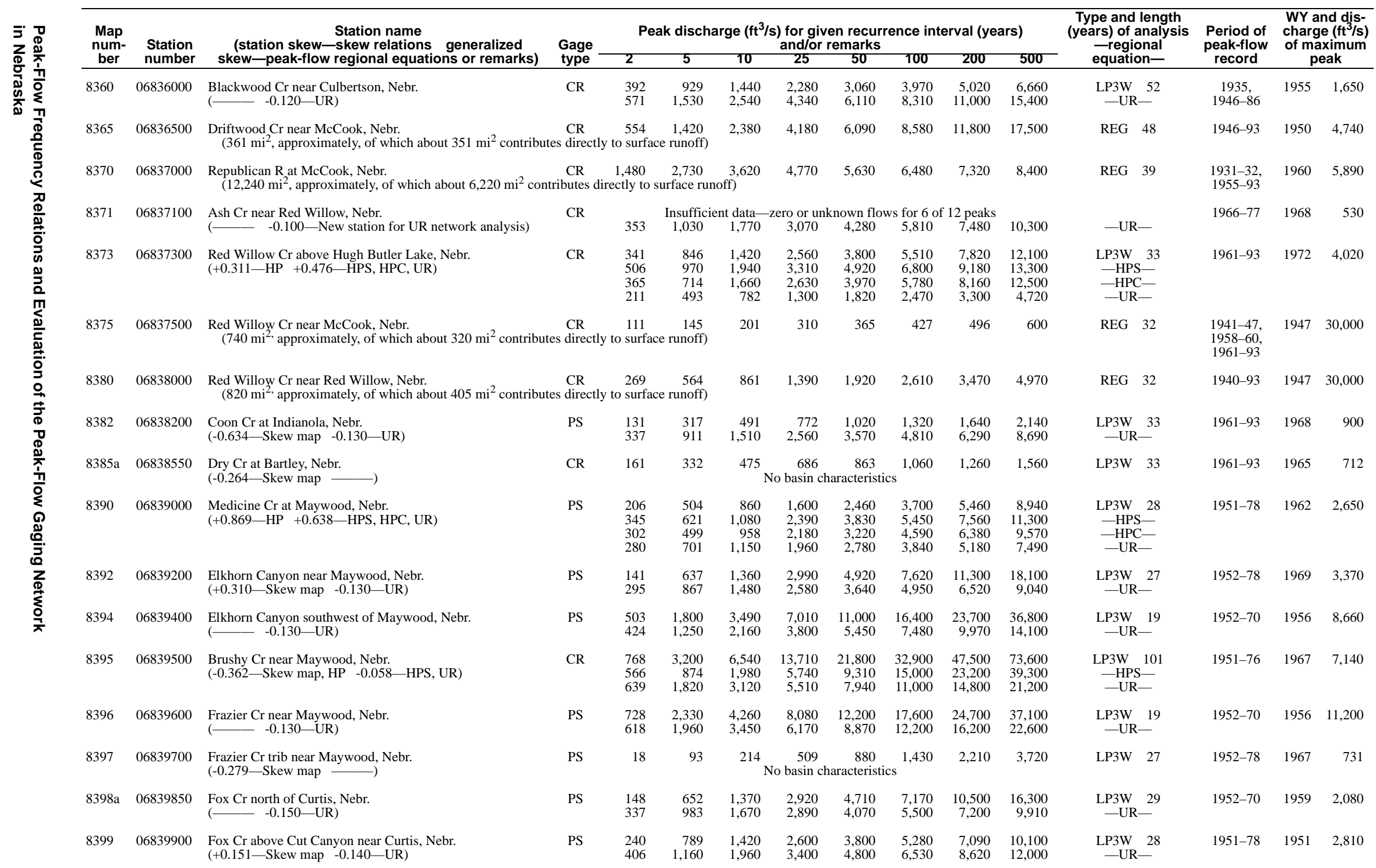


Table B2. Peak-flow frequency data for streamflow-gaging stations in Nebraska and for selected out-of-state stations,

and drainage areas for regulated streams--Continued

\begin{tabular}{|c|c|c|c|c|c|c|c|c|c|c|c|c|c|c|c|}
\hline \multirow{3}{*}{$\begin{array}{c}\begin{array}{c}\text { Map } \\
\text { num- } \\
\text { ber }\end{array} \\
8399 b\end{array}$} & \multirow{3}{*}{$\begin{array}{c}\begin{array}{c}\text { Station } \\
\text { number }\end{array} \\
06839950\end{array}$} & \multirow{3}{*}{$\begin{array}{c}\begin{array}{c}\text { Station name } \\
\text { (station skew } \\
\text { skew relations generalized } \\
\text { skew-peak-flow regional equations or remarks) }\end{array} \\
\begin{array}{l}\text { Cut Canyon near Curtis, Nebr. } \\
(+0.149-\text { Skew map }-0.140-\text { UR })\end{array}\end{array}$} & \multirow{3}{*}{$\begin{array}{c}\begin{array}{c}\text { Gage } \\
\text { type }\end{array} \\
\text { PS }\end{array}$} & \multirow{2}{*}{\multicolumn{8}{|c|}{ 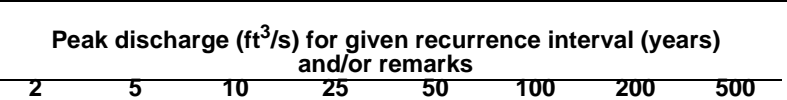 }} & \multirow{3}{*}{$\begin{array}{c}\begin{array}{c}\text { Type and length } \\
\text { (years) of analysis } \\
\text {-regional } \\
\text { equation- }\end{array} \\
\begin{array}{c}\text { LP3W } 28 \\
\text {-UR_- }\end{array}\end{array}$} & \multirow{3}{*}{$\begin{array}{c}\begin{array}{c}\text { Period of } \\
\text { peak-flow } \\
\text { record }\end{array} \\
1951-78\end{array}$} & \multirow{2}{*}{\multicolumn{2}{|c|}{$\begin{array}{c}\text { WY and dis- } \\
\text { charge }\left(\mathrm{ft}^{3} / \mathrm{s}\right) \\
\text { of maximum } \\
\text { peak }\end{array}$}} \\
\hline & & & & & & & & & & & & & & & \\
\hline & & & & $\begin{array}{l}320 \\
218\end{array}$ & $\begin{array}{l}742 \\
573\end{array}$ & $\begin{array}{r}1,120 \\
942\end{array}$ & $\begin{array}{l}1,700 \\
1,590\end{array}$ & $\begin{array}{l}2,210 \\
2,230\end{array}$ & $\begin{array}{l}2,780 \\
3,020\end{array}$ & $\begin{array}{l}3,390 \\
3,980\end{array}$ & $\begin{array}{l}4,300 \\
5,550\end{array}$ & & & 1952 & 1,560 \\
\hline 8400 & 06840000 & $\begin{array}{l}\text { Fox Cr at Curtis, Nebr. } \\
(+0.035-\text { Skew map }-0.140-U R)\end{array}$ & CR, PS & $\begin{array}{l}429 \\
502\end{array}$ & $\begin{array}{l}1,130 \\
1,400\end{array}$ & $\begin{array}{l}1,820 \\
2,370\end{array}$ & $\begin{array}{l}2,970 \\
4,120\end{array}$ & $\begin{array}{l}4,030 \\
5,860\end{array}$ & $\begin{array}{l}5,250 \\
8,020\end{array}$ & $\begin{array}{r}6,650 \\
10,700\end{array}$ & $\begin{array}{r}8,790 \\
15,000\end{array}$ & $\begin{array}{l}\mathrm{LP} 3 \mathrm{~W} \\
-\mathrm{UR}-\end{array}$ & $\begin{array}{l}1951-58 \\
1961-70 \\
1978-93\end{array}$ & 1951 & 3,340 \\
\hline 8405 & 06840500 & $\begin{array}{l}\text { Dry Cr near Curtis, Nebr. } \\
(--0.140-\mathrm{UR})\end{array}$ & CR, PS & $\begin{array}{l}772 \\
314\end{array}$ & $\begin{array}{r}2,050 \\
879\end{array}$ & $\begin{array}{l}3,440 \\
1,500\end{array}$ & $\begin{array}{l}6,000 \\
2,540\end{array}$ & $\begin{array}{l}8,630 \\
3,590\end{array}$ & $\begin{array}{r}12,000 \\
4,870\end{array}$ & $\begin{array}{r}16,200 \\
6,420\end{array}$ & $\begin{array}{r}23,500 \\
8,940\end{array}$ & $\begin{array}{l}\text { LP3W } \\
-\mathrm{UR}-\end{array}$ & $\begin{array}{l}1947, \\
1951-58 \\
1960-70\end{array}$ & 1951 & 4,430 \\
\hline 8410 & 06841000 & $\begin{array}{l}\text { Medicine } \mathrm{Cr} \text { above Harry Strunk Lake, Nebr. } \\
\left(770 \mathrm{mi}^{2} \text {, approximately, of which about } 530 \mathrm{mi}^{2} \text { contributes }\right.\end{array}$ & $\begin{array}{l}\text { CR } \\
\text { s directly }\end{array}$ & $\begin{array}{l}1,430 \\
\text { to surface }\end{array}$ & $\begin{array}{l}3,600 \\
\text { runoff) }\end{array}$ & 5,960 & 10,400 & 15,000 & 21,000 & 28,600 & 42,200 & REG 44 & 1950-93 & 1967 & 11,600 \\
\hline 8415 & 06841500 & $\begin{array}{l}\text { Mitchell Cr above Harry Strunk Lake, Nebr. } \\
(-0.341 \text {-Skew map -0.140-UR })\end{array}$ & $\mathrm{CR}$ & $\begin{array}{l}522 \\
243\end{array}$ & $\begin{array}{r}1,680 \\
634\end{array}$ & $\begin{array}{l}3,020 \\
1,040\end{array}$ & $\begin{array}{l}5,530 \\
1,740\end{array}$ & $\begin{array}{l}8,120 \\
2,410\end{array}$ & $\begin{array}{r}11,400 \\
3,240\end{array}$ & $\begin{array}{r}15,400 \\
4,220\end{array}$ & $\begin{array}{r}22,100 \\
5,830\end{array}$ & $\begin{array}{l}\mathrm{LP} 3 \mathrm{~W} \\
-\mathrm{UR}-\end{array}$ & 1950-74 & 1951 & 5,230 \\
\hline 8425 & 06842500 & $\begin{array}{l}\text { Medicine Cr below Harry Strunk Lake, Nebr. } \\
\left(900 \mathrm{mi}^{2} \text {, approximately, of which about } 655 \mathrm{mi}^{2} \text { contributes }\right.\end{array}$ & $\begin{array}{l}\text { CR } \\
\text { s directly }\end{array}$ & $\begin{array}{l}384 \\
\text { to surface }\end{array}$ & $\begin{array}{l}539 \\
\text { runoff) }\end{array}$ & 665 & 855 & 1,020 & 1,210 & 1,430 & 1,760 & REG 44 & $1950-93$ & 1960 & 1,300 \\
\hline 8435 & 06843500 & $\begin{array}{l}\text { Republican } \mathrm{R} \text { at Cambridge, Nebr. } \\
\quad\left(14,460 \mathrm{mi}^{2} \text {, approximately, of which about } 7,780 \mathrm{mi}^{2} \text { contri }\right.\end{array}$ & $\begin{array}{l}\mathrm{CR} \\
\text { ibutes dir }\end{array}$ & $\begin{array}{l}1,800 \\
\text { ectly to su }\end{array}$ & $\begin{array}{l}3,350 \\
\text { irface runoff }\end{array}$ & $\begin{array}{l}4,690 \\
\text { ff) }\end{array}$ & 6,700 & 8,600 & 10,700 & 13,100 & 16,800 & REG 32 & $1946-93$ & 1947 & 160,000 \\
\hline 8440 & 06844000 & $\begin{array}{l}\text { Muddy Cr at Arapahoe, Nebr. } \\
(\longleftarrow-0.150-\mathrm{UR})\end{array}$ & CR & $\begin{array}{r}1,100 \\
538\end{array}$ & $\begin{array}{l}2,790 \\
1,470\end{array}$ & $\begin{array}{l}4,500 \\
2,440\end{array}$ & $\begin{array}{l}7,450 \\
4,160\end{array}$ & $\begin{array}{r}10,300 \\
5,820\end{array}$ & $\begin{array}{r}13,700 \\
7,830\end{array}$ & $\begin{array}{l}17,800 \\
10,200\end{array}$ & $\begin{array}{l}24,300 \\
14,100\end{array}$ & $\begin{array}{l}\mathrm{LP} 3 \mathrm{~W} \\
-\mathrm{UR}-\end{array}$ & $\begin{array}{l}\text { 1947, } \\
1951-72 \\
1978-93\end{array}$ & 1986 & 10,800 \\
\hline $8442 a$ & 06844210 & $\begin{array}{l}\text { Turkey } \mathrm{Cr} \text { at Edison, Nebr. } \\
\left(\begin{array}{c}(-0.210-\mathrm{UR})\end{array}\right.\end{array}$ & CR & $\begin{array}{l}364 \\
395\end{array}$ & $\begin{array}{r}721 \\
1,070\end{array}$ & $\begin{array}{l}1,010 \\
1,790\end{array}$ & $\begin{array}{l}1,410 \\
3,070\end{array}$ & $\begin{array}{l}1,740 \\
4,330\end{array}$ & $\begin{array}{l}2,080 \\
5,890\end{array}$ & $\begin{array}{l}2,440 \\
7,790\end{array}$ & $\begin{array}{r}2,950 \\
10,900\end{array}$ & $\begin{array}{l}\mathrm{LP} 3 \mathrm{~W} \\
\text {-UR- }\end{array}$ & 1978-93 & 1993 & 1,040 \\
\hline 8445 & 06844500 & $\begin{array}{l}\text { Republican } \mathrm{R} \text { near Orleans, Nebr. } \\
\quad\left(15,580 \mathrm{mi}^{2} \text {, approximately, of which about } 8,880 \mathrm{mi}^{2} \text { contri }\right.\end{array}$ & $\begin{array}{l}\mathrm{CR} \\
\text { ibutes dir }\end{array}$ & $\begin{array}{l}2,470 \\
\text { ectly to su }\end{array}$ & $\begin{array}{l}4,580 \\
\text { Irface runoff }\end{array}$ & (ff) & 8,570 & 10,500 & 12,500 & 14,600 & 17,600 & REG 32 & $1948-93$ & 1948 & 40,600 \\
\hline 8448 & 06844800 & $\begin{array}{l}\text { S Fk Sappa Cr trib near Goodland, Kansas } \\
(+0.027 \text {-Skew map } \longrightarrow)\end{array}$ & PS & & Out-of & f-state st & ation used & only for s & kew relati & $\mathrm{n}(\mathrm{s})$ & & & $1957-89$ & 1979 & 3,450 \\
\hline 8449 & 06844900 & $\begin{array}{l}\text { S Fk Sappa Cr near Achilles, Kansas } \\
(-0.041 \text {-Skew map }-0.050 \text {-UR })\end{array}$ & CR & $\begin{array}{l}303 \\
418\end{array}$ & $\begin{array}{l}1,250 \\
1,070\end{array}$ & $\begin{array}{l}2,550 \\
1,740\end{array}$ & $\begin{array}{l}5,300 \\
2,920\end{array}$ & $\begin{array}{l}8,390 \\
4,070\end{array}$ & $\begin{array}{r}12,600 \\
5,490\end{array}$ & $\begin{array}{r}18,100 \\
7,200\end{array}$ & $\begin{array}{l}27,800 \\
10,000\end{array}$ & $\begin{array}{l}\text { LP3W } 34 \\
\text {-UR- }\end{array}$ & 1960-93 & 1975 & 5,310 \\
\hline 8450 & 06845000 & $\begin{array}{l}\text { Sappa Cr near Oberlin, Kansas } \\
(+0.224 \text {-Skew map }-0.050 \text {-UR })\end{array}$ & CR & $\begin{array}{r}866 \\
1,000\end{array}$ & $\begin{array}{l}2,510 \\
2,770\end{array}$ & $\begin{array}{l}4,386 \\
4,660\end{array}$ & $\begin{array}{l}7,970 \\
8,010\end{array}$ & $\begin{array}{l}11,700 \\
11,300\end{array}$ & $\begin{array}{l}16,600 \\
15,300\end{array}$ & $\begin{array}{l}22,900 \\
20,200\end{array}$ & $\begin{array}{l}33,800 \\
28,000\end{array}$ & $\begin{array}{l}\text { LP3W } 33 \\
\text {-UR- }\end{array}$ & $\begin{array}{l}1929-32 \\
1944-72\end{array}$ & 1944 & 10,600 \\
\hline 8451 & 06845100 & $\begin{array}{l}\text { Long Br Draw near Norcatur, Kansas } \\
(-0.058 \text {-Skew map }-0.080 \text {-UR })\end{array}$ & PS & $\begin{array}{l}287 \\
389\end{array}$ & $\begin{array}{r}737 \\
1,120\end{array}$ & $\begin{array}{l}1,200 \\
1,890\end{array}$ & $\begin{array}{l}1,990 \\
3,250\end{array}$ & $\begin{array}{l}2,770 \\
4,560\end{array}$ & $\begin{array}{l}3,700 \\
6,150\end{array}$ & $\begin{array}{l}4,830 \\
8,030\end{array}$ & $\begin{array}{r}6,650 \\
11,000\end{array}$ & $\begin{array}{c}\text { LP3W } 37 \\
\text {-UR- }\end{array}$ & 1957-93 & 1957 & 2,680 \\
\hline 8452 & 06845200 & $\begin{array}{l}\text { Sappa Cr near Beaver City, Nebr. } \\
(-0.134 \text {-Skew map }-0.050 \text {-UR })\end{array}$ & CR & $\begin{array}{r}1,350 \\
691\end{array}$ & $\begin{array}{l}2,780 \\
1,770\end{array}$ & $\begin{array}{l}4,040 \\
2,900\end{array}$ & $\begin{array}{l}5,970 \\
4,890\end{array}$ & $\begin{array}{l}7,670 \\
6,860\end{array}$ & $\begin{array}{l}9,580 \\
9,300\end{array}$ & $\begin{array}{l}11,700 \\
12,300\end{array}$ & $\begin{array}{l}15,000 \\
17,200\end{array}$ & $\begin{array}{c}\text { LP3W } 48 \\
\text {-UR- }\end{array}$ & $1937-72$ & 1966 & 9,500 \\
\hline 8460 & 06846000 & $\begin{array}{l}\text { Beaver Cr at Ludell, Kansas } \\
(-0.026-\text { Skew map }-0.050-U R)\end{array}$ & CR & $\begin{array}{r}446 \\
1,040\end{array}$ & $\begin{array}{l}1,110 \\
2,830\end{array}$ & $\begin{array}{l}1,780 \\
4,740\end{array}$ & $\begin{array}{l}2,950 \\
8,150\end{array}$ & $\begin{array}{r}4,070 \\
11,500\end{array}$ & $\begin{array}{r}5,430 \\
15,600\end{array}$ & $\begin{array}{r}7,060 \\
20,600\end{array}$ & $\begin{array}{r}9,700 \\
28,700\end{array}$ & $\begin{array}{l}\mathrm{LP} 3 \mathrm{~W} \\
-\mathrm{UR}-\end{array}$ & $\begin{array}{l}1929-32 \\
1946-53 \\
1961-88\end{array}$ & 1965 & 3,800 \\
\hline 8462 & 06846200 & $\begin{array}{l}\text { Beaver Cr trib near Ludell, Kansas } \\
(-0.884-\text { Skew map } \\
(\longrightarrow\end{array}$ & PS & 342 & $\begin{array}{l}621 \\
\text { Out-of- } \\
\text { Appea }\end{array}$ & $\begin{array}{l}837 \\
\text { sf-state st } \\
\text { ears to rec }\end{array}$ & $\begin{array}{l}1,140 \\
\text { ion used } \\
\text { lire comp }\end{array}$ & $\begin{array}{l}1,380 \\
\text { only for s } \\
\text { osite freq }\end{array}$ & $\begin{array}{c}1,630 \\
\text { ew relatit }\end{array}$ & $\begin{array}{l}1,900 \\
\text { nn(s) } \\
\text { ysis }\end{array}$ & 2,280 & LP3W 33 & 1957-89 & 1975 & 880 \\
\hline
\end{tabular}


Table B2. Peak-flow frequency data for streamflow-gaging stations in Nebraska and for selected out-of-state stations,

and drainage areas for regulated streams--Continued

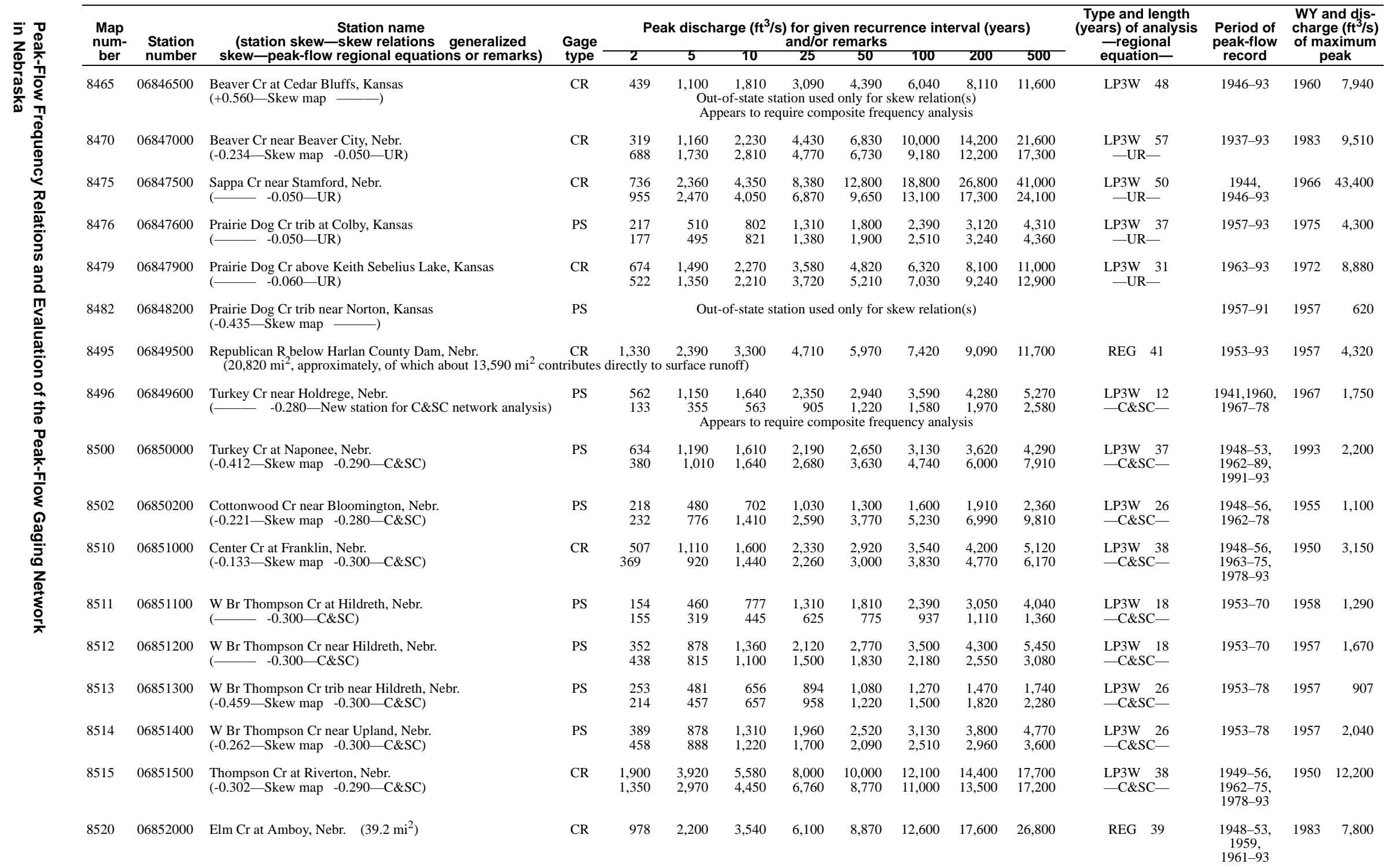


Table B2. Peak-flow frequency data for streamflow-gaging stations in Nebraska and for selected out-of-state stations,

and drainage areas for regulated streams--Continued

\begin{tabular}{|c|c|c|c|c|c|c|c|c|c|c|c|c|c|c|c|}
\hline \multirow{2}{*}{$\begin{array}{c}\begin{array}{c}\text { Map } \\
\text { num- } \\
\text { ber }\end{array} \\
8530 \mathrm{a}\end{array}$} & \multirow{2}{*}{$\begin{array}{c}\begin{array}{c}\text { Station } \\
\text { number }\end{array} \\
06853020\end{array}$} & \multirow{2}{*}{$\begin{array}{l}\text { Station name } \\
\text { (station skew-skew relations generalized } \\
\text { skew-peak-flow regional equations or remarks) } \\
\text { Republican R at Guide Rock, Nebr. } \\
\text { (Includes record for Republican R Rear Guide Rock, } 068530 \\
\left(22,030 \mathrm{mi}^{2}, \text { approximately, of which about } 14,560 \mathrm{mi}^{2} \text { con }\right.\end{array}$} & \multirow{2}{*}{$\begin{array}{c}\begin{array}{c}\text { Gage } \\
\text { type }\end{array} \\
\text { CR } \\
00,195 \\
\text { tributes }\end{array}$} & \multicolumn{8}{|c|}{$\begin{array}{l}\text { Peak discharge }\left(\mathrm{ft}^{3} / \mathbf{s}\right) \text { for given recurrence interval (years) } \\
\text { and/or remarks }\end{array}$} & $\begin{array}{c}\text { Type and length } \\
\text { (years) of analysis } \\
\text {-regional } \\
\text { equation- }\end{array}$ & \multirow{2}{*}{$\begin{array}{c}\begin{array}{c}\text { Period of } \\
\text { peak-flow } \\
\text { record }\end{array} \\
1950-93\end{array}$} & \multicolumn{2}{|c|}{$\begin{array}{l}\text { WY and dis- } \\
\left.\text { charge ( } \mathrm{ft}^{3} / \mathrm{s}\right) \\
\text { of maximum } \\
\text { peak }\end{array}$} \\
\hline & & & & $\begin{array}{r}3,860 \\
-1984) \\
\text { irectly to }\end{array}$ & $\begin{array}{c}6,780 \\
\text { surface } \mathrm{r}\end{array}$ & $\begin{array}{l}9,500 \\
\text { noff) }\end{array}$ & 14,100 & 18,500 & 24,000 & 30,800 & 42,300 & REG 41 & & 1957 & 29,200 \\
\hline 8531 & 06853100 & $\begin{array}{l}\text { Beaver Cr near Rosemont, Nebr. } \\
(-0.229 \text {-Skew map } \longrightarrow)\end{array}$ & $\mathrm{CR}$ & 192 & 433 & 655 & 1,010 & $\begin{array}{ll}1,330 \\
1 \mathrm{mi}^{2}\end{array}$ & 1,710 & 2,130 & 2,790 & LP3W 40 & 1939-78 & 1959 & 970 \\
\hline 8535 & 06853500 & $\begin{array}{l}\text { Republican R near Hardy, Nebr. } \\
\left(22,400 \mathrm{mi}^{2} \text {, of which about } 7,500 \mathrm{mi}^{2} \text { does not contribute }\right.\end{array}$ & $\begin{array}{ll}\mathrm{CR} \\
\text { lirectly t }\end{array}$ & $\begin{array}{l}4,850 \\
\text { surface }\end{array}$ & $\begin{array}{ll}8,490 \\
\text { unoff- }-\mathrm{f}\end{array}$ & $\begin{array}{l}11,700 \\
\text { om Booha }\end{array}$ & $\begin{array}{l}16,700 \\
\text { r and other }\end{array}$ & $\begin{array}{l}21,200 \\
\mathrm{~s}, 1995)\end{array}$ & 26,600 & 32,900 & 42,800 & REG 41 & $\begin{array}{l}\text { 1903-15, } \\
1932-93\end{array}$ & 1935 & 225,000 \\
\hline 8538 & 06853800 & $\begin{array}{l}\text { White Rock Cr near Burr Oak, Kansas } \\
(+0.476 \text {-Skew map }-)\end{array}$ & $\mathrm{CR}$ & & & of-state st & ation used & only for s & kew relati & $\mathrm{n}(\mathrm{s})$ & & & 1955-93 & 1973 & 15,800 \\
\hline 8561 & 06856100 & $\begin{array}{l}\text { West Cr near Talmo, Kansas } \\
(+0.401-\text { Skew map }\end{array}$ & PS & & & of-state st & ation used & only for s & kew relati & $\mathrm{n}(\mathrm{s})$ & & & $\begin{array}{c}1941, \\
1957-89\end{array}$ & 1941 & 15,000 \\
\hline 8568 & 06856800 & $\begin{array}{l}\text { Moll Cr near Green, Kansas } \\
(-0.224 \text {-Skew map } \longrightarrow\end{array}$ & PS & & & of-state st & ation used & only for s & kew relati & n $(\mathrm{s})$ & & & 1957-90 & 1964 & 1,780 \\
\hline 8710 & 06871000 & $\begin{array}{l}\text { N Fk Solomon R at Glade, Kansas } \\
(-0.217-\text { Skew map } \longrightarrow)\end{array}$ & $\mathrm{CR}$ & & & of-state st & ation used & only for $\mathrm{s}$ & kew relati & $\mathrm{n}(\mathrm{s})$ & & & $1952-93$ & 1957 & 23,300 \\
\hline 8715 & 06871500 & $\begin{array}{l}\text { Bow Cr near Stockton, Kansas } \\
(+0.222 \text {-Skew map }\end{array}$ & CR & & & of-state st & ation used & only for $\mathrm{s}$ & kew relati & nn(s) & & & 1950-93 & 1951 & 12,900 \\
\hline 8726 & 06872600 & $\begin{array}{l}\text { Oak Cr at Bellaire, Kansas } \\
(-0.198-\text {-Skew map }\end{array}$ & PS & & & of-state st & ation used & only for $\mathrm{s}$ & kew relati & $\mathrm{n}(\mathrm{s})$ & & & 1957-89 & 1957 & 1,500 \\
\hline 8730 & 06873000 & $\begin{array}{l}\text { S Fk Solomon } R \text { above Webster Reservoir, } \\
\text { Kansas }(-0.095-\text { Skew map }\end{array}$ & CR & & & of-state st & ation used & only for $\mathrm{s}$ & kew relati & nn(s) & & & $\begin{array}{l}1908,1935 \\
1945-93\end{array}$ & 1951 & 55,200 \\
\hline 8733 & 06873300 & $\begin{array}{l}\text { Ash Cr trib near Stockton, Kansas } \\
(-0.010 \text { - Skew map }-)\end{array}$ & PS & & & of-state st & ation used & only for $\mathrm{s}$ & kew relati & $\mathrm{n}(\mathrm{s})$ & & & 1957-93 & 1987 & 760 \\
\hline 8735 & 06873500 & $\begin{array}{l}\text { S Fk Solomon } R \text { at Alton, Kansas } \\
(+0.117 \text {-Skew map } \longrightarrow)\end{array}$ & CR & & & of-state st & ation used & only for $\mathrm{s}$ & kew relati & nn(s) & & & $\begin{array}{l}\text { 1919-25, } \\
1928-32, \\
1942-57\end{array}$ & 1951 & 91,900 \\
\hline 8745 & 06874500 & $\begin{array}{l}\text { East Limestone Cr near Ionia, Kansas } \\
(-0.216 \text {-Skew map } \longrightarrow)\end{array}$ & CR & & & of-state st & ation used & only for $\mathrm{s}$ & kew relati & n $(\mathrm{s})$ & & & $\begin{array}{l}1934-38, \\
1957-89\end{array}$ & 1935 & 3,920 \\
\hline 8799 & 06879900 & $\begin{array}{l}\text { Big Blue R at Surprise, Nebr. } \\
(--0.137-\mathrm{BB})\end{array}$ & CR & $\begin{array}{l}1,690 \\
1,490\end{array}$ & $\begin{array}{l}2,990 \\
2,800\end{array}$ & $\begin{array}{l}4,010 \\
3,990\end{array}$ & $\begin{array}{l}5,450 \\
5,770\end{array}$ & $\begin{array}{l}6,630 \\
7,130\end{array}$ & $\begin{array}{l}7,900 \\
8,590\end{array}$ & $\begin{array}{r}9,260 \\
10,200\end{array}$ & $\begin{array}{l}11,200 \\
12,400\end{array}$ & $\begin{array}{l}\mathrm{LP} 3 \mathrm{~W} \quad 30 \\
-\mathrm{BB}-\end{array}$ & 1964-93 & 1965 & 10,700 \\
\hline 8800 & 06880000 & $\begin{array}{l}\text { Lincoln Cr near Seward, Nebr. } \\
\begin{array}{l}(-0.180-\text { Skew map, SE }-0.161-B B)\end{array}\end{array}$ & $\mathrm{CR}$ & $\begin{array}{l}1,450 \\
1,910\end{array}$ & $\begin{array}{l}3,010 \\
3,300\end{array}$ & $\begin{array}{l}4,350 \\
4,610\end{array}$ & $\begin{array}{l}6,360 \\
6,300\end{array}$ & $\begin{array}{l}8,100 \\
7,800\end{array}$ & $\begin{array}{r}10,000 \\
9,400\end{array}$ & $\begin{array}{l}12,100 \\
11,100\end{array}$ & $\begin{array}{l}15,300 \\
13,600\end{array}$ & $\begin{array}{c}\mathrm{LP} 3 \mathrm{~W} \quad 40 \\
-\mathrm{BB}-\end{array}$ & 1954-93 & 1957 & 10,100 \\
\hline 8805 & 06880500 & $\begin{array}{l}\text { Big Blue R at Seward, Nebr. } \\
(-0.222-\text { Skew map, SE }-0.162-B B)\end{array}$ & CR & $\begin{array}{l}3,230 \\
3,430\end{array}$ & $\begin{array}{l}6,770 \\
7,180\end{array}$ & $\begin{array}{r}9,810 \\
10,100\end{array}$ & $\begin{array}{l}14,400 \\
14,600\end{array}$ & $\begin{array}{l}18,300 \\
18,100\end{array}$ & $\begin{array}{l}22,700 \\
21,900\end{array}$ & $\begin{array}{l}27,500 \\
25,900\end{array}$ & $\begin{array}{l}34,500 \\
31,600\end{array}$ & $\begin{array}{l}\mathrm{LP} 3 \mathrm{~W} \\
-\mathrm{BB}-\end{array}$ & 1954-93 & 1957 & 15,300 \\
\hline $8805 b$ & 06880508 & $\begin{array}{l}\text { Plum Cr near Seward, Nebr. } \\
(--0.239-\mathrm{BB})\end{array}$ & PS & $\begin{array}{l}626 \\
968\end{array}$ & $\begin{array}{l}1,160 \\
1,950\end{array}$ & $\begin{array}{l}1,580 \\
2,840\end{array}$ & $\begin{array}{l}2,160 \\
4,210\end{array}$ & $\begin{array}{l}2,630 \\
5,300\end{array}$ & $\begin{array}{l}3,120 \\
6,460\end{array}$ & $\begin{array}{l}3,640 \\
7,730\end{array}$ & $\begin{array}{l}4,370 \\
9,540\end{array}$ & $\begin{array}{l}\mathrm{LP} 3 \mathrm{~W} \\
-\mathrm{BB}-\end{array}$ & $\begin{array}{c}1963 \\
1968-78\end{array}$ & 1973 & 1,900 \\
\hline $8805 \mathrm{c}$ & 06880590 & $\begin{array}{l}\mathrm{N} \text { Br W Fk Big Blue R trib at Giltner, Nebr. } \\
(-0.159-\mathrm{BB})\end{array}$ & PS & $\begin{array}{l}317 \\
130\end{array}$ & $\begin{array}{l}594 \\
336\end{array}$ & $\begin{array}{l}814 \\
562\end{array}$ & $\begin{array}{l}1,130 \\
1,150\end{array}$ & $\begin{array}{l}1,390 \\
1,470\end{array}$ & $\begin{array}{l}1,660 \\
1,810\end{array}$ & $\begin{array}{l}1,960 \\
2,180\end{array}$ & $\begin{array}{l}2,380 \\
2,710\end{array}$ & $\begin{array}{c}\mathrm{LP} 3 \mathrm{~W} \\
-\mathrm{BB}-\end{array}$ & 1968-78 & 1974 & 945 \\
\hline
\end{tabular}


Table B2. Peak-flow frequency data for streamflow-gaging stations in Nebraska and for selected out-of-state stations,

and drainage areas for regulated streams--Continued

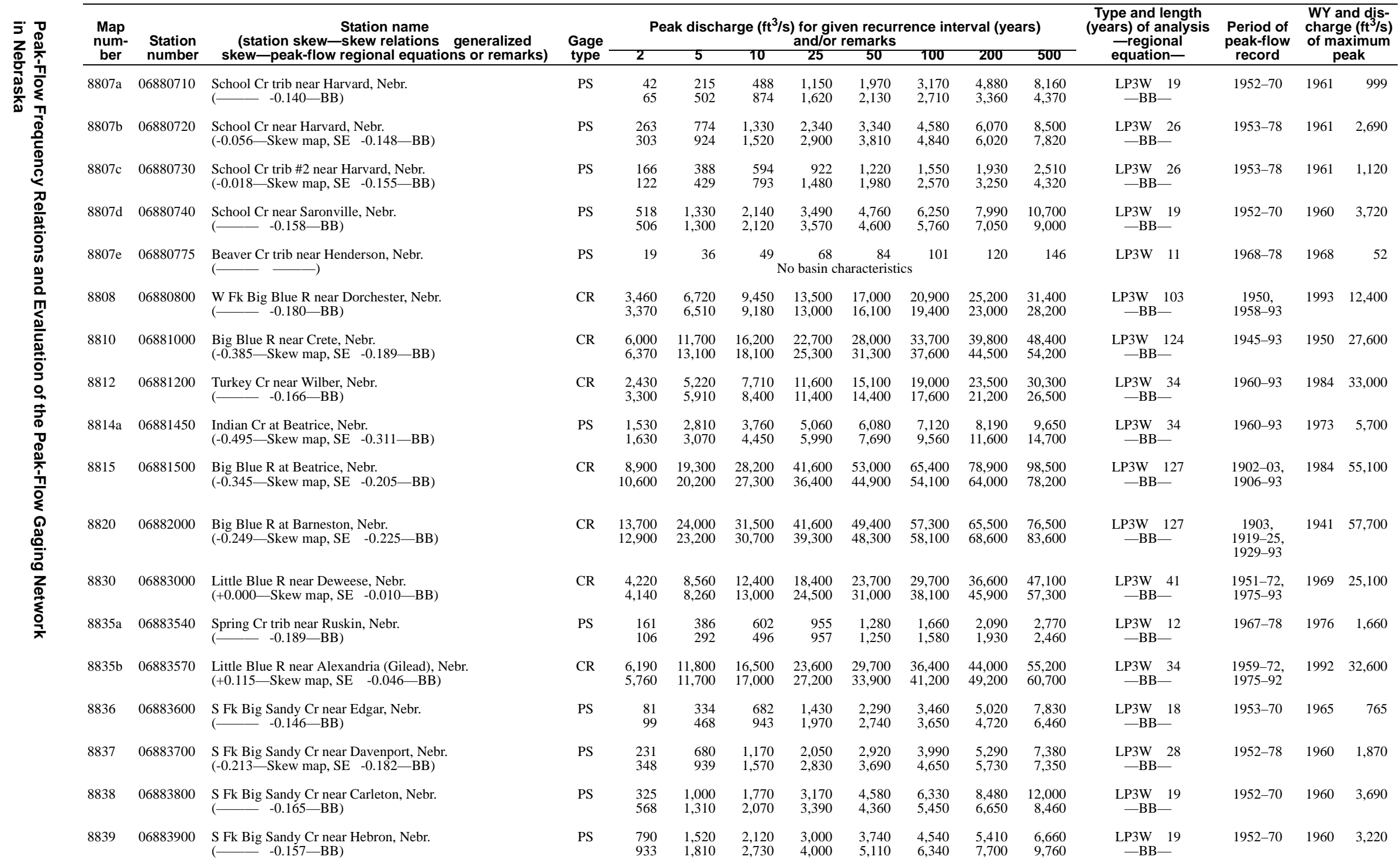


Table B2. Peak-flow frequency data for streamflow-gaging stations in Nebraska and for selected out-of-state stations,

and drainage areas for regulated streams--Continued

\begin{tabular}{|c|c|c|c|c|c|c|c|c|c|c|c|c|c|c|c|}
\hline \multirow{3}{*}{$\begin{array}{c}\begin{array}{c}\text { Map } \\
\text { num- } \\
\text { ber }\end{array} \\
8839 b\end{array}$} & \multirow{3}{*}{$\begin{array}{c}\begin{array}{c}\text { Station } \\
\text { number }\end{array} \\
06883940\end{array}$} & \multirow{3}{*}{$\begin{array}{l}\begin{array}{c}\text { Station name } \\
\text { (station skew—-skew relations generalized } \\
\text { skew-peak-flow regional equations or remarks) }\end{array} \\
\begin{array}{l}\text { Big Sandy Cr at Alexandria, Nebr. } \\
(--0.051-\mathrm{BB})\end{array}\end{array}$} & \multirow{3}{*}{$\begin{array}{l}\text { Gage } \\
\text { type }\end{array}$} & \multicolumn{8}{|c|}{$\begin{array}{l}\left.\text { Peak discharge ( } \mathrm{ft}^{3} / \mathrm{s}\right) \text { for given recurrence interval (years) } \\
\text { and/or remarks }\end{array}$} & \multirow{3}{*}{$\begin{array}{c}\begin{array}{c}\text { Type and length } \\
\text { (years) of analysis } \\
\text {-regional } \\
\text { equation- }\end{array} \\
\begin{array}{c}\text { LP3W } 14 \\
\text { - BB- }\end{array}\end{array}$} & \multirow{3}{*}{$\begin{array}{c}\begin{array}{c}\text { Period of } \\
\text { peak-flow } \\
\text { record }\end{array} \\
1980-93\end{array}$} & \multirow{2}{*}{\multicolumn{2}{|c|}{$\begin{array}{c}\text { WY and dis- } \\
\left.\text { charge ( } \mathrm{ft}^{3} / \mathrm{s}\right) \\
\text { of maximum } \\
\text { peak }\end{array}$}} \\
\hline & & & & 2 & 5 & 10 & 25 & 50 & 100 & 200 & 500 & & & & \\
\hline & & & & $\begin{array}{l}3,990 \\
3,110\end{array}$ & $\begin{array}{l}9,380 \\
6,090\end{array}$ & $\begin{array}{r}14,600 \\
8,860\end{array}$ & $\begin{array}{l}23,200 \\
12,600\end{array}$ & $\begin{array}{l}31,300 \\
15,900\end{array}$ & $\begin{array}{l}40,900 \\
19,500\end{array}$ & $\begin{array}{l}52,200 \\
23,600\end{array}$ & $\begin{array}{l}69,900 \\
29,600\end{array}$ & & & 1984 & 21,900 \\
\hline $8839 \mathrm{c}$ & 06883955 & $\begin{array}{l}\text { Little Sandy Cr near Ohiowa, Nebr. } \\
(--0.181-\mathrm{BB})\end{array}$ & PS & $\begin{array}{l}308 \\
275\end{array}$ & $\begin{array}{l}738 \\
777\end{array}$ & $\begin{array}{l}1,140 \\
1,330\end{array}$ & $\begin{array}{l}1,790 \\
2,370\end{array}$ & $\begin{array}{l}2,380 \\
3,150\end{array}$ & $\begin{array}{l}3,050 \\
4,040\end{array}$ & $\begin{array}{l}3,810 \\
5,050\end{array}$ & $\begin{array}{l}4,960 \\
6,610\end{array}$ & $\begin{array}{l}\mathrm{LP} 3 \mathrm{~W} \\
-\mathrm{BB}-\end{array}$ & $1968-78$ & 1977 & 1,370 \\
\hline 8840 & 06884000 & $\begin{array}{l}\text { Little Blue R near Fairbury, Nebr. } \\
(-0.040-\text { Skew map, SE }-0.070-B B)\end{array}$ & CR & $\begin{array}{l}8,500 \\
7,960\end{array}$ & $\begin{array}{l}17,400 \\
15,700\end{array}$ & $\begin{array}{l}25,100 \\
22,300\end{array}$ & $\begin{array}{l}37,100 \\
33,500\end{array}$ & $\begin{array}{l}47,500 \\
41,700\end{array}$ & $\begin{array}{l}59,400 \\
50,700\end{array}$ & $\begin{array}{l}72,800 \\
60,500\end{array}$ & $\begin{array}{l}92,900 \\
74,700\end{array}$ & $\begin{array}{l}\mathrm{LP} 3 \mathrm{~W} \\
-\mathrm{BB}-\end{array}$ & $\begin{array}{l}\text { 1908-15, } \\
1929-56 \\
1957-93\end{array}$ & 1992 & 54,000 \\
\hline $8840 \mathrm{~b}$ & 06884005 & $\begin{array}{l}\text { Dry Br trib near Fairbury, Nebr. } \\
(--0.473-\text { BB })\end{array}$ & PS & $\begin{array}{l}225 \\
450\end{array}$ & $\begin{array}{r}697 \\
1,150\end{array}$ & $\begin{array}{l}1,180 \\
1,890\end{array}$ & $\begin{array}{l}1,980 \\
3,370\end{array}$ & $\begin{array}{l}2,690 \\
4,480\end{array}$ & $\begin{array}{l}3,490 \\
5,720\end{array}$ & $\begin{array}{l}4,380 \\
7,100\end{array}$ & $\begin{array}{l}5,670 \\
9,160\end{array}$ & $\begin{array}{l}\mathrm{LP} 3 \mathrm{~W} \\
-\mathrm{BB}-\end{array}$ & $1968-78$ & 1973 & 1,270 \\
\hline 8841 & 06884100 & $\begin{array}{l}\text { Mulberry Cr trib near Haddam, Kansas } \\
(-0.101 \text {-Skew map } \longrightarrow)\end{array}$ & PS & & & -of-state st & $\begin{array}{l}\text { ation used } \\
\text { o basin ch }\end{array}$ & $\begin{array}{l}\text { only for } \mathrm{s} \\
\text { aracteristi }\end{array}$ & ew relatic & $\mathrm{n}(\mathrm{s})$ & & & $\begin{array}{l}\text { 1957-72, } \\
1974-89\end{array}$ & 1968 & 2,000 \\
\hline 8842 & 06884200 & $\begin{array}{l}\text { Mill Cr at Washington, Kansas } \\
(-0.342-\text { Skew map }-0.130-B B)\end{array}$ & $\mathrm{CR}$ & $\begin{array}{l}5,100 \\
4,880\end{array}$ & $\begin{array}{l}8,610 \\
9,630\end{array}$ & $\begin{array}{l}11,200 \\
13,600\end{array}$ & $\begin{array}{l}14,700 \\
18,600\end{array}$ & $\begin{array}{l}17,500 \\
23,700\end{array}$ & $\begin{array}{l}20,300 \\
29,300\end{array}$ & $\begin{array}{l}23,300 \\
35,400\end{array}$ & $\begin{array}{l}27,300 \\
44,200\end{array}$ & $\begin{array}{c}\mathrm{LP} 3 \mathrm{~W} \quad 34 \\
-\mathrm{BB}-\end{array}$ & $1960-93$ & 1993 & 14,600 \\
\hline 8843 & 06884300 & $\begin{array}{l}\text { Mill Cr trib near Washington, Kansas } \\
(+0.117 \text {-Skew map }-0.110-\mathrm{BB})\end{array}$ & PS & $\begin{array}{l}543 \\
302\end{array}$ & $\begin{array}{r}1,140 \\
816\end{array}$ & $\begin{array}{l}1,670 \\
1,390\end{array}$ & $\begin{array}{l}2,510 \\
2,280\end{array}$ & $\begin{array}{l}3,260 \\
3,100\end{array}$ & $\begin{array}{l}4,110 \\
4,040\end{array}$ & $\begin{array}{l}5,090 \\
5,120\end{array}$ & $\begin{array}{l}6,580 \\
6,800\end{array}$ & $\begin{array}{l}\mathrm{LP} 3 \mathrm{~W} \quad 37 \\
-\mathrm{BB}-\end{array}$ & $1957-93$ & 1983 & 2,500 \\
\hline 8844 & 06884400 & $\begin{array}{l}\text { Little Blue R near Barnes, Kansas } \\
(-0.155 \text {-Skew map }-0.080-\mathrm{BB})\end{array}$ & $\mathrm{CR}$ & $\begin{array}{l}13,700 \\
12,800\end{array}$ & $\begin{array}{l}23,500 \\
22,900\end{array}$ & $\begin{array}{l}30,900 \\
31,000\end{array}$ & $\begin{array}{l}41,300 \\
42,300\end{array}$ & $\begin{array}{l}49,700 \\
52,400\end{array}$ & $\begin{array}{l}58,500 \\
63,300\end{array}$ & $\begin{array}{l}67,900 \\
75,200\end{array}$ & $\begin{array}{l}81,100 \\
92,300\end{array}$ & $\begin{array}{l}\mathrm{LP} 3 \mathrm{~W} \quad 36 \\
-\mathrm{BB}-\end{array}$ & $1958-93$ & 1973 & 53,700 \\
\hline 8845 & 06884500 & $\begin{array}{l}\text { Little Blue } R \text { at Waterville, Kansas } \\
(-0.076 \text {-Skew map }\end{array}$ & PS, CR & & & -of-state st & $\begin{array}{l}\text { ation used } \\
\text { o basin ch }\end{array}$ & $\begin{array}{l}\text { only for s } \\
\text { aracteristi }\end{array}$ & relatic & $\mathrm{n}(\mathrm{s})$ & & & $\begin{array}{c}1903, \\
1922-25 \\
1929-57\end{array}$ & 1903 & 73,000 \\
\hline 8855 & 06885500 & $\begin{array}{l}\text { Black Vermillion R near Frankfort, Kansas } \\
(-0.176 \text {-Skew map }-0.150-\mathrm{BB})\end{array}$ & $\mathrm{CR}$ & $\begin{array}{l}7,800 \\
7,460\end{array}$ & $\begin{array}{l}16,200 \\
15,900\end{array}$ & $\begin{array}{l}23,300 \\
21,900\end{array}$ & $\begin{array}{l}34,200 \\
27,500\end{array}$ & $\begin{array}{l}43,500 \\
35,300\end{array}$ & $\begin{array}{l}53,900 \\
43,800\end{array}$ & $\begin{array}{l}65,400 \\
53,100\end{array}$ & $\begin{array}{l}82,300 \\
66,700\end{array}$ & $\begin{array}{l}\mathrm{LP} 3 \mathrm{~W} \\
-\mathrm{BB}-\end{array}$ & 1953-93 & 1959 & 38,300 \\
\hline 8860 & 06886000 & $\begin{array}{l}\text { Big Blue } R \text { at Randolph, Kansas } \\
(+0.118-\text { Skew map }-)\end{array}$ & CR & & & of-state st & ation used & only for s & kew relatic & $\mathrm{n}(\mathrm{s})$ & & & $1918-60$ & 1951 & 77,800 \\
\hline 8865 & 06886500 & $\begin{array}{l}\text { Fancy Cr at Winkler, Kansas } \\
(-0.148-\text { Skew map }-0.110-\text { BB })\end{array}$ & $\mathrm{CR}$ & $\begin{array}{l}6,120 \\
3,730\end{array}$ & $\begin{array}{r}10,800 \\
7,320\end{array}$ & $\begin{array}{l}14,400 \\
10,400\end{array}$ & $\begin{array}{l}19,500 \\
13,200\end{array}$ & $\begin{array}{l}23,600 \\
17,000\end{array}$ & $\begin{array}{l}28,000 \\
21,200\end{array}$ & $\begin{array}{l}32,600 \\
25,900\end{array}$ & $\begin{array}{l}39,300 \\
32,900\end{array}$ & $\begin{array}{l}\mathrm{LP} 3 \mathrm{~W} \\
-\mathrm{BB}-\end{array}$ & $\begin{array}{l}1954-73 \\
1975-89\end{array}$ & 1972 & 24,000 \\
\hline 8872 & 06887200 & $\begin{array}{l}\text { Cedar Cr near Manhattan, Kansas } \\
(-0.273 \text {-Skew map -0.120-BB) }\end{array}$ & PS & $\begin{array}{l}1,560 \\
1,630\end{array}$ & $\begin{array}{l}3,610 \\
3,420\end{array}$ & $\begin{array}{l}5,510 \\
5,150\end{array}$ & $\begin{array}{l}8,560 \\
7,260\end{array}$ & $\begin{array}{r}11,300 \\
9,630\end{array}$ & $\begin{array}{l}14,500 \\
12,300\end{array}$ & $\begin{array}{l}18,100 \\
15,300\end{array}$ & $\begin{array}{l}23,600 \\
19,900\end{array}$ & $\begin{array}{l}\mathrm{LP} 3 \mathrm{~W} \\
-\mathrm{BB}-\end{array}$ & $1957-93$ & 1972 & 8,800 \\
\hline 8880 & 06888000 & $\begin{array}{l}\text { Vermillion Cr near Wamego, Kansas } \\
(-0.090-\text { Skew map }-)\end{array}$ & $\mathrm{CR}$ & & & -of-state st & ation used & only for $\mathrm{s}$ & kew relatic & $\mathrm{n}(\mathrm{s})$ & & & $\begin{array}{c}1915 \\
1936-46 \\
1951, \\
1954-85\end{array}$ & 1915 & 38,500 \\
\hline 8883 & 06888300 & $\begin{array}{l}\text { Rock Cr near Louisville, Kansas } \\
(-0.067 \text {-Skew map }-)\end{array}$ & $\mathrm{CR}$ & & & -of-state st & ation used & only for $\mathrm{s}$ & latic & $\mathrm{n}(\mathrm{s})$ & & & 1959-90 & 1968 & 20,000 \\
\hline
\end{tabular}


APPENDIX C-GRAPHS OF COMPOSITE PEAK-FLOW FREQUENCY CURVES FOR SELECTED STATIONS 

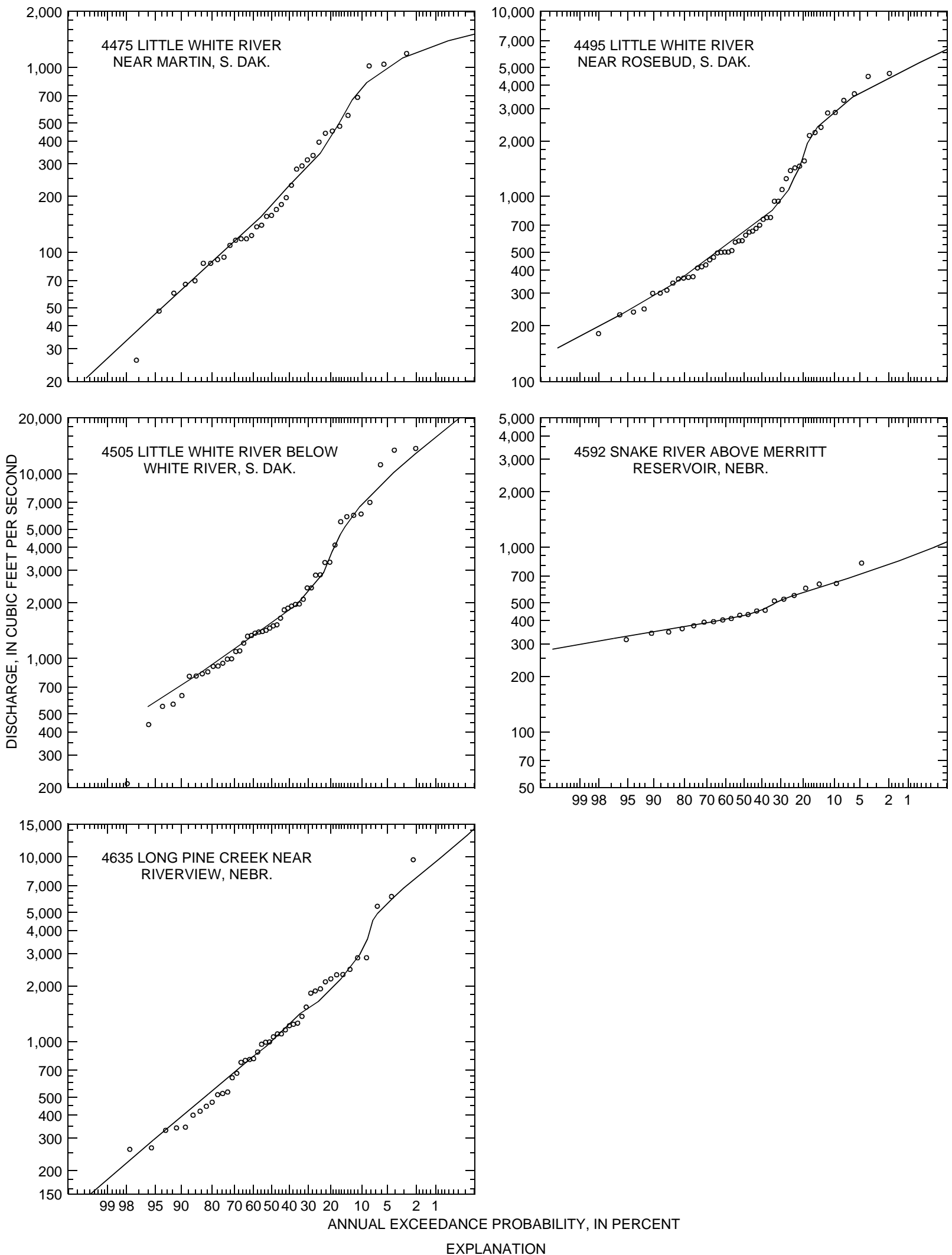

EXPLANATION

Composite frequency curve $\quad \circ \quad$ Annual maximum peak flow

Figure C1. Composite peak-flow frequency curves for selected Nebraska and South Dakota streamflow-gaging stations in the White and Niobrara River Basins with average soil permeability of the top 60 inches of more than 4 inches per hour. 

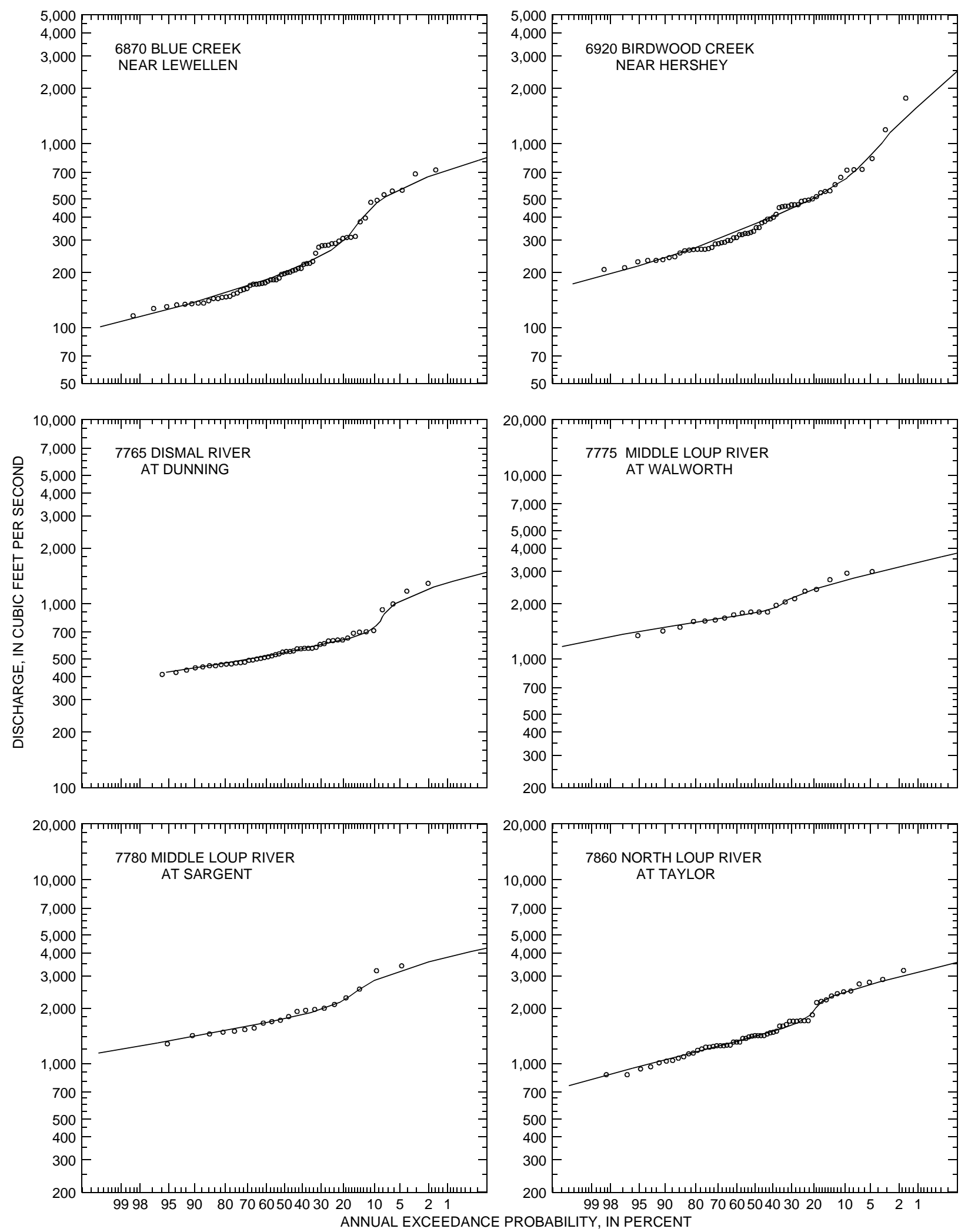

EXPLANATION

Composite frequency curve

Annual maximum peak flow

Figure C2. Composite peak-flow frequency curves for selected Nebraska streamflow-gaging stations in the North Platte and Platte River Basins with average soil permeability of the top 60 inches of more than 4 inches per hour. 

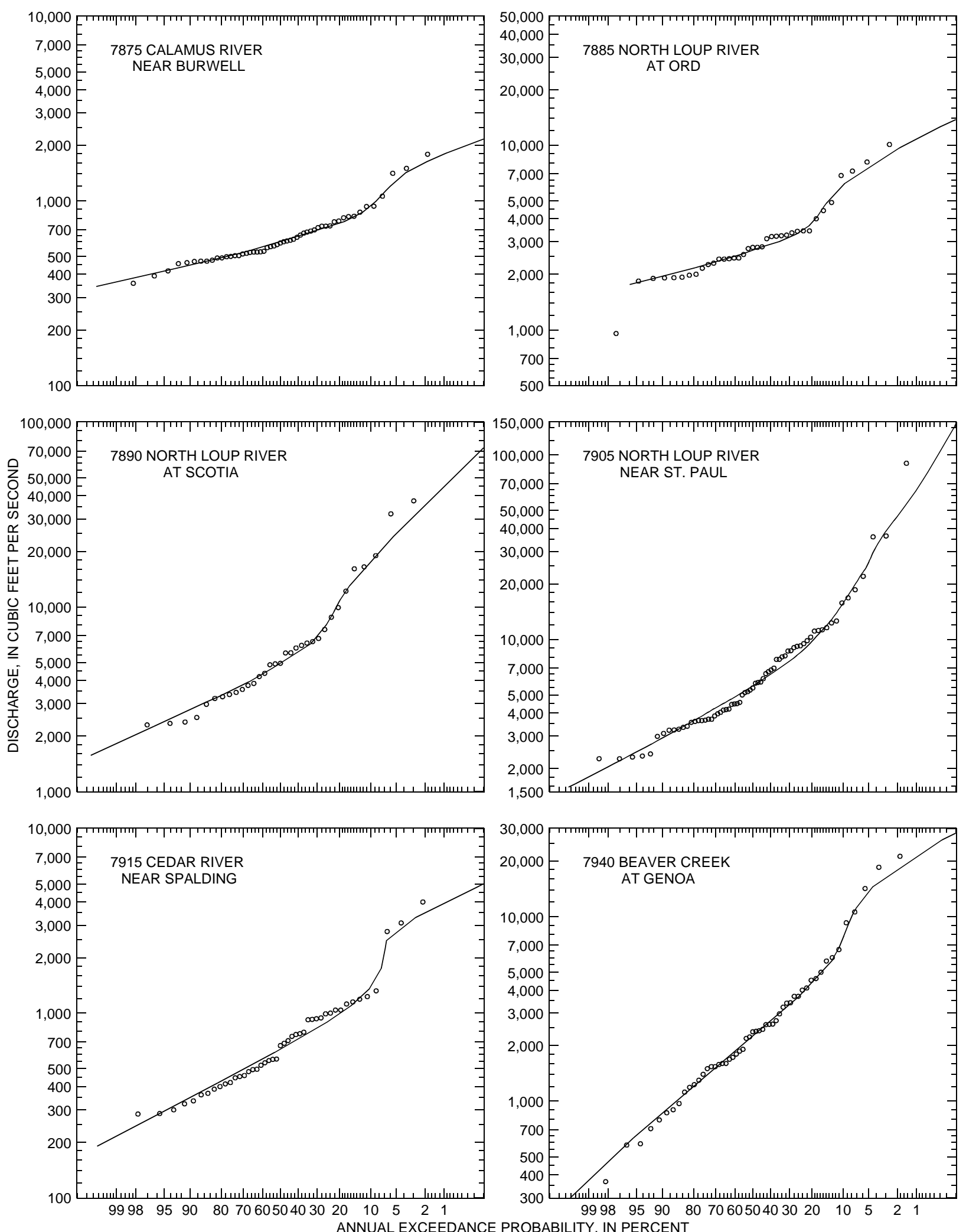
EXPLANATION ANNUAL EXCEEDANCE PROBABILITY, IN PERCENT

Composite frequency curve

- Annual maximum peak flow

Figure C3. Composite peak-flow frequency curves for selected Nebraska streamflow-gaging stations in the Platte River Basin with average soil permeability of the top 60 inches of more than 4 inches per hour.

\section{C-4 Peak-Flow Frequency Relations and Evaluation of the Peak-Flow Gaging Network in Nebraska}



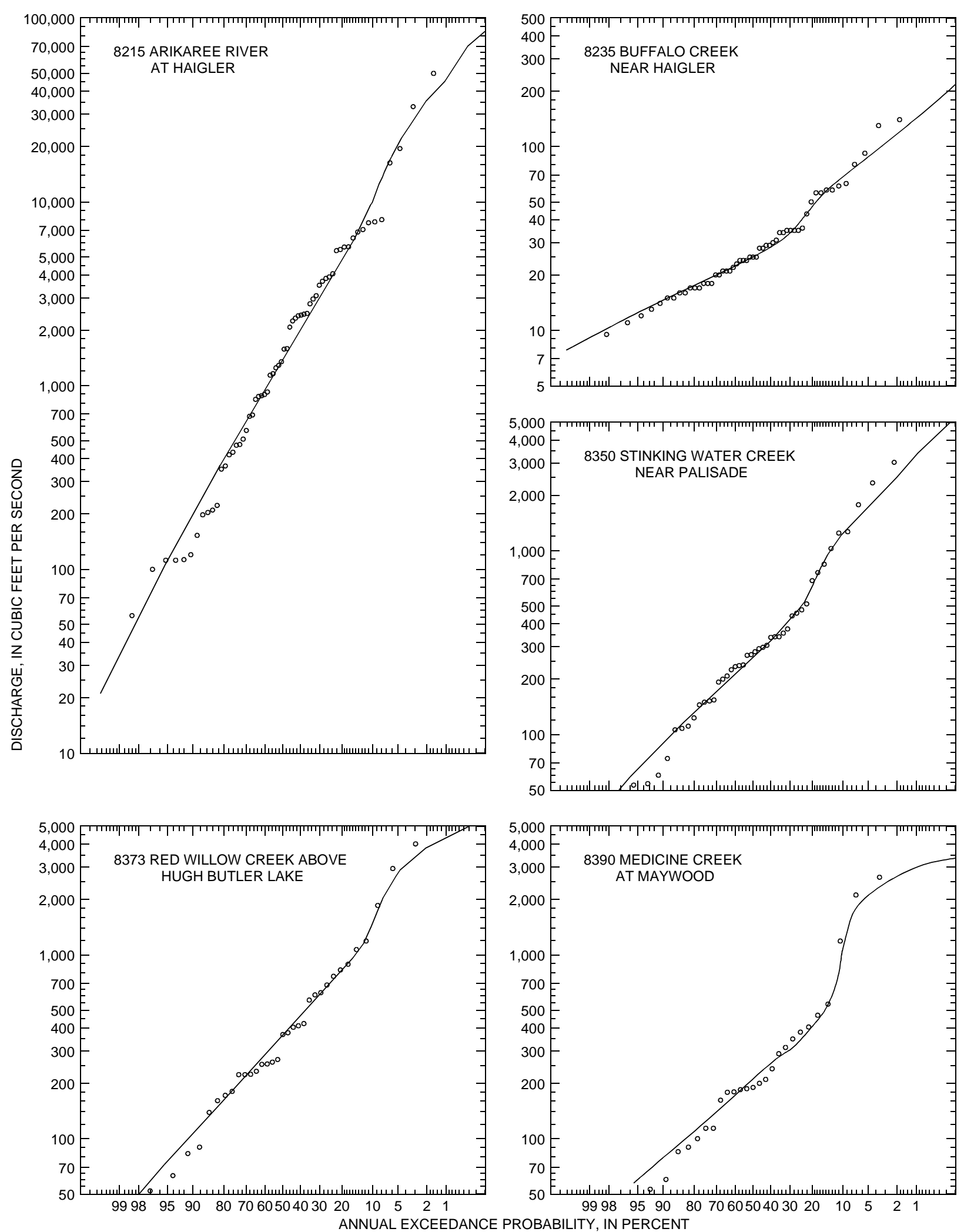

EXPLANATION

$$
\text { Composite frequency curve } \quad \circ \quad \text { Annual maximum peak flow }
$$

Figure C4. Composite peak-flow frequency curves for selected Nebraska streamflow-gaging stations in the Republican River Basin with average soil permeability of the top 60 inches of more than 4 inches per hour. 